\title{
Xiong Shili's Understanding of Reality and Function, 1920-1937
}

\author{
Yu Sang
}

桑雨
A thesis submitted for the degree of Doctor of Philosophy of The Australian National University

August 2018 


\section{Thesis Declaration}

I hereby declare that I am the sole author of this thesis and that not any part of this thesis has been submitted for any other degree or diploma at any other university or education institution. I also confirm that any materials from other people's writings included in this thesis have been indicated, and due acknowledgement has been given to the work of others.

Signed:

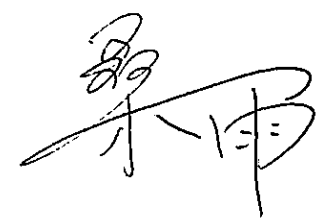

Yu Sang

Date: $12 / 08 / 2018$ 


\section{Acknowledgements}

First of all, I would like to express my sincere gratitude to my primary supervisor Prof. John Makeham, for his guidance, patience, and support throughout the several years of my PhD study. His immense knowledge and constructive feedback on my drafts of this thesis have greatly benefited me, and his encouragement had given me the confidence to continue my study. Without his supervision and help, it would have been impossible for me to complete this thesis. Indeed, I feel very lucky to have John as my supervisor. I would also like to deeply thank Dr. Mark Strange, another supervisor who has continuously supported my study throughout these years. In writing this thesis, Mark has provided me with many valuable opinions and suggestions, which have not only helped me with this study, but also broadened my mind from various perspectives. His rigorous approach to research has also influenced my style of research. My gratitude also goes to other members on my supervisory panel: Dr. John Jorgensen, who read my thesis and offered very useful comments in the final stage of my study; and Prof. John Powers, whose insightful suggestions played an important role in my thesis planning and writing during the first three years of my study.

Besides, I would like to express my appreciation to all the other people who have helped me during my PhD study. I thank Dr. Nathan Woolley for reading my writing and teaching me many writing skills in the early stages of my study. I also thank Darrell Dorrington, Maxine McArthur, Serena Beresford-Wylie, and others, for proofreading my chapters and refining the language in them. I have learnt a lot from these people about how to structure a thesis and how to express my ideas in English more effectively. My thanks extend to Xueqing Zhong and many other friends, for their company, support, and encouragement, for the free exchange of ideas we have had on how to solve problems, and for the many days we were writing together. Many thanks also go to other people who I have not mentioned here by 
name but who have inspired me and helped me in various ways. In addition, I would like to thank the Australian National University for granting me the Australian Postgraduate Award for my PhD program and providing me with a good working environment and facilities.

Last but not the least, I am deeply indebted to my family. I am truly grateful to my parents and parents-in-law for their understanding and blessing. I greatly appreciate my husband, Xianglei Wang, for everything he has done for me, and especially for taking on almost all household duties during the final stages of my study, so that I could concentrate on writing my thesis. I thank my baby daughter, Emma, for bringing me joy and being a ray of sunshine when I was frustrated with my thesis. I also thank my dog, Lucky, and cat, Dido, for keeping me company while I worked late at night. The love and support from my family is a bedrock on which I have been able to complete this thesis. 


\begin{abstract}
Xiong Shili 熊十力 (1885-1968) was one of the most influential Chinese philosophers of the twentieth century, and he made a major contribution to the development of both Confucian and Buddhist thought. He is generally considered to be a founding figure of New Confucianism, and had a great influence on later New Confucians.
\end{abstract}

Xiong's metaphysics focuses mainly on the concepts of Reality ( $t i$ 體) and Function (yong 用). This pair of concepts is one of the key conceptual polarities in traditional Chinese philosophy. Generally speaking, Reality refers to the ontological realm, the intrinsic reality of things, while Function refers to the phenomenal world, the external manifestation of things. There have been many Chinese thinkers in Chinese philosophical history who contributed to the understanding and interpretation of this pair of concepts. Xiong developed his understanding of Reality and Function drawing on traditional accounts of the ti-yong polarity.

This thesis is a study in the intellectual history of modern Chinese philosophy. Xiong's mature ti-yong philosophical system was established and consolidated in the 1930s, with its early formative process beginning in 1920. Clarifying this process of development can help us understand Xiong's overall philosophical development more accurately. Scholars have tended to focus on the mature stage of Xiong's philosophy while overlooking how it was developed over an extended period. In contrast, my study examines Xiong's understanding of Reality and Function between 1920 and 1937. It pays particular attention to how his thought changed and developed over this period, and also to the sources on which he drew to elucidate his ideas. This study will provide a more comprehensive basis for studies on the later periods of Xiong's philosophical thought. Given Xiong's important status in the modern New Confucian school, while contributing to a fuller understanding of Xiong's metaphysics, this study also contributes to our understanding of New Confucian philosophy and its early development. 


\section{Table of Contents}

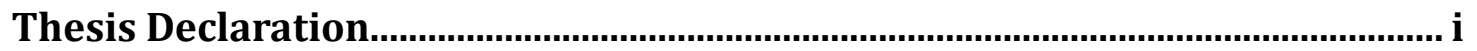

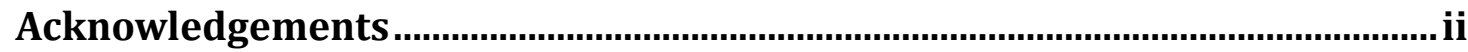

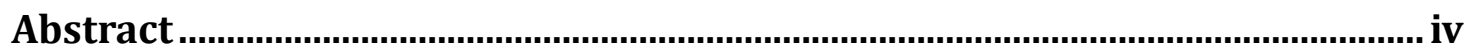

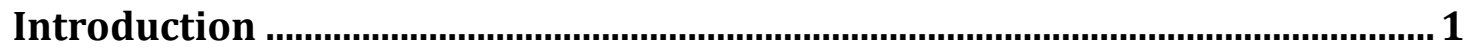

Xiong's Life and Thought, 1885-1920 ........................................................................

Xiong's Life and Thought, 1920-1937 ........................................................................10

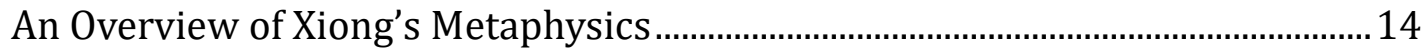

Objectives and Methods of the Study....................................................................... 17

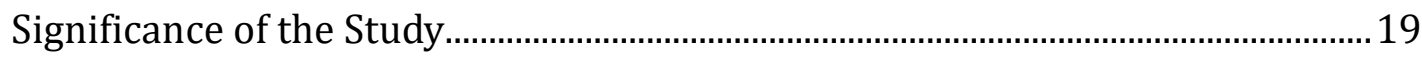

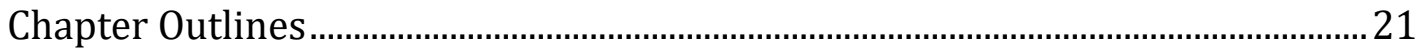

Chapter One - The Philosophical Background to the Development of

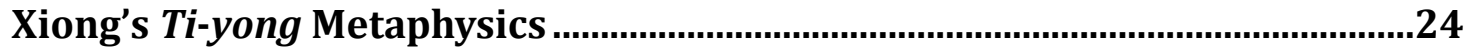

1.1 The Formation and Development of the Ti-yong Conceptual Polarity in

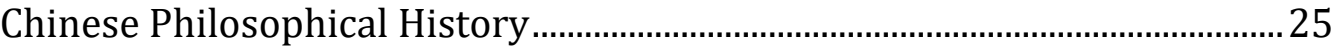

1.1.1 Buddhist Discussions on Reality and Function.........................................30

1.1.2 Reality and Function in Neo-Confucianism ..............................................4 42

1.2 Xiong's Reflections on the Ontological and the Phenomenal before 1920.. 54

1.3 A Dispute Concerning Reality and Function in the Early Twentieth

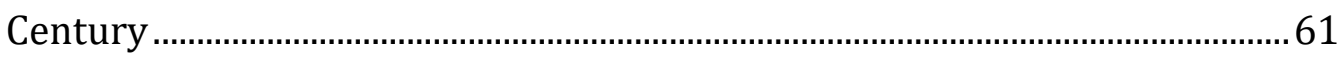

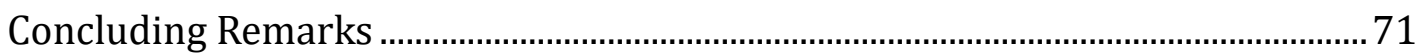

\section{Chapter Two - Xiong's Two-level Ti-yong System between 1920 and}

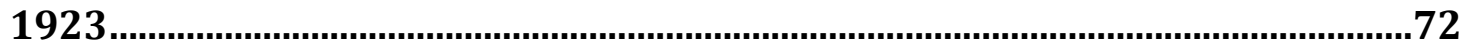

2.1 Level 1: Suchness as Reality and Consciousness as Function..........................77

2.1.1 Consciousness as the Representation of the Phenomenal World.......... 77

2.1.2 The Characteristics of Consciousness.............................................................91

2.1.3 Xiong's Negation of the Existence of Consciousness.................................96

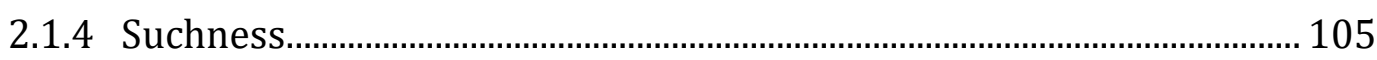

2.1.5 The Relationship between Suchness and Consciousness ..................... 108 
2.2 Level 2: Productive Power as Reality and Manifest Activity as Function 115

2.2.1 Productive Power 115

2.2.2 Manifest Activity. 119

2.2.3 The Relationship between Productive Power and Manifest Activity 120

2.3 The Influence of Ouyang Jingwu's Ti-yong Perspective.................................. 126

Concluding Remarks 130

Chapter Three - The Modification of Xiong's Conception of Reality and Function between 1923 and 1927 135

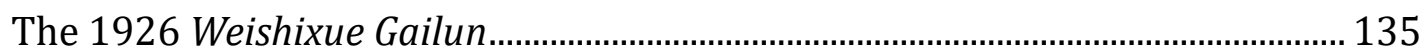

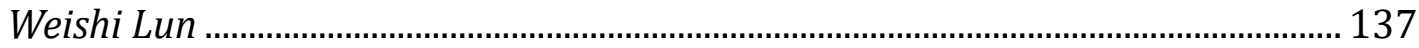

The Structure and Main Arguments of this Chapter ............................................. 138

3.1 Xiong's Understanding of Ti-yong in the 1926 Weishixue Gailun ................. 140

3.1.1 Xiong's Critique of the Yogācāra Theories on Consciousness and Productive Power 140

3.1.2 Xiong's Reconstruction of the Yogācāra Concept of Transformation 150

3.1.3 Ontological Reality, Its Function, and Their Relationship..................... 167

3.2 Xiong's Understanding of Ti-yong in His Weishi Lun ...................................... 176

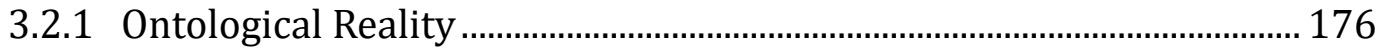

3.2.2 The Relationship between Ontological Reality and Function .............. 182

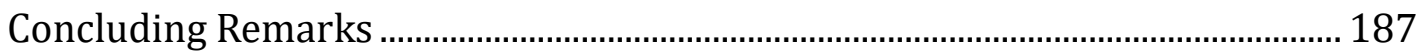
Appendix: A Clarification of the Period Xiong Composed the Weishi Lun......... 190

Chapter Four - The Development of Xiong's Conception of Reality and

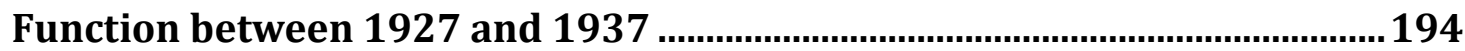

4.1 Whether or Not Sentient Beings Share the Same Reality ……...................... 197

4.2 The Development of Xiong's Understanding of Reality.................................. 206

4.2.1 Xiong's Identification of the Mind with Reality....................................... 206

4.2.2 Simultaneous Transformation and Constancy as a Characteristic of

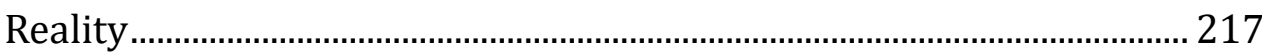

4.3 The Relationship between Reality and Function ............................................ 227

4.3.1 It is Precisely Function That is Reality ................................................... 227

4.3.2 Revealing Reality through Function ........................................................... 234

4.3.3 Undifferentiated Reality Permeates the Entire Phenomenal World.. 238 Concluding Remarks .............................................................................................. 245 
A Review of Xiong's Changing Understanding of Reality and Function between

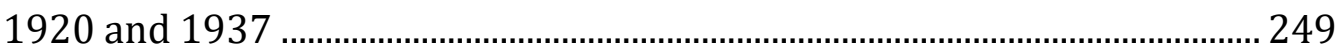

Why is Xiong's Philosophy of Reality and Function Unique? ................................ 252

Why did Xiong Continue to Modify and Develop His Conception of Reality and

Function?

Works Cited. 262 


\section{Introduction}

Xiong Shili 熊十力 (1885-1968) is widely regarded as one of the most influential Chinese philosophers of the twentieth century. His important position in Chinese philosophical history can be summarised as follows. First, he was an innovative philosopher who created a comprehensive philosophical system. As John Makeham relates, Xiong has been described as "perhaps the most creative philosopher within Modern New Confucianism", and "few could match him when it comes to building his own distinctive comprehensive philosophical system". ${ }^{1}$ Also, Jana S. Rošker describes Xiong as "one of the first Chinese philosophers, who developed his own system of thought, which was based upon classical Confucian concepts and, at the same time, adjusted to the conditions of the New Era". 2 Second, Xiong's philosophical system drew strongly on elements drawn from traditional Chinese philosophy. According to Chen Lai 陳來, Xiong's metaphysics, in terms of its inheritance and development of traditional Chinese philosophy, was widely acknowledged by his contemporaries as the most distinctive and successful philosophical system. ${ }^{3}$ Third, Xiong is generally considered to be a founding figure of New Confucianism and had an immense influence on later New Confucians. ${ }^{4}$

\footnotetext{
${ }^{1}$ John Makeham (trans. and annot.), New Treatise on the Uniqueness of Consciousness, New Haven \& London: Yale University Press, 2015, p. xi. See also the related assessments of other scholars cited in ibid., pp. xi-xii.

2 Jana S. Rošker, "Modern Confucian Synthesis of Qualitative and Quantitative Knowledge: Xiong Shili 熊十力”, Journal of Chinese Philosophy, vol. 36, no. 3, 2009, p. 376.

${ }^{3}$ Chen Lai 陳來, “Xiong Shili yu xiandai xin rujia de 'zhexue' guannian” 熊十力與現代新儒家的 “哲學” 觀念 (Xiong Shili and the concept of "philosophy” in modern New Confucianism), in his Xiandai Zhongguo zhexue de zhuixun: xin lixue yu xin xinxue 現代中國哲學的追尋: 新理學與新心學 (The pursuit of modern Chinese philosophy: New Principle-centred Learning and New Mindcentred Learning), Beijing: Shenghuo dushu xinzhi sanlian shudian, 2010, p. 23.

4 According to John Makeham, "New Confucianism is a modern neo-conservative philosophical movement, with religious overtones. Proponents claim it to be the legitimate transmitter and representative of orthodox $r u$ 儒 (Confucian) values. The movement is promoted and/or researched by prominent Chinese intellectuals based in China, Taiwan, Hong Kong, and the United States of America". He further cautions, however, that "although most of the promoters and
} 
Tang Junyi 唐君毅 (1909-1978), Xu Fuguan 徐復觀 (1903-1982), and Mou Zongsan 牟宗三 (1909-1995) - all representatives of the so-called "second generation of New Confucianism" - were Xiong's students whom he inspired and guided. As a result, the twentieth-century historian of Chinese philosophy, Wingtsit Chan (1901-1994), even stated that Xiong "has influenced more young Chinese philosophers than any other contemporary Chinese philosopher". ${ }^{5}$

\section{Xiong's Life and Thought, 1885-1920}

The period between 1885 and 1920 can be considered a preparatory stage for Xiong's establishment of his philosophical system. Xiong's experiences during this period can roughly be divided into two aspects: his revolutionary activities and his intellectual development, which will be introduced briefly in what follows.

By the late nineteenth century, China was beset by a wide range of social, economic, political, and military problems, stimulating patriotism and fomenting aspirations for revolution. During the first decade of the twentieth century, Xiong participated enthusiastically in the revolutionary activities and political affairs of the time. As he recollected in his later writings, he joined the Daily Understanding Society (Ri zhi hui 日知會) at its establishment in 1905. This was an organisation established in Wuchang 武昌, Hubei, by such revolutionaries as Liu Jing'an 劉靜庵 (1875-1911). In 1906, Xiong and several other revolutionaries also jointly established the Huanggang Military and Educational Lecture Society (Huanggang junxuejie jiangxishe 黃岡軍學界講習社), with the aim of contacting other

\footnotetext{
sympathetic interpreters of New Confucianism trace the movement to the early part of the twentieth century, in fact, there is little evidence that New Confucianism had attained a degree of integration or coalescence sufficient for it to be recognised and promoted as a distinct philosophical movement, or school of thought, before the 1970s". John Makeham, Lost Soul: "Confucianism" in Contemporary Chinese Academic Discourse, Cambridge, Mass.: Harvard University Asia Centre, 2008, p. 2, note 2. 5 Wing-tsit Chan, A Source Book in Chinese Philosophy, Princeton, NJ: Princeton University Press, 1963, p. 765.
} 
revolutionaries. ${ }^{6}$

At the same time as this active involvement in revolutionary activities, however, Xiong came into contact with traditional Chinese philosophy. In fact, he had already received classical training during his childhood: he claimed to have memorised traditional Chinese texts, such as the Si shu 四書 (The four books). ${ }^{7}$ He had received instruction in these works from his father, Xiong Qixiang 熊其相 (?-?), a literate man accomplished in the Cheng-Zhu 程朱 school of NeoConfucianism, ${ }^{8}$ and also from He Shengmu 何聖木 (?-?), a friend of his father's and a teacher who also held the Cheng-Zhu school of Neo-Confucianism in esteem. ${ }^{9}$ The classical training Xiong received in his childhood laid a solid foundation for his

\footnotetext{
${ }^{6}$ See Xiong Shili 熊十力, “Wang Han zhuan” 王漢傳 (A biography of Wang Han), Shili yuyao 十力 語要 (Selected letters and talks of Xiong Shili), in Xiong Shili quanji 熊十力全集 (The complete writings of Xiong Shili), Wuhan: Hubei jiaoyu chubanshe, 2001, vol. 4, p. 155; “He Zixin zhuan” 何 自新傳 (A biography of He Zixin), ibid., pp. 159-160. For Xiong's other revolutionary activities during the first decade of the twentieth century, see, for example: Cai Renhou 蔡仁厚, Xiong Shili xiansheng xuexing nianbiao 熊十力先生學行年表 (A chronology of Mr. Xiong Shili's learning and deeds), Taibei: Mingwen shuju, 1991, pp. 10-12; Ding Weixiang 丁爲祥, Xiong Shili xueshu sixiang pingzhuan 熊十力学术思想評傳 (A critical biography of Xiong Shili's academic thought), Beijing: Beijing tushuguan chubanshe, 1999, pp. 13-14, 337-338; and Song Zhiming 宋志明, Xiong Shili pingzhuan 熊十力評傳 (A critical biography of Xiong Shili), Nanchang: Baihuazhou wenyi chubanshe, 2010, pp. 7-8, 203-204.

7 I.e. Lunyu 論語 (The analects of Confucius), Daxue 大學 (Greatlearning), Zhongyong 中庸 (The doctrine of the mean), and Mengzi 孟子 (The book of Mencius).

8 According to Peter K. Bol, Neo-Confucianism is a "school of thought built on the teachings of eleventh-century moral philosophers and an elite social movement that took shape in the twelfth century. ... It is a kind of Confucianism, but one that claims to be rediscovering what Confucius and Mencius really meant and that often speaks through its interpretations of the ancient texts. ... Some modern scholars hold that it gave traditional ethics a new philosophical foundation by co-opting basic concepts from Buddhism and Daoism, although the first Neo-Confucians thought they were making Buddhism and Daoism unnecessary. It was the orthodoxy of the late imperial system and for that reason was condemned by those seeking to create a modern nation-state". See Peter K. Bol, Neo-Confucianism in History, Cambridge: Harvard University Press, 2008, p. 1. The Cheng-Zhu school of Neo-Confucianism refers to the faction of Neo-Confucianism that followed the thought of the Northern Song (960-1127) Neo-Confucians Cheng Hao 程影 (1032-1085) and Cheng Yi 程頣 (1033-1107) and which took the Southern Song (1127-1279) Neo-Confucian Zhu Xi 朱喜 (1130$1200)$ as its most representative figure.

9 See Xiong, “Li Dixuan jiyu” 黎條玄記語 (Record by Li Dixuan), Shili yuyao, p. 424. See also: Cai, Xiong Shili xiansheng xuexing nianbiao, p. 8; Ding, Xiong Shili xueshu sixiang pingzhuan, pp. 7-11.
} 
later studies of traditional Chinese philosophy.

Perhaps because of the ingrained influence of Xiong Qixiang and He Shengmu, in the first decade of the twentieth century, Xiong seems to have had a preference for the works of Neo-Confucian thinkers. Xiong related that he read the works of the Ming (1368-1644) Neo-Confucian Chen Baisha 陳白沙 (1428-1500) when he was sixteen or seventeen years old; he was especially fond of Chen's "Qinshou shuo" 禽獸說 (An essay on birds and beasts). ${ }^{10}$ He also read the works of the late Ming (1368-1644) and early Qing (1644-1912) thinker Wang Fuzhi 王夫之 (16191692), which, according to Xiong himself, inspired his revolutionary aspirations. ${ }^{11}$ As Stephen R. Platt has demonstrated, Wang Fuzhi was a Ming loyalist, defiant of the Manchus who had usurped the throne and were contemptuous of the Chinese who served as officials in their Qing dynasty, and his defiance and contempt were deeply embedded in his scholarship. Also, Wang was extremely worried about the afflictions of the common people, and he tried to bring the practical affairs of the world to order. ${ }^{12}$ Wang's life experiences and revolutionary ideologies are likely to have shaped Xiong's own revolutionary thinking. Indeed, when Xiong organised the Huanggang Military and Educational Lecture Society in 1906, he and other members of the Society gave weekly talks on nationalism and democracy for which one of the main sources was Wang Fuzhi's thought. ${ }^{13}$

Among the works of Neo-Confucians, Xiong paid particular attention to those on Zhouyi 周易/Yijing 易經 (The book of change). ${ }^{14}$ According to Ding Weixiang

\footnotetext{
10 Xiong, “Chen Baisha xiansheng jinian” 陳白沙先生紀念 (In commemoration of Mr. Chen Baisha), Shili yиуао chuхu 十力語要初續 (The first sequel to Selected Letters and Talks of Xiong Shili), in Xiong Shili quanji, vol. 5, pp. 279-280.

11 Xiong, "Li Dixuan jiyu”, p. 425. See also: Cai, Xiong Shili xiansheng xuexing nianbiao, p. 9; Song, Xiong Shili pingzhuan, pp. 5-6, 203.

12 See Stephen R. Platt, Provincial Patriots: The Hunanese and Modern China, Cambridge, Mass.: Harvard University Press, 2007, pp. 8-33.

13 See Guo Qiyong 郭齊勇, Xiong Shili zhexue yanjiu 熊十力哲學研究 (A study on Xiong Shili's philosophy), Beijing: Renmin chubanshe, 2011, p. 4; Ye Xian'en 葉賢恩, Xiong Shili zhuan 熊十力傳 (A biography of Xiong Shili), Wuhan: Hubei renmin chubanshe, 2010, p. 53.

14 Zhouyi, or Yijing, is one of the most influential Chinese classics.
} 
丁爲祥, in the second half of the first decade of the twentieth century, Xiong studied the likes of Wang Fuzhi's Zhouyi neizhuan 周易內傳 (Explanation of the Book of Change) and Zhouyi waizhuan 周易外傳 (An extended interpretation of the Book of Change); the Northern Song (960-1127) Neo-Confucian Cheng Yi's 程頣 (10331107) Zhouyi Chengshi zhuan 周易程氏傳 (Cheng Yi's annotation of the Book of Change); and Jin si lu 近思錄 (A record of reflection on things at hand) by the Southern Song (1127-1279) Neo-Confucians Zhu Xi 朱喜 (1130-1200) and Lü Zuqian 呂祖謙 (1137-1181). Xiong compared the strengths and weaknesses of different studies of Zhouyi and also discussed with his friend, the revolutionary He Zixin 何自新 (1881-1910) such concepts as yin 陰 and yang 陽, qian 乾 and kun 坤, movement (dong 動) and quiescence (jing 靜). ${ }^{15}$ Xiong's interest in Zhouyi was also shared with Wang Han 王漢 (1884-1905), a good friend since adolescence. Wang had studied Zhouyi when he was young and was extremely fond of it. In his biography of Wang Han, Xiong recorded at great length the discussions that he and Wang had on Zhouyi. ${ }^{16}$

By the second decade of the twentieth century, Xiong had become increasingly disillusioned by revolutionaries' contests for power and profit, as well as the ensuing political chaos. In 1913, for example, he criticised the incumbent government as ignorant and incompetent, selfish and arbitrary, and he predicted its imminent demise. ${ }^{17}$ Although he participated in the Constitutional Protection Movement (Hufa yundong 護法運動), led by Sun Yat-sen (Sun Zhongshan 孫中山, 1866-1925) between 1917 and 1918 to oppose the dictatorship of the Northern warlords (Beiyang junfa 北洋軍閥), Xiong felt: “There is definitely no revolutionary among us who exerts effort in moral cultivation, so how will they ever set things right?" (吾黨人絕無在身心上作工夫者, 如何撥亂反正? ) ${ }^{18}$ Xiong therefore

\footnotetext{
15 See Ding, Xiong Shili xueshu sixiang pingzhuan, pp. 19-20, 338.

16 See Xiong, “Wang Han zhuan”, pp. 153-154.

17 Xiong, “Fu Wu Guanyin (kuichou)” 復吳貫因（癸丑） (Reply to Wu Guanyin [1913]), Xin shu

心書 (Book of mind), in Xiong Shili quanji, vol. 1, p. 20.

18 Xiong, "Li Dixuan jiyu”, p. 425.
} 
gradually ended his involvement in social movements and instead committed himself to study and scholarship. In this, he was like a number of his contemporaries, who had come to realise that there were social problems that revolutionaries could not solve but which intellectuals might. ${ }^{19}$ Xiong recorded his transition in one of his later writings:

吾年十六七, 便以革命從戎, 狂野不學。三十左右, 因奔走西南, 念 黨人競權爭利, 革命終無善果, 又目擊萬裏朱殷, 時或獨自登高, 蒼 茫望天, 淚盈盈雨下, 以爲禍亂起於眾昏無知, 欲專力於學術, 導人 群以正見。自是不作革命行動, 而虛心探中印兩方之學。20

When I was sixteen or seventeen years old, I was wild and did not study on account of revolution and enlisting in the army. When I was around thirty, because I had been knocking around the Southwest, I became mindful that the revolutionaries were contending for power and profit, and that the revolution would ultimately come to no good end. I also saw "the thousands of miles of blood" with my own eyes. ${ }^{21}$ I occasionally ascended a height by myself and, looking at the boundless sky, cried profusely. I considered that calamity and chaos arose from the confusion and ignorance of the masses, [so] I wanted to focus my energies on scholarship and guide people with correct views. From then on, I did not participate in revolutionary activities but explored

\footnotetext{
19 For example, Xiong's friend Zhang Zhongru 張仲如 (1871-1955) believed that transforming political power (ge zheng 革政) was not as good as transforming the mind (ge xin 革心). For Zhang, to transform the mind would be to change Confucianism's influence on Chinese people. See Xiong, “Zhang Chunyi cungao xu” 張純一存莕序 (Preface to Zhang Chunyi's Manuscripts), Xin shu, pp. 7-8. 20 Xiong, "Yu zhi Feiwu” 與侄非武 (To my nephew Feiwu), Zun wen lu 尊聞錄 (Record of what has been respectfully heard), in Xiong Shili quanji, vol. 1, p. 659.

21 The phrase “thousands of miles of blood" (wanli zhuyin 萬裏朱殷) comes from the eighthcentury prose poem “Diao gu zhanchang wen” 吊古戰場文 (Lament at an ancient battle field), by the Tang (618-907) literatus Li Hua 李華 (715-766). In it, Li describes the calamity of war. See Li Hua 李華, “Diao gu zhanchang wen” 古古戰場文 (Lament at an ancient battle field), in Guwen guanzhi 古文觀止 (The finest of ancient prose), eds. Wu Chucai 吳楚材 and Wu Diaohou 吳調侯, Beijing: Zhongguo wenshi chubanshe, 2003, pp. 388-392.
} 
both Chinese and Indian learning with an open mind.

Accordingly, the initial reason for Xiong's transition from revolution to scholarship was his intention to take a new approach to save the nation and people.

While gradually ceasing his involvement in social movements during the second decade of the twentieth century, Xiong began to publish articles to express his thoughts on traditional Chinese philosophy. In 1913, he published five essays in Yongyan 庸言 (Trite remarks), a magazine founded by the leading thinker and statesman Liang Qichao 梁啓超 (1873-1929). ${ }^{22}$ These essays further demonstrate Xiong's admiration for Zhouyi and Neo-Confucian thinkers. Especially, he considered the eleventh-century thinkers Zhou Dunyi 周敦頣 (1017-1070) and Zhang Zai 張載 (1020-1077), as well as Wang Fuzhi, to be sages (shengren 聖 人). ${ }^{23}$ Above all, Xiong emphasised Neo-Confucianism's and Zhouyi's detailed attention to human affairs, a point of focus consistent with his concern about the Chinese nation and people at the time.

In these five essays of 1913, Xiong also discussed several Buddhist ideas. He criticised Buddhism mainly for its concept of emptiness (kong 空; śūnyatā). For Xiong, because Buddhism believes that the myriad things in the universe are empty of self-nature (zixing 自性; svabhāva), it seeks to disengage itself from the world and pursue what it calls "neither arising nor ceasing" (bu sheng bu mie 不生不滅). Based on this understanding of Buddhism, Xiong believed that Buddhist doctrines were divorced from human affairs and caused people to lose their moral principles. ${ }^{24}$ If we also consider Xiong's concern about the nation and people at

\footnotetext{
22 The essays are: "Zheng ren xuehui qi” 證人學會啓 (A letter to the Society for Proving Why Humans are Human); “Da He Zixin shu” 答何自新書 (A letter of reply to He Zixin); “Jian'an suibi” 健庵隨筆 (An essay in Jian'an); “Jian’an suibi (xu)”健庵隨筆 (續) (An essay in Jian'an [continuation]); and "Yi jing lu xuyan" 翊經錄緒言 (An introduction to The Record of Assisting the Classics). They appear in Xiong Shili quanji, vol. 8, pp. 1-23.

${ }^{23}$ Xiong, "Yi jing lu xuyan" 翊經錄緒言 (An introduction to The Record of Assisting the Classics), in Xiong Shili quanji, vol. 8, p. 23.

${ }^{24}$ Xiong, “Da He Zixin shu” 答何自新書 (A letter of reply to He Zixin), ibid., p. 8; “Jian'an suibi” 健 庵隨筆 (An essay in Jian'an), ibid., pp. 9, 12.
} 
that time, it is obvious that his dissatisfaction with Buddhism was closely related to his judgement that it is indifferent to social problems and so appeared to offer few solutions to the national crisis. However, it can be seen from Xiong's simplistic interpretations of Buddhism at this time that he had yet to develop an informed understanding of it, and that his strong involvement in social movements may have prevented him from acquiring a proper understanding of Buddhist thought.

In 1918, Xiong published his Xin shu 心書 (Book of mind), a collection of twenty-five articles that include reading notes, letters, biographies, and random thoughts. In the main, this collection conveyed Xiong's profound concern for social problems through discussions of the social effects of various ideas in traditional Chinese culture and the behavious of certain figures in Chinese history. As the contemporary scholar Jing Haifeng 景海峰 points out, Xin shu reflects the social darkness in China after the 1911 Revolution and the depressed mood of contemporary Chinese intellectuals, as well as Xiong's responses to his own revolutionary experiences. ${ }^{25}$

It is worth noting that, by Xin shu, Xiong's views on Buddhism had changed from those expressed in his 1913 essays. He had now come to hold a very positive attitude towards Buddhism: "Buddhism is the most refined among those which have talked about philosophic theories in ancient or modern times" (古今言哲理 者, 最精莫如佛). ${ }^{26}$ Correspondingly, he endorsed Buddhist theories in many parts of his 1918 collection. ${ }^{27}$ There even are two articles in which he made virtually no comment himself, but merely cited other scholars' writings about Buddhist ideas. ${ }^{28}$

\footnotetext{
25 Jing Haifeng 景海峰, Xiong Shili zhexue yanjiu 熊十力哲學研究 (A study on Xiong Shili's philosophy), Beijing: Beijing daxue chubanshe, 2010, pp. 53-56.

${ }^{26}$ Xiong, “Wenjin xuehui qi” 問津學會啓 (A letter to the Society for Making Inquiries), Xin shu, p. 23.

27 See, for example, Xiong, "Yu Zhang Suwu” 與張素武 (To Zhang Suwu), ibid., p. 27; “Zhang Yichen Li Zhuan yishi” 張翊辰李專遺事 (The story of Zhang Yichen and Li Zhuan), ibid., p. 33.

28 See Xiong, “Fu Zhangjun” 復張君 (Reply to Mr. Zhang), ibid., pp. 9-11; “Ji Liangjun shuo Lupang boshi zhi xueshuo” 記梁君說魯浐博士之學說 (Record of Mr. Liang's discussions on Doctor Le Bon's doctrines), ibid., pp. 25-26.
} 
This suggests that Xiong's understanding of Buddhism was still not deep enough to provide an in-depth analysis of his own, and that his discussions of Buddhism remained mediated by other scholars' views.

It also appears from Xin shu that Xiong had come to be influenced by such contemporary intellectuals as Zhang Taiyan 章太炎 (1869-1936). In an article in Xin shu that discusses Wang Fuzhi, for example, Xiong related that he had once been fond of Wang Fuzhi's teachings but, on reading Zhang Taiyan's “Jianli zongjiao lun” 建立宗教論 (On founding a religion), he had begun to delve into Indian Buddhism and had subsequently found Wang's thought to be shallow. ${ }^{29}$ Xiong also quoted repeatedly from Zhang Taiyan's writings; one article in Xin shu is basically a citation from Zhang's “Dasheng fojiao yuanqi kao” 大乘佛教緣起考 (An investigation into the doctrine of dependent origination in Mahāyāna Buddhism)..$^{30}$ As Viren Murthy has shown, Zhang Taiyan's Buddhist ideas were combined with his revolutionary activities, and Zhang merged his religious goal of the liberation of sentient beings with national liberation. ${ }^{31}$ It is possible that the political relevance of Buddhism in Zhang's writings caused Xiong to accept Zhang's Buddhist ideas and also to change his own views on Buddhism from criticism to appreciation. ${ }^{32}$ Zhang's strong interest in, and writings on, Yogācāra may also have contributed to Xiong's interest in Indian Buddhism in the latter half of the 1910s. ${ }^{33}$

\footnotetext{
${ }^{29}$ Xiong, “Chuanshanxue ziji” 船山學自記 (Personal note on Wang Chuanshan’s learning), ibid., p. 6.

30 See Xiong, "Fu Zhangjun”, pp. 9-11.

31 Viren Murthy, The Political Philosophy of Zhang Taiyan: The Resistance of Consciousness, Leiden: Brill, 2011, p. 131. On this point, see also Jiang Canteng 江燦騰, “Lü Cheng yu Xiong Shili lunxue hangao pingyi” 呂澂與熊十力論學函稿評議 (A discussion on the scholarly correspondence between Lü Cheng and Xiong Shili), in Xiong Shili quanji, supplementary volume A, p. 435.

32 On the matter of Zhang Taiyan's influence on Xiong's early period, see also ibid., pp. 437-438.

33 Yogācāra is an influential school of Indian Buddhism. For a study of Zhang Taiyan's interpretation of Yogācāra doctrines, see John Makeham, "Zhang Taiyan, Yogācāra Buddhism, and Chinese Philosophy", in Learning to Emulate the Wise: The Genesis of Chinese Philosophy as an Academic Discipline in Twentieth-Century China, ed. John Makeham, Hong Kong: Chinese University Press, 2012, pp. 103-128.
} 
Above all, although Xiong's intellectual development between 1885 and 1920 was linked inextricably with his concern over contemporary social and political problems, the studies of traditional philosophical ideas that he made during this early period provided important intellectual resources on which he continued to draw throughout his life.

\section{Xiong's Life and Thought, 1920-1937}

Unlike the period from 1885 to 1920 , between 1920 and 1937 Xiong entered a relatively stable phase of his life, during which he was able to concentrate his attention on philosophical studies. In 1920, Xiong began his life of philosophical studies officially by entering the China Institute of Inner Learning (Zhina neixue yuan 支那內學院) in Nanjing. ${ }^{34}$ He was influenced in his decision by his contemporary, Liang Shuming 梁漱溟 (1893-1988). In 1916, Liang published an essay entitled “Jiu yuan jue yi lun" 究元決疑論 (A study on exploring the origin and resolving doubts) in Dongfang zazhi 東方雜誌 (Eastern miscellany). In that essay, Liang criticised Xiong's 1913 comments about Buddhism. ${ }^{35}$ Xiong had not noticed Liang's essay when it was first published, but read it and replied to Liang three years later: according to Liang, in 1919 Xiong sent him a postcard in which he acknowledged Liang's criticism and expressed the hope to have a discussion with Liang. After they met, they talked about Buddhist teachings and became good friends. The immediate result of this conversation was that Liang persuaded Xiong to study Buddhism and Xiong agreed. In the summer of 1920, Liang went to the China Institute of Inner Learning in Nanjing to visit the Institute's founder and Yogācāra scholar Ouyang Jingwu 歐陽竟無 (1871-1943). Liang introduced Xiong

\footnotetext{
34 The China Institute of Inner Learning was founded in 1922 but had been running informally since 1918, based on the grounds of the Jinling Sutra Press (Jinling ke jing chu 金陵刻經處). See John Makeham, "Xiong Shili's Critique of Yogācāra Thought in the Context of His Constructive Philosophy", in Transforming Consciousness: Yogācāra Thought in Modern China, ed. John Makeham, New York: Oxford University Press, 2014, p. 242, note 2.

35 See Liang Shuming 梁漱溟, “Jiu yuan jue yi lun” 究元決疑論 (A study on exploring the origin and resolving doubts), Dongfang zazhi 東方雜誌 (Eastern miscellany), vol. 13, issue 7, 1916, p. 11.
} 
to Ouyang, and Xiong began his study of Buddhism in the Institute shortly afterwards. ${ }^{36}$

Between 1920 and 1922, Xiong studied Yogācāra Buddhism under Ouyang's supervision. ${ }^{37}$ This experience resulted in a significant change in Xiong's life, as what he had learnt during these two years provided not only the soil in which his philosophical system was rooted, but also the training for his later academic career. Soon after this experience, Xiong was offered a position as a lecturer in Yogācāra philosophy at Peking University. 38 From then on, until 1937, he received intermittent academic employment at several educational institutions.

This working environment provided Xiong with an atmosphere conducive to his intellectual development and in particular, to communicating with other scholars. When he was working at Peking University during the period between 1920 and 1937, for example, he had frequent discussions and exchanges with his colleague, Lin Zaiping 林宰平 (1878-1961). ${ }^{39}$ In his introduction to the 1932 Xin weishi lun 新唯識論 (New treatise on the uniqueness of consciousness), a work which can be said to represent the establishment of his mature metaphysics, Xiong stated that he had benefited greatly from Lin's frequent critiques of many important issues relating to Yogācāra learning. ${ }^{40}$ In addition to Lin Zaiping, Ma Yifu 馬一浮

36 Liang Shuming, Yi Xiong Shili xiansheng 憶熊十力先生 (Recollection of Mr. Xiong Shili), Taibei: Mingwen shuju, 1989, pp. 1-2.

37 Xiong's experiences at the China Institute of Inner Learning have been recorded in many accounts of his life and thought. See, for example: Cai, Xiong Shili xiansheng xuexing nianbiao, pp. 17-18; Ding, Xiong Shili xueshu sixiang pingzhuan, pp. 25, 340-341; Guo Qiyong, Tian di jian yige dushuren: Xiong Shilizhuan 天地間一個讀書人: 熊十力傳 (A scholar poised between heaven and earth: a biography of Xiong Shili), Shanghai: Shanghai wenyi chubanshe, 1994, pp. 35-37, 238-239; Song Zhiming, Xiong Shili pingzhuan, pp. 14-15, 205; Ye, Xiong Shili zhuan, pp. 86-92.

38 Liang, Yi Xiong Shili xiansheng, p. 2.

39 See Xiong, “Jinian Beijing daxue wushinian bing wei Lin Zaiping zhugu” 紀念北京大學五十年並 爲林宰平祝嘏 (In commemoration of the fifty years of Peking University and also in celebration of Lin Zaiping's birthday), Shili yuyao chuxu, p. 27.

40 Xiong, Xin weishi lun (wenyanwen ben, 1932) 新唯識論 (文言文本，一九三二年) (New treatise on the uniqueness of consciousness [literary version, published in 1932]), in Xiong Shili quanji, vol. 2, p. 9. 
(1883-1967), a famous twentieth-century Chinese scholar and one of the representative figures of New Confucianism, also played a significant role in the establishment of Xiong's philosophical system during this period. Xiong became acquainted with Ma in 1929.41 According to Xiong, in the process of composing his 1932 Xin weishi lun, he often discussed doubtful points with Ma, who helped him considerably as he developed the work. ${ }^{42}$ Moreover, between 1920 and 1937 Xiong also maintained regular communication with such contemporary scholars as Tang Yongtong 湯用彤 (1893-1964), Meng Wentong 蒙文通 (1894-1968), and Qian $\mathrm{Mu}$ 錢穆 (1895-1990). According to Qian Mu's recollection, these four scholars often met when they were working at Peking University. In their meetings, Meng and Xiong often argued about Xiong's views in the 1932 Xin weishi lun or about their different views on Neo-Confucianism, and Qian always reconciled the disputes. ${ }^{43}$ Presumably, those meetings must have been very helpful in Xiong's intellectual development.

Most of all, during the phase from 1920 to 1937, Xiong focused his attention primarily on the reconstruction of Yogācāra Buddhism, moving from a sympathetic interpretation of Yogācāra theories to a critical and creative reinterpretation of them. His 1923 Weishixue gailun 唯識學概論 (A general account of Yogācāra learning), which he composed on the basis of what he learnt in the China Institute of Inner Learning, is a generally faithful account of Yogācāra learning. However, he criticised and reconstructed Yogācāra theories in the 1926 Weishixue gailun 唯識 學概論 (A general account of Yogācāra learning) - a revised version of the 1923

\footnotetext{
41 See Makeham (trans. and annot.), New Treatise on the Uniqueness of Consciousness, p. 9, note 1; Wang Ruhua 王汝華, Xiandai rujia sansheng: Liang Shuming, Xiong Shili, Ma Yifu de jiaoyi jishi 現代 儒家三聖: 梁漱溟、熊十力、馬一浮的交誼紀實 (The three modern Confucian sages: a record of the associations between Liang Shuming, Xiong Shili, and Ma Yifu), Taibei: Xiuwei zixun keji gufen youxian gongsi, 2012, p. 26.

42 Xiong, Xin weishi lun (wenyanwen ben, 1932), p. 9.

43 Qian Mu 錢穆, “Yi Shili, Xiyu zhuyou” 憶十力、錫予諸友 (Recollection of various friends like Shili and Xiyu), in Xиanpu lunxue ji: Xiong Shili shengping yu xueshu 玄围論學集: 熊十力生平與學 術 (Collected works of academic discussions in the "treasured garden": Xiong Shili's life and learning), Beijing: Shenghuo, dushu, xinzhi sanlian shudian, 1990, p. 28.
} 
work - and Weishi lun 唯識論 (Treatise on Yogācāra), which was completed by early 1927.44 As Makeham points out, Xiong's 1932 Xin weishi lun represents his mature rejection of Yogācāra philosophy, although he still retained many elements of Yogācāra - deploying them for his own purposes - in this work. ${ }^{45}$

It was precisely in the midst of the transformation of his views on Yogācāra philosophy that Xiong progressively established his own philosophical system. Correspondingly, the basic theoretical framework of Xiong's philosophy was built to a large degree on a critical interpretation of Yogācāra theories. However, Xiong also absorbed many ideas from other philosophical traditions and his contemporaries between 1885 and 1937. As a result, in concert with the gradual development of his thought, Xiong increasingly integrated those ideas into his own system of thought. His ability to adopt and criticise various ideas freely in support of his own views can be considered a mark of the maturity of his thought by at least the 1932 Xin weishi lun. From 1932 to 1937, Xiong continued to strengthen and elucidate the ideas presented in his 1932 work.

After the outbreak of the Anti-Japanese War in 1937, Xiong's life and thought moved in a new direction: he ended the relatively stable academic life that he had led between 1920 and 1937 and began his escape from the chaos caused by the Second Sino-Japanese War. Because of the intense national crisis brought on by the war, rather than reconstructing Indian Yogācāra philosophy - an important goal for Xiong between 1920 and 1937 - he began to care more about the protection of traditional Chinese culture, and his writings from this time focused more intensely on identifying the value of traditional Chinese philosophy. I will not go into the details of this later period of Xiong's life and thought, however, because the scope

\footnotetext{
${ }^{44}$ I have found no direct evidence to confirm the publication date of this work, as will be discussed in the "Appendix" to Chapter Three.

45 Makeham, "Xiong Shili's Critique of Yogācāra Thought in the Context of His Constructive Philosophy", p. 243.
} 
of this study is limited to his thought between 1920 and 1937.

\section{An Overview of Xiong's Metaphysics}

Xiong's metaphysics, or onto-cosmology, which developed in crucial ways during this period of his life, focuses mainly on the concepts of Reality ( $t i$ 體) and Function (yong 用). ${ }^{46}$ This pair of concepts is one of the key conceptual polarities in traditional Chinese philosophy. Generally speaking, Reality refers to the ontological realm, the intrinsic reality of things; Function refers to the phenomenal world, the external manifestation of things. In the mature stage of his philosophy, Xiong frequently used the terms "Reality", or "Fundamental Reality" (benti 本體), ${ }^{47}$ and "Function" in his writings, and the ti-yong relationship was always the central component of his metaphysics: he developed his other primary philosophical theories around this core issue. Therefore, the appreciation of Xiong's understanding of Reality and Function is the key to comprehending his entire philosophical system.

According to Xiong, Reality and Function correspond to the concepts of "dharma-nature" (faxing 法性; dharmatā) and "dharma-characteristic" (faxiang 法相; dharma-lakșaṇa) in Indian Buddhism; 48 “noumenon” (shiti 實體) and "phenomenon" (xianxiang 現象) in Western philosophy; and "that which is above

\footnotetext{
46 In fact, scholars often translate $t i$ 體 into English as “substance”. However, as A. Charles Muller points out, the etymology of "substance" as "standing below" seems to denote more directly an ontological duality that is almost never implied by ti-yong. See A. Charles Muller, "The Emergence of Essence-Function (ti-yong) 體用 Hermeneutics in the Sinification of Indic Buddhism: An Overview”, Critical Review of Buddhist Studies, no. 19, June 2016, p. 125. Also, Xiong's ti-yong metaphysics developed from Buddhism, in which the ontological realm is considered to be the nature of things as they truly are, as contrasted to their illusory phenomenal appearances. Thus, I think that the word "reality" is more suitable to be used to translate $t i$ in this thesis. In addition, I capitalise the two words, "reality" and "function", when I use them to refer to ontological reality and its function.

47 In his writings, Xiong used "Fundamental Reality" as an alternative name for Reality. For clarity, I will simply refer to "Fundamental Reality" as "Reality" in what follows.

48 I have included what I believe to be the matching Sanskrit terms for some of the Buddhist terms in this thesis, which can highlight Xiong's usage of a long-established technical vocabulary.
} 
form is called the way" (xing'ershangzhe wei zhi dao 形而上者謂之道) and “that which is below form is called concrete thing" (xing'erxiazhe wei zhi qi 形而下者謂 之器) in studies on Zhouyi, or Yijing. ${ }^{49}$ As he noted, the former concept represents the ontological Reality of the universe and the latter the phenomenal world..$^{50}$ In his 1944 work, Xiong also explained why he chose to use the terms "Reality" and "Function", rather than the other terms mentioned above:

本論不盡沿用實體和現象，或法性和法相等詞，而特標體和用，這裡 卻有深意。我以爲, 實體和現象, 或形上和形下, 或法相和法性, 岰 不可截成二片的。因此, 我便不喜用現象、法相、形下等詞, 雖復時 沿用之, 要爲順俗故耳。因爲, 說個現象或法相與形下, 就是斥指已 成的物象而名之。已成的物象, 以下省云成象。我人於意想中, 計執有個成象 的宇宙, 即此便障礙了真理。真理, 謂本體。易言之, 乃不能於萬象而洞 徹其即是真理呈現。51

This treatise does not continue to use such terms as noumenon and phenomenon or dharma-nature and dharma-characteristic all the time, but instead specifically labels them as "Reality" and "Function". This indeed has profound significance. It is my opinion that noumenon and phenomenon, that which is above form and that which is below form, or dharma-characteristic and dharma-nature absolutely cannot be split into two [distinct] parts. Therefore, I do not like using terms such as

\footnotetext{
49 The terms "that which is above form is called the way" and "that which is below form is called concrete thing", which have been appropriated and interpreted by many Chinese philosophers, originate in "Xici" 繫辭 (Appended statements), a work attached to Zhouyi as a general commentary on its gist. See “Xici, shang" 繫辭上 (Appended statements, A), in Zhouyi zhengyi 周 易正義 (The correct meaning of the Book of Change), Shisan jing zhushu 十三經注疏 (The thirteen classics with annotations and sub-commentaries), compiled by Ruan Yuan 阮元, Taibei: Yiwen yinshuguan, 1981, vol. 1, p. 158.

50 Xiong, Xin weishi lun (yutiwen ben, 1944) 新唯識論 (語體文本, 一九四四年) (New treatise on the uniqueness of consciousness [vernacular version, published in 1944]), in Xiong Shili quanji, vol. 3, pp. 151-152, 235-236.

51 Ibid., pp. 236-237. The text in a smaller font size is Xiong's interlinear auto-commentary, which runs throughout Xiong's writings and which plays an important role in demonstrating his views.
} 
"phenomenon", "dharma-characteristic" and "that which is below form" - although sometimes I do still continue to use them, mainly for the sake of following convention, and no more. That is because to say "phenomenon", "dharma-characteristic" or "that which is below form" is precisely to point out phenomena that have already been formed and to name them. "Phenomena that have already been formed" will be abbreviated as "formed phenomena" hereafter. In our conceptual perceptions we become attached to the imaginative discrimination that there exists a formed phenomenal universe, and it is precisely this that obstructs truth. ${ }^{52}$ "Truth" refers to Reality. To put it another way, we fail to realise through penetrative understanding of the myriad phenomena that they are precisely the direct presentation of truth.

By appropriating the terms "Reality" and "Function", Xiong intended to express his view that the ontological and the phenomenal are not distinct. In his opinion, such expressions as "phenomenon", "dharma-characteristic", and "that which is below form is called concrete thing" are used to point out and name phenomena, which are formed due to our mistaken attachment to them as real things, things with selfnature. For him, it is precisely because of this mistaken attachment that we are unable to realise the ontological Reality of the universe. In contrast, Reality and Function as a conceptual polarity stand in relation to each other: Reality is the Reality of Function, and Function is the Function of Reality. Therefore, he employed the ti-yong polarity to emphasise that the phenomenal universe actually is the manifestation of ontological Reality, and so the two are non-dual.

Indeed, scholars usually have considered the "non-duality of Reality and Function” (ti yong bu'er 體用不二) to be the most representative idea in Xiong's philosophy. For example, Ng Yu-kwan believes that the core of Xiong's thought is

\footnotetext{
52 In his writings, Xiong sometimes used such terms as zhenli 真理 and zhenshi 真實 to refer to ontological Reality. For clarity, I will translate these terms uniformly as "truth" in this thesis.
} 
the idea of the non-duality of Reality and Function. ${ }^{53}$ Nonetheless, it still should be noted that this idea underwent a long process of formation and development. This process is reflected primarily in a series of works Xiong composed between the early 1920s and the late 1950s. In 1923, he published the Weishixue gailun, in which he expressed his preliminary views of Reality and Function. Thereafter, he modified, developed and refined those views repeatedly over the next four decades, largely in the following different versions of his 1923 work: the Weishixue gailun, which he published in 1926 with the same title as the earlier work; Weishi lun, completed by early 1927; the Xin weishi lun, published in 1932; Xin weishi lun 新唯識論 (New treatise on the uniqueness of consciousness), the vernacular version of his 1932 Xin weishi lun, which was published in 1944; Xin weishi lun 新唯識論 (New treatise on the uniqueness of consciousness), a expurgated and finalised version of his Xin weishi lun, published in 1953; and Ti yong lun 體用論 (Treatise on Reality and Function), published in 1958. Among these works, the 1932 Xin weishi lun can be said to mark the first mature expression of Xiong's idea of the non-duality of Reality and Function.

\section{Objectives and Methods of the Study}

This thesis is a study in the intellectual history of modern Chinese philosophy. Its purpose is to examine Xiong's understanding of Reality and Function between 1920 and 1937. From Xiong's life and thought introduced above, we can see that before 1920, Xiong's philosophical ideas remained inchoate. In 1920, however, he began to study Buddhism systematically in Nanjing at the China Institute of Inner Leaning, and from this point began to develop his ti-yong philosophical system. His $1932 \mathrm{Xin}$

\footnotetext{
53 Ng Yu-kwan, "Xiong Shili's Metaphysical Theory about the Non-separability of Substance and Function", in New Confucianism: A Critical Examination, ed. John Makeham, New York: Palgrave Macmillan, 2003, p. 224. Sor-hoon Tan also states: "The keystone of Xiong's metaphysical monism is the non-duality of substance and functions (ti yong bu'er 體用不二).” Sor-hoon Tan, “Contemporary Neo-Confucian Philosophy", in History of Chinese Philosophy, ed. Bo Mou, London: Routledge, 2009, p. 541.
} 
weishi lun represents the first expression of his mature ti-yong philosophical system. From then until 1937, he strengthened and elucidated the ideas presented in this work. After 1937, because of the intense national crisis, his philosophy moved in a new direction by focusing more on identifying the value of traditional Chinese culture. Accordingly, the years from 1920 to 1937 mark the gradual establishment of Xiong's ti-yong philosophical system and represent a crucial phase in his philosophical development.

The purpose of this study - to examine Xiong's understanding of Reality and Function between 1920 and 1937 - can be further divided into two specific objectives. The first is to reveal the evolution of Xiong's understanding of Reality and Function during this period. By tracing the changes in, and development of, his conception of these two concepts, this thesis aims to demonstrate how his idea of the non-duality of Reality and Function formed and matured gradually. Since this idea is the "core" of Xiong's thought, this will not only help us gain a more accurate understanding of this idea itself, but also make his whole philosophical system more intelligible.

In order to accomplish the first objective, after examining all of his writings during this period, I divide Xiong's understanding of Reality and Function in the period from 1920 to 1937 into three chronological stages, and provide a detailed explanation of his account of Reality and Function in each stage. Further, by comparing his views in later stages with those in preceding stages, I point up the changes in, and the development of, his thought.

The second objective is to clarify the sources on which Xiong drew between 1920 and 1937 to elucidate his ideas of Reality and Function. Xiong was a syncretist, ${ }^{54}$ and so his philosophy cannot be explored independently of the sources he absorbed. As we have seen, before 1920 Xiong drew widely on

\footnotetext{
${ }^{54}$ In regard to this point, See Makeham, "Xiong Shili's Critique of Yogācāra Thought in the Context of His Constructive Philosophy", pp. 280-282; New Treatise on the Uniqueness of Consciousness, pp. xxii-xxiii.
} 
traditional Chinese philosophy, in particular on Neo-Confucianism and Zhouyi. In the early 1920s, he was trained systematically in Yogācāra Buddhism. Moreover, his thought was inspired by his contemporaries and reflects his position on certain philosophical issues. All of these factors contributed to his views of Reality and Function in the period between 1920 and 1937. By identifying the sources that shaped Xiong's thinking, this study further sheds light on the formation of his tiyong philosophical system and, as a corollary, contributes to a more accurate understanding of the later, mature stage of his thought.

I address this second objective by examining the formation and development of the ti-yong polarity in Chinese philosophy before Xiong. I also analyse Xiong's biographical information to determine whose ideas he encountered before 1937. This study identifies those sources that seem to be associated clearly with Xiong's views of Reality and Function in the period between 1920 and 1937. To confirm those connections, I offer three forms of evidence: (1) Xiong's own discussions (both endorsements and critiques) of certain philosophical ideas, which reflect his perspectives on Reality and Function; (2) the appearance of terms or modes of expression in Xiong's writings that echo those in earlier philosophical texts; and (3) the obvious similarities (and even differences) identified by myself between Xiong's views and others' philosophical ideas.

\section{Significance of the Study}

New Confucianism has become a very important topic of academic research over the past several decades, and many of its main representatives, such as Liang Shuming and Mou Zongsan, have already been widely studied by scholars in East Asia and in the West. By contrast, Xiong Shili has still not received sufficient attention in the West, despite his major contributions to the development of Confucian and Buddhist philosophy; the active state of studies on Xiong is restricted to the Chinese-language circle. Yet, even Chinese-language studies fail to pay attention to the early development of Xiong's ti-yong philosophy. Indeed, there has 
been almost no research in any language on the early development of Xiong's $t i$ yong metaphysics. Instead, scholars have tended to focus only on the mature stage of his philosophy. Many have drawn conclusions on the basis of a limited and selective analysis of Xiong's representative works, 55 overlooking how his ideas were developed over an extended period. As a result, there is a need for a systematic study that closely examines the different developmental stages of Xiong's ti-yong metaphysics during its formative period.

As already noted, Xiong's mature ti-yong philosophical system began to be established and consolidated in the 1930s, with the formative process beginning in 1920. Investigating this process of development will not only help us to make better sense of the later, mature stage of Xiong's thought, but also contribute to our understanding of his overall philosophical development more accurately. Also, investigating and clarifying this early development of Xiong's ti-yong metaphysics not only better enables us to identify the changes he made in his later thought, but also to determine what were the central and sustained philosophical problems he was grappling with over this period of change and development.

By examining the long-term development of Xiong's ti-yong philosophy between 1920 and 1937, and by identifying the sources on which he drew at each of the formative stages in this development, we can bring greater precision to a

\footnotetext{
55 See, for example: Li Zehou 李澤厚, “Lüe lun Xiong Shili: lüe lun xiandai xinrujia zhiyi” 略論熊十 力一一略論現代新儒家之一 (A brief discussion of Xiong Shili: a brief discussion of the one of modern New Confucians), in Xiong Shili quanji, supplementary volume B, pp. 929-947; Ma Tianxiang 麻天祥, “Zhezhong kong you yu Yi de benxin bentilun” 折衷空、有於《易》的本心本體論 (An ontology of the inherent mind that integrates the Emptiness and the Existence schools into the Book of Change), in Xuanpu lunxue xuji: Xiong Shili yu Zhongguo chuantong wenhua guoji xueshu yantaohui lunwenji 玄戋論學續集: 熊十力與中國傳統文化國際學術研討會論文集 (A sequel to Collected Works of Academic Discussions in the "Treasured Garden": the proceedings of the International Symposium on Xiong Shili and Traditional Chinese Culture), ed. Wuhan daxue Zhongguo chuantong wenhua yanjiu zhongxin 武漢大學中國傳統文化研究中心, Wuhan: Hubei jiaoyu chubanshe, 2003, pp. 130-137; Shi Zhonglian 施忠連, “Chuantong de zhexue huayu; zui xin de zhexue guannian: lun Xiong Shili de chuangzao zhexue” 傳統的哲學話語 最新的哲學觀念一一論熊十力的創造哲學 (Traditional philosophical utterance; the newest philosophical ideas: a discussion of Xiong Shili's creative philosophy), ibid., pp. 159-164.
} 
number of aspects of Xiong's thought, such as: the extent to which he developed ideas that were already well formed; the extent to which he departed from earlier thinkers; how and why he increasingly adopted a critical attitude towards Yogācāra philosophy; how and why he gradually drew closer to such Sinitic Buddhist traditions as Huayan 華嚴; and the extent to which he consciously and deliberately tried to be syncretic in developing his metaphysics. I hope that this study of Xiong's metaphysics between 1920 and 1937 will provide a more comprehensive basis for studies on the later periods of Xiong's philosophical thought. I also hope that a systematic division of Xiong's thought into chronological stages, as well as the attention paid to the sources of his ideas, will inspire future studies of Xiong's philosophy.

Because Xiong developed his ti-yong philosophy drawing on traditional accounts of the concepts of Reality and Function, by clarifying the sources of Xiong's thought, this study also offers a suggestive case study of how traditional Chinese philosophy, with particular respect to the ti-yong conceptual polarity, was inherited and developed in the early twentieth century. In particular, this study demonstrates the originality of Xiong's understanding of Reality and Function and highlights the areas in which his ti-yong philosophy made a unique contribution to the development of this long-standing conceptual polarity.

\section{Chapter Outlines}

This thesis consists of an introduction, four chapters, and a conclusion. To facilitate a better understanding of Xiong's thought in the later chapters, Chapter One provides an account of the philosophical background against which Xiong developed his ti-yong philosophy between 1920 and 1937. It first introduces the $t i$ yong conceptual polarity in traditional Chinese philosophy, since, as a scholar who drew largely from traditional Chinese philosophy, Xiong's understanding of Reality and Function must be understood in this broader context. It then discusses Xiong's thinking on the phenomenal world and its Reality before 1920. This thinking 
supplied a basis for Xiong's later exploration of Reality and Function and became a nodal point for his ti-yong philosophy. Finally, it surveys the "genuine Buddhism" (zhenshi foxue 真實佛學) movement and its related debates, which occurred between Xiong's colleagues at the China Institute of Inner Learning and other contemporaries. The movement and debates reflect two different opinions about Reality and Function and must have informed Xiong's own ideas about these concepts.

The remaining chapters are structured based on my division into the chronological stages of the development of Xiong's understanding of Reality and Function from 1920 to 1937. Chapter Two examines Xiong's conception of Reality and Function between 1920 and 1923. Xiong did not elaborate his views of Reality and Function systematically in this stage, but he did express some ideas about these concepts in his 1923 Weishixue gailun. Although those ideas are quite scattered in this work, they laid important foundations for Xiong's later systematic ti-yong philosophy. Thus, this chapter focuses on Xiong's ideas of Reality and Function in his 1923 work. This work concentrates on explicating Yogācāra philosophy, and Xiong's explanations of certain Yogācāra theories reflect his understanding of Reality and Function at that time. The chapter therefore pays considerable attention to how Xiong interpreted relevant Yogācāra theories. It also indicates those places where Xiong deviated from Yogācāra Buddhism or integrated ideas from other philosophical schools, as those played an important role in Xiong's expression of his views on Reality and Function.

Chapter Three shows how, between 1923 and 1927, Xiong revised his views of Reality and Function presented in his 1923 work. The process of this revision can be divided into two steps, reflected in his 1926 Weishixue gailun and his Weishi lun, respectively. Through these two steps, Xiong finally realised the oneness of the ontological and the phenomenal. This chapter deals principally with Xiong's 1926 work and Weishi lun to reveal how this was achieved. Moreover, during this stage, Xiong's revision of his previous views of Reality and Function was achieved largely 
through his critique and reconstruction of certain Yogācāra theories, as well as his adoption of some ideas from other philosophical schools. Correspondingly, this chapter also clarifies these approaches.

Chapter Four discusses the further development of Xiong's conception of Reality and Function between 1927 and 1937 by examining his thought in the 1932 Xin weishi lun and a selection of other writings from this period. At this stage, Xiong incorporated more ideas from traditional Chinese philosophy, as well as from his contemporaries, so as to form a more complete metaphysical system. This chapter identifies the principal sources that contributed to the generation of his new ideas of Reality and Function. In doing so, it illustrates how Xiong interpreted the nonduality of Reality and Function in a new way compared to his previous elucidation of this theory.

In the Conclusion, this thesis reviews Xiong's changing understanding of Reality and Function from 1920 to 1937 and attempts to address two main questions: Why is Xiong's philosophy of Reality and Function unique? Why did he continue to modify and develop his understanding of Reality and Function between 1920 and 1937? The answer to each of these questions in turn touches on several corollary, but important, issues of Xiong's thought during this period. 


\section{Chapter One}

\section{The Philosophical Background to the Development of Xiong's Ti-yong Metaphysics}

In order to better comprehend Xiong's understanding of Reality and Function later in this thesis, this chapter aims to provide the philosophical background against which Xiong developed his ti-yong metaphysics between 1920 and 1937. It is divided into three sections, which, in turn, are outlined in what follows.

The first section introduces the formation and development of the ti-yong conceptual polarity in Chinese philosophical history. As mentioned in the Introduction, the most representative idea in Xiong's thought is "the non-duality of Reality and Function", and the development of his ti-yong philosophy between 1920 and 1937 was also a process in which that idea formed and matured gradually. In fact, the idea that Reality and Function are non-dual was not initiated by Xiong but is rooted in traditional Chinese philosophy. This section pays particular attention to how this idea had been interpreted in Chinese philosophical history before Xiong, which can help us understand why Xiong's interpretation of, and approach to, this idea are unique and creative when his thought is elaborated in the following chapters of this thesis.

The second section discusses Xiong's early thinking on the phenomenal world and its Reality before 1920. Although Xiong only began to establish his tiyong philosophy in the early 1920s, his ruminations on the ontological and the phenomenal can be traced back to an earlier period. Through examining his early thinking on this issue, this section provides a basis on which we will be able to see later that Xiong's mature understanding of Reality and Function, as presented in the 1930s, is to some extent both a return to and the development of his early thought. 
The third section introduces the "genuine Buddhism" movement and its related debates that occurred in the early decades of the twentieth century. The movement and debates reflect two different opinions about Reality and Function. The examination of these opinions in this section will enable us to see how Xiong's understanding of Reality and Function between 1920 and 1937 fits into this broader context.

\subsection{The Formation and Development of the Ti-yong Conceptual Polarity in Chinese Philosophical History}

Ti and yong constitute a very important conceptual polarity that has been used widely by Chinese philosophers in different historical periods. 56 Yet the transformation of $t i$ and yong from being two individual concepts to forming a philosophical polarity took place over a long time. Also, both the denotations and connotations of ti and yong are not absolute but have changed and developed continually over the past two thousand years.

The basic and original meanings of $t i$ and yong are the body (of both a human being and an object) and the function or use of a thing, respectively. For example, in the pre-Qin period (pre-221 BC), Xunzi 荀子 (third century BC), a philosopher who has been noted by many scholars as an important contributor to using these two concepts together, ${ }^{57}$ stated:

萬物同宇而異體，無宜而有用爲人，數也。58

\footnotetext{
56 For the concept of polarity, see Roger T. Ames, "Putting the Te back into Taoism", in Nature in Asian Traditions of Thought: Essays in Environmental Philosophy, eds. J. Baird Callicott and Roger T. Ames, Albany: State University of New York Press, 1989, pp. 119-121.

57 See, for example, Zhang Dainian 張岱年, Zhongguo gudian zhexue gainian fanchou yaolun 中國 古典哲學概念範疇要論 (On the key concepts and categories in classical Chinese philosophy), Beijing: Zhongguo shehui kexue chubanshe, 1989, p. 62; Zhang Liwen 張立文, Zhongguo zhexue fanchou fazhanshi (tiandao pian) 中國哲學範疇發展史（天道篇） (The developmental history of Chinese philosophical categories [on the way of heaven]), Beijing: Zhongguo renmin daxue chubanshe, 1988, p. 626.

58 Xunzi 荀子, “Fu guo pian” 富國篇 (On enriching the country), in Wang Xianqian 王先謙, Xunzi
} 
The myriad things share the same universe, but their bodies are different. They have no intrinsic appropriateness yet are of use to humans. This is the natural order [of things]. ${ }^{59}$

It can be seen that here $t i$ and yong only mean the physical body and the imbued use of things, but they appear not to carry any philosophical meaning. Further, although these two characters are used together in Xunzi's statement, they are presented as two individual concepts rather than a conceptual polarity. As Zhang Dainian 張岱年 (1909-2004) and Shimada Kenji 島田虔次 (1917-2000) have both noted, Xunzi presented ti and yong together here merely "by chance". 60 Actually, there has so far been no evidence found to suggest that these two characters were used as a distinct philosophical polarity in the pre-Qin period. The examples of $t i$ and yong used in this period provided by scholars have only proven that on the whole the writings of this period talk about these two characters separately rather than as a pair of connected concepts. ${ }^{61}$ As a result, the meanings of $t i$ and yong as a philosophical polarity were not open to exploration at the time. That philosophical meaning of the ti-yong conceptual polarity concerns how identity and difference are to be understood.

There has been a dispute since the Song dynasty (960-1279) over when and where the two concepts of $t i$ and yong first appeared as a philosophical polarity.

jijie 荀子集解 (The variorum commentary on Xunzi), Beijing: Zhonghua shuju, 1988, p. 175. I follow Wang Xianqian's 王先謙 (1842-1917) punctuation for this sentence.

${ }^{59}$ I consulted John Knoblock's translation of this sentence. See John Knoblock, Xunzi: A Translation and Study of the Complete Works, Stanford, Calif.: Stanford University Press, 1988-1994, vol.2, p. 120. 60 Zhang Dainian, Zhongguo zhexue dagang 中國哲學大綱 (An outline of Chinese philosophy), Nanjing: Jiangsu jiaoyu chubanshe, 2005, p. 38; Shimada Kenji 島田虔次, Zhongguo sixiangshiyanjiu 中國思想史研究 (A study on Chinese intellectual history), trans. Deng Hong 鄧紅, Shanghai: Shanghai guji chubanshe, 2009, p. 225.

${ }^{61}$ For instance, the contemporary scholar Zhang Liwen 張立文 outlines the situation of the usage of $t i$ and yong in the pre-Qin period in his Zhongguo zhexue fanchou fazhanshi (tiandao pian), pp. 625-626. From his depiction, it can be seen that Xunzi's statement seems to be the only example where these two characters are used together in one sentence. In fact, this case also exists in other contemporary scholars' discussions on the usage of $t i$ and yong in the pre-Qin period. 
One line of thought links it to some writings in such indigenous Chinese philosophical schools as Confucianism and Daoism, while another suggests that the philosophical meaning of the ti-yong conceptual polarity has its roots in certain Buddhist texts. ${ }^{62}$ As A. Charles Muller states, traditionally, the first philosophical exegetic application of ti-yong is attributed to the metaphysician Wang Bi 王貆弓 (226-249) in his commentary to the Daode jing 道德經 (The book of the way and virtue) of Laozi 老子 (trad. sixth-fifth centuries BC).63 Indeed, by examining that dispute on the source of ti-yong mentioned above, it seems that $t i$ and yong as a philosophical polarity can be traced back to the Wei dynasty (220-266), in which Wang Bi stated:

[萬物]雖貴, 以無爲用, 不能捨無以爲體也。(不能) 捨無以爲體, 則 失其爲大矣。 64

Although [the myriad things] are noble, their functioning is based on "not-having", and they cannot reject taking not-having as their Reality. If they were to reject taking not-having as their Reality, then they would lose their power to be great. 65

62 See Yuan Weijie 袁偉傑, “Ti yong guannian laiyuan zhi zhengyi kao” 體用觀念來源之爭議考 (An inquiry into the dispute on the source of the ti-yong idea), Shiyi 史繹, issue 36, 2011, pp. 1-29. ${ }^{63}$ Muller, "The Emergence of Essence-Function (ti-yong) 體用 Hermeneutics in the Sinification of Indic Buddhism", p. 120. Yet, as Muller further notes, the evidence that Wang Bi was the first to actually use the ti-yong philosophical polarity is not fully conclusive. Ibid., note 10.

64 See Lou Yulie 樓宇烈, Wang Bi ji jiaoshi 王弶集校釋 (Collation and annotation of the collected writings of Wang Bi), Beijing: Zhonghua shuju, 1980, p. 94. As Lou Yulie 樓宇烈 notes, the word in the brackets, “不能”, is a redundancy due to miscopying, and so this word should be deleted in order to make Wang Bi's statement logical and comprehensible. Ibid., p. 102.

${ }^{65}$ For this translation, I have consulted both Lou Yulie's annotations of Wang Bi's words and also Richard John Lynn's English translation of Wang's sentence. See Lou's annotations in ibid., pp. 101102; Richard John Lynn, The Classic of the Way and Virtue: A New Translation of the Tao-te ching of Laozi as Interpreted by Wang Bi, New York: Columbia University Press, 1999, pp. 121-122. Yet there have been various translations of this statement. For those that differ from mine, see, for example, Wagner G. Rudolf, A Chinese Reading of the Daodejing: Wang Bi's Commentary on the Laozi with Critical Text and Translation, Albany: State University of New York Press, 2003, p. 245; Ariane Rump (in collaboration with Wing-tsit Chan), Commentary on the Lao Tzu by Wang Pi, Honolulu: The University Press of Hawaii, 1979, p. 112; Paul J. Lin, A Translation of Lao Tzu's Tao Te Ching and Wang 
In this statement, the concepts of $t i$ and yong are used to denote the ontological Reality and the functions of the myriad things in the universe. "Not-having" ( $w u$ 無), an abstract concept that originates in the philosophy of Laozi, is conceived as the ontological Reality of the universe, based on which the functions of the myriad things are able to be exerted. Although yong in this case refers only to specific functions of things in the phenomenal universe, the concepts of $t i$ and yong are used indeed as a polarity that is endowed with a philosophical sense in this statement. ${ }^{66}$

Although Wang Bi presented ti and yong as a philosophical polarity in his statement, this kind of usage of the two concepts had yet to become common in Wang's era. Although Tang Yongtong once stated that the various debates during the period of Wei, Jin (266-420), and the Southern and Northern dynasties (420589) all centred on ti-yong, ${ }^{67}$ in my opinion, the application of $t i$ and $y o n g$ in Tang's statement is probably an acknowledgement of the use of these two terms in the Buddhist philosophy of the day. That is, ti refers to ontological Reality and yong refers to the myriad phenomena. Thus, it does not mean that the two characters of ti and yong were already being commonly used as a philosophical polarity in Wang Bi's era. After all, as many scholars have noted, there were few discussions in which ti and yong are employed together at that time. ${ }^{68}$

Pi's Commentary, Ann Arbor: Center for Chinese Studies, The University of Michigan, 1977, p. 71.

66 The proper way to understand Wang Bi's statement has also been disputed, and there are various interpretations of it. For these different interpretations, see, for example, Li Xiaochun 李曉春, “Wang Bi 'ti yong lun' shuzhen” 王弶 “體用論” 述真 (A discussion on Wang Bi's theory of ti-yong), Lanzhou daxue xuebao (shehui kexue ban) 蘭州大學學報 (社會科學版), vol. 38, issue 4, July 2010, pp. 12-17; Liu Liangjian 劉梁劍, “Wang Bi lun ti yong guanxi” 王㢶論體用關係 (Wang Bi's discussions on the relationship between ti and yong), Bohai daxue xиebao (zhexue shehui kexue ban) 渤海大學學報 (哲學社會科學版), issue 2, 2004, p. 24.

67 Tang Yongtong 湯用殁, Han Wei LiangJin NanBeichao fojiao shi 漢魏兩晉南北朝佛教史 (Buddhist history during the Han, Wei, the two Jins, and the Southern and Northern dynasties), Banqiao shi: Luotuo chubanshe, 1987, p. 333.

68 See, for example, Shimada, Zhongguo sixiangshi yanjiu, trans. Deng Hong, p. 227. In the following page of this book, Shimada provided two possible answers as to why Tang Yongtong made that comment: first, although the two characters, ti and yong, had yet to form a commonly used philosophical polarity prior to the early or middle period of the Southern and Northern dynasties, 
In spite of this, the usage of $t i$ and yong as a philosophical polarity grew significantly in Chinese philosophical history subsequently. These two concepts gradually formed a paradigm that reflects certain types of relatedness. As Zhang Dainian pointed out, the relations between an object and its inherent movement or activity, between the fundamental metaphysical nature of a thing and its expression, between moral principles and their implementation by individuals, are all encompassed in the ti-yong paradigm. ${ }^{69}$ Since $t i$ and yong are conceived as bearing a relation to each other, that is, $t i$ is the ti of yong, and yong is the yong of $t i$, the two are usually considered to be a polar whole, inseparable and, thus, non-dualistic. For instance, in the Liang dynasty (502-557), Shen Ji 沈績 (fl. 502-508), an official of Emperor Wu of Liang (464-549), presented his view on the relationship between $t i$ and yong as:

\section{既有其體, 便有其用。語用非體, 論體非用。……體之與用, 不離不即。 離體無用，故云不離; 用義非體，故云不即。70}

conceptual polarities that approximate ti-yong, such as ben-mo 本末 (root and branches) and zhiyong 質用 (substance and function), had already been frequently used in philosophical discussions at the time; second, during the period of Wei, Jin, and the Southern and Northern dynasties, ti-yong thought had not reached the level suggested in Tang's comment. The first of these two possibilities is similar to my opinion. In fact, as A. Charles Muller has demonstrated, philosophical paradigms analogous to ti-yong can be discerned in texts going back as far as the fifth century BC, being expressed in such forms as dong-jing 動靜 (movement and stillness). See Muller, "The Emergence of Essence-Function (ti-yong) 體用 Hermeneutics in the Sinification of Indic Buddhism", pp. 115116.

${ }^{69}$ Zhang Dainian, Key Concepts in Chinese Philosophy, trans. and ed. Edmund Ryden, Beijing: Foreign Languages Press, 2002, p. 240. On this point, see also Zhang Liwen, Zhongguo zhexue fanchou fazhanshi (tiandao pian), pp. 622-624.

70 See Shen Ji's annotations to the sentences in Emperor Wu of Liang, "Li shenming cheng fo yi ji" 立神明成佛義記 (Record of the meaning of concsiousness' attaining Buddhahood), in Hongming ji 弘明集 (Collection on the propagation and elucidation [of Buddhism]), compiled by Sengyou 僧祐, vol. 9, in the CBETA (Chinese Buddhist Electronic Text Association) edition of the Taishō Tripitaka (Taishō revised Tripițaka), available at: http://www.cbeta.org/, T52n2102_009, 0054a18. For the context and an explanation of this passage, see John Makeham, "Chinese Philosophy's Hybrid Identity", in Why Traditional Chinese Philosophy Still Matters: The Relevance of Ancient Wisdom for the Global Age, ed. Ming Dong Gu, London: Routledge, 2018, pp. 159-160. For a detailed discussion of Emperor Wu's "Li shenming cheng fo yi ji”, see Whalen Lai, "Emperor Wu of Liang on the Immortal 
Since there is the $t i$, then there is its yong. If we talk about yong, [however,] it is not $t i$; and if we discuss $t i$, it is not yong. ... Ti and yong are neither separate nor identical. There is no yong without $t i$, so it is said that they are not separate; the referent of yong is not [that of] $t i$, so it is said that they are not identical.

This is a typical example in which the non-duality of $t i$ and yong is presented and explained explicitly.

The idea that $t i$ and yong are non-dual has been widely used in Chinese ontological philosophy, in which ti refers to ontological Reality, while yong refers to the phenomenal world, the Function or manifestation of ontological Reality. There have been many Chinese thinkers, in particular those of Buddhism and NeoConfucianism, who contributed to the understanding of Reality and Function and who interpreted the non-duality of the pair in their own ways. As we shall see in this thesis, Xiong developed his own understanding of Reality and Function drawing especially on the Buddhist and the Neo-Confucian discussions of this conceptual polarity. Thus, what follows will introduce some prominent and influential perspectives concerning Reality and Function that are drawn from these two schools, with a focus on those that seem to be related to Xiong's thought between 1920 and 1937. Particular attention will be paid to how the thinkers who presented those perspectives interpreted the non-duality of Reality and Function respectively, which will in turn provide an understanding of the philosophical context in which Xiong developed his unique and creative interpretation of this idea.

\subsubsection{Buddhist Discussions on Reality and Function}

The question of when Buddhism was first introduced into China has been controversial. Yet there is no doubt that it was in the Wei-Jin period that Buddhism first gained its prominent place in Chinese philosophy. As Wing-tsit Chan indicated, 
in the Eastern Jin dynasty (317-420), the arena of Chinese philosophy was dominated by Buddhists rather than by Confucian or Daoist thinkers. From then on for several hundred years, the story of Chinese philosophy was that of Buddhism. ${ }^{71}$

It was precisely in the boom period of Buddhism during the Wei, Jin, and the Southern and Northern dynasties that many Buddhist scholars grappled with the issue of the ontological and the phenomenal. As Tang Yongtong pointed out, during this period, Buddhism, along with xuanxue 玄學 (mysterious learning), ${ }^{72}$ valued "the absence of characteristics" ( $w u$ 無) whilst making light of "that which has characteristics" (you 有). It considered the former to be the "root" (ben 本), which refers to the ontological realm, and the latter to be the "branches" (mo 末), which refers to the myriad things in the phenomenal world. Although there were various debates and views among scholars at the time, the question of the relationship between the ontological and the phenomenal was dominant. ${ }^{73}$

Among those Buddhist scholars who talked about the ontological and the phenomenal during this period, Sengzhao 僧肇 (384-414), a famous monk in the

\footnotetext{
71 Chan, A Source Book in Chinese Philosophy, p. 337.

72 Хиапхие refers to an ideological trend mainly associated with the Wei-Jin period, during the second and third centuries. In a narrow sense, it is represented by He Yan 何晏 (?-249), Wang Bi 王㢶 (226-249), Xiang Xiu 向秀 (trad.227-272), and Guo Xiang 郭象 (?-312). In a broader sense, it includes the Buddhist metaphysics, represented by Sengzhao 僧肇 (484-414). These thinkers developed the ideas in Laozi 老子, Zhuangzi 莊子 and Zhouyi, and discussed such philosophical issues as "root (ben 本) and branches (mo 末)”, “the absence of characteristics (wu 無) and that which has characteristics (you 有)", and so on. See Wei Zhengtong 韋政通, Zhongguo zhexue cidian daquan 中國哲學辭典大全 (A complete dictionary of Chinese philosophy), Beijing: Shijie tushu chuban gongsi, 1989, pp. 231-232. For other explanations of xuanxue, see, for example, John Makeham, Transmitters and Creators: Chinese Commentators and Commentaries on the Analects, Cambridge, Mass.: Harvard University Asia Centre, 2003, p. 25, note 6.

73 Tang, Han Wei LiangJin NanBeichao fojiao shi, p. 333. According to Tang, the use of the two pairs of concepts, "the absence of characteristics and that which has characteristics" and "root and branches", to describe the ontological realm and the myriad things in the universe can be traced back to the pre-Qin period. At that time, Laozi presented the "way" (dao 道) as the ontological realm, and he explained the relationship between the way and the myriad things by using the two pairs of concepts mentioned above. For Laozi, the way is "the absence of characteristics" and the "root", which generates the myriad things, that is, "that which has characteristics" and the "branches". Ibid., p. 273.
} 
Eastern Jin dynasty, was one of the earliest to appropriate the terms ti and yong for this issue. In his essay “Wu bu qian lun” 物不遷論 (Things do not shift), Sengzhao explored the real nature of "flowing and moving" (liudong 流動) phenomena. ${ }^{74}$ According to him, although things seem to move, they are actually stationary, as they can only remain at their moments of occurrence and cannot move to another moment of occurrence. The previous things do not move from the past to the present, and the present things do not move from the present to the past. ${ }^{75}$ In this sense, the “not moving” (bu dong 不動), “not shifting” (bu qian 不遷), or “stillness” (jing 靜) in Sengzhao's formulations is the real nature of things. For Sengzhao, this real nature of things is not different from their seeming movement:

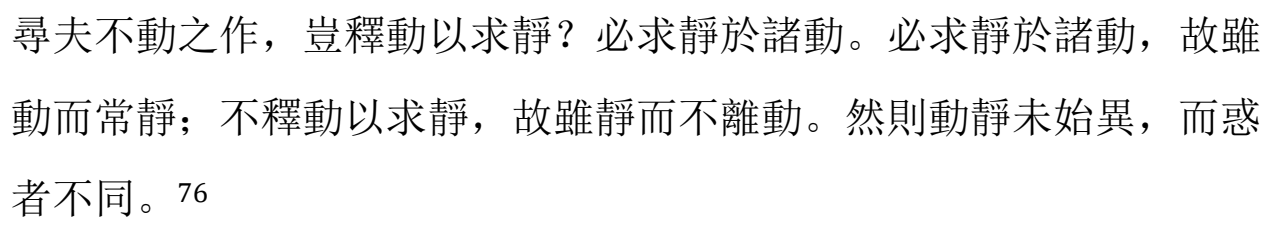

To inquire into the case of not moving, how can we seek stillness by abandoning movement? Stillness must be sought in movement. Since stillness must be sought in movement, then although there is movement, it is constantly still. Since movement is not adandoned to seek stillness, then although there is stillness, it is not separate from movement. Accordingly, movement and stillness have never been different - only deluded people differentiate [them].

Stillness must be sought within movement because just as things from the present do not move to the past, things from the past do not move to the present. Nothing

\footnotetext{
74 The "flow and movement" of phenomena in the "Wu bu qian lun" indicate the changes in things, such as the transformation between birth and death and the alternation of seasons, which, according to Sengzhao, are "natural and normal to worldly people". See Sengzhao 僧肇, “Wu bu qian lun” 物 不遷論 (Things do not shift), Zhao lun 肇論 (Essays by Sengzhao), in the CBETA edition of the Taishō Tripițaka, T45n1858_001,0151a09.

75 Ibid., 0151a20. On Sengzhao's point, see also Makeham (trans. and annot.), New Treatise on the Uniqueness of Consciousness, pp. 157-158, note 55.

76 Sengzhao, "Wu bu qian lun", 0151a09.
} 
can depart from its immediate moment of occurrence and move to another moment of occurrence. Past things do not reach the present because they do not move from the past to the present. If they moved, they would not be past things. Present things do not reach the past because they do not move from the present to the past. If they moved, they would not be present things. Therefore, there is no movement.

Sengzhao's presentation of his view that stillness and movement are not different was based on his belief that the two have the same Reality. This can be seen from his statement in another work, Bore wuzhi lun 般若無知論 (Wisdom knows nothing):

用即寂，寂即用。用寂體一，同出而異名。更無無用之寂，而主於用 也。 77

Function is not different from quiescence; quiescence is not different from Function. Function and quiescence share the same Reality. They emanate from the same [source] but have different names. There is no additional quiescence [that exists] in the absence of Function and then controls Function.

Here "Function" and "quiescence" are equivalent to the "movement" (phenomenal activities) and the "stillness" in Sengzhao's "Wu bu qian lun". It can be seen that while emphasising that Function and quiescence are two aspects of the same Reality and thus are inseparable and not different from each other, Sengzhao also indicated that Reality and Function are non-dual.

What, then, is Reality like in Sengzhou's thought? And, how did he understand the non-duality of Reality and Function? The answers to these two questions are to be found in Sengzhao's explanation of why the two seemingly contrary aspects of things, stillness/quiescence and movement/Function, share the same Reality. By resorting to the Madhyamaka differentiation of ultimate (zhendi 真諦; 
paramārtha-satya) and conventional truths (sudi 俗諦; samvrti-satya),78 in "Wu bu qian lun" Sengzhao further stated: "To discuss the [ultimate] truth, there is the expression of 'not shifting'; to guide worldly people [away from the belief that things are eternal], there is the expression of 'flowing and moving'” (談真有不遷之 稱, 導俗有流動之說). ${ }^{79}$ This expresses the view that in order to make ordinary people aware of the impermanence of things, we can provisionally say that things flow and move in terms of conventional truth. However, this flowing and moving reveals the ultimate truth that things do not shift. While presenting the "not moving"/"not shifting"/"stillness" of things by demonstrating that things can remain only at their moment of occurrence but not move to another moment of occurrence, in "Wu bu qian lun" Sengzhao also indicated that to say things "stay" or "remain" (zhu 住) does not mean that things really abide but rather means that things are not permanent, since they have provisional natures that abide only at one division of time (各性住於一世) - past, present or future. 80 Therefore, the only thing that is constant is the impermanence or ultimate emptiness of things, which is ontological Reality.

According to Sengzhao's above view, Reality is not different from the phenomenal world, its Function, since the various phenomena - either their real nature (the "not moving"/"not shifting"/"still"/"quiescent") or their appearances

\footnotetext{
${ }^{78}$ Like Yogācāra, Madhyamaka is also an influential school of Indian Buddhism. Generally, "ultimate truth" refers to the view of reality as experienced by enlightened people. It transcends dualistic logic and is apart from linguistic constructions. "Conventional truth" is the reality perceived by unenlightened people, and is expressed readily in dualistic linguistic constructions. See the Digital Dictionary of Buddhism, ed. A. Charles Muller, available at: http://www.buddhism-dict.net/ddb/, under the entry “二諦”. However, the understanding of the two truths differs between Buddhist schools. For a discussion of the two truths in Madhyamaka philosophy, see Hans-Rudolf Kantor, "Concepts of Reality in Chinese Mahāyāna Buddhism", in Chinese Metaphysics and Its Problems, eds. Chenyang Li and Franklin Perkins, Cambridge: Cambridge University Press, 2015, pp. 133-138. For a discussion of the two truths in another philosophical school rather than Madhyamaka, see, for example, Dan Lusthaus, "The Two Truths (Samvrrti-satya and Paramārtha-satya) in Early Yogācāra", Journal of Buddhist Studies, vol. VII, 2010, pp. 101-152.

${ }^{79}$ Sengzhao, "Wu bu qian lun", 0151a20.

80 Ibid.
} 
(the "flowing and moving") - reveal the impermanence of things (Reality). Impermanence is constant, but this constancy is not separate or apart from phenomenal "flowing and moving". Thus, as Tang Yongtong pointed out, Sengzhao's thought can be summarised as the view that "it is precisely Reality that is Function" (ji ti ji yong 即體即用), and the idea that “it is precisely the moving that is the still" (ji dong ji jing 即動即靜) in the “Wu bu qian lun” demonstrates this view.81

Sengzhao's view has a clear connection with Madhyamaka Buddhism. According to Tang Yongtong, although Sengzhao integrated ideas from both Buddhism and xuanxue, his thought in the "Wu bu qian lun" was drawn substantially from his teacher Kumārajīva (Jiumoluoshi 鳩摩羅什, 344-413), ${ }^{82}$ in whose writings the view that both the still and the moving are subsumed within the same Reality had already appeared. 83 As Wing-tsit Chan related, it was Kumārajiva who introduced the Madhyamakan ideal of absolute or ultimate emptiness into China, and Sengzhao applied this doctrine in his "Wu bu qian lun". Sengzhao also prepared the ground for Jizang 吉藏 (549-623), a Buddhist monk who elaborated on the Madhyamaka doctrine and developed the Three Treatise School (Sanlun zong 三論宗), a Chinese Buddhist school that derived from Indian Madhyamaka Buddhism. ${ }^{84}$ Therefore, Sengzhao's thought can be said to have influenced not only the Three Treatise School but also the way in which Indian Madhyamaka Buddhism was interpreted in China.

Jizang inherited Sengzhao's Madhaymakan-inflected perspective that Reality and Function are not different:

以體爲用，以用爲體，體用平等，不二中道，方是佛性。 85

\footnotetext{
81 Tang, Han Wei LiangJin NanBeichao fojiao shi, pp. 333-334.

82 Kumārajīva was one of the greatest translators of Buddhist texts into Chinese, and a specialist in Madhyamaka philosophy.

83 See Tang, Han Wei LiangJin NanBeichao fojiao shi, pp. 333-339.

84 Chan, A Source Book in Chinese Philosophy, p. 344.

85 Jizang 吉藏, Dasheng xuan lun 大乘玄論 (On the profound meanings of Mahāyāna), vol. 3, in the CBETA edition of the Taishō Tripițaka, T45n1853_003, 0038b08.
} 
To take Reality as Function and Function as Reality, Reality and Function are undifferentiated. This middle path of non-duality is precisely the buddha-nature.

In this statement, Jizang asserts that Reality and Function are "non-dual" (bu'er 不 二) and interprets this idea by presenting Reality and Function as undifferentiated.

In Jizang's era, the sixth-century Sinitic Buddhist work, Dasheng qi xin lun 大 乘起信論 (Treatise on giving rise to faith in the Great Vehicle), ${ }^{86}$ became an important text for presenting another version of the view that Reality and Function are non-dual:

摩訶衍者, 總說有二種。云何為二? 一者法, 二者義。所言法者, 謂 眾生心。是心則攝一切世間法出世間法, 依於此心顯示摩訶衍義。何 以故? 是心真如相, 即示摩訶衍體故。是心生滅因緣相, 能示摩訶衍 自體相用故。所言義者，則有三種。云何爲三? 一者體大，謂一切法 真如平等不增減故。二者相大, 謂如來藏具足無量性功德故。三者用 大, 能生一切世間出世間善因果故, 一切諸佛本所乘故, 一切菩薩皆 乘此法到如來地故。87

Generally speaking, there are two aspects of Mahāyāna. What are the two? The first is the dharma, and the second is the meaning. What is

\footnotetext{
86 This text is considered to have been composed by the early Indian Buddhist thinker Aśvaghoṣa (Maming 馬鳴, ?-?) and translated for the first time in the sixth century by Paramārtha (Zhendi 真 諦, 499-569), an Indian monk who went to China in the Liang dynasty and became a great translator of Buddhist sutras in Chinese Buddhist history. However, these attributions have been subject to dispute. It has long been accepted that the text was not composed by Aśvaghoșa, and today most scholars maintain that it is not an Indian Buddhist work but a Chinese product. The identity of Paramārtha as the translator has also been called into question. For further discussions, see, for example, Gao Zhennong 高振農, “Xuyan” 序言 (Preface), Dasheng qi xin lun jiaoshi 大乘起信論校 釋 (Collation and annotation of the Treatise on Giving Rise to Faith in the Great Vehicle), Beijing: Zhonghua shuju, 1992, pp. 1-7, 18-20. Despite these controversies, the significant influence of this text on later Chinese Buddhist schools and even Confucian schools has been revealed by more and more scholars. For an introduction to the Dasheng qi xin lun, see John Makeham, "Introduction", in Transforming Consciousness, ed. John Makeham, p. 7.
}

87 Gao, Dasheng qi xin lun jiaoshi, p. 12. 
called "dharma" refers to the mind of sentient beings. This mind includes all mundane and supramundane dharmas, ${ }^{88}$ and based on this mind the truth of Mahāyāna is revealed. For what reason? Because this mind in its aspect of suchness (tathatā $)^{89}$ reveals the reality of Mahāyāna, and it in its aspect of arising and ceasing according to causes and conditions can then reveal the reality, characteristics, and function of Mahāyāna. As for what is called "meaning", there are three kinds. What are the three? The first is the greatness of its reality, because the suchness of all dharmas is equal, neither increasing nor decreasing. The second is the greatness of its characteristics, because the store of the tathāgata is fully endowed with uncountable merits. The third is the greatness of its function, because it is able to generate all causes and effects of good deeds, both mundane and supramundane, all the buddhas have always ridden on it, and all the bodhisattvas ride on this truth to the stage of tathägata.

In this passage, both Reality and phenomena are subsumed within the mind of sentient beings, which is also called the One Mind (yixin 一心) in the Dasheng qi xin Iun. ${ }^{90}$ This mind has two aspects. The aspect of the mind of suchness is ontological Reality. It is the inherent nature of the mind and thus is the true mind. It equally pervades all dharmas, neither increasing nor decreasing. The aspect of the mind of arising and ceasing is the combination of Reality and phenomena. It represents the adaptation of the mind of suchness to phenomenal conditions. Phenomena are the

\footnotetext{
88 "Dharma" ( $f a$ 法) is a Buddhist term that can be used to refer to anything, including both the conditioned (factors, feelings, empty space, etc.) and the uncondtioned (suchness/nirvāṇa).

89 Suchness (zhenru 真如; tathatā) is a fundamental concept in Mahāyāna Buddhism. Generally, it means "the nature of things as they truly are" and refers to the ultimate truth of all phenomena, although different Buddhist schools may have different interpretations of it. For an explanation of the term zhenru, see, for example, Wu Rujun 吳汝鈞, Weishi xianxiangxue: Shiqin yu Hufa 唯識現象 學：世親與護法 (Yogācāra phenomenology: Vasubandhu and Dharmapāla), Taibei: Taiwan xuesheng shuju, 2002, pp. 212, 237-238.

90 See Gao, Dasheng qi xin lun jiaoshi, p. 16.
} 
activities of the mind; they arise and cease, are subject to causes and conditions, and are therefore impermanent. As John Makeham points out, suchness exists in the aspect of the mind of arising and ceasing while simultaneously extending beyond the aspect of the mind of arising and ceasing, just as wetness exists in all waves but simultaneously extends beyond any particular wave. ${ }^{91}$ When suchness adapts to phenomenal conditions, although it is not the same as phenomena because it remains unchanged and undefiled, it is also not different from them, since it merges seamlessly with them. ${ }^{92}$ Under this situation, Reality (suchness) and Function (phenomena) are non-dual. This kind of non-duality of Reality and Function, achieved through subsuming both within the mind of sentient beings, is obviously different from Sengzhao's and Jizang's perspectives, which directly equate Reality with Function.

The idea that suchness and phenomenal activities are subsumed within the mind is classified as the tathāgatagarbha (rulaizang 如來藏; the store of buddhas) system - all dharmas are grounded in one mind that is intrinsically pure and enlightened, which can be traced back to very early Buddhist sutras in India and was inherited by the Dasheng qi xin lun in China. ${ }^{93}$ This idea in the Dasheng qi xin lun has been significant for Chinese philosophy, and it has had a great influence on the views of Reality and Function in such Chinese Buddhist schools as Huayan. As Peter N. Gregory relates, this idea provided the basis on which the Huayan theory

\footnotetext{
91 John Makeham, "Introduction", in The Buddhist Roots of Zhu Xi's Philosophical Thought, ed. John Makeham, New York: Oxford University Press, 2018, p. 30; "Monism and the Problem of the Ignorance and Badness in Chinese Buddhism and Zhu Xi's Neo-Confucianism”, ibid., p. 320.

92 For a detailed discussion of these ideas in the Dasheng qi xin lun, see Makeham, "Introduction", The Buddhist Roots of Zhu Xi's Philosophical Thought, ed. John Makeham, pp. 13, 30; "Monism and the Problem of the Ignorance and Badness in Chinese Buddhism and Zhu Xi's Neo-Confucianism", pp. 281-282, 321, 322 .

93 See Peter N. Gregory, "The Vitality of Buddhism in the Sung”, in Buddhism in the Sung, eds. Peter N. Gregory and Daniel A. Getz, Jr., Honolulu: University of Hawai'I Press, 1999, p. 7; Mou Zongsan 牟 宗三, “Fojia ti yong yi zhi hengding” 佛家體用義之衡定 (A judgment of the meaning of ti-yong in Buddhism), Xinti yu xingti 心體與性體 (Reality of the mind and of human nature), Taibei: Zhengzhong shuju, 1968-1969, vol. 1, pp. 576-579.
} 
of "nature origination" (xing qi 性起) was developed, according to which all phenomenal appearances (Function) are believed ultimately to originate from the nature, a synonym for the intrinsically pure and enlightened one mind (suchness or the tathägatagarbha, that is, Reality) of the Dasheng qi xin lun. ${ }^{94}$

Moreover, Fazang 法藏 (643-712), a Buddhist monk in the Tang dynasty (618-907) who is considered to be the third Huayan patriarch and who was a prominent commentator on the Dasheng qi xin lun, drew on this line of thought for his understanding of Reality and Function. According to Gregory, Fazang described the conditioned origination from the tathāgatagarbha (rulaizang yuanqi 如來藏緣 起) as elucidating the "harmonious interaction of the absolute and the phenomenal without obstruction" (li shi rongtong wu'ai 理事融通無礙), which Fazang explained in terms of the two aspects of the one mind taught in the Dasheng qi xin lun. Fazang identified the absolute (li 理) with the mind as suchness and the phenomenal (shi 事) with the mind subject to arising and ceasing. ${ }^{95}$ Based on this understanding, Fazang directly expressed his view that Reality and Function are interpenetrating and not different from each other:

事雖宛然, 恆無所有, 是故用即體也。如會百川以歸於海。理雖一味, 恆自隨緣, 是故體即用也。如舉大海以明百川。由理事互融, 故體用 自在。96

Although phenomena seem real, they are constantly devoid of anything. Therefore, Function is precisely Reality. This is like converging hundreds of rivers into the sea. Although the absolute is only one, it constantly accords with conditions [to manifest itself as phenomena]. Therefore, Reality is precisely Function. This is like talking about the

\footnotetext{
94 Gregory, "The vitality of Buddhism in the Sung", p. 7.

95 Peter N. Gregory, Tsung-mi and the Sinification of Buddhism, Princeton: Princeton University Press, 1991, p. 157.

96 Fazang 法藏, Huayanjing yihai baimen 華嚴經義海百門 (One hundred categories of the many meanings in the Huayan Sutra), in the CBETA edition of the Taishō Tripitaka, T45n1875_001, $0635 \mathrm{a} 03$.
} 
sea to reveal the hundreds of rivers. Because the absolute and the phenomenal penetrate each other, then Reality and Function are unimpeded [by each other].

The reason that phenomena "are constantly devoid of anything" is because their appearance is simply the coming together of causes and conditions. They are not real entities because they lack self-nature. Based on this "fact", that which permeates the whole phenomenal world is actually their Reality, that is, the absolute, or suchness. Therefore, Fazang claimed that Function (the phenomenal) is Reality (the absolute). Also, Reality/the absolute constantly manifests itself as various phenomena in accordance with conditions and, thus, those phenomena are nothing but the expression of Reality/the absolute. Therefore, Fazang claimed that Reality is Function. This statement explicitly shows Fazang's interpretation of the idea that Reality and Function are non-dual.

In the same era as Fazang, another famous Buddhist monk Xuanzang 玄牀 (602-664) initiated the development of Yogācāra Buddhism in China by translating and commentating on its key texts. ${ }^{97}$ Yogācāra Buddhism maintains that the external world we perceive is actually the working of our mind. ${ }^{98}$ For Yogācāra, suchness has no connection with the generation of the phenomenal world, and the various phenomena are by no means the expression of Reality. ${ }^{99}$ This view differs

\footnotetext{
97 See Tang Yongtong, Sui Tang fojiaoshi gao 隋唐佛教史稿 (A manuscript on the Buddhist history of the Sui-Tang period), Beijing: Zhonghua shuju, 1982, pp. 141-145; Pan Guiming 潘桂明, Zhongguo fojiao sixiangshi gao 中國佛教思想史稿 (A manuscript on the intellectual history of Chinese Buddhism), Nanjing: Jiangsu renmin chubanshe, 2009, vo. 2, pp. 293-308.

98 This does not mean that the mind exists alone. Rather, it means that what appears to us is constructed, projected and interpreted by our mind. Thus, many scholars believe that Yogācāra represents an epistemological, rather than an ontological, position. For a statement of this position, and further references to scholarship on the subject, see Makeham, "Introduction", in Transforming Consciousness, ed. John Makeham, pp. 22-23.

99 See Wu Rujun, “Weishizong zhuan shi cheng zhi lilun zhi yanjiu” 唯識宗轉識成智理論之研究 (A study on the Yogācāra theory of "the transformation of consciousness into wisdom"), in his Fojiao de gainian yu fangfa 佛教的概念與方法 (On Buddhist concepts and methods), Taibei: Taiwan shangwu yinshuguan, 1988, pp. 146-147. This point will be discussed in more detail later in this chapter.
} 
markedly from Fazang's thought. According to the modern philosopher Jiang Weiqiao 蔣維喬 (1873-1958), Fazang was dissatisfied with Xuanzang's view, and one of the reasons for this is Fazang's belief that the unification and inseparability of suchness and the myriad phenomena was not thoroughly explicated in Yogācāra. Drawing on the Dasheng qi xin lun, Fazang then opposed what Xuanzang had advocated. ${ }^{100}$ Gregory further presented a deeper reason for this issue. According to him, Huayan's insistence that the phenomenal world is the manifestation of Reality was based on a commitment to fashion an ontology that affirms the phenomenal word of human endeavour, and this was the primary reason the Huayan school rejected Xuanzang's Yogācāra. ${ }^{101}$ Above all, Fazang's perspective on Reality and Function and his support for the Dasheng qi xin lun is consistent with his objection to Xuanzang's Yogācāra and reveals the confrontation between the tathāgatagarbha doctrine and Xuanzang's Yogācāra on the issue of the relationship between Reality and the phenomenal world.

Fazang was one of the significant figures in Buddhism during the Sui-Tang period (581-907), a period in which Buddhism achieved great prominence in China. In this period, there were nonetheless many other Buddhist approaches to the issue of the relationship between the ontological and the phenomenal in addition to Fazang's statement. As in Fazang's statement, the ti-yong paradigm was also often used as a principle for organising and classifying doctrines and ideas in these Buddhist approaches, and the view that Reality and Function are non-dual was greatly developed by the various schools of Buddhism at the time. The vitality of Buddhism, in particular Tiantai 天台 and Chan 禪, extended into the Song dynasty, although Neo-Confucianism sprang up to challenge Buddhism. ${ }^{102}$

\footnotetext{
100 Jiang Weiqiao 蔣維喬, Zhongguo fojiaoshi 中國佛教史 (Chinese Buddhist history), Changsha: Yuelu shushe, 2010, pp. 149, 200.

101 Gregory, Tsung-mi and the Sinification of Buddhism, p. 110.

102 Some scholars hold that the predominance of Buddhist thought lasted only until the late Tang, after which it began to decline. See, for example, Tang, Sui Tang fojiaoshi gao, p. 294. However, in recent studies some scholars argue that, rather than being a stage in which Buddhism was in a state
} 


\subsubsection{Reality and Function in Neo-Confucianism}

In the history of Chinese philosophy, the relationship between Reality and Function is also very conspicuous in Neo-Confucian thought. Neo-Confucians can be categorised into three schools: the School of Vital Stuff (qixue 氣學), represented by Zhang Zai and Wang Fuzhi; the School of Principle (lixue 理學), represented by Cheng Yi and Zhu Xi; the School of Mind (xinxue 心學), represented by the Southern Song thinker Lu Jiuyuan 陸九洣 (1139-1193) and the Ming philosopher Wang Yangming 王陽明 (1472-1529). ${ }^{103}$ Each of these schools has its own perspectives on the relationship between Reality and Function. The following will in turn discuss the representative views on this issue in these three Neo-Confucian schools.

In the School of Vital Stuff, Zhang Zai presented the "great void" (taixu 太虛) and “vital stuff” ( $q i$ 氣) - or the state of vital stuff when it disperses (san 散) and the state of vital stuff when it gathers ( $j u$ 聚) - as Reality and Function, respectively. In his representative work, Zheng meng 正蒙 (Correction of youthful ignorance), he considered vital stuff to be the source of all phenomena, and believed that the generation and extinction of various phenomena were merely the changing states of vital stuff: "When the materialised vital stuff disperses, it passes into a formless [state], and it just achieves its Reality; when [the formless vital stuff] gathers, it turns to a [state] with images, yet it does not lose its constant [nature]" (氣之爲物, 散入無形, 適得吾體; 聚爲有象, 不失吾常). ${ }^{104}$ Since phenomena are only a particular state of vital stuff, Zhang conceived phenomena and vital stuff to be the

of decline, the Song dynasty was in fact a period of great efflorescence in Buddhism. See Gregory, "The Vitality of Buddhism in the Sung", pp. 1-20; Mark Halperin, Out of the Cloister: Literati Perspectives on Buddhism in Sung China, 960-1279, Cambridge, Mass.: Harvard University Asia Centre, 2006, pp. 7-12.

103 See Xiang Shiling 向世陵, Li qi xing xin zhijian: Song Ming lixue de fenxi yu sixi 理氣性心之間一 一宋明理學的分系與四系 (Between principle, vital stuff, human nature, and the mind: the division and the four systems of Song-Ming Neo-Confucianism), Beijing: Renmin chubanshe, 2008, pp. 213232.

104 Zhang Zai 張載, Zheng meng 正蒙 (Correction of youthful ignorance), in Zhang Zai ji 張載集 (Collected works of Zhang Zai), Beijing: Zhonghua shuju, 1978, p. 7. 
same thing. Based on this understanding, he then presented the great void as Reality, that is, the formless state of vital stuff. For example, he said: "The great void is formless, and it is the fundamental Reality of vital stuff” (太虛無形，氣之本體). ${ }^{105}$ Also, Zhang directly used the terms ti and yong to refer to the great void and vital stuff. 106

With regard to the relationship between Reality/the great void and Function/vital stuff/phenomena, Zhang stated:

太虛不能無氣, 氣不能不聚而爲萬物, 萬物不能不散而爲太虛。循是 出入, 是皆不得已而然也。107

The great void cannot be without vital stuff, vital stuff cannot but gather and then become the myriad things, and the myriad things cannot but disperse and then become the great void. Following this sequence of gathering and dispersal is inevitable for all things.

This again shows that the great void, vital stuff and the myriad phenomena are a single whole: the great void and the myriad phenomena are subsumed within vital stuff as its two different kinds of state. As Jeeloo Liu puts it, in Zhang Zai's philosophy, the great void is the Reality of vital stuff, which is indivisible and formless; the things in the phenomenal world are the manifestations of vital stuff, and they are where the function of vital stuff is revealed. ${ }^{108}$ In this way, Zhang presented Reality and Function as non-dual.

Zhang Zai further demonstrated his view that Reality/the great void and Function/vital stuff are non-dual by rejecting the view which differentiates "the

\footnotetext{
105 Ibid.

106 See ibid., p. 8. For a detailed discussion of the great void and vital stuff in Zhang Zai's metaphysics, see Robin R. Wang and Ding Weixiang, "Zhang Zai's Theory of Vital Energy", in Dao Companion to Neo-Confucian Philosophy, ed. John Makeham, New York: Springer, 2010, pp. 46-50.

107 Zhang Zai, Zheng meng, p. 7.

108 Jeeloo Liu, "Wang Fuzhi's Philosophy of Principle ( $\mathrm{Li}$ ) Inherent in Qi", in Dao Companion to NeoConfucian Philosophy, ed. John Makeham, p. 357.
} 
absence of characteristics" and "that which has characteristics":

知虛空即氣, 則有無、隱顯、神化、性命通一無二。……若謂虛能生氣, 則虛無窮, 氣有限, 體用殊絕, 入老氏 “有生於無” 自然之論, 不識 所謂有無混一之常。109

If one understands that the void space [the great void] is not different from vital stuff, then [one will know that] that which has characteristics and the absence of characteristics, the hidden and the manifest, numinosity and change, the nature and command, are completely one and the same thing, rather than two. ... If it were said that the [great] void is able to generate vital stuff, then the void would be infinite, vital stuff would be finite, and Reality and Function would be severed. This would be to side with Laozi's cosmological thesis that "that which has characteristics is generated by the absence of characteristics", failing to understand the so-called constant norm that "that which has characteristics" and "the absence of characteristics" are a unity.

氣之聚散於太虛, 猶冰凝釋於水, 知太虛即氣, 則無無。……諸子淺 妄, 有有無之分, 非窮理之學也。110

The gathering and dispersing of vital stuff in the great void is like ice's freezing from and melting into water. If one understands that the great void is not different from vital stuff, then [one should know that] there is no "absence of characteristics". ... [There have been] various thinkers who are shallow and preposterous, [as] they differentiate between "that which has characteristics" and "the absence of characteristics", which is not the kind of learning that probes into the truth.

According to these two passages, it is not the case that the great void as Reality generates vital stuff as Function such that the two are ontologically distinct. Rather,

\footnotetext{
109 Zhang Zai, Zheng meng, p. 8.
}

110 Ibid., pp. 8-9. 
as Zhang emphasised with the metaphor of ice and water, the great void is the intrinsic reality of vital stuff and thus is not different from vital stuff. As such, there is actually no "absence of characteristics" that can be differentiated from "that which has characteristics".

Wang Fuzhi valued Zhang Zai's Zheng meng highly. ${ }^{111}$ In his Zhangzi Zheng meng zhu 張子正蒙注 (An annotation of Zhang Zai's Correction of Youthful Ignorance), Wang similarly maintained that the great void, as Reality, and vital stuff, as Function, are non-dual:

人之所見爲太虛者, 氣也, 非虛也。虛涵氣, 氣充虛, 無有所謂無者。 112

What people see as the "great void" is vital stuff, rather than the [great] void. The [great] void contains vital stuff, and vital stuff fills the [great] void. [As such,] there is no so-called "absence of characteristics".

太虛即氣，絪縕之本體。113

The great void is vital energy, and it is the fundamental Reality of yinyun.

In Wang's metaphysics, the term yinyun 絪縕 is used to describe the primal situation in which vital stuff has not been divided into yin 陰 and yang 陽. 114 The above quotations clearly show that in Wang's view, the great void and vital stuff are non-dual.

Unlike the above understanding of Reality and Function by the School of Vital Stuff, the School of Principle presents "principle" (li 理), which is inherent in phenomena, as Reality. ${ }^{115}$ As for the relationship between Reality/principle and

\footnotetext{
111 See Wang Fuzhi 王夫之, Zhangzi Zheng meng zhu 張子正蒙注 (An annotation of Zhang Zai's Correction of Youthful Ignorance), in Chuanshan quanshu 船山全書 (The complete works of Chuanshan), Changsha: Yuelu shushe, 1988-1996, vol. 12, pp. 9-13.

112 Ibid., p. 30.

113 Ibid., p. 32.

114 See, for example, ibid., p. 35.

115 For a general introduction to the ideas of principe by the School of Principle, see Zhang Dainian,
} 
Function/phenomena, Cheng Yi in his “Yi zhuan xu” 易傳序 (Preface to Cheng Yi's Annotation of the Book of Change) presented his celebrated statement, which advocates the oneness of the two:

至微者理也，至著者象也。體用一源，顯微無間。116

That which is extremely subtle are principles, and that which is extremely apparent are images. Reality and Function are a single source; there is no gap between the apparent and the subtle.

This statement was presented by Cheng Yi in his late years and intensively reflects his core ideas. ${ }^{117}$ According to its context, this was originally presented by Cheng Yi to illuminate the relationship between the explanation ( $c i$ 辭) and the image (xiang 象) of any hexagram (gua 卦) in Zhouyi. In Zhouyi, both the explanation and the image refer to the same thing, that is, the hexagram: the image is the expression of the hexagram; the explanation is the underlying principle of the image. Since those images of the various hexagrams in Zhouyi are actually symbols that represent the myriad things in the universe, Cheng's statement can also be understood as an illustration of the relationship between various phenomena and their principles.

It can be seen that in Cheng Yi's view, principles/Reality and phenomena/Function are non-dualistic: the former are the inherent principles of

Zhongguo gudian zhexue gainian fanchou yaolun, pp. 42-43. For a detailed discussion of the view of principle by Zhu Xi, the most representative figure of this school, see Makeham, "Monism and the Problem of the Ignorance and Badness in Chinese Buddhism and Zhu Xi's Neo-Confucianism”, pp. 277-344; Brook A. Ziporyn, “The Ti-Yong 體用 Model and Its Discontents: Models of Ambiguous Priority in Chinese Buddhism and Zhu Xi's Neo-Confucianism", in The Buddhist Roots of Zhu Xi's Philosophical Thought, ed. John Makeham, pp. 193-276.

116 Cheng Yi 程頣, “Yi zhuan xu” 易傳序 (Preface to Cheng Yi's Annotation of the Book of Change), Zhouyi Chengshi zhuan 周易程氏傳 (Cheng Yi's annotation of the Book of Change), Beijing: Zhonghua shuju, 2011, p. 1.

117 Peng Yaoguang 彭耀光, “Cong 'ti yong yiyuan, xian wei wujian' kan Cheng Yi lixue de jingshen” 從 “體用一源, 顯微無間” 看程頣理學的精神 (To see the spirit of Cheng Yi’s learning of principle from his "Reality and Function are a single source; there is no gap between the apparent and the subtle"), Dongyue luncong 東岳論叢, vol. 32, no. 8, August 2011, p. 45. 
the latter, and the latter are the external appearances of the former. As a matter of fact, Cheng Yi believed that all specific principles of various things were actually the same principle. For him, this common principle is universal truth, universal order, and universal law, which is shared and possessed by everything in the world. ${ }^{118}$ Accordingly, there is only one principle, which has many different phenomena as its manifestation. Above all, the ontological and the phenomenal cannot be divided into two distinct realms.

Cheng's view that all phenomena (Function) are the expression of their shared principle (Reality) seems to be consistent with the Huayan doctrine of "the unobstructed interpenetration of the absolute and the phenomenal" (li shi wu'ai 理 事無礙). For example, as discussed earlier in this chapter, Fazang explained this doctrine to mean that the absolute (Reality) constantly manifests itself as various phenomena (Function) in accordance with conditions such that those phenomena are nothing but the expression of the absolute. This shares some similarities with Cheng's view. Also, Cheng once even used the character shi 事, which was employed by the Huayan School to refer to the phenomenal, to replace xiang 象 when expressing his above view that the subtle/principle/Reality and the apparent/images/Function are "a single source" (yiyuan 一源):

至顯者莫如事，至微者莫如理; 而事理一致，微顯一源。119

As for that which is extremely apparent, nothing can be compared with phenomena; as for that which is extremely subtle, nothing can be compared with principle. Indeed, phenomena and principle are unified, and the subtle and the apparent are a single source.

The use of this pair of terms, li and shi, seems to echo its use by earlier Buddhist scholars, which suggests a connection between Cheng Yi and Huayan Buddhism.

\footnotetext{
118 See Chan, A Source Book in Chinese Philosophy, p. 519.

119 Cheng Hao 程影 and Cheng Yi, Henan Chengshi yishu 河南程氏遺書 (Posthumous writings of Henan's Cheng Hao and Cheng Yi), vol. 25, p. 7, in ErCheng quanshu 二程全書 (The complete works of Cheng Hao and Cheng Yi), Shanghai: Zhonghua shuju, 1927-1936.
} 
Accordingly, there is a possibility that Cheng's view on Reality and Function drew on Huayan philosophy. ${ }^{120}$ As mentioned previously, the Huayan school was influenced by the Dasheng qi xin lun, and Fazang drew on the idea that the mind of sentient beings has two aspects in this text to elucidate his own understanding of Reality and Function. Thus, there is also a possibility that Cheng was influenced (directly or indirectly) by the Dasheng qi xin lun.

Cheng Yi's statement that "Reality and Function are a single source; there is no gap between the apparent and the subtle" was subsequently interpreted and developed by Zhu Xi. Zhu once noted:
蓋自理而言，則即體而用在其中，所謂“一原”也；自象而言，則即 顯而微不能外，所謂 “無間”也。121

From the perspective of principle, with respect to Reality, Function inheres within it. This is what [Cheng Yi] means by the "single source". From the perspective of images, with respect to the apparent, the subtle cannot be outside [of it]. This is what [he] means by "no gap".

Through interpreting Cheng's statement, Zhu expressed his view that principle/Reality/the subtle and images/Function/the apparent are inherent in each other so that the two are "a single source", and there is "no gap" between them. It can be seen that here Zhu's interpretation is basically consistent with Cheng's

\footnotetext{
120 There have been scholars who also argue that Cheng Yi's view of Reality and Function was possibly influenced by Huayan Buddhism. For example, Wing-tsit Chan pointed out that the idea that "principle is one but its manifestations are many" probably came from Buddhism, particularly the Huayan School, because of its similarity to the Huayan doctrine of the harmony of principle (li 理) and facts (shi 事). Chan, A Source Book in Chinese Philosophy, p. 544. Also, the contemporary scholar Zhang Xiaojian 張曉劍 demonstrates the influence of Huayan Buddhism not only on Cheng Yi but also on the School of Principle as a whole, and he argues that the thought of Reality and Function in the School of Principle had not broken through that of Huayan Buddhism. See Zhang Xiaojian 張曉 劍, “Huayan zong ti yong lun ji qi dui lixue ti yong lun de kaiqi” 華嚴宗體用論及其對理學體用論的 開啓 (The thought of Reality and Function of the Huayan School and its inspiration on that of the School of Principle), Xueshu yuekan 學術月刊, vol. 40, no. 10, October 2008, pp. 56-63.

121 Zhu Xi 朱喜, “Da Wang Shangshu” 答汪尚書 (Reply to Minister Wang), in Zhuzi daquan 朱子大

全 (The complete works of Zhu Xi), Shanghai: Zhonghua shuju, 1927-1936, vol. 30, p. 13.
} 
thought and again gives expression to the non-duality of Reality and Function.

In addition to the passage quoted above, Zhu also interpreted and developed Cheng's statement elsewhere:

體用一源者, 自理而觀, 則理爲體, 象爲用, 而理中有象, 是一源也; 顯微無間者, 自象而觀, 則象爲顯, 理爲微, 而象中有理, 是無間也。 先生後答語意甚明, 子細消詳便見歸著。且既曰有理而後有象, 則理 象便非一物。故伊川但言其一源與無間耳，其實體用顯微之分則不能 無也。今曰理象一物, 不必分別, 恐陷於近日含胡之弊, 不可不察。 122

As for the proposition that "Reality and Function are a single source", from the perspective of principle, then principle is Reality, images are Function, and principle has images within it, which is "a single source". As for the proposition that "there is no gap between the apparent and the subtle", from the perspective of images, then images are the apparent, principle is the subtle, and images have principle within them, which is "no gap". The meaning of Master [Cheng Yi]'s reply is quite explicit. If one carefully ponders [his reply], then one will see where it leads to. Further, since it is said that there are images only after there is principle, then principle and images in that case are not the same thing. Therefore, although Yichuan 伊川 [i.e. Cheng Yi] said that they were a single source and that there was no gap between them, the fact is, there must be a differentiation between Reality/the subtle and Function/the apparent. Now, to say that principle and images are the same thing and that it is unnecessary to differentiate them, then I am afraid that this will fall into the error of confusion of recent days. This must be investigated.

The first half of this passage still expresses Zhu's opinion that principle/Reality/the

122 Zhu Xi, “Da He Shujing” 答何叔京 (Reply to He Shujing), ibid., vol. 40, p. 39. 
subtle and images/Function/the apparent are inherent in each other and thus are "a single source" and "without gap". Yet, in the second half of the passage, Zhu further emphasised that the so-called "single source" and "no gap" did not indicate in any way that the two are identical. For Zhu, principle is the intrinsic nature, the most essential, while images are only that which manifests it. Thus, although they can never exist without each other temporally, principle can be said to be conceptually prior to images. ${ }^{123}$ The two passages quoted above are only two examples that show how Zhu expressed his view of the non-duality of Reality and Function by interpreting Cheng Yi's statement. However, as Chen Lai demonstrates, Zhu's thought underwent a complicated process of development, and his discussions of the relationship between principle and vital stuff (for Zhu, vital stuff is the material that forms the images, appearances or physical forms of the phenomenal world) ${ }^{124}$ were often in terms of different issues and even presented from different angles. ${ }^{125}$

Like Cheng Yi and Zhu Xi, Lu Jiuyuan also believed that there existed a single principle which pervades the universe. Lu further related this principle to the human mind:

人皆有是心，心皆具是理，心即理也。126

Everyone has this mind, and this mind [of each person] possesses this principle. The mind is not different from the principle.

123 Zhu's understanding of principle and images here is consistent with his view of the relationship between principle and vital stuff. See Ziporyn, “The Ti-Yong 體用 Model and Its Discontents”, pp. 236-248; John Berthrong, “Zhu Xi's Cosmology”, in Dao Companion to Neo-Confucian Philosophy, ed. John Makeham, pp. 161-162.

124 Feng Youlan 馮友蘭, Zhongguo zhexue jianshi 中國哲學簡史 (A brief history of Chinese philosophy), Beijing: Beijing daxue chubanshe, 1996, p. 255. For an introduction to Zhu Xi's understanding of vital stuff, see, also, Berthrong, "Zhu Xi's Cosmology", p. 161.

125 See Chen Lai, Zhu Xi zhexue yanjiu 朱喜哲學研究 (A study on Zhu Xi's philosophy), Beijing: Zhongguo shehui kexue chubanshe, 1988, pp. 3-29.

126 Lu Jiuyuan 陸九洣, “Yu Li Zai” 與李宰 (To Li Zai), in Xiangshan quanji 象山全集 (The complete works of Xiangshan), Shanghai: Zhonghua shuju, 1927-1936, vol. 11, p. 6. 
Lu believed that there was a common mind shared by everyone, and the principle was inherent in this common mind and, as a corollary, possessed by everyone's mind. Since the principle is in the human mind, the latter can actually take the role of the former, which, as mentioned previously, is the "universal truth", "universal order", and "universal law" underlying everything in the universe. In this sense, the mind can be equated with principle.

Based on this view, Lu maintained that everything in the universe is subsumed within the mind and is an expression of the mind:

萬物森然於方寸之間, 滿心而發。充塞宇宙, 無非此理。127

The myriad things are replete in the mind and issue from the mind in its fullness. That which fills the universe is nothing but this principle.

According to this statement, the myriad things in the universe are contained in and issue from the mind. Since everything takes principle as its basis and is the expression of principle, then it can be said that this principle permeates the whole universe. Since, in Lu's view, principle is inherent within the mind such that the two are not different, then the universe can also be seen as the expression of the mind. Moreover, Lu directly identified the mind with the universe:

宇宙便是吾心, 吾心即是宇宙。千萬世之前, 有聖人出焉, 同此心, 同此理也; 千萬世之後, 有聖人出焉, 同此心, 同此理也; 東南西北 海有聖人出焉, 同此心, 同此理也。128

The universe is indeed my mind, and my mind is precisely the universe. Eons ago, a sage appeared, and he had this same mind and this same principle. Eons in the future, a sage will appear, and he will have this same mind and this same principle. No matter where sages appear, they have this same mind and this same principle.

\footnotetext{
127 Lu, "Yulu” 語錄 (Sayings), ibid., vol. 34, p. 21.

128 Lu, “Zashuo" 雜說 (Various discussions), ibid., vol. 22, p. 5.
} 
Through this passage, Lu expressed a view that there is only one "mind", one "principle", which exists eternally and unchangeably. Since things in all of time and space issue from the mind and are the expression of the mind, then the whole universe can be said to be equivalent to the mind.

Wang Yangming further developed Lu's thought, proposing that the human mind has a "spiritual luminosity" (lingming 靈明) called “innate moral knowledge" (liangzhi 良知), ${ }^{129}$ which is possessed not only by humans but also by every other thing in the universe. Wang considered this "innate moral knowledge" to be Reality: “innate moral knowledge is the fundamental Reality of the mind” (良知者, 心之本 體). ${ }^{130}$ Since the mind is equivalent to the universe, innate moral knowledge is indeed the Reality of the universe. For Wang, everything in the universe is formed on the basis of this shared innate moral knowledge, because of which the myriad things in the universe are indeed one body with human beings: ${ }^{131}$

$$
\begin{aligned}
& \text { 人的良知就是草木瓦石的良知。若草木瓦石無人的良知, 不可以爲草 } \\
& \text { 木瓦石矣。豈惟草木瓦石爲然, 天地無人的良知, 亦不可爲天地矣。 }
\end{aligned}
$$

129 The term liangzhi 良知 can be traced back to Mencius' “Jin xin” 盡心 (Exhausting the mind), in which it refers to something that is inherently possessed by humans and which "knows [what is morally right] without thinking” (bu lü er zhi 不慮而知). See Mengzi 孟子, “Jin xin zhangju, shang” 盡心章句上 (The chapter of “Exhausting the Mind”, A), in Jiao Xun 焦循, Mengzi zhengyi 孟子正義 (The correct meaning of the Book of Mencius), Shanghai: Zhonghua shuju, 1927-1936, vol. 26, p. 13. Although Cheng Hao also mentioned liangzhi in his "Shi ren pian" 識仁篇 (On understanding "benevolence"), he did not expound on this concept. See Cheng Hao, "Shi ren pian” 識仁篇 (On understanding “benevolence"), in “Mingdao xue'an” 明道學案 (The record of Mingdao), Zengbu Song Yuan xue'an 增補宋元學案 (The supplementary record of Song and Yuan scholars), eds. Huang Zongxi 黃宗羲 and others, Shanghai: Zhonghua shuju, 1927-1936, vol. 13, p. 4.

130 Wang Yangming 王陽明, Chuan xi lu 傳習錄 (Record on teaching and learning), Taibei: Zhengzhong shuju, 1954, p. 51.

131 The idea that the myriad things in the universe form one body can be traced back to Cheng Hao's idea that "benevolence, in some undifferentiated fashion, forms one body with the myriad things" (仁者, 渾然與萬物同體). See Cheng Hao, “Shi ren pian”, pp. 3-7. This idea can also be traced back further to Mencius' idea that “the myriad things are all possessed in oneself” (萬物皆備於我). See "Jin xin zhangju, shang", p. 5. For a detailed explanation of the idea that benevolence is one body with the myriad things, see Shimada, Zhongguo sixiangshi yanjiu, trans. Deng Hong, pp. 3-66. 
蓋天地萬物與人原是一體, 其發放之最精處, 是人心一點靈明。132

Humans' innate moral knowledge is indeed the innate moral knowledge of grass, trees, shards of pottery, and stones. If grass, trees, shards of pottery, and stones do not have humans' innate moral knowledge, then they cannot become grass, trees, shards of pottery, and stones. How can only grass, trees, shards of pottery, and stones be like this? If heaven and earth do not have humans' innate moral knowledge, then they cannot become heaven and earth either. This is because heaven, earth, and the myriad things are originally one body with humans. The most excellent part of their enlightenment is the little spiritual luminosity in the human mind.

Wang's statement shows that the innate moral knowledge of the human mind is indeed the shared basis on which the myriad things in the universe are able to become what they are. In this sense, the innate moral knowledge in Wang's philosophy is actually equivalent to the "principle" inherent in the human mind that underlies everything and by which everything is formed, presented in Lu Jiuyuan's philosophy. Yet, Wang further developed Lu's idea of principle so that, in his thought, this principle - that is, the "innate moral knowledge" in Wang's philosophy - becomes the Reality possessed not only by humans but also inherent in everything in the universe. ${ }^{133}$

The above are some influential and important ideas on Reality and Function in Buddhism and Neo-Confucianism before Xiong Shili. As discussed earlier in this thesis, in his early period before 1920, Xiong especially studied Neo-Confucian philosophy, and expressed some thoughts on Buddhism by discussing its ideas in

\footnotetext{
132 Wang Yangming, Chuan xi lu, pp. 89-90.

133 On Wang Yangming's view that humans and all othe things in the universe share the same basis, namely, the "spiritual luminosity" or "innate moral knowledge" in the human mind, see also David W. Tien, "Metaphysics and the Basis of Morality in the Philosophy of Wang Yangming", in Dao Companion to Neo-Confucian Philosophy, ed. John Makeham, pp. 304-305.
} 
his writings. Thus, it is natural that he was inspired by those ontological ideas of Reality and Function in these two schools. Indeed, Xiong had already started to ponder the relationship between the phenomenal world and its ontological Reality before 1920, as elaborated in the following section.

\subsection{Xiong's Reflections on the Ontological and the Phenomenal before 1920}

Xiong described his early exploration of the ontological and the phenomenal in his 1916 writing, “Chuanshanxue ziji” 船山學自記 (Personal note on Chuanshan's learning):

年十三歲, 登高而傷秋毫, 時喟然嘆曰: 此秋毫始為茂草, 春夏時, 吸收水土空氣 諸成分, 而油然滋榮者也。未幾, 零落為秋毫, 刹那刹那, 將秋毫且不可得, 求其原質, 亦 復無有。三界諸有為相, 皆可作如是觀。頓悟萬有皆幺。由是放蕩形骸, 妄駎淫 佚，久之覺其煩惱，更進求安心立命之道。因悟幻不自有，必依於真。 如無真者, 覺幻是誰? 泯此覺相, 幻復何有? 以有能覺, 幻相斯起。 此能覺者, 是名真我。時則以情器爲泡影, 索真宰於寂滅, 一念不生, 虛空粉碎, 以此爲至道之歸矣。既而猛然有省曰, 果幻相爲多事者, 云何依真起幻？既依真起幻, 云何斷幻求真? 幻如可斷者, 即不應起, 起已可斷者, 斷必復起。又捨幻有真者, 是真幻不相干, 云何求真? 種 種疑慮, 莫獲正解, 以是身心無主, 不得安穩。乃忽讀 《王船山遺書》, 得悟道器一元, 幽明一物。全道全器, 原一誠而無幻; 即幽即明, 本 一貫而何斷？......余基治船山學，頗好之，近讀餘杭章先生《建立宗教 論》, 聞三性三無性義, 益進討竺墳, 始知船山甚淺。134

At thirteen years of age, I ascended a height and was sad about the autumnal hay. At that time, I sighed: the autumnal hay was originally luxuriant grass. In spring and summer, it absorbed various elements like water, soil and air, and became that which is profuse and flourishing. Before long, it withered and fell, and then became autumnal hay. Moment after moment, even the autumnal hay will cease

134 Xiong, “Chuanshanxue ziji”, pp. 5-6. 
to exist. I look for its original material, but it too no longer exists. The various conditioned phenomena in the past, present and future can all be viewed like this. Suddenly I realised that all existing things are illusory. Thereby I started down a dissolute path, unrestrained and dissipated. After a period of time, I realised how troublesome [such a life] was and instead sought to find a way to give meaning to my life. I consequently realised that illusions could not appear on their own; they must depend on a reality [to exist]. If there is nothing real, then who is it that is aware of illusions? If the characteristic of this awareness is eliminated, then how can there be illusion? Because there is that which is aware, illusory characteristics arise. This entity that is aware is called "true self". At that time, I then took feelings and concrete things to be "bubbles and shadows", and sought for the "true ruler" within the state of stillness [of mind] and extinction [of sensation]. Not a single thought arose, and so the illusory world was shattered. I considered this a turn to "the supreme way". Soon afterwards, I suddenly had an awakening that if illusory characteristics are really unecessary, then why do illusions arise in dependence on what is real? Since illusions arise in dependence on what is real, then why seek reality by removing illusions? If illusions can be removed, then they should not arise. If they can be removed after having arisen, then they will inevitably arise again after having been removed. Moreover, if reality can be obtained after illusions have been abandoned, then reality and illusions indeed have nothing to do with each other. [So] why seek reality [through abandoning illusions]? None of my various doubts and concerns received a proper explanation. Therefore, my body and mind could not be steadied and calmed. Yet I suddenly read the Wang Chuanshan yishu 王船山遺書 (Posthumous writings of Wang Chuanshan),135 and came to realise that the "way"

135 Chuanshan 船山 is a designation of Wang Fuzhi. 
and concrete things have the same origin, and that the invisible and the visible are the same thing. The way is the entirety of concrete things, and originally there is only genuineness without any illusion; the invisible is the visible, and they are inherently interconnected as one, so how can they be severed? ... I previously studied Chuanshan's learning and was quite fond of it. Recently I read the "Jianli zongjiao lun" of Mr. Zhang [Taiyan], who is from Yuhang, and heard about the meanings of the "three natures" and the "three kinds of absence of nature".136 Then I further delved into Indian classics, and subsequently came to know that Chuanshan is very shallow.

The above describes Xiong's reflections on the phenomenal world and its Reality in his early period before 1920. In short, Xiong first realised that everything in the phenomenal world was illusory, and then further speculated that these illusions must rely on something real to appear. He named this real thing "true self" (zhenwo 真我) or “true ruler” (zhenzai 真宰), and then tried to seek it by getting rid of the phenomenal "illusions". Yet later he pondered on the relationship between that which is real and the illusions and had a sense that it is not logical to seek the former through eliminating the latter, although he was not able to figure out a reasonable explanation to support his conjecture at the time.

According to Xiong, it was Wang Fuzhi's philosophy that solved his problem and led to his realisation that the ontological and the phenomenal are non-dual. Wang held a view that the way (dao 道), or that which is above form (xing'ershangzhe 形而上者), and concrete things ( qi 器), or that which is below form (xing'erxiazhe 形而下者), are a unity. ${ }^{137}$ Also, Wang insisted that although the way and phenomenal images (xiang 象) have different names, they are actually

\footnotetext{
136 The "three natures" (san xing 三性; tri-svabhāva) and the "three kinds of absence of nature" (san wuxing 三無性) are two interrelated doctrines in Yogācāra philosophy, which will be explained in the following main text.

137 See, for example, Wang Fuzhi, Zhouyi waizhuan 周易外傳 (An extended interpretation of the Book of Change), in Chuanshan quanshu, vol. 1, p. 1029.
} 
one. ${ }^{138}$ It must be this kind of monistic ontology in Wang's works that influenced Xiong's own understanding of the ontological and the phenomenal. In particular, Wang believed that the way was not outside phenomenal images such that we cannot know the former while ignoring the latter. ${ }^{139}$ This would have theoretically supported Xiong's conjecture that it is not logical to seek "that which is real" through eliminating the "illusions".

The above quotation also shows that although Wang Fuzhi's philosophy played an important role in Xiong's early understanding of the relationship between the ontological and the phenomenal, it was Zhang Taiyan's discussions on the Yogācāra teachings of the "three natures" (san xing 三性; tri-svabhāva) and the “three kinds of absence of nature" (san wuxing 三無性) that led to Xiong's further research on Indian Buddhism and, as a result, a deeper contemplation of the ontological and the phenomenal.

The "three natures" is an important doctrine in Yogācāra Buddhism. The first nature is the nature of existence produced from attachment to imaginatively constructed discrimination (bianji suozhi xing 遍計所執性; parikalpita-svabhāva); the second nature is the nature of existence arising from causes and conditions $(y i$ ta qi xing 依他起性; paratantra-svabhāva); the third nature is the nature of existence being perfectly accomplished (yuan cheng shi xing 圓成實性; parinișpanna-svabhāva). The "three kinds of absence of nature" is a theory that corresponds to the "three natures". The first is the lack of nature in imaginary form (xiang wuxing 相無性); the second is the lack of nature in that which is produced by causation (sheng wuxing 生無性); the third is the lack of nature in ultimate truth (shengyi wuxing 勝義無性). Both the "three natures" and the "three kinds of absence of nature" aim to reveal that all dharmas in the phenomenal universe are empty and do not have self-nature and that their true nature (shixing 實性) is suchness. In this sense, Reality and the phenomenal world are not different,

\footnotetext{
138 Ibid., p. 1038.

139 Ibid.
} 
although they are also not the same (fei yi fei yi 非一非異). ${ }^{140}$

In his 1906 "Jianli zongjiao lun", Zhang Taiyan explained the phenomenal world on the basis of the doctrine of the three natures. According to him, these three natures apply to the whole phenomenal world. The first two natures, which are produced by consciousness, are false constructs. Thus, phenomena do not have selfnature but are only manifestations of consciousness. The third nature, which is also called suchness, is the Reality and the true nature of everything. For Zhang, the fact that phenomena do not have self-nature is equivalent to the fact that they have only suchness/“the nature being perfectly accomplished” as their true nature. However, although suchness, or "the nature being perfectly accomplished", is the true nature of phenomena, it is not the cause of phenomenological creation. It is the eighth or store consciousness (alaiye shi 阿賴耶識; àlayavijñāna) that acts as the ontological source and foundation for phenomena. ${ }^{141}$ In Zhang's opinion, this consciousness is real. ${ }^{142}$

Zhang's "Jianli zongjiao lun" would have provided Xiong with another way of thinking about the relationship between the ontological and the phenomenal. According to the passage quoted above, at that time, Xiong believed that Zhang's

\footnotetext{
140 See Yu Lingbo 于凌波, Weishi sanlun jin quan 唯識三論今詮 (A contemporary interpretation of the three Yogācāra treatises), Taibei: Dongda tushu gongsi, 2008, pp. 233-240.

141 In Yogācāra philosophy, consciousness is divided into eight types: the five sense consciousnesses (the visual, auditory, olfactory, gustatory and tactile); the mental or thinking consciousness (mano-vijñana); the self-centred consciousness (manas); and the store consciousness (ālaya-vijñanna). For a brief discussion of these eight types of consciousness, see John Makeham, "The Significance of Xiong Shili's Interpretation of Dignāga's Ālambana-parīkșā (Investigation of the Object)", Journal of Chinese Philosophy, vol. 40, no. supplement S1, December 2013, p. 210; Tao Jiang, Contexts and Dialogue: Yogācāra Buddhism and Modern Psychology on the Subliminal Mind, Honolulu: University of Hawaii Press, 2006, pp. 58-59. For a detailed introduction to these consciousnesses, see Tagawa Shun'ei, Living Yogācāra: An Introduction to Consciousnessonly Buddhism, translated with an introduction by Charles Muller, Boston: Wisdom Publications, 2009, pp. 11-18.

142 See Zhang Taiyan 章太炎, “Jianli zongjiao lun” 建立宗教論 (On founding a religion), in Zhang Taiyan quanji 章太炎全集 (The complete works of Zhang Taiyan), Shanghai: Shanghai renmin chubanshe, 1985, vol. 4, pp. 403-419. Also, see John Makeham's discussion on Zhang Taiyan's ontology in his "Zhang Taiyan, Yogācāra Buddhism, and Chinese Philosophy”, pp. 108-113.
} 
thought was more insightful compared to Wang Fuzhi's philosophy. Above all, both Wang's and Zhang's ontologies influenced Xiong's nascent understanding of the ontological and the phenomenal.

In addition, as we shall see later in this thesis, between the late 1920 s and the mid-1930s Xiong identified our mind with Reality. In fact, Xiong's reflections on the mind can be traced back to when he was sixteen or seventeen years old. As mentioned earlier in this thesis, at that time, he read the works of the Ming NeoConfucian Chen Baisha and was especially fond of Chen's "Qinshou shuo". According to Xiong, the following passage in particular in "Qinshou shuo" greatly influenced him:

\section{人具七尺之軀, 除了此心此理, 便無可貴, 渾是一包膿血裏一大塊骨 頭，飢能食，渴能飲，能著衣服，能行淫慾，貧賤而思富貴，富貴而 貪權勢, 忿而爭, 憂而悲, 窮則濫, 樂則淫, 凡百所爲, 一任血氣, 老死而後已，則命之曰禽獸可也。143}

The human has a body six feet tall. Apart from this mind and this principle, there is nothing else about it worth esteeming. It is simply a large piece of bone in a sack of purulent blood. It can eat when hungry, can drink when thirsty, can wear clothes, and can exercise lust. It longs for riches and honour when it is poor and lowly, and it has an insatiable desire for power and influence when it is rich and honoured. It disputes when angry, and it feels sad when depressed. It gets greedy when it is poor, and it gets wanton when it is at ease. All of its doings are determined by blood and vital stuff, and after death they are no more. So it can be called a beast.

Here Chen highlights the significance of the mind (xin 心) and principle (li 理). As related by Xiong, when he read this passage for the first time, he suddenly felt

143 Quoted in Xiong, “Chen Baisha xiansheng jinian”, p. 279. 
tremendously excited, as it inspired and enlightened him:

當時頓悟血氣之軀非我也, 只此心此理方是真我。血氣一團宛然成泪少 小之物, 而此心此理則周遍乎一切物之中, 無定在而無所不在, 是复 然絕待也。144

At that moment, I suddenly realised that the body of blood and vital stuff was not myself and that only this mind and this principle were my "true self". The lump of blood and vital stuff was clearly an insignificant thing, while this mind, this principle pervaded all things - it had no fixed place but was ubiquitous, and it was pre-eminent and absolute.

Here, for Xiong, the mind and the principle are the same thing, that is, the "true self", which is the only Reality in the world. As an important figure in the so-called NeoConfucian School of Mind, Chen Baisha emphasised recognising the "mind". According to the Ming ru xue'an 明儒學案 (The record of Ming scholars), Chen said that after a long period of quiet sitting (jingzuo 靜坐), he saw the mind itself (xin zhi ti 心之體) emerging dimly. ${ }^{145}$ Given Xiong's response, it is clear that Chen's words influenced his decision to focus on realising the "mind", an important perspective in his 1932 Xin weishi lun.

Although Xiong's establishment of his ti-yong metaphysics during the period between 1920 and 1937 was stimulated by his dissatisfaction with Yogācāra learning, it can be seen from the above that his exploration of Reality and Function began before 1920. Xiong's thinking on the phenomenal world and its ontological Reality and his understanding of the concept of "mind" in his early period laid a foundation for his later philosophical system and became a nodal point for his $t i$ yong metaphysics. Xiong's exploration of the issue of Reality and Function between 1920 and 1937 can be seen, to some extent, as a continuation and development of

\footnotetext{
144 Ibid., p. 280.

145 See Huang Zongxi 黃宗羲, “Baisha xue’an, shang” 白沙學案上 (The record of Baisha, A), Ming ru xue'an 明儒學案 (The record of Ming scholars), Beijing: Zhonghua shuju, 1985, vol. 1, p. 80.
} 
his pre-1920 thought.

\subsection{A Dispute Concerning Reality and Function in the Early Twentieth Century}

In fact, there was a dispute concerning Reality and Function in the early decades of the twentieth century. That dispute focused mainly on whether Reality is quiescent or active, a topic closely associated with the relationship between Reality and Function: only if Reality involves an aspect of activity can it be connected with the phenomenal world; if it is quiescent, then it would be difficult to explain why a quiescent Reality is able to be manifested as various phenomena.

The dispute about whether Reality is quiescent or active was reflected in the movement to retrieve "genuine" Buddhism and its related debates. The Buddhist layman Ouyang Jingwu and his students, notably Wang Enyang 王恩洋 (18971964) and Lü Cheng 呂澂 (1896-1989),146 believed that the Yogācāra tradition developed by such Indian Yogācāra masters as Asañga (Wuzhuo 無著; fourth century) and Vasubandhu (Shiqin 世親; fourth century), ${ }^{147}$ and promulgated in China mainly by Xuanzang and Kuiji 窺基 (632-682),148 was “genuine” Buddhism, whereas the metaphysics in the Dasheng qi xin lun and its related texts was a "false", “fake" or "pseudo" Buddhism (xiangsi foxue 相似佛學). Ouyang and his students devoted themselves to recovering "genuine" Buddhism and discrediting this "mistaken" Buddhism. ${ }^{149}$ Accordingly, the retrieval of "genuine" Buddhism basically indicates an antagonism between Yogācāra Buddhism and certain schools of Buddhism that developed in China.

\footnotetext{
146 Wang Enyang and Lü Cheng were famous Buddhist scholars in the twentieth century and Xiong Shili's colleagues in the China Institute of Inner learning.

147 Asanga was a founder of the Indian Yogācāra school; Vasubandhu was Asañga's brother who developed Asañga's thought.

148 Kuiji was a prominent student of Xuanzang.

149 See Dan Lusthaus, "Lü Cheng, Epistemology, and Genuine Buddhism", in Transforming Consciousness, ed. John Makeham, pp. 319-322; Chen-kuo Lin, "The Uncompromising Quest for Genuine Buddhism: Lü Cheng's Critique of Original Enlightenment”, ibid., pp. 346, 357-360.
} 
The main ground on which Ouyang and his students attacked the Dasheng qi xin lun lies precisely in the contrasting views between Yogācāra philosophy and the thought in the Dasheng qi xin lun on whether Reality is quiescent or active. As Wingtsit Chan elaborated, Yogācāra holds a view that suchness (Reality) remains always in a state of quiescence and is in no way connected with the specific characteristics of dharmas - phenomenal activities are manifestations of consciousness, and their generation has nothing to do with suchness. On the other hand, the Dasheng qi xin Iun maintains that suchness is both tranquil and aroused to action and that it is intimately connected with the world of multiplicity and specific characteristics. By subsuming suchness and phenomenal activities within the One Mind, suchness and phenomenal activities involve one another and cannot be separated from each other. The perspective in the Dasheng qi xin lun that suchness is both tranquil and aroused to action is the crux of what Ouyang and his students rejected. ${ }^{150}$

In 1922, Ouyang gave a series of lectures titled “Weishi jueze tan” 唯識抉擇 談 (Decisive talks on Yogācāra) in the China Institute of Inner Learning. According to the transcript of this series of lectures,151 taking aim at the claim that "suchness is perfumed by the myriad conditioned dharmas" (真如受熏緣起萬法) in the Dasheng qi xin lun,152 Ouyang expressed his view that suchness is quiescent rather than active:

就無漏言, “真如是所緣, 正智是能緣。能是其用, 所是其體, 詮法
宗用, 故主正智。” 用從熏習而起, “熏習能生, 無漏亦然。真如體

\footnotetext{
150 See Wing-tsit Chan, Religious Trends in Modern China, New York: Columbia University Press, 1953, pp. 106-108, 112-117.

151 There are two versions of Ouyang's speeches. One is the original manuscript provided by Ouyang himself; the other is the transcript of the speeches recorded by Ouyang's student Nie Ougeng 聶耦 耕 (?-?) and edited by Lü Cheng. The former is concise, and the latter records Ouyang's thought in more detail.

152 See Ouyang Jingwu 歐陽竟無, “Ouyang Jingwu xiansheng yanjiang” 歐陽竟無先生演講 (Mr. Ouyang Jingwu's speeches), recorded by Nie Ougeng and edited by Lü Cheng, in Weishi jueze tan 唯 識抉擇談 (Decisive talks on Yogācāra), Nanjing: Zhina neixue yuan, 1922, p. 21.
} 
義，不可說種，能熏、所熏、都無其事。” 153

In regard to the undefiled (anāsrava),154 "suchness is the ālambana,155 and true insight (samyag-jñana) is the perceiver. ${ }^{156}$ The subject [true insight] is the Function [of suchness], and the object [suchness] is the Reality [of true insight]. In explaining [these five] dharmas, ${ }^{157}$ I attach importance to Function, and so emphasis is placed on true insight." Function arises from habituation (vāsanā). "Habituation is able to generate, and so does the undefiled [i.e. true insight]. Suchness means Reality, and it cannot be taken as seeds (bïja). ${ }^{158}$ Both the perfumer and

153 Ibid., p. 20. The words in quotation marks are those in Ouyang's original manuscript.

154 The "undefiled" (wulou 無漏; anāsrava) refers to that which is not tainted by nescient goalorientations. See the Digital Dictionary of Buddhism, ed. A. Charles Muller, under the entry “無漏”. Here the "undefiled" in Ouyang's statement refers to the "true insight" of the following. It is short for wulou xin fa 無漏心法, the dharma that is the undefiled mind.

155 Ālambana (suoyuan 所緣) refers to a cognitive object that is taken to be the cause of consciousness. See John Makeham, "Xiong Shili on Why Reality Cannot be Sought Independent of Phenomena", Sophia, vol. 56, issue 3, September 2017, pp. 505-506. For Ouyang, the ālambana is "having" - mentally grasping - a cognitive object (jing 境; vișaya) that appears as the image part in consciousness. See John Makeham, "Interpretations of Ālambana-parīkșā in the Early Days of the Peking University Philosophy Department", forthcoming.

156 "True insight" (zhengzhi 正智; samyag-jñāna), known variously as "fundamental nondiscriminating cognition" (genben wu fenbie zhi 根本無分別智), “non-discriminating cognition" (wu fenbie zhi 無分別智; nirvikalpa-jñanna), "essential non-discriminating cognition” (zhengti wu fenbie zhi 正體無分別智), and “essential cognition” (zhengti zhi 正體智), refers to the realisation of suchness when there is no attachment to self or attachment to dharmas.

157 This passage is taken from Ouyang's discussion of five particular dharmas: phenomenal appearances (xiang 相; nimitta), names (ming 名; nāma), discrimination (fenbie 分別; saṃkalpa), true insight, and suchness.

158 According to John Powers, in Yogācāra Buddhism, "seeds" (zhong 種 or zhongzi 種子; bīja) are the latent residua of a person's actions, and they compose the store consciousness (ālayavijñanna), a substratum underlying all aspects of mind. As he explains, "every volitional action deposits a predisposition within one's mental continuum, which represents a propensity to perpetuate that sort of action and also guarantees the karmic repercussions of one's moral choices. As the metaphor of seeds implies, they lie dormant until the proper conditions for their manifestation are present and then give rise to mental states that resemble the original impulses that led to their creation. A popular metaphor associated with this process is often referred to as "perfuming" in contemporary discussions of Yogācāra. ... In this context, perfuming refers to the idea that predispositions or habituations condition the seeds that constitute the mental stream, similar to the way in which 
that which is perfumed have nothing to do with it."

In Ouyang's view, as Lin Zhenguo 林鎮國 explains, although suchness can be regarded as Reality from the ontological perspective, it can only be a cognitive object - that is, the condition of cognition - from an epistemological perspective. Indeed, what acts is actually true insight, that which perceives suchness. ${ }^{159}$ True insight, as the corresponding Function of suchness, is able to generate or be generated, but suchness as its Reality cannot have this kind of activity. This clearly demonstrates Ouyang's perspective that suchness, as Reality, is quiescent rather than active, and that it is an unconditioned dharma (wuwei fa 無爲法; asamskrtadharma) independent of the phenomenal world. ${ }^{160}$ Through this view Ouyang refuted the idea that suchness can be perfumed by the myriad conditioned dharmas.

Following his above statement, in "Weishi jueze tan" Ouyang further expressed his disagreement with the view that Reality is active, by criticising the Dasheng qi xin lun. According to Ouyang, the early Indian Buddhist thinker Aśvaghoșa (Maming 馬鳴, ?-?), the putative author of the Dasheng qi xin lun, was influenced by the Vibhajyavādin (fenbielunzhe 分別論者) school of Hīnayāna. For Ouyang, the doctrine of the Vibhajyavādin is "simple, shallow, fragmented and disorganised" (cuqian zhili 粗淺支離). Since Aśvaghoṣa was influenced by this Hīnayāna school, as well as the fact that the Dasheng qi xin lun was supposed to have been composed at the time when Aśvaghoșa was experiencing the transition from Hīnayāna to Mahāyāna, the Dasheng qi xin lun naturally retained the "mistake"

perfume pervades a cloth." See John Powers, "Yogācāra: Indian Buddhist Origins", in Transforming Consciousness, ed. John Makeham, p. 46.

159 Lin Zhenguo 林鎮國, “Qi xin lun yu xiandai Dongya zhutixing zhexue: yi Neixueyuan yu xin rujia de zhenglun wei zhongxin de kaocha" 《起信論》與現代東亞主體性哲學一一以内學院與新儒家的 爭論為中心的考察 (The Treatise on Giving Rise to Faith and the philosophy of subjectivity in modern East Asia: an investigation centred on the debates between the Institute of Inner Learning and new Confucians), available at: https://www.academia.edu/34117398/_起信論_與現代東亞主 體性哲學_20170803.pdf, p. 7, accessed August 5, 2018.

160 "Unconditioned dharma" refers to that which is not subject to arising, changing and ceasing or to the laws of cause and effect. See the Digital Dictionary of Buddhism, ed. A. Charles Muller, under the entry “無爲法”. 
made by the Vibhajyavādin. 161 On the "mistake" that the Vibhajyavādin had committed and that the Dasheng qi xin lun followed, Ouyang stated:

“分別論者無法爾種, 心性本淨, 離煩惱時即體清淨爲無漏因, 如乳 有 [變] ${ }^{162}$ 酪, 乳有酪性。是則以體爲用, 體形既淆, 用性亦失, (體爲其 因, 因是生義, 豈是不生? 自不能立, 須待他體以爲其因, 故用性失。) 過即無邊。” 163

"For the Vibhajyavādin, there is no seed that exists naturally. The nature of mind is inherently pure. When [the mind] is detached from afflictions, then its Reality is pure and is undefiled cause. This is like the transformation of milk into curd, [on the ground that] milk possesses the nature of curd. In this way, Reality is taken as Function. The appearance of Reality is confused [with that of Function], and the characteristic of Function is also lost. (Reality is the cause [of the undefiled]. "Cause" means "generation", so how can [Reality] not generate? [The undefiled] cannot exist itself, and it must depend on another reality as its cause. Therefore, the characteristic of Function is lost.) Then the fault is endless."

This statement demonstrates Ouyang's disagreement with the idea that the mind is inherently pure, and that this pure nature of mind is indeed Reality, which acts as the cause for the undefiled. For Ouyang, if Reality is the cause of the undefiled, then this means that Reality is able to generate, which would cause Reality to be confused with Function, and so runs counter to the characteristic of Reality, which

161 See Ouyang, "Ouyang Jingwu xiansheng yanjiang”, recorded by Nie Ougeng and edited by Lü Cheng, pp. 24-25.

162 Nie Ougeng and Lü Cheng's transcript records this sentence as “如乳有酪”. Yet Ouyang’s original manuscript says “如乳變酪”. See Ouyang’s original words in his “Weishi jueze tan” 唯識抉擇談 (Decisive talks on Yogācāra), in Ouyang Jian xuanji 歐陽漸選集 (Selected works of Ouyang Jingwu), Xiandai foxue daxi 現代佛學大系 (Modern Buddhist studies series), vol. 51, Xindian: Mile chubanshe, 1984, p. 284. According to the context of this sentence, Ouyang's manuscript seems to make more sense.

163 Ouyang, "Ouyang Jingwu xiansheng yanjiang”, recorded by Nie Ougeng and edited by Lü Cheng, pp. 24-25. 
cannot have any activity but only remain in a state of quiescence. Indeed, as Eyal Aviv points out, the view that suchness (Reality) as an unconditioned dharma can serve as the basis for, or give rise to, conditioned dharmas (youwei fa 有爲法; samskrta-dharma) expressed in the Dasheng qi xin lun is precisely what Ouyang objected to at the time. ${ }^{164}$ Above all, Ouyang's objection to the Dasheng qi xin lun is still related to his perspective that Reality is quiescent rather than active, and so it is isolated from phenomenal activities.

Ouyang's critique of the Dasheng qi xin lun triggered a series of debates. Taixu 太虛 (1890-1947), a prominent Chinese Buddhist scholar and monastic reformer in the twentieth century, rejected Ouyang's view and instead held that there is nothing wrong with Reality being active. Taking aim at Ouyang's "Weishi jueze tan", Taixu wrote “Fofa zong jueze tan” 佛法總抉擇談 (A discussion on the overall choices of the Buddha's teachings) in 1922. In this article, Taixu expressed his view that suchness is active and creative:

一切法共通之本體, 則真如也, 即所謂大乘體。真如體上之不可離不 可滅相一一真如自體相, 如來藏也。換言之, 即無漏種子, 亦即本覺, 亦即大乘相大。所起現行即真如用, 即能生世出世間善因果之大乘用。 其可㝴可離相, 則無明也- - 一切染法皆不覺相。換言之, 即有漏種 子, 即違大乘體之逆相; 所起現行則三細六鹿等是也。165

The common Reality shared by all dharmas is indeed suchness, namely, the so-called reality of Mahāyāna. The inseparable and unceasing characteristic of suchness, that is, the characteristic of suchness itself,

\footnotetext{
164 Eyal Aviv, "Ouyang Jingwu: From Yogācāra Scholasticism to Soteriology", in Transforming Consciousness, ed. John Makeham, pp. 308-310. "Conditioned dharmas" is a basic concept in Buddhism. Generally speaking, it refers to the things in the phenomenal world which are subject to cause and effect and which arise, change and cease. See the Digital Dictionary of Buddhism, ed. A. Charles Muller, under the entry “有爲法”.

165 Taixu 太虛, “Fofa zong jueze tan”佛法總抉擇談 (A discussion on the overall choices of the Buddha's teachings), in Taixu dashi quanshu 太虛大師全書 (The complete works of Master Taixu), Taibei: Taixu dashi quanshu yingyin weiyuanhui, 1998, vol. 9, p. 1377.
} 
is the store of the tathägata. To put it another way, it is the undefiled seeds, and it is also the inherent enlightenment or the greatness of the characteristics of Mahāyāna. The manifest activities generated by it are the function of suchness, namely, the function of Mahāyāna as the generator of the causes and effects of good deeds, both mundane and supramundane. Its [Suchness'] severable and separable characteristic is indeed ignorance, 166 that is, the characteristic that all defiled dharmas are unenlightened. To put it another way, it is the defiled seeds and the counter characteristic that opposes the reality of Mahāyāna. The manifest activities generated by it are such things like the three subtle and the six coarse characteristics. ${ }^{167}$

For Taixu, the inseparable and unceasing characteristic of suchness is the undefiled seeds, which generate the function of suchness that produces the causes and effects of good deeds. The severable and separable characteristic of suchness is the defiled seeds, which generate the unenlightened characteristics. The equivalence of suchness and seeds as well as the ability of suchness to generate manifest activities in this passage clearly demonstrates a perspective that Reality is active rather than quiescent. In addition, this passage is obviously an interpretation of certain terms and ideas in the Dasheng qi xin lun. Through this interpretation, Taixu actually defended the Dasheng qi xin lun whilst affirming the idea that suchness is active

\footnotetext{
166 Rather than a lack of factual knowledge, “ignorance” (wuming 無明) is a basic error in mode of perception that underlies all of the sufferings of unenlightened people and that prevents people from seeing things as they really are. See the Digital Dictionary of Buddhism, ed. A. Charles Muller, under the entry “無明”.

167 The "three subtle characteristics" (san xi 三細) and the "six coarse characteristics" (liu cu 六鷹) are two kinds of ignorance presented in the Dasheng qi xin lun. The former refers to "the characteristic of the karmic action of ignorance" (wuming ye xiang 無明業相), "the characteristic of the subjective perceiver" (nengjian xiang 能見相), and "the characteristic of perceptual fields" (jingjie xiang 境界相). The latter refers to "the characteristic of cognition" (zhi xiang 智相), “the characteristic of continuous flow" (xiangxu xiang 相續相), “the characteristic of attachment” (zhiqu xiang 執取相), “the characteristic of devising names” (ji mingzi xiang 計名字相), “the characteristic of producing karma" (qi ye xiang 起業相), and “the characteristic of suffering through the bondage of karmic action" (ye xi ku xiang 業繫苦相). See Gao, Dasheng qi xin lun jiaoshi, p. 46, 48.
} 
rather than quiescent.

After Taixu refuted Ouyang's view in his "Fofa zong jueze tan", Ouyang's student Wang Enyang wrote an essay titled “Dasheng qi xin lun liaojian” 大乘起信 論料簡 (An explanation of the Treatise on Giving Rise to Faith in the Great Vehicle) in 1923 to support his teacher. In that essay, Wang expounded the concept of suchness and further elaborated Ouyang's perspective that suchness is quiescent rather than active and that it is isolated from phenomenal activities. According to Wang, suchness, as an unconditioned dharma, is detached from such "conditioned characteristics" (youwei xiang 有爲相) as arising (sheng 生), abiding (zhu 住), changing (yi 異) and ceasing (mie 滅). It is neither generated nor able to generate. Therefore, it is not generated by the myriad dharmas, and it is also not able to generate the myriad dharmas. ${ }^{168}$ Based on this clarification of the characteristic of suchness, Wang then criticised the idea in the Dasheng qi xin lun that is contradictory to his view:

此論中所云真如, 以能生故, 性是有爲, 即非無爲。而佛法真如則是 無爲。爲與無爲, 亦各不同。既有如是之不同, 是非不能並立, 真妄 豈得俱存? 吾人既不能謂《般若》《瑜伽》等所言者非佛法, 更不能 謂彼所詮真如爲背法性, 則《起信論》所立之真如爲背法性, 其理決 定。是爲此論第一大失。169

Since suchness as discussed in this treatise [the Dasheng qi xin lun] is able to generate, its nature is conditioned rather than unconditioned. Yet suchness in the Buddha's teachings is unconditioned. Conditioned and unconditioned are not the same. Since there is this difference, and right and wrong cannot stand simultaneously, then how can the true and the false both exist? We cannot say that what is said in such works

\footnotetext{
168 Wang Enyang 王恩洋, “Dasheng qi xin lun liaojian” 大乘起信論料簡 (An explanation of the Treatise on Giving Rise to Faith in the Great Vehicle), in Wang Enyang xuanji 王恩洋選集 (Selected writings of Wang Enyang), Xiandai foxue daxi, vol. 51, pp. 564-565.

169 Ibid., 571.
} 
as Bore 般若 and Yuqie 瑜伽 are not the Buddha's teachings, 170 and we also cannot say that their interpretations of suchness violate the dharma-nature. Therefore, suchness established by the [Dasheng] qi xin lun violates the dharma-nature. The reasoning is conclusive. This is the first great error of this treatise.

According to this statement, Wang believed that the Dasheng qi xin lun presented suchness as a conditioned dharma that is able to generate. However, this characteristic of suchness is contrary to that presented by those Buddhist works that have generally been accepted as authoritative. Given this reason, Wang considered the presentation of suchness in the Dasheng qi xin lun to be false.

This sample of views on whether Reality is quiescent or active illustrates the debates concerning this issue in the early twentieth century. In fact, the dispute on whether Reality is quiescent or active was not a brand-new issue in the early twentieth century but, as I explain below, is closely related to the debates concerning whether "buddha-nature" (foxing 佛性) is acquired or is an inherent nature possessed by all sentient beings, an old issue in Chinese Buddhist history. According to John Makeham, these debates had already begun to be disputed in the sixth century between the two Dilun schools, the two competing versions of Yogācāra. ${ }^{171}$ The distinction between Yogācāra Buddhism and the Dasheng qi xin lun on whether Reality is quiescent or active caused the epistemologies of these two philosophical systems to be different as well. In Yogācāra Buddhism, since suchness is quiescent such that it is independent of phenomenal activities, we are not able to

\footnotetext{
170 Bore 般若 and Yuqie 瑜伽 refer probably to the Prajñāpāramitā Sūtra (Bore boluomi duo jing 般若波羅蜜多經; Sutra on the perfection of wisdom) and the Yogācārabhūmi-śāstra (Yuqie shidi lun 瑜伽師地論; Discourse on the stages of concentration practice), two authoritative works in Buddhism.

171 See Makeham, "Introduction”, in Transforming Consciousness, ed. John Makeham, p. 6. Also, Liao Minghuo 廖明活 involves many discussions on the issue of whether "buddha-nature" is acquired or is an inherent nature in Chinese Buddhist history in his Zhongguo foxing sixiang de xingcheng he kaizhan 中國佛性思想的形成和開展 (The formation and development of thought on buddhanature in China), Taibei: Wenjin chubanshe, 2008.
} 
recognise suchness immediately but must achieve it through certain practices, ${ }^{172}$ since in Yogācāra philosophy our mind is related to the phenomenal world but not connected directly to suchness. On the other hand, the Dasheng qi xin lun argues that suchness is active by presenting it as one aspect of sentient beings' mind, which indicates that the mind is inherently enlightened. Thus, we can recognise suchness merely by returning to our mind. The question of whether the mind of sentient beings is inherently enlightened is exactly the issue of whether sentient beings inherently possess the buddha-nature.

The Dasheng qi xin lun's view that the mind is inherenetly enlightened was also rejected by the adovates of the "genuine Buddhism" movement. As John Jorgensen relates, Ouyang Jingwu attacked the Dasheng qi xin lun on the grounds that it posits the inherent buddha-nature and hence is merely faith-based and not true Indian Buddhism. ${ }^{173}$ On this point, Lü Cheng held a similar view. ${ }^{174}$ Also, as Chen-Kuo Lin (Lin Zhenguo 林鎮國) points out, for Lü Cheng, "false Buddhism" refers precisely to those Sinitic forms of Buddhist teachings stemming from the doctrine of inherent enlightenment (benjue 本覺) that appeared in the Dasheng qi xin lun for the first time. ${ }^{175}$

When Ouyang Jingwu, Wang Enyang, and Taixu presented their views in 1922 and 1923, Xiong Shili had just finished his studies at the China Institute of Inner Learning and started teaching Yogācāra philosophy in Peking University. The movement to retrieve "genuine" Buddhism advocated by his teacher and colleagues in the China Institute of Inner Learning, as well as its related debates, must have affected him. Xiong's later meditation on whether Realty is quiescent or active and

\footnotetext{
172 See the practices in Ronald Epstein, "The Transformation of Consciousness into Wisdom in the Chinese Consciousness-only School According to the Cheng Wei-shi Lun", available at: http://online.sfsu.edu/rone/Buddhism/Yogacara/TRANSFORMATION\%200F\%20CONSCIOUSNES S.htm, accessed August 5, 2018.

173 John Jorgensen, “Indra's Network: Zhang Taiyan's Sino-Japanese Personal Networks and the Rise of Yogācāra”, in Transforming Consciousness, ed. John Makeham, p. 74.

174 See Lusthaus, “Lü Cheng, Epistemology, and Genuine Buddhism”, p. 322.

175 Chen-kuo Lin, “The Uncompromising Quest for Genuine Buddhism”, p. 357.
} 
identification of our mind with Reality, which indeed means that our mind is inherently enlightened, were probably his response to those debates.

\section{Concluding Remarks}

From what has been demonstrated in this chapter, we can see that the concepts of Reality and Function had undergone a long process of formation and development in the course of the history of Chinese philosophy before Xiong turned his attention to them. During this process, the non-duality of Reality and Function had become a mainstream idea. This idea is based on the fact that, as a conceptual polarity, Reality and Function are closely related: Reality is the Reality of Function, and Function is the Function of Reality. By Xiong's time, there had already been many Chinese thinkers, in particular those of Buddhism and Neo-Confucianism, who contributed to the understanding of Reality and Function and who interpreted the non-duality of them in their own ways. Thus, it is natural that Xiong drew upon traditional accounts of Reality and Function for his own understanding of these concepts and interpretation of their non-dual relationship when he developed his ti-yong metaphysics between 1920 and 1937. Indeed, it can be seen from the second section in this chapter that Xiong already expressed his view of the phenomenal world and its Reality before 1920 by drawing on the ideas of Wang Fuzhi, Zhang Taiyan, and Chen Baisha.

We can also see from this chapter that the concepts of Reality and Function are quite relevant to the "genuine Buddhism" movement and its related debates. Since Xiong had already begun to ponder the ontological and the phenomenal in his early period, and also since he already became a student of Ouyang Jingwu - the initiator of the "genuine Buddhism" movement - when the movement and its related debates were current in the early twentieth century, he must have paid close attention to the movement and debates and been inspired by them. This inspiration is reflected in the transformation of Xiong's views on Reality and Function between 1920 and 1937 and will be discussed later in this thesis. 


\section{Chapter Two}

\section{Xiong's Two-level Ti-yong \\ System between 1920 and 1923}

This chapter examines Xiong Shili's understanding of Reality and Function in the early 1920s. Although Xiong had yet to establish his systematic ti-yong philosophy by this stage, his scattered views on Reality and Function can still be found in his 1923 Weishixue gailun, which reflects his philosophical thought during this time. This chapter deals principally with Xiong's ideas in this work.

Although the Weishixue gailun was published in 1923,176 Xiong claimed that he began to compose it as early as 1921,177 while he was studying Yogācāra Buddhism at the China Institute of Inner Learning. It is natural and understandable that this work on Yogācāra is intertwined with what he was learning at the Institute. At a later time, Xiong revealed what he learnt there and what this work is about:

余初吒佛學即專攻唯識論, 追尋玄牀、窺基宣揚之業, 從護法諸師以 上索無著、世親, 悉其淵源、通其脈絡、綜其體系、控其綱要, 遂成 《唯識學概論》一書, 壬戌講授北庠北京大學。即此書節本。178

When I first inquired into Buddhist learning, I specialised in Yogācāra theories. I pursued what Xuanzang and Kuiji propagated by tracing

\footnotetext{
176 This work is generally considered to have been published in 1923. Yet it should be noted that the contemporary Confucian philosopher Cai Renhou 蔡仁厚 records its publication year as 1922. See Cai, Xiong Shili xiansheng xuexing nianbiao, p. 18. However, Cai describes the exact time of publication as "the twelfth month of the lunar year in the winter" (dongla 冬臘), which was actually from January $17^{\text {th }}$ to February $15^{\text {th }}$ in 1923 , according to the solar calendar.

177 Xiong, Xin weishi lun (wenyanwen ben, 1932), p. 9.

178 Xiong, Xin weishi lun (shanding ben, 1953) 新唯識論 (刪定本, 一九五三年) (New treatise on the uniqueness of consciousness [expurgated and finalised version, published in 1953]), in Xiong Shili quanji, vol. 6, p. 5.
} 
various masters such as Dharmapāla (Hufa 護法; sixth century) ${ }^{179}$ back to Asanga and Vasubandhu - knowing clearly their sources, comprehending thoroughly the threads of their thought, summing up their systems, and making notes of their outlines. Based on this, I composed the manuscript titled Weishixue gailun 唯識學概論 (A general account of Yogācāra learning). [The teaching material on which I] lectured in Beixiang Peking University in 1922 is precisely the abridged version of this manuscript.

Undoubtedly, Xiong's “first inquiry into Buddhist learning” refers to his experience at the China Institute of Inner Learning. As described in the above statement, his study at that time centred on the "Asanga-Vasubandhu-Dharmapāla-XuanzangKuiji lineage" of the Yogācāra school. ${ }^{180}$ Based on his research, Xiong drafted a manuscript entitled Weishixue gailun, the abridged version of which - namely, Xiong's teaching material on which he lectured at Peking University in 1922 - is precisely what he published in 1923 under the same title.181

Although Xiong's 1923 Weishixue gailun is a monograph that concentrates on explicating Yogācāra philosophy (with a focus on the Asañga-VasubandhuDharmapāla-Xuanzang-Kuiji lineage), his opinions on Reality and Function in this work emerge precisely from his explanations of certain Yogācāra theories. For this

\footnotetext{
179 Dharmapāla was an influential figure in the Indian Yogācāra school. He developed Vasubandhu's thought by commenting on his works.

180 Xiong divided the Yogācāra learning in China into two traditions: the "old" (guxue 古學) and the "new" (jinxue 今學). As John Makeham notes, Xiong identified Paramārtha as a representative figure in the "old" tradition of Yogācāra as transmitted in China in contrast to the "new" tradition which he associated with Xuanzang and Kuiji but which has roots in the teachings of Dharmapāla and Vasubandhu. See Makeham, "The Significance of Xiong Shili's Interpretation of Dignāga's Ālambanaparikssā (Investigation of the Object)", p. 225, note 54. As for Xiong's own expression of this differentiation of the two traditions in his 1923 work, see Xiong, Weishixue gailun (1923) 唯識學概 論 (一九二三年) (A general account of Yogācāra learning [published in 1923]), in Xiong Shili quanji, vol. 1, pp. 51-52.

181 For the relationship between Xiong's teaching material for his lectures at Peking University in 1922 and his 1923 publication of Weishixue gailun, see, for example, Cai, Xiong Shili xiansheng xuexing nianbiao, p. 18.
} 
reason, this chapter pays considerable attention to how Xiong interpreted those Yogācāra theories.

In his 1923 work, Xiong on the whole provided a faithful interpretation of Yogācāra learning, but he still offered independent judgements about Yogācāra theories, infused with his own opinions. He did this primarily through three approaches: his decision as to which Yogācāra theories should be included in (or excluded from) this work; ${ }^{182}$ his choice between the opinions of different Yogācārins in explaining an individual theory; ${ }^{183}$ and his integration of ideas from other philosophical schools with Yogācāra theories. These approaches play an important role in the expression of Xiong's views on Reality and Function and, thus, are examined in this chapter.

It is evident that, although Xiong also consulted other sources while accounting for Yogācāra theories, Kuiji's Cheng weishi lun shuji 成唯識論述記 (Commentary on the Treatise Demonstrating Nothing but Consciousness) was the most important and authoritative reference for him. ${ }^{184}$ This text is a significant

182 Wang Shouchang 王守常 also mentions that Xiong made his own choice concerning what content should be included in his 1923 Weishixue gailun. As Wang points out, this choice reflects Xiong's understanding of Yogācāra learning. Wang Shouchang 王守常, “Ershi shiji ru fo zhi zheng: Xiong Shili yu Liu Dingquan de zhenglun” 二十世紀儒佛之爭一一熊十力與劉定權的爭論 (The battles between Confucianism and Buddhism in the twentieth century: the debate between Xiong Shili and Liu Dingquan), in Xiong Shili quanji, supplementary volume A, p. 567.

183 John Makeham has an argument that is relevant to this point. According to him, in the 1923 Weishixue gailun Xiong adopted Xuanzang's interpretation of Ālambana-parīkșā (Investigation of the object) by the early Indian Yogācāra master Dignāga (Chenna 陳那, ca. 480-540), through which Xiong showed his disagreement with some of Dignāga's views. As Makeham argues, Xiong's 1923 work therefore already manifests the first indications of his critical attitude to Yogācāra. See Makeham, "The Significance of Xiong Shili's Interpretation of Dignāga's Ālambana-parīkṣā (Investigation of the Object)", pp. 205-225.

184 Xiong probably attached much importance to Cheng weishi lun shuji because of the impact of this text in the early twentieth century. In the 1880s, the Chinese Buddhist layman Yang Wenhui 楊文會 (1837-1911) received from the Japanese Buddhist scholar Nanjō Bun'yū 南條文雄 (1849-1927) a number of Buddhist texts that had been lost in China. Among them, the Cheng weishi lun shuji was published by Yang Wenhui in 1901, and it aroused interest in Yogācāra Buddhism. See Chan, Religious Trends in Modern China, p. 110; Aviv, "Ouyang Jingwu: From Yogācāra Scholasticism to Soteriology", p. 290. 
work for providing crucial glosses on Xuanzang's Cheng weishi lun 成唯識論 (Treatise demonstrating nothing but consciousness), ${ }^{185}$ which is essentially a composite of commentaries on Vasubandhu's Trimsśikā (Weishi sanshi lun song 唯 識三十論頌; Thirty verses). Kuiji claimed that Dharmapāla's opinion was the most authoritative among those commentaries. ${ }^{186}$ Accordingly, I will cite selected passages from these texts or refer to other scholars' explanations of these texts to clarify some of Xiong's statements. By comparing Xiong's views with original textual meanings, I will indicate where Xiong might have deviated from the Dharmapāla-Xuanzang tradition (or Yogācāra as a whole) and the tendencies his views have, since it is precisely these places and tendencies that mirror his own perspectives.

Above all, through the aforementioned approaches to revealing Xiong's views of Reality and Function in his 1923 work, this chapter attempts to answer: What did Xiong, in the early 1920s, conceive as Reality? What did he conceive as Function? How did he characterise them? How did he designate the relationship between them? And, crucially, did he consider Reality and Function to be non-dual or two distinct realms? The clarification of these issues should provide a clear understanding of how Xiong understood Reality and Function at this time.

\footnotetext{
185 In fact, according to Taixu, Xiong studied the Cheng weishi lun with Ouyang in the China Institute of Inner Learning. See Taixu, “Lüe ping Xin weishi lun” 略評新唯識論 (A brief review of New Treatise on the Uniqueness of Consciousness), in Xiong Shili quanji, supplementary volume A, p. 32. In addition, Shimada Kenji also noted that Xiong's account of Yogācāra learning in the early 1920s was based on Xuanzang's Cheng weishi lun. See Shimada Kenji, Xiong Shili yu xin rujia zhexue 熊十力與 新儒家哲學 (Xiong Shili and new Confucian philosophy), trans. Xu Shuisheng 徐水生, Taibei: Mingwen shuju, 1992, p. 19.

186 See Makeham, "Introduction", in Transforming Consciousness, ed. John Makeham, p. 8. Yet Makeham notes that some scholars, like Hidenori Sakuma and Dan Lusthaus, argue that it is often the interpretations of the seventh-century Yogācāra master Sthiramati (Anhui 安慧) that occupy the authoritative position. Ibid. For a detailed discussion on the transmission of the Cheng weishi lun by Kuiji as well as the position of Dharmapāla in relation to this work, see Dan Lusthaus, Buddhist Phenomenology: A Philosophical Investigation of Yogācāra Buddhism and the Ch'eng Wei-shih lun, London: RoutledgeCurzon, 2002, pp. 382-425.
} 
Overall, Xiong presented a two-level ti-yong system in his 1923 work:

不生滅是體, 生滅是用。用中復分體用: 功能是用之體, 現行是用之 用。187

That which neither arises nor ceases is Reality, and that which arises and ceases is Function. Within Function there is a further division into a Reality and a Function: productive power is the Reality within Function, and manifest activity is the Function within Function.

As we shall see, "that which neither arises nor ceases" and "that which arises and ceases" refer to the Yogācāra concept of suchness and consciousness (shi 識; vijñana) (or the dharmas/phenomena produced by consciousness) respectively. Indeed, according to Xiong, suchness and consciousness constitute the first level of the ti-yong system, just as productive power (gongneng 功能; śakti) and manifest activity (xianxing 現行; adhyācarati), another pair of Yogācāra concepts, constitute the second level. Schematically this two-level ti-yong system can be represented as follows:

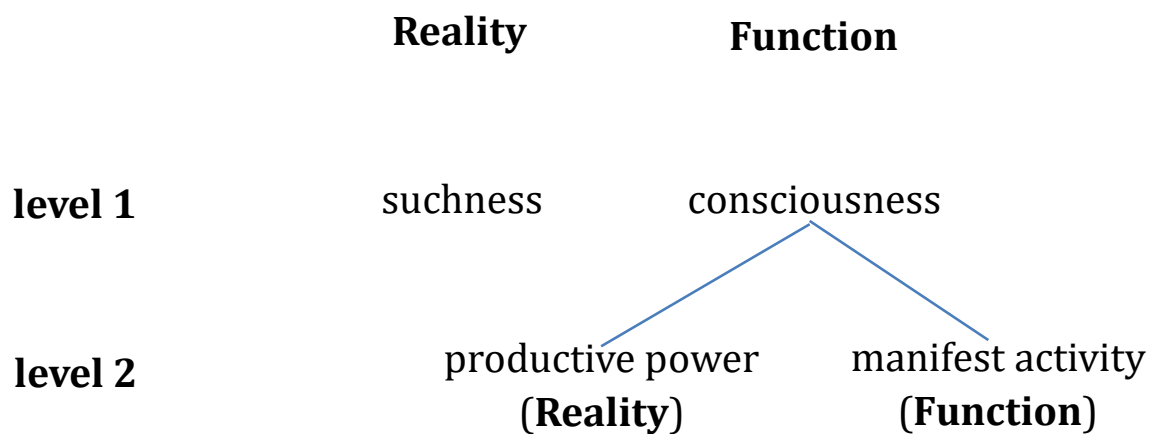

To clarify and render intelligible Xiong's understanding of Reality and Function in his 1923 work, this chapter, based on the two levels of his ti-yong system, is divided into three main sections. The first two (2.1 and 2.2) discuss Xiong's understanding of Reality and Function at these levels. By examining Xiong's

187 Xiong, Weishixue gailun (1923), p. 129. 
views of suchness as Reality and consciousness as Function, section 2.1 argues that at the first level of his ti-yong system, Xiong presented Function as something that is provisionally established for the purpose of revealing Reality and, in so doing, he actually presented a Reality without Function (you ti wu yong 有體無用). Section 2.2 examines how Xiong understood productive power as Reality and manifest activity as Function. It argues that at the second level of his ti-yong system, Xiong presented Reality and Function as two aspects of the same thing: Reality is the intrinsic nature, the latent, and the potential, while Function is the external appearance, the manifest, and the actual. In this sense, the two are non-dual. The third section (2.3) of this chapter introduces Ouyang Jingwu's ti-yong perspective, which shares some similarities with Xiong's, and was probably an important source for Xiong's division of ti-yong into two levels. This introduction to Ouyang's idea, then, should elucidate Xiong's understanding of ti-yong.

This chapter concludes that it is mainly by drawing on the Madhyamaka doctrine of the two truths and Ouyang Jingwu's understanding of ti-yong that Xiong presented his two-level ti-yong system in the 1923 Weishixue gailun. Most of all, Xiong's adoption of the two-truth theory, which is actually a deviation from the Dharmapāla-Xuanzang tradition of Yogācāra, indicates his tendency to divide the ontological and the phenomenal into two distinct realms.

\subsection{Level 1: Suchness as Reality and Consciousness as Function}

\subsubsection{Consciousness as the Representation of the Phenomenal World}

In his 1923 Weishixue gailun, Xiong used the Yogācāra concept of consciousness to represent the phenomenal world. He achieved this primarily through his

elucidation of the Yogācāra theory of the "four parts" (si fen 四分) of cognition, through which he demonstrated that the phenomenal world is actually that as which consciousness manifests itself. Therefore, what follows looks closely at how Xiong interpreted this Yogācāra theory in his 1923 work. 
By following Dharmapāla's view, Xiong believed that consciousness includes four parts: the image part (xiang fen 相分; nimittabhāga), the perceiving part (jian fen 見分; darśanbhāga), the self-verifying part (zizheng fen 自證分; svasamvittibhäga) and the re-witnessing part (zheng zizheng fen 證自證分; svasamvitti-samvitti). His view of the relationship between consciousness and the phenomenal world is expressed through his explanation of the respective roles of these four parts and the relationship between them.

According to Xiong, "consciousness" received its name vis-à-vis its cognitive object (jing 境; vișaya). If there is no appearance of the cognitive object (jingxiang 境相), then how can the discrimination (fenbie 分別) be given rise to? ${ }^{188}$ This can be expressed another way, by referring to Jay Garfield's description: to be conscious is to be conscious of something; namely, consciousness always represents a relation between a sensory faculty and its object. ${ }^{189}$ That is to say, consciousness must involve two aspects, the cognising subject and the cognitive object.

For Xiong, the cognitive object is nothing but the image part into which consciousness transforms. ${ }^{190}$ This is because, according to Xiong, if there is no appearance of the cognitive object originally existing in the consciousness when the cognition occurs, then the cognitive object of the consciousness would be no different from anything not perceived by it. As a result, this consciousness should be unable to perceive its cognitive object for it would otherwise perceive all things at the same time. Moreover, if consciousness does not include the appearance of its cognitive object within it, then, for the cognitive object, this consciousness would be no different from other consciousnesses. Thus, other consciousnesses that perceive other things in other moments would also be able to perceive the cognitive

\footnotetext{
188 The original Chinese reads: “所云識者, 本對境受稱。若無境相, 焉起分別? ” Ibid., p. 137.

189 Jay Garfield, Engaging Buddhism: Why It Matters to Philosophy, New York: Oxford University Press, 2015, p. 131.

190 The original Chinese reads: “夫境者非伦, 即識所變之相分也。”Xiong, Weishixue gailun (1923), p. 137.
} 
object of this consciousness. 191 Consequently, Xiong showed that the cognitive object is not external to the consciousness that perceives it.

Xiong presented the cognising subject - namely, that which perceives objects - as the perceiving part of consciousness. According to him, if there is no characteristic as a perceiver in consciousness, then consciousness would be no different from space in this regard; and if this were the case, then consciousness would be unable to perceive any object - otherwise we would have to say that space can also perceive objects. ${ }^{192}$

Because the various objects of our consciousness are exactly those that constitute what we conceive as the "external world", as contrasted to the cognising self - the other aspect of the phenomenal world - Xiong actually suggested that the whole phenomenal world is subsumed within consciousness.

As such, Xiong's thought originates in and is consistent with Vasubandhu's and Dharmapāla's ideas. As Wu Rujun 吳汝鈞 (Ng Yu-kuan) points out, the world is usually divided into two aspects: the subjective self (zhuguan de ziwo 主觀的自 我) and the objective realm (keguan de shijie 客觀的世界). In Vasubandhu's Trimśikā, these two aspects are presented as "self" (wo 我; ātman) and "dharmas" (fa 法). For Vasubandhu, both "self" and "dharmas" are provisionally designated, since everything in the phenomenal world is produced through the transformation (zhuanbian 轉變; parịnāma) of consciousness and is therefore not real. Dharmapāla, as depicted in the Cheng weishi lun, further used the concept of the "perceiving part" to explain the "self" and the "image part" to explain "dharmas", arguing that these two parts of consciousness are erroneously taken as "self" and “dharmas" due to the discrimination (fenbie 分別) of consciousness. Accordingly, in Dharmapāla's thought, it is these two parts of consciousness that constitute the

\footnotetext{
191 Ibid., p. 61. Xiong's explanation originates in the Cheng weishi lun. For a discussion of Xuanzang's explanation of this view in the Cheng weishi lun, see Tao Jiang, Contexts and Dialogue, pp. 52-53. 192 Xiong, Weishixue gailun (1923), pp. 61-62. Again, Xiong's explanation originates in the Cheng weishi lun. See Tao Jiang's discussion of Xuanzang's view in his Contexts and Dialogue, p. 53.
} 
entire phenomenal world. ${ }^{193}$

Xiong did not stop at simply including the subjective self and the external world within consciousness as the perceiving part and the image part; by explaining the relationship between the two parts, he further demonstrated that these aspects of the phenomenal world are not distinct:

\section{自識謂見分，後隨文準知。親所緣，唯是自識所變。所變，謂相分。……心謂見 分, 下準知。親所緣, 定是不離自心之境, 謂相分是心之所變, 故不離心。故唯 識義成。當時大乘建立相分，實爲破小乘心外取境之利器。194}

What one's own consciousness That is, the perceiving part. It should be understood in the same way in what follows. directly takes as its object is only that into which one's own consciousness transforms. "That into which is transformed" refers to the image part. ... What the mind That is, the perceiving part. It should be understood in the same way below. directly takes as its object must be the cognitive objects that are not separate from one's own mind. That is to say, the image part is that into which the mind transforms and, thus, it is not separate from the mind. Accordingly, the meaning of "nothing but consciousness" is demonstrated. Mahāyāna's establishment of the image part at that time is really a sharp weapon to refute Hīnayāna's [view] that there are cognitive objects outside the mind.

As Xiong explained in the auto-commentary, "consciousness" and "mind" refer here specifically to the perceiving part, which indicates that the image part is that into which the perceiving part transforms and is, therefore, not separate from the perceiving part.

In the text following the above quotation, Xiong elaborated on the non-duality of the perceiving part and the image part:

\footnotetext{
193 Wu Rujun, Weishi xianxiangxue, pp. 17-22.

194 Xiong, Weishixue gailun (1923), p. 61.
} 
上述相見本非截然兩物，截然者，相離義。相托見生，見帶相起故。帶有二 義, 解胃《四緣章》所緣緣中。195

The image part and the perceiving part described above are originally not two distinct things. "Distinct" means "separate from one another". This is because the image part depends on the perceiving part to be generated, and the perceiving part arises by conveying the image part. "To convey" has two senses: see the explanation in [my discussion of] "the conditions enabling the mental appropriation of cognitive objects" (älambana-pratyaya) in "Si yuan zhang" 四緣章 (Chapter on four conditions). ${ }^{196}$

Xiong's claim that the image part depends on the perceiving part for its generation is unproblematic. As we have seen, he believed that the image part is that into which the perceiving part transforms; it is not separate from the perceiving part. Yet, his idea that the perceiving part arises by "conveying" (dai 帶) the image part only becomes clear in the context of a later chapter, to which he refers in his autocommentary.

There, Xiong gives the two senses of "to convey" as "to transform by conveying" (biandai 變帶) and "to carry" (xiedai or jiadai 挾帶). Concerning the former, "to transform by conveying", Xiong stated:

第一義者, 謂能緣 心、心所。變帶所緣相狀, 名爲相分, 對疏緣本質云 影像相。或云親相分。197

\footnotetext{
195 Ibid., p. 62.

196 The "conditions enabling the mental appropriation of cognitive objects" or älambana condition (suoyuan yuan 所緣緣) is one of the "four kinds of condition" (si yuan 四緣). The other three kinds are "causes as condition" (yin yuan 因緣; hetu-pratyaya), "continuous sequence of sameness condition" (deng wujian yuan 等無間緣; samanantara-pratyaya) and "contributory factors as condition" (zengshang yuan 增上緣; adhipati-pratyaya). As John Makeham points out, these four kinds of condition are crucial to Yogācāra accounts of causality, in particular the causal relationship between seeds, consciousness and cognitive objects. See Makeham (trans. and annot.), New Treatise on the Uniqueness of Consciousness, p. xxxiii. For another discussion of the "four kinds of condition", see, for example, Tao Jiang, Contexts and Dialogue, pp. 71-76.
}

197 Xiong, Weishixue gailun (1923), p. 104. 
The first sense means that the perceiver The mind and mental associates (caitta). ${ }^{198}$ is transformed by conveying the appearance of the ālambana, and is called the image part. In relation to the basic stuff (bimba) ${ }^{199}$ of the remote [ālambana] condition, 200 it is called the reflected image aspect. Some call it the direct image part. ${ }^{201}$

According to this sense of "to convey", Xiong's claim in the earlier quotation that "the perceiving part arises by conveying the image part" again emphasises the point that the perceiving part transforms into the image part.

As for the second sense of "to convey" - that is, "to carry" - Xiong stated: 第二義者, 謂能緣挾帶所緣體相而起。如見緣相親挾此相, 不更托此 相而重變相以緣也。故相見相望中無間隔亦復以此，能所冥合，得成

198 The "mind" here refers to the overall cognitive function of the consciousness. "Mental associates" (xinsuo 心所; caitta) are the mental functions, workings and activities related to and accompanying the mind. For an explanation of "mental associates", see Powers, "Yogācāra: Indian Buddhist Origins", pp. 44-45.

199 Drawing on A. Charles Muller's definition of benzhi 本質, John Makeham explains that the "basic stuff" (benzhi 本質; bimba) is the raw sensate aspect of something that impinges on our consciousness; the original form of something as contrasted to its reflected image in our consciousness; a substance as it is before it undergoes the transformations of consciousness and, thus, the raw substance of something that cannot ever be directly received but can only be "represented". Makeham, “The Significance of Xiong Shili's Interpretation of Dignāga's Ālambanaparīkșā (Investigation of the Object)", pp. 211-212.

200 Xiong divided the ālambana condition into a direct (qin 親) and a remote (shu 疏) kind. According to him, the direct ālambana condition refers to the kind that is not separate from the perceiver (nengyuan 能緣). It is what the perceiver is cognitively concerned about (suolü 所慮) and depends on (suotuo 所托). The remote ālambana condition refers to the kind of ālambana that is separate from the perceiver yet, as the substance (zhi 質) [bimba], can give rise to what the perceiver is cognitively concerned about and depends on. See Xiong, Weishixue gailun (1923), pp. 103, 109-111. Xiong's view of the two kinds of a lambana condition originates in the Cheng weishi lun. For a translation and discussion of Xuanzang's relevant statement in the Cheng weishi lun, see Makeham, "The Significance of Xiong Shili's Interpretation of Dignāga's Ālambana-parīkșā (Investigation of the Object)", p. 212.

201 I consulted John Makeham's translation of this statement. See his original translation in ibid., p. 211. 
證量。即現量。202

The second sense means that the perceiver arises by carrying the image of the perceptual object itself. It is like when the perceiving part takes the image part as its cognitive object, it directly conveys this image part, and does not further rely on this image part and then again transform itself into an image as its cognitive object. Therefore, there is no mediation in the mutual encounter between the image part and the perceiving part. It is also because of this that the subject [the perceiving part] and the object [the image part] are perfectly united, based on which valid cognition That is, direct perception (pratyakșa-pramāna). ${ }^{203}$ is established. 204

As Makeham explains, this statement shows that the perceiving part is directly aware of the image part without having to create a doubly transformed image by relying on the image part.205 In this sense of "to convey", Xiong's assertion that "the perceiving part arises by conveying the image part" reinforces the point that the two are not separate.

By means of the above elaboration of the relationship between the perceiving part and the image part, Xiong demonstrates that the subjective self and the external world are an indivisible unity.

As I explain below, for Xiong, the fundamental cause of the non-duality of self

\footnotetext{
202 Xiong, Weishixue gailun (1923), p. 105.

203 “Direct perception” (xianliang 現量; pratyakșa-pramāna) is what Dignāga believed to be one of the two valid sources of knowledge. It refers to the kind of knowledge obtained directly through the senses. The other valid source of knowledge is logical inference (biliang 比量; anumāna-pramāna), which refers to the kind of knowledge obtained by inference. See Shi Cun 石村, Yinming shu yao 因 明述要 (Summary of Buddhist logic), Beijing: Zhonghua shuju, 1981, pp. 45, 47, 118-127.

204 I consulted Makeham's translation of these sentences. See his original translation in "The Significance of Xiong Shili's Interpretation of Dignāga's Ālambana-parīkșā (Investigation of the Object)", p. 217.

205 Ibid., pp. 217-218. For a detailed discussion of the two senses of "to convey", see the same essay, pp. 211-218.
} 
and the external world is that both are derived from the transformation of consciousness. This point is shown by his elucidation of the relationship between the perceiving part and the image part and consciousness itself. According to Xiong, both the perceiving part and the image part are only two functions (gongyong 功 用), and so there must be a reality ( $t i$ 體) upon which the two parts rely. The selfverifying part, another part of consciousness, was established due to this consideration. ${ }^{206}$ Xiong's view indicates that what the perceiving part and the image part denote are merely activities of consciousness, and the self-verifying part was established to highlight the aspect of consciousness itself (ziti 自體).

The relationship between the self-verifying part, the perceiving part and the image part can be seen clearly in Xiong's elucidation of the Yogācāra theory of the transformation of consciousness. According to Xiong, this Yogācāra theory, which originated in Vasubandhu's Triṃsikā, introduces three interpretations, each presented by a different Yogācāra master: (1) There is only the self-verifying part of consciousness but no perceiving or image part. The reality of consciousness - the self-verifying part - transforms into two parts, yet neither has a [self-]nature ([zi]ti [自]體) because both are only imaginative constructions (bianji suozhi 遍計所 執). ${ }^{207}$ This idea was advocated by Sthiramati (Anhui 安慧, seventh century). ${ }^{208}$ (2) There is only the perceiving part and the image part but no self-verifying part. Because the image part is that into which the perceiving part transforms, it is said

\footnotetext{
206 Xiong, Weishixue gailun (1923), p. 62.

207 The "imaginative construction" refers to the "nature of existence produced from attachment to imaginatively constructed discrimination", one of the "three natures" of existence in Yogācāra philosophy.

208 In fact, the "two parts" in Sthiramati's texts are called "the part of the perceiver" (nengqu fen 能 取分) and “the part of that which is perceived" (suoqu fen 所取分) rather than "perceiving part" and "image part". Althought sounding similar, whether "the part of the perceiver" and "the part of that which is perceived" in Sthiramati's thought are equivalent to the "perceiving part" and "image part" in the Cheng weishi lun remains open to question. See Cao Zhicheng 曹志成, “Hufa Xuanzang yixi yu Anhui yixi dui shi zhuanbian zhi jieshi de bijiao yanjiu” 護法-玄牀一系與安慧一系對識轉變之解釋 的比較研究 (A comparative study between the Dharmapāla-Xuanzang tradition and the Sthiramati tradition on their explanations of "the transformation of consciousness"), Yuanguang foxue xuebao 圓光佛學學報, issue 2, October 1997, p. 84.
} 
that "there is nothing but consciousness" (weishi 唯識; vijñaptimatra). This idea was advocated by Nanda (Nantuo 難陀, sixth century). ${ }^{209}$ (3) The self-verifying part of consciousness is dependent arising in nature (yita xing 依他性). ${ }^{210}$ It transforms into a perceiving part and an image part, which are also dependent arising in nature. This idea was advocated by Dharmapāla. 211

Of these versions, Xiong followed Kuiji's opinion that Dharmapāla's interpretation is the correct one. ${ }^{212}$ Xiong interpreted this version as:

謂一識體，即自證分，亦云自體分。現起二用：即見有能緣用，相有質礙用 等。實根塵相分, 即有質礙, 自餘不爾。故致等言, 俟《境識》章詳之。用不離體, 體 必有用。213

That is to say, the reality of one consciousness That is, the self-verifying part, which is also called "the part of [consciousness] itself". manifests itself as two functions: the perceiving part has the function of perceiver, and the image part has the function of offering physical resistance, etc. The substantial faculties (indriya) ${ }^{214}$ and dusts (viśaya) ${ }^{215}$ as the image part indeed

209 Nanda was an important Yogācāra master in India.

210 The "dependent arising in nature" refers to the "nature of existence arising from causes and conditions", one of the "three natures".

211 Xiong, Weishixue gailun (1923), pp. 55-56.

212 Ibid., p. 56.

213 Ibid.

214 “Faculties” (gen 根; indriya) refer to the visual faculty (yan gen 眼根; cakșurindriya), the auditory faculty (er gen 耳根; śrotrêndriya), the olfactory faculty (bi gen 鼻根; ghrānêndriya), the gustatory faculty (she gen 舌根; jihvêndriya) and the tactile faculty (shen gen 身根; kāyêndriya). These five faculties are the most valuable part in the human body without which we cannot be living things (shengji ti 生機體). They are also, respectively, that which the visual, auditory, olfactory, gustatory and tactile consciousnesses rely on. However, these five faculties should be differentiated from the five physical organs, eye (yan 眼), ear (er 耳), nose (bi 鼻), tongue (she 舌) and body (shen 身), which are called “the matters that support the five faculties" (fu gen chen 扶根塵 or fu chen gen 扶塵根). Although the five faculties are categorised into the group of material dharmas (sefa 色法; rūpa) in Buddhism, unlike the five physical organs, they are not really material but something that is neither material nor mental. See Xiong, Fojia mingxiang tongshi 佛家名相通釋 (Complete explanation of Buddhist terms), in Xiong Shili quanji, vol. 2, pp. 363-365.

215 “Dusts” (chen 塵; viśaya) refer to form (se 色; rūpa), sound (sheng 聲; śabda), odor (xiang 香; 
offer physical resistance. Yet other things [as the image part] are not so. Thus, I added "etc." here and wait to elaborate on this in the chapter on "Jing shi" 境識 (Objects and consciousness). The functions are not separate from the reality, and the reality must have the functions.

In this statement, the relationship between the self-verifying part, the perceiving part and the image part is explained in terms of the ti-yong conceptual polarity: the self-verifying part is the reality of consciousness or consciousness itself, and the perceiving part and the image part are its two functions. The reality and the functions are indispensable to each other. In this way, the self-verifying part and the other two parts are presented as mutually entailing. This is consistent with Dharmapāla and Xuanzang's view in the Cheng weishi lun, which considers the perceiving part and the image part to be characteristics inherent in consciousness and, together with the self-verifying part, not external to each other. ${ }^{216}$

With this application of ti-yong, Xiong negated the views of both Sthiramati and Nanda. That is to say, since the perceiving part and the image part are two functions in which the self-verifying part is manifested, if the self-verifying part is existent, then the other parts cannot be imaginary and thus non-existent. Also, since the perceiving part and the image part are only two kinds of function, then they cannot be without a reality. Thus, Xiong endorsed Dharmapāla's view, which shows that all three parts - the perceiving part, the image part and the self-verifying part - are existent, albeit as dependent arising.

In relation to the argument that Xiong used consciousness to represent the phenomenal world, what is the significance of his adoption of Dharmapāla's

gandha), flavour (wei 味; rasa) and tactility (chu 觸; spraștavya). These five kinds of dust are that which the five faculties and the five corresponding consciousnesses perceive. According to Xiong, among these dusts, the category of form includes seeds. However, unlike other forms, seeds do not offer physical resistance. Ibid., pp. 365-369. This should be the reason Xiong, in this quotation, modified faculties and dusts with the word "substantial", by which seeds are excluded.

216 See Tao Jiang's discussion of Dharmapāla and Xuanzang's view in his Contexts and Dialogue, pp. 51-55. 
interpretation of the "transformation of consciousness" rather than the interpretations attributed to Sthiramati and Nanda? As already noted, what the perceiving part and the image part represent are actually the "self" and "dharmas", the two aspects of the phenomenal world. Sthiramati's view seems to indicate that the transformation of consciousness into the phenomenal world is imaginary. Although Nanda explained the relationship between the perceiving part and the image part in such a way as to show that "there is nothing but consciousness", from Xiong's perspective his view lacks a common basis for these two parts because Xiong believed that both were only functions. Dharmapāla's account makes up for the deficiency in Nanda's view by showing that the self and the external world are the result of the bifurcation of consciousness, and thus providing the two aspects of the phenomenal world with a common reality. Xiong's resort to the ti-yong conceptual polarity to interpret Dharmapāla's perspective indicates his own view that the phenomenal world is not different from consciousness.

As for Xiong's application of the ti-yong conceptual polarity in the above statement, obviously, the ti and yong in that context do not mean the Reality of the universe and its Function but are used only to explain the relationship between the self-verifying part, the perceiving part and the image part within a single consciousness. This kind of usage of ti-yong - that is, only to explain the non-dual relationship between things - appears sometimes in Xiong's 1923 work, ${ }^{217}$ and it indicates that his later emphasis on the non-duality of Reality and Function has its roots in Yogācāra.

In addition to its role as the basis on which the perceiving part and the image part rely, Xiong gave two further reasons why the self-verifying part is theoretically required. First, every moment of consciousness needs to be aware of itself if memory or recollection of that moment is to be possible (otherwise, as Makeham

\footnotetext{
217 Yet, after Xiong began to establish his own ti-yong philosophical system in his 1926 writing, he commonly used the concepts of $t i$ and yong to exclusively mean the Reality of the universe and its Function.
} 
explains, there would be just an array of unconnected moments). Because the perceiving part cannot perceive itself, the self-verifying part was established as that which is aware of its perception of the image part. ${ }^{218}$ Second, from an epistemological perspective, the perceiving part itself cannot know the result of its own perception, just like a ruler can measure but cannot know the result of the measurement. Thus, the self-verifying part was established as that which knows the result of the perception by the perceiving part. ${ }^{219}$ It can be seen that both reasons show the role of the self-verifying part as that which is aware of the perception of the image part by the perceiving part. Since both the image part and the perceiving part are essentially not different from the self-verifying part, consciousness is aware of itself. 220

The establishment of the re-witnessing part, another one of the four parts of consciousness, is similar to that of the self-verifying part, given in the second reason above. That is to say, since the self-verifying part cognises the perceiving part, just as the perceiving part's perceiving the image part, there should also be a part of consciousness that can know the result of its cognition. The perceiving part cannot take this role, since the cognition of the role must only be direct perception given that this role is to realise the appearance of consciousness itself (zixiang 自相; svalakșana). However, in addition to being direct perception, the cognition of the perceiving part can also be logical inference (biliang 比量; anumāna-pramāna) or

\footnotetext{
218 For an explanation of the self-verifying part on this point, see Makeham, "The Significance of Xiong Shili's Interpretation of Dignāga's Ālambana-parīkșā (Investigation of the Object)", p. 223, note 18; Tao Jiang, Contexts and Dialogue, p. 54.

${ }^{219}$ Xiong, Weishixue gailun (1923), pp. 62, 63. For a detailed discussion of the self-verifying part in the Cheng weishi lun, see Mao Yufan 茅宇凡, “Weishixue zizheng lilun zhi yanjiu: yi Cheng weishi lun wei zhongxin” 唯識學 “自證” (svasamvitti) 理論之研究——以《成唯識論》爲中心 (A study on the Yogācāra theory of self-verification [svasamvitti]: with a focus on the Treatise Demonstrating Nothing but Consciousness), Zhonghua foxue yanjiu 中華佛學研究, no. 11, 2010, pp. 141-169.

220 On the idea of the reflexivity of consciousness in Yogācāra philosophy, see Jay Garfield's discussion of the arguments of Dignāga, Vasubandhu's student whose idea of the three parts (the image part, the perceiving part and the self-verifying part) of consciousness was developed by Dharmapāla. Garfield, Engaging Buddhism, pp. 136-139.
} 
incorrect cognition (feiliang 非量; apramāṇa). Therefore, Dharmapāla theoretically established the re-witnessing part to fill the role of that which is aware of the cognition by the self-verifying part. According to Xiong, the self-verifying part in turn acts as the part aware of the cognition by the re-witnessing part. Thus, there is no need to establish another part, which avoids the "mistake of endless regress" (wuqiong guo 無窮過). ${ }^{221}$ Above all, both the cognitions of the self-verifying part and of the re-witnessing part do not exceed the stipulation that there is no external object to be perceived by consciousness. They therefore reinforce the perspective that the only thing consciousness perceives is itself.

Having made clear the roles of all four parts of consciousness and the relationship between them, Xiong emphasised that they are an integrated whole:

一切心、心所, 各各四分合成, 四分相望, 不即不離。據功用別, 名 爲非即; 四用一體, 名爲非離。雖相別種, 仗見生故, 非不一體。又此四分, 或攝爲三，第四攝入自證分故; 即唯有相、見、自證三分。或攝爲二，後三 俱是能緣性故, 皆見分攝; 即唯有見相二分, 然此與《攝論》及難陀等之主張不同, 彼未分析四分而主唯二, 此則先行分析, 而後駅之以簡也。或攝爲一，相離見無別體 故, 總名一識。此言識者, 通心、心所。222

Each mind and mental associate is composed of four parts. The four parts are interrelated, neither identical nor separate. They are differentiated according to their functions, and [so] are said to be "nonidentical"; the four functions are one body, and [so] are said to be "nonseparate". Although the image part has a different seed, it depends on the perceiving part for generation, and so it is indeed one body [with the other three parts]. Furthermore, these four parts can either be merged into three, since the fourth [the re-witnessing part] can be included within the self-verifying part; That is, there is only the image part, the perceiving part and the self-verifying

\footnotetext{
221 Xiong, Weishixue gailun (1923), p. 63.

222 Ibid., p. 65.
} 
part. or merged into two, since the latter three [the perceiving part, the self-verifying part, and the re-witnessing part] all possess the characteristic of perceiver and thus all can be included within the perceiving part; That is, there is only the perceiving part and the image part. However, this is different from such propositions as that in Mahāyānasaṃgraha-śāstra (She dasheng lun 攝大乘論; Compendium of the Great Vehicle) ${ }^{223}$ and that of Nanda. They did not divide [consciousness] into four parts but proposed only two. Yet here I divide [consciousness into four parts] first, before subjecting them to differentiation. or merged into one, since the image part has no other reality without the perceiving part. [Therefore, the four parts] are, together, called a whole consciousness. Here "consciousness" refers to both the mind and the mental associates.

This shows Xiong's view that the four parts of consciousness refer only to the four functions of consciousness, and that they are fundamentally a single whole. It is precisely based on the respective features of their functions that Xiong finally integrated the four into one. That is, the re-witnessing part can be included in the self-verifying part because both are the function of the reflexive awareness of consciousness; the re-witnessing part and the self-verifying part can be included into the perceiving part because all three are the function of perceiving objects; and the image part, of course, can also be included within the perceiving part because it is that into which the perceiving part transforms. Therefore, ultimately, there is only one function of consciousness - to perceive objects. In this way, the four parts are integrated into one and subsumed under the term "consciousness".

Above all, by explaining the four parts of consciousness, especially the transformation of consciousness into a perceiving part and an image part, Xiong successfully identified the phenomenal world to the realm of consciousness (all phenomena are derived from the transformation of consciousness) and showed

223 Mahāyānasamgraha-śāstra is a seminal text in the Yogācāra school, ascribed to Asañga. 
that there is no cognitive object separate from or external to consciousness. ${ }^{224}$ Because the realm of consciousness is the phenomenal world, the concept of consciousness can be used to represent it. This is why, when Xiong talked about Reality and Function in his 1923 work, he regarded consciousness as Function, as we will see later in this chapter.

\subsubsection{The Characteristics of Consciousness}

An important characteristic of consciousness in Xiong's 1923 Weishixue gailun is “arising and ceasing” (sheng mie 生滅). According to Xiong, the transformation of consciousness discussed above - the self-verifying part/the reality of consciousness/consciousness itself transforms into a perceiving part and an image part - "suddenly arises and suddenly ceases" (dun qi dun mie 頓起頓滅). ${ }^{225}$ Obviously, consciousness here refers to a single moment of consciousness. This means that every moment consciousness manifests itself as the phenomenal world and immediately disappears. Xiong did not directly elucidate the arising and ceasing of consciousness, but he did discuss this characteristic of phenomena or dharmas. ${ }^{226}$ Since consciousness is manifested in phenomena/dharmas, Xiong's discussions of the latter's arising and ceasing can be considered to be his discussions of this characteristic of the former.

According to Xiong, conditioned dharmas "cease as soon as they arise" (cai sheng ji mie 䌆生即滅). ${ }^{227}$ Although this seems to emphasise the final extinction of

\footnotetext{
224 To say that the phenomenal world is not outside consciousness is not necessarily to deny the possibility of an external world. Yet, as in Xuanzang's view, the reality of this "external world" cannot be ascertained independently of consciousness - what we can know is only internal to our consciousness - and so it is not necessary to posit such an "external world". See Tao Jiang, Contexts and Dialogue, pp. 56-57.

225 Xiong, Weishixue gailun (1923), p. 56.

226 It should be noted that in Xiong's discussions on this issue, "phenomena" or "dharmas" refer to all phenomena/dharmas as a group within a single conscious moment.

227 According to Xiong's explanation in an auto-commentary, the various material and mental dharmas arise and cease, and so are said to be conditioned (色心諸法, 有起滅故, 名有爲). Ibid., p. 57.
} 
dharmas, what Xiong really wanted to express is that there are always new dharmas arising in the immediately succeeding moment. In his words, "we should know that 'suddenly ceasing' actually means ‘suddenly arising'” (應知頓滅, 實是頓生). ${ }^{228}$ In this way, dharmas existing in contiguous conscious moments are presented as continuously arising and ceasing without interval. This point is revealed clearly in Xiong's refutation of “eternalism” (chang jian 常見) and “nihilism” (duan jian 斷 見), two notions that the Mahāyāna Buddhists always criticise:229

\begin{abstract}
夫異生僻執, 有計諸法是常, 有計諸法是斷, 斯二皆過。故說䌆生即 滅, 念念盡故非常, 新新生故非斷。230

Unenlightened people have one-sided attachments. Some reckon that dharmas are eternal, and some reckon that they come to an end. Both attachments are mistakes. Thus, we say that [dharmas] cease as soon as they arise. Every moment they are extinguished, and so are not eternal; new [dharmas] are always generated [every moment], and so they do not come to an end.
\end{abstract}

To say dharmas are not eternal is to say they constantly cease; to say they do not come to an end is to say new dharmas constantly arise. What we consider to be a single entity in the phenomenal world is actually nothing but a continuum of momentary dharmas instantly ceasing while arising.

Xiong further illuminated this view when he again discussed the notions of "eternalism" and "nihilism" in his 1923 work:

\footnotetext{
228 This is a reply to an assumed criticism that Xiong noted in an auto-commentary, which says: “Wouldn't 'ceasing as soon as arising' be 'always ceasing'?” (絸生即滅者, 得非總是滅耶? ) Ibid.

229 As John Makeham explains: "Eternalism is the view that there are enduring existents (and is typically associated with the view that the self exists in life and persists after death); and nihilism or annihilationalism is the view that all things lack intrinsic reality (and is typically associated with the view that sentient beings cease when they die)." Makeham, "Xiong Shili's Understanding of the Relationship between the Ontological and the Phenomenal", in Chinese Metaphysics and Its Problems, eds. Chenyang Li and Franklin Perkins, p. 222.
}

230 Xiong, Weishixue gailun (1923), p. 59. 
迹世所謂物者, 稱實而談本無少物, 唯是一變一變之勢用。諸行於前刹那 總起便滅, 名為一變; 後刹那續前而起, 亦無間即滅, 又名為一變。變變相續, 非糹非 常。231

If we trace what is conventionally called "entity", the fact of the matter is that there has never been any entity. Rather, it is only the configuration of successive transformations. As soon as dharmas from a previous moment arise they cease, which is said to be "a single transformation"; and as soon as dharmas arise at the succeeding moment by continuing from the previous moment they also cease without any interval, which, again, is called "a single transformation". Transformations succeed one another, and [dharmas] are neither interrupted nor eternal.

Here, the "entity" ( $w u$ 物) in the conventional view is presented as the configuration of successive transformations. In this context, "transformation" refers to dharmas' instantly ceasing while arising in a single moment. Thus, what Xiong intended to express is still the view that what we designate as an entity is actually a continuum of momentary dharmas. To describe the "entity" as a kind of configuration highlights that those "entities" in the phenomenal world are devoid of self-nature.

Since the arising and ceasing of dharmas represents the arising and ceasing of the momentary mind, the continuity of dharmas similarly reveals that our consciousness is not a single entity but rather a continuum of momentary thoughts that cease as soon as they arise. ${ }^{232}$ It is, therefore, devoid of self-nature.

\footnotetext{
231 Ibid., p. 213.

232 That consciousness can be a continuum of momentary thoughts is due to two reasons. First, a seed, as the "cause as condition", can generate a succeeding seed of the same kind. Then there is a succession between these seeds. Also, a seed as the "cause as condition" can produce a momentary thought of the same nature, which exists simultaneously with it. Mediated by seeds, momentary thoughts are also successive. Second, the preceding momentary thought, as the "continuous sequence of sameness condition", passes into the succeeding momentary thought. See Tao Jiang, Contexts and Dialogue, pp. 71-73.
} 
Similarly, with the idea that dharmas cease as soon as they arise, Xiong made the point that they are stationary rather than moving:

\section{又即依據是理, 諸法無實動義。一刹那䌆生即滅, 前不待後, 此不至 彼, 各住本位。雖復幻相遷流, 實則自性湛寂。《肇論》。物不遷》一篇, 雖 宗三論, 讀者亦可參考。233}

Furthermore, according to this principle [that dharmas cease as soon as they arise], dharmas do not really move. In an instant they cease as soon as they arise. The preceding dharmas do not wait for the succeeding dharmas, and these dharmas do not move to [the moment of] those dharmas. They each stay in their own moments of occurrence. Although there are illusions that [things are] moving and flowing, in fact their natures are still. Zhao lun 肇論 (Essays by Sengzhao). Although the essay "Wu bu qian lun" follows the Three Treatise School, readers can also consult it.

Since dharmas cease as soon as they arise, they cannot move to another moment of occurrence but must stay at their own moment of occurrence. What we see as something that can move and change is therefore actually a continuum formed by momentary dharmas that are stationary. In other words, the "movements and changes" of an "entity" result from the continuous arising and ceasing of dharmas and are therefore illusory. Although things seem to be moving and changing, they are in fact tranquil.

It is worth noting that Xiong's above statement is obviously an adoption of Sengzhao's thesis. As discussed in the previous chapter, Sengzhao demonstrated in the "Wu buqian lun" that things remain in their moments of occurrence and do not move to other moments of occurrence. In his view, things do not move from the perspective of ultimate truth; while from the perspective of conventional truth, things "flow and move". It seems that Xiong used the idea that dharmas cease at the

233 Xiong, Weishixue gailun (1923), p. 59. 
very moment they arise to support Sengzhao's argument.

As Xiong noted, Sengzhao's "Wu buqian lun" accords with the doctrine of the Three Treatise School, a Chinese school of Indian Madhyamaka Buddhism. It follows that, by supporting Sengzhao's perspective, Xiong must have agreed with Madhyamaka to some extent. In this statement, for example, his expression that things are actually tranquil although they seem to be moving is apparently an adoption of Sengzhao's differentiation of the two truths, which originates in Madhyamaka philosophy.

What Sengzhao actually tried to argue, however, is that all things are impermanent since they only have provisional natures that are momentary. What is more, what Madhyamaka sought to prove by showing the lack of a permanent nature of things is an absolute or ultimate emptiness. ${ }^{234}$ In other words, both emphasised the final extinction of things. Yet Xiong's view in this regard differs from the perspective of Sengzhao and Madhyamaka because he not only pointed out the instant cessation of dharmas (dharmas are not eternal), but also emphasised the continuous arising of new dharmas (dharmas do not come to an end). Therefore, although in this case Xiong absorbed useful ideas from both, he did not give attention to what they tried to argue with these ideas.

In addition to his claim that dharmas (or consciousness that manifests as those dharmas) cease at the very moment they arise, Xiong identifies another characteristic of them when he explains how they are generated:

諸法無作者、無作用、無實自性, 唯依托眾緣而起, 故名緣起。緣者, 由義，藉義。凡法此由彼有，此即藉彼，亦或彼此互為由藉。235

Dharmas do not have a creator, function or real self-nature. They arise

\footnotetext{
${ }^{234}$ For a discussion of the Madhyamaka doctrine, see Zhihua Yao, "Yogācāra Critiques of the Two Truths", in A Distant Mirror: Articulating Indic Ideas in Sixth and Seventh Century Chinese Buddhism, eds. Chen-kuo Lin and Michael Radich, Hamburg: Hamburg University Press, 2014, pp. 316-317. 235 Xiong, Weishixue gailun (1923), p. 59.
} 
only by depending on a multitude of conditions (pratyaya), ${ }^{236}$ and so are called "dependent arising" (pratītya-samutpāda). "Condition" means "due to" and "rely on". For all dharmas, if this one exists due to that one, then this one relies on that one, or they both are due to and rely on each other.

In other words, all dharmas are generated through the aggregation of conditions and so are empty of intrinsic nature. Since dharmas are the manifestation of consciousness, and the arising of dharmas represents the arising of consciousness, this entails that the generation of consciousness is dependent on conditions.

In sum, in his 1923 work Xiong presented three main characteristics of consciousness: (1) it is a continuum of momentary thoughts that cease at the very moment they arise; (2) it is generated by the aggregation of conditions; and (3) both of these characteristics show that consciousness is devoid of self-nature.

\subsubsection{Xiong's Negation of the Existence of Consciousness}

Despite the many theories of consciousness, there is an indication that, for Xiong, consciousness was only theoretically established from the perspective of conventional truth. Indeed, as the following passage shows, he believed that the view that consciousness truly exists must be dispatched from the perspective of ultimate truth. In his 1923 work, Xiong discussed the meaning of "nothing but consciousness" (weishi 唯識; vijñaptimatra), an important idea in Yogācāra Buddhism. This idea means, on the whole, that what appears to us is constructed, projected and interpreted by our consciousness. As a result, nothing in the phenomenal world is beyond the realm of the activities of consciousness. ${ }^{237}$ In explaining "nothing but consciousness", Xiong said the following:

\footnotetext{
236 “Conditions" (yuan 緣; pratyaya) refer to the "four kinds of condition". Ibid. See Xiong's detailed explanation of the "four kinds of condition" in the same work, pp. 96-130.

237 For discussions of the Yogācāra idea of "nothing but consciousness", see Makeham, "Introduction", in Transforming Consciousness, ed. John Makeham, p. 22; Dan Lusthaus, "Yogācāra School", in Encyclopedia of Buddhism, ed. Robert E. Buswell, Jr., New York: Thomson Gale, 2004, vol. 2, pp. 917-918.
} 
法性離言, 心行路絕。識唯唯字倒用。寧立, 以對破眾生迷執, 假說唯識。 原夫凡外計有實我, 小宗如凟子部等, 亦計有我, 此唯叙凡外者, 凡外通故。爲說五 藴假名, 謂依色心五䌨棨, 假名曰我。小乘之徒, 又計有實法, 一說部於諸蓝 法, 說為但有假名, 頗接近大乘空教。今此據多分以言, 略而不簡。說法無自性, 無自 性者, 猶云無實自體, 諸有為法, 緣生如幻, 大乘以此破小。不了義大乘, 復蹈惡取 空, 清辨之徒, 言性相皆無, 以所執空為真理, 故以惡取呵之。以是攝法歸識, 色心 諸有為法, 真如無為法, 總說不離識。詳前。遣空有有者, 有我法。執。唯有識故, 說我 法如實是無。亦唯有識故, 但空依識所起我法執, 而識性相非空。故唯識之言, 空有雙遣。 若使諸執盡除, 唯識亦自不立。諸聞唯識教者, 教者言教。以爲實有建立, 有識可唯, 則亦成法執, 同於所破。238

If the dharma-nature cannot be expressed in words, The path for mental activities has stopped. how can the theory of "nothing but consciousness" The character wei 唯 (only) is here used in reverse order. be established? To counter and refute the mistaken attachments of sentient beings, it is nominally said that there is nothing but consciousness. Originally, ordinary folk and non-Buddhists reckoned that there was a real self, Such Hīnayāna schools as Vātsīputrīya also reckoned that there was a self. The reason that I make reference only to ordinary folk and non-Buddhists here is that the term "ordinary folk and non-Buddhists" covers [such Hīnayāna schools as Vātsīputrīya]. and so for their sake the "five aggregates"239 and "nominal designation" (prajñapti) were explained; That is, the "self" is nominally designated on the basis of the accumulation of the five aggregates, such as the aggregates of form (rūpaskandha) and mind (vijñāna-skandha). Furthermore, followers of Hīnayāna reckoned that real dharmas exist, Ekavyāvahārika explained things formed by

\footnotetext{
238 Xiong, Weishixue gailun (1923), p. 50.

239 The "five aggregates" ( wu yun 五蓝) or “five skandhas” are: the aggregate of form (se yun 色蓝; rūpa-skandha), the aggregate of sensation (shou yun 受蓝; vedana-skandha), the aggregate of perception (xiang yun 想蘊; samjñā-skandha), the aggregate of volition (xing yun 行蓝; sampskāraskandha) and the aggregate of mind (shi yun 識蓝; vijñanna-skandha). For a discussion of these aggregates, see Yu Lingbo, Weishi sanlun jin quan, pp. 85-88.
} 
aggregates as having only nominal designations, ${ }^{240}$ which is quite similar to the Madhyamaka school of Mahāyāna Buddhism. Here this statement [that followers of Hīnayāna reckoned that real dharmas exist] is based on the majority view [held by followers of Hīnayāna], and so [Ekavyāvahārika's view] is left out and will not be reviewed. [and it was for their sake that] dharmas' lack of self-nature was explained. "Lacking self-nature" is like saying "lacking real self-entity". The various conditioned dharmas are generated by conditions and are like illusions. Mahāyāna refuted Hīnayāna with this idea. Those Mahāyāna Buddhists who did not fully comprehend this meaning again turned towards a pernicious attachment to "emptiness" (śūnyatā). The likes of Bhāviveka (Qingbian 清辨, ca. 490-570) ${ }^{241}$ said that both the nature and the characteristic [of phenomena] were non-existent, and they regarded the "emptiness" to which they were attached as the truth. Therefore, they were rebuked for "pernicious attachment". Therefore, dharmas were subsumed within consciousness, The various conditioned dharmas, that is, material and mental dharmas, and the unconditioned dharma, that is, suchness, were all said not to separate from consciousness. Details above. [with the purpose of] dispatching both attachment to emptiness and to existence. "Existence" refers to the existence of self and dharmas. Because there is nothing but consciousness, self and dharmas are said to be truly non-existent. Also, because there is nothing but consciousness, only the attachment to self and dharmas, generated in dependence on consciousness, is emptied, yet the nature and the characteristic of consciousness are not empty. Therefore, by saying that there is nothing but consciousness, both [the attachments to] emptiness and to existence are dispatched. If all attachments have been completely eliminated, then the theory of "nothing but consciousness" would automatically be invalid as well. If those who hear about the teaching of "nothing but consciousness" "Teaching" means "verbal teaching". take it to mean that

240 Ekavyāvahārika is one of the Hīnayāna schools.

241 Bhāviveka was an influential Madhyamaka scholar in India. 
there is really something that has been established [as consciousness] so that there is consciousness that can be taken to be the only existent thing, then this also becomes an attachment to dharmas and is the same as that which is refuted.

For Xiong, the theory of "nothing but consciousness" is only nominally (jia 假; prajñapti) spoken of from the perspective of conventional truth for the purpose of refuting both claims: that there exist real self and real dharmas and that there is nothing but "emptiness". From the perspective of ultimate truth, however, consciousness does not truly exist, either. This seems to indicate that consciousness was only provisionally established as a steppingstone to the revelation of the ultimate truth, and that the theory of "nothing but consciousness" is merely a skillful means (fangbian 方便; upāya) of refuting false attachments. Presumably, Xiong felt able to claim that after those attachments have been eliminated, the theory of "nothing but consciousness" would be rendered invalid because he considered consciousness to be no different from self and dharmas; all are only imaginary and nominal designations (jiaming 假名; prajñapti) and thus do not really exist. This is probably why he said that if one regarded consciousness as existent, then this would be an attachment to dharmas. In this way, Xiong seems to have included all his other discussions on consciousness, whether presenting it as a continuum of arising and ceasing or as dependent arising, within a broader theoretical agenda.

If this is the case, then it reveals a divergence between Xiong's view and the Xuanzang-Kuiji tradition of Yogācāra. At the beginning of Cheng weishi lun, Xuanzang discussed the misunderstandings of the theory of "nothing but consciousness" that his treatise sought to clarify:

復有迷謬唯識理者, 或執外境如識非無, 或執內識如境非有。242

242 Xuanzang 玄牀, Cheng weishi lun 成唯識論 (Treatise demonstrating nothing but consciousness), vol. 1, in the CBETA edition of the Taishō Tripițaka, T31n1585_001, 0001a07. 
Moreover, there are those who are confused about the principle of "nothing but consciousness". Some are attached to [the view] that external objects are like consciousness and thus are not non-existent. Some are attached to [the view] that internal consciousness is like external objects and thus is not existent. ${ }^{243}$

By regarding this as a misunderstanding, Xuanzang simply distinguished between consciousness and external objects: the former exists, the latter do not. But since the existence of consciousness is expressed in relation to the nonexistence of external objects, what does "existence" mean and to what extent can consciousness be said to be existent?

When discussing the transformation of consciousness - the reality of consciousness transforms into a perceiving part and an image part, based on which self and dharmas are provisionally designated - later in the Cheng weishi lun, Xuanzang offered an explanation of the above point:

\section{外境隨情而施設故非有如識。內識必依因緣生故非無如境。由此便遮 增減二執。境依內識而假立故唯世俗有, 識是假境所依事故亦勝義有。 244}

External objects are provisionally established according to false discriminations, and so they do not exist like consciousness; to arise, internal consciousness must depend on causes and conditions, and so, unlike objects, it is not non-existent. Accordingly, the two attachments to existence and to emptiness are refuted. Objects are posited depending on internal consciousness, and so they exist only from the perspective of conventional truth; consciousness is that which nominal objects depend on, and so it exists also from the perspective of ultimate

243 This is not saying that consciousness can be divided into the internal and the external. The "internal" consciousness is only termed thus in distinction to "external" objects.

244 Ibid., $0001 \mathrm{a} 23$. 
truth.

As for the reason external objects are non-existent while consciousness exists, it is clear that Xuanzang resorted to the differentiation between the "nature of existence produced from attachment to imaginatively constructed discrimination" and the "nature of existence arising from causes and conditions", the first and second natures in the Yogācāra doctrine of "three natures". The "nature of existence produced from attachment to imaginatively constructed discrimination" refers to the nominal designations (that is, what we conceptualise things to be), which are mistakenly considered to be real but which are, in fact, imaginatively constructed. The "nature of existence arising from causes and conditions" refers to the fact that conditioned dharmas are generated depending on causes and conditions. Although these dharmas do not have self-nature, they still arise and are not non-existent. ${ }^{245}$ In Xuanzang's statement, external objects are provisionally established according to false discriminations, which means that they are only nominal designations and imaginative constructions. Thus, they do not truly exist. By contrast, consciousness is generated by causes and conditions and so, although it is devoid of self-nature, it is not non-existent. ${ }^{246}$ Further, for Xuanzang, because external objects are posited based on the transformation and the discrimination of consciousness, they are said to be real only from the perspective of conventional truth. Yet consciousness is the basis of these provisional objects, and so it can be said to exist even from the perspective of ultimate truth.

Some scholars consider Xuanzang's claim that consciousness exists even from the perspective of ultimate truth to be problematic. For example, Wu Rujun believes that since consciousness arises depending on causes and conditions and is

\footnotetext{
245 For a discussion of the "three natures", see Yu Lingbo, Weishi sanlun jin quan, pp. 233-237.

246 Tao Jiang notes that Xuanzang categorised things into two kinds, real and nominal. For Xuanzang, both seeds and consciousness, which are, respectively, considered to be potential and actual, are regarded as real, but the nominal is regarded as merely fictional, hence unreal. See Tao Jiang, Contexts and Dialogue, p. 60. For Xuanzang's views on "real" and "nominal", see also Lusthaus, Buddhist Phenomenology, pp. 452-455.
} 
thus devoid of self-nature, it cannot be said to be existent at the level of ultimate truth but existent only when compared to provisional objects. Therefore, the term “ultimate truth" (shengyi 勝義) in Xuanzang's statement is probably inappropriate and should not be interpreted in its normal sense. ${ }^{247}$ Although this view sounds reasonable, there is still a possible explanation for Xuanzang's claim. That is, when Xuanzang said that consciousness exists from the perspective of ultimate truth, here "consciousness" refers not to the linguistic entity under its name but to its status as dependent arising, which is true even from the perspective of ultimate truth.

In any case, in the Cheng weishi lun, consciousness is presented as having a different character from external objects: the former is generated by causes and conditions, while the latter is imaginatively constructed. This differs from Xiong's view in his statement concerning the meaning of "nothing but consciousness" quoted above, which seems to consider consciousness to be no different from self and dharmas. That is, all are imaginary and provisionally established. ${ }^{248}$

In fact, Xuanzang's Cheng weishi lun does have a passage that reads like, but actually has a different meaning from, Xiong's:

諸心心所依他起故，亦如幻事，非真實有。爲遣妄執心心所外實有境

故，說唯有識。若執唯識真實有者，如執外境，亦是法執。249

247 See Wu Rujun, Weishi xianxiangxue, pp. 24-25. For another explanation of the problem of Xuanzang's expression, see Yu Lingbo, Jianming Cheng weishi lun baihua jiangji 簡明成唯識論白話 講記 (A concise and vernacular explanation of the Treatise Demonstrating Nothing but Consciousness), available at: http://www.book853.com/wap.aspx?nid=1551\&p=1\&cp=5\&cid=91, accessed August 5, 2018.

248 Although, as discussed in this chapter, Xiong indicated the characteristic of dependent arising of consciousness elsewhere in his 1923 work, from his statement concerning the meaning of "nothing but consciousness" quoted earlier, there is clearly the possibility that in his view, this idea, along with all other theories of consciousness, is confined to a theoretical agenda.

249 Xuanzang, Cheng weishi lun, vol. 2, in the CBETA edition of the Taishō Tripițaka, T31n1585_002, $0006 c 21$. 
Because minds and mental associates arise in dependence on other things, they are indeed like illusions and are not truly existent. To dispatch the false attachment to [the view] that objects outside minds and mental associates truly exist, it is said that there is nothing but consciousness. If one is attached to [the view] that "nothing but consciousness" is really true, then this is like being attached to [the existence of] external objects and is also an attachment to dharmas.

This passage refers to the "lack of nature in that which is produced by causation", one of the "three kinds of absence of nature", a theory derived from the "three natures". That is, since consciousness (minds and mental associates) arises depending on other things (causes and conditions), it is devoid of self-nature. In this regard, Xuanzang considered consciousness not to truly exist. However, this only shows that Xuanzang considered consciousness not to exist as a substantial entity; it does not mean that he considered it not to exist as something that dependently arises. If one takes consciousness to be a substantial entity, then this is similar to endowing consciousness with a "nature produced from attachment to imaginatively constructed discrimination". Therefore, Xuanzang argued that if one believes that consciousness really exists, then this is similar to insisting on the existence of external objects.

Xuanzang's view has a subtle but important difference from Xiong's. Xuanzang did not negate the existence of consciousness as dependently arisen (although he did negate it as a substantial entity). By contrast, Xiong, indiscriminately and vaguely, took consciousness to be fictional, no different from self and dharmas, which have only the first nature of existence.

It can be seen from Xuanzang's above statements that the issue of whether, and to what extent, consciousness exists should be understood by means of the theories of the "three natures" and the "three kinds of absence of nature". Xiong, for his part, did not expound at all on these two theories in his 1923 work, which is surprising, since, as we saw in the previous chapter, he already knew about the 
theory of "three natures" and quite favoured it before 1920. To say the least, it is unusual for him not have to mentioned it - especially for such a significant Yogācāra theory - when he elaborated on Yogācāra learning in the early 1920s. This indicates that there is at least the possibility that Xiong omitted this theory deliberately in his 1923 account of Yogācāra learning for fear that it would undermine his own view of consciousness.

Xiong's negation of the existence of consciousness seems to evidence a tendency towards Madhyamaka views to some extent. Both Madhyamaka and Yogācāra broadly maintain that conditioned dharmas are generated by conditions and thus do not have self-nature. However, as $\mathrm{Wu}$ Rujun points out, the emphases of these two schools differ, with the Madhyamaka school using the idea that all dharmas are devoid of self-nature to emphasise ultimate emptiness, and the Yogācāra school using the idea of "nothing but consciousness" to emphasise the dependent arising of phenomena. ${ }^{250}$ In fact, like Xuanzang, Yogācārins such as Asanga did not negate the existence of consciousness, albeit as dependent arising, whereas Mādhyamikas hold that all dharmas are but designations and thus empty. ${ }^{251}$ Xiong's use of consciousness as a nominal construction and the idea of "nothing but consciousness" as a skillful means by which to demonstrate that nothing exists emerges from the above distinction between Madhyamaka and Yogācāra as an application of the Yogācāra idea to interpret the Madhyamaka perspective.

Indeed, to some extent, Xiong's approach is similar to that of the attempt to syncretise Yogācāra and Madhyamaka by Śāntarakṣita (Jihu 寂護, 725-788). ${ }^{252}$ Śāntarakṣita first supported the Yogācāra idea of nothing but consciousness by rejecting the existence of external objects. He then applied Madhyamaka analysis to

\footnotetext{
250 Wu Rujun, Weishi xianxiangxue, p. 212.

251 See Yao, "Yogācāra Critiques of the Two Truths", pp. 316-317, 329-330.

252 Śāntarakşita was an Indian scholar-monk famed for his integration of Yogācāra ideas into Madhyamaka philosophy.
} 
demonstrate that consciousness also fails to exist by intrinsic nature and, thus, exists only conventionally rather than ultimately. ${ }^{253}$ In addition, Xiong's view that all theories of consciousness are limited to a theoretical ambit resembles Svātantrika Madhyamaka, a faction of Madhyamaka that follows Bhāviveka's thought. For the Svātantrika, there can be substantial theories of conventional truth, which can deviate from an intuitive or common-sense understanding of the world, without admitting that the theoretical entities it postulates exist at the level of ultimate truth. ${ }^{254}$ Although Xiong may not necessarily have followed the Madhyamaka views intentionally, his perspective shares similarities with them.

\section{$\underline{\text { 2.1.4 Suchness }}$}

As demonstrated at the beginning of this chapter, in his 1923 Weishixue gailun, Xiong associated the concept of consciousness with the concept of suchness, and considered the two to constitute the first level of his ti-yong system. Although he did not write at length about the concept of suchness, he did explicitly identify it as the Reality of the universe. First of all, when explaining his belief that suchness is not separate from consciousness - one of the meanings of "nothing but consciousness", Xiong stated:

識此言識者, 亦攝色等相分、四分合名一識。如復別說。之實性, 性者體也。字曰真如, 說真如不離識。《三十論》二: 不同餘宗離色心等有實常法名曰真如云云。餘宗謂化地 部。參考《述記》卷十一。 255

The true nature "Nature" means reality. of consciousness "Consciousness" here also includes the image part, such as forms (rūpa), etc. The four parts are together named "consciousness", as I explain further elsewhere. is literally called

\footnotetext{
253 See Jay L. Garfield and Jan Westerhoff, "Introduction: Madhyamaka and Yogācāra: Allies or Rivals?", in Madhyamaka and Yogācāra: Allies or Rivals?, eds. Jay L. Garfield and Jan Westerhoff, New York: Oxford University Press, 2015, pp. 6-9; James Blumenthal, "Two Topics Concerning Consciousness in Śāntarakşita's Yogācāra-Madhyamaka Syncretism”, ibid., pp. 242-251.

254 See Garfield and Westerhoff, "Introduction: Madhyamaka and Yogācāra: Allies or Rivals?", p. 9.

255 Xiong, Weishixue gailun (1923), p. 49.
} 
"suchness". [Thus,] it is said that suchness is not separate from consciousness. The second verse of Triṃsikā says: "[Yogācāra] is not like other schools, [which claim] that separate from material and mental dharmas etc., there exists a real, permanent dharma that is called 'suchness". 256 And so forth. "Other schools" refers to the Mahīsāsaka school. ${ }^{257}$ Consult the eleventh volume of Cheng weishi lun shuji.

As Xiong explained in the auto-commentary, "nature" (xing 性) means "reality" ( $t i$ 體). Therefore, for Xiong, the true nature (shixing 實性) of consciousness is precisely its Reality (shiti 實體). ${ }^{258}$ Since the realm of consciousness is equivalent to the phenomenal world in Xiong's thought, suchness, as the true nature of consciousness, refers indeed to the Reality of the entire phenomenal realm.

In addition to his understanding of suchness and consciousness as having a ti-yong relationship, Xiong also stated that the unconditioned (wuwei 無爲) had real function (shi yong 實用) because it was the Reality (shiti 實體) of all dharmas. ${ }^{259}$ Here, "the unconditioned" is equivalent to suchness, since, in addition to his statement that it is the Reality of all dharmas, Xiong followed Yogācāra philosophy in referring to suchness as an "unconditioned dharma" in his 1923 work. ${ }^{260}$ Xiong compared suchness' "having real function" to material dharmas'

256 This sentence is actually from the Cheng weishi lun. See Xuanzang, Cheng weishi lun, vol. 2, $0006 \mathrm{~b} 15$.

257 The Mahissāsaka school was one of the Hīnayāna schools.

258 In addition, in his Fojia mingxiang tongshi 佛家名相通釋 (Complete explanation of Buddhist terms), a work whose composition began perhaps in the early 1920s but which was published in 1937, Xiong identified the term shixing 實性 in Buddhist texts with the terms benti 本體, shiti 實 體 or the $t i$ 體 in the ti-yong 體用 polarity in Oriental metaphysics (dongfang xuanxue 東方玄學). He believed that all of these terms refer to the absolute truth (jueduide zhenli 絕對的真理). See Xiong, Fojia mingxiang tongshi, p. 370. Indeed, in his writings, Xiong somethimes also used the term shiti 實體, which can be translated literally as "true Reality", as an alternative name for Reality. For clarity, I simply translate shiti in this sense as "Reality" in this thesis.

259 The original Chinese reads: “[無爲] 有實用, 是諸法實體故。”Xiong, Weishixue gailun (1923), p. 238.

260 See, for example, ibid., p. 50. Also, in his Fojia mingxiang tongshi, Xiong said that the Reality of all dharmas, that is, the so-called "suchness", was also called "unconditioned dharma". When dealing 
having the function of offering resistance. ${ }^{261}$ What he tried to argue is that even though suchness is unconditioned, it can still have an effect on the conditioned.

Xiong's perspective that the unconditioned, or suchness, has its real function such that it can have an effect on the conditioned is inconsistent with the Yogācāra understanding of the unconditioned/suchness. As Wu Rujun explains, the term "suchness" (zhenru 真如) is the translation of the Sanskrit word tathatā, which can be explained as “the nature of things as they really are" (ru xing 如性 or rushi xing 如實性). Generally, it can be understood as “truth” (zhenli 真理), although different Buddhist schools have different understandings of what suchness is. For the Yogācāra school, ${ }^{262}$ suchness refers to the fact that all things in the phenomenal world are produced by consciousness and devoid of self-nature. ${ }^{263}$ According to Alan Sponberg, there are two kinds of basic understanding of suchness in Yogācāra philosophy: (1) suchness is the realm when the dependent nature of existence is properly seen (this understanding is consistent with what Wu Rujun mentions); (2) suchness is the underlying ground of all beings that can be reached only by rejecting and transcending both the imaginary and dependent natures of existence. ${ }^{264}$ Most of all, neither of the understandings indicates that suchness can have effects on the conditioned.

Yet in Chinese philosophy, Reality is usually taken to refer to something as the foundation on which the phenomenal world is able to be generated. For example, as we saw in the previous chapter, in the Dasheng qi xin lun, suchness - a supposedly

with the term "unconditioned dharma", Xiong further elucidates the point that "suchness" and the "unconditioned dharma" refer to the same thing. See Xiong, Fojia mingxiang tongshi, pp. 354, 430432.

261 The original Chinese reads: “有實用, 如色即礙用” (Having real function is similar to material dharmas' [having] the function of offering resistance). Xiong, Weishixue gailun (1923), p. 238.

262 The "Yogācāra school" here should refer to the Dharmapāla-Xuanzang tradition of Yogācāra.

263 See Wu Rujun, Weishi xianxiangxue, pp. 212-213, 237-238.

${ }^{264}$ See Alan Sponberg, "The Trisvabhāva Doctrine in India \& China: A Study of Three Exegetical Models", Bulletin of Institute of Buddhist Cultural Studies, Ryukoku University, Kyoto, 1983, no. 21, pp. 100-102. 
unconditioned dharma - is able to cause conditioned dharmas to be generated. In Cheng Yi's and Zhu Xi's philosophy, "principle" (Reality) is conceived as that which manifests itself as phenomena. This understanding of Reality is different from that of suchness in Yogācāra philosophy. It seems that Xiong's tendency to regard suchness as something that has an effect on the conditioned was a result of his being influenced by Chinese philosophical thought.

In his 1923 work, Xiong did not specifically expound the characteristic of suchness, though, as the following quotation shows, he did refer to it as “unchanging” (bubian 不變). When explaining the essential meaning of "consciousness" (as a general name for all eight consciousnesses), he referred to Vasubandhu's Triṃśikā:

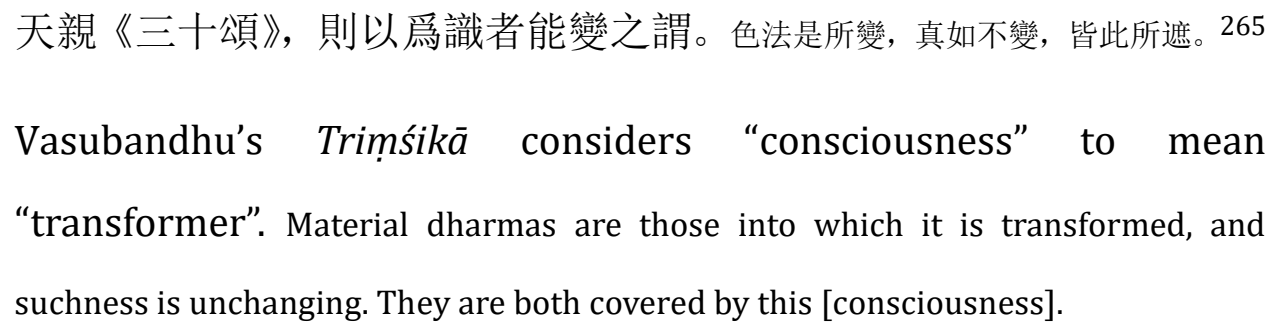

We can see from the supplementary explanation in the auto-commentary that Xiong considered suchness to be that which does not change. This is consistent with his identification of it as an unconditioned dharma, which is constant, neither arising nor ceasing, and free of any condition.

\subsubsection{The Relationship between Suchness and Consciousness}

There are few discussions in Xiong's 1923 work on the relationship between suchness and consciousness - only two statements deal directly with this issue. Therefore, what follows focuses on these two statements, using each to analyse Xiong's views on this issue in the early 1920s.

First, Xiong believed that suchness/Reality/the unchanging and

265 Xiong, Weishixue gailun (1923), p. 51. 
consciousness/Function/transformer (nengbian 能變) were said to show the two aspects of the same thing, with the latter being dependent on the former for its transformation:

詮實性曰不變, 性者體也。顯大用曰能變。能變依於不變, 而有其變。266

The "unchanging" is said to explain the true nature, Nature means Reality. and the "transformer" is said to reveal the great Function. Transformer has its transformation in dependence on the unchanging.

This statement follows Xiong's explanation of Vasubandhu's view of consciousness as "transformer", and the terms "unchanging" and "transformer" clearly refer to those in the preceding quotation and thus to suchness and consciousness, respectively. The first part of the statement shows that suchness and consciousness are two sides of the same coin. Suchness represents the side of constancy, and consciousness represents the side of transformation. The side of constancy is Reality, and the side of transformation is Function. The latter part of the statement reveals Xiong's belief that the unchanging (suchness/Reality) is the foundation, depending on which its Function of transformation can be achieved (here, "transformation", according to the context, refers to the transformation of consciousness into the phenomenal world).

Although Xiong maintained that the transformer depends on the unchanging to generate its transformation, he did not elaborate on how this occurs. That is to say, since suchness is an unconditioned dharma that cannot have any activity, how can it take the role as the foundation on which consciousness transforms into the phenomenal world? In fact, it is difficult to answer this question by referring to Yogācāra theories. As said before, suchness in Yogācāra philosophy has no effect on the conditioned. Thus, although suchness is the Reality of the phenomenal world, it does not have any relation with how phenomena are generated. It is not reasonable, then, to take suchness as the basis for the realisation of the transformation of

266 Ibid., p. 53. 
consciousness. There is a possibility that Xiong's words that "transformer has its transformation in dependence on the unchanging", which seem gratuitous and which lack a clear context, do not stem from Yogācāra. ${ }^{267}$

Indeed, there are certain ideas in Chinese Buddhism that are similar to Xiong's view. For example, the Dasheng qi xin lun presents:
心生滅者，依如來藏故有生滅心。所謂不生不滅與生滅和合，非一非 異, 名爲阿黎耶識。268

As for the mind as arising and ceasing, because it depends on the store of the tathāgata there exists the mind that arises and ceases. That is to say, neither arising nor ceasing and arising and ceasing integrate, and they are neither the same nor different. This is called ālayavijñāna.

In the Dasheng qi xin lun, introduced in the previous chapter, the mind of sentient beings is presented as having two aspects: a suchness aspect, and an arising and ceasing aspect. The former refers to the inherent nature of the mind and the latter to a manifestation of the mind, which gives rise to the phenomenal world. "The mind that arises and ceases" refers to the arising and ceasing aspect of the mind of sentient beings. “The store of the tathāgata” (rulaizang 如來藏; tathāgatagarbha) refers to the luminous intrinsic nature of the mind (zixing qingjing xin 自性清淨心; prakrtipariśuddhacitta) of sentient beings, which is to say, suchness. ${ }^{269}$ In this quotation, the mind that arises and ceases exists in dependence on the store of the tathāgata. In other words, suchness is the basis on which phenomenal activities are

\footnotetext{
267 The Buddhist monk and scholar Juzan 巨贊 (1908-1984) also pointed out that, although Xiong's view indeed originates in Buddhist texts, it is not a perspective of the Yogācāra school. Juzan 巨贊, “Ping Xiong Shili suozhu shu” 評熊十力所著書 (Comments on Xiong Shili's books), in Xiong Shili quanji, supplementary volume A, p. 340. However, Juzan did not explain from which school Xiong's idea derived.

268 Gao, Dasheng qi xin lun jiaoshi, p. 25.

269 See Gao Zhennong's 高振農 explanation of rulaizang 如來藏 in ibid., p. 25, note 1. Elsewhere, the Dasheng qi xin lun further identifies "the store of the tathāgata" with suchness. See, for example, ibid., pp, 101, 125.
} 
generated. This indeed is similar to Xiong's view. Also, the inherent nature of the mind, namely, suchness, is named “the unchanging” (bubian 不變) in the Dasheng qi xin lun. 270 Xiong's reference to suchness as "the unchanging" appears to echo it. Such parallels raise the possibility of a connection between Xiong and the Dasheng qi xin lun.

Nevertheless, the Dasheng qi xin lun presents not only the idea of suchness as the basis for the generation of the mind that arises and ceases (phenomenal activities) but also manages to explain how this happens. In the first place, both the mind of suchness and the mind that arises and ceases are subsumed within the mind of sentient beings (the One Mind) as the two kinds of manifestation of this mind. This provides these two aspects with a common ground. In the second place, as presented in the Dasheng qi xin lun, the mind that arises and ceases is generated as a result of the disturbance of the luminous intrinsic nature of the mind of sentient beings by ignorance (wuming 無明). ${ }^{271}$ This shows that the mind that arises and ceases is a manifestation of suchness and explains why the latter is the basis for the existence of the former. However, although suchness or tathāgatagarbha adapts to the phenomenal conditions of arising and ceasing (zhenru sui yuan 真如隨緣), its intrinsic nature does not change. If ignorance is extinguished, then the mind that arises and ceases will also be extinguished. ${ }^{272}$ This is why it is said that the "neither arising nor ceasing" and the "arising and ceasing" are neither the same nor different. Although Xiong did not explain his view in this way, it is possible that he consulted the Dasheng qi xin lun for his understanding of Reality and Function.

Xiong's other understanding of the relationship between suchness/Reality and consciousness/Function is that the former can be revealed through the latter. As an expression for his claim that suchness, as the true nature of consciousness, is

\footnotetext{
270 See ibid., p, 61.

271 See the relevant text of the Dasheng qi xin lun and also Gao Zhennong's corresponding annotations in ibid., pp. 36-39.

272 Ibid. On this point, see also Makeham, "Xiong Shili's Critique of Yogācāra Thought in the Context of His Constructive Philosophy”, p. 273.
} 
not separate from consciousness, Xiong stated in an auto-commentary that:

不異故不離, 謂即用顯體。273

[Suchness and consciousness] are not different, and so they are not separate. This means that Reality is revealed through Function.

In Xiong's view, because suchness is the true nature of consciousness, the two are not different, and, being not different, they are not separate. In this sense, Reality (suchness) can be revealed through Function (consciousness).

Nevertheless, it should be noted that the "revelation of Reality through Function" (ji yong xian ti 即用顯體) that Xiong identifies here does not mean that Reality manifests itself as Function so that it can be recognised by way of Function. As we have seen, although suchness is the Reality of consciousness, or the phenomenal world into which consciousness transforms, it is not able to manifest itself as consciousness or the various phenomena because it is an unconditioned dharma. Indeed, according to Xiong's view that consciousness is provisionally established to prove that nothing is real, the "revelation of Reality through Function" should mean that Reality (suchness) can be revealed after having refuted the claim that phenomena have self-nature through the provisional establishment of consciousness, and even after having refuted the belief that consciousness truly exists. In this sense, to use Function (consciousness or phenomena) to reveal Reality (suchness) is an apophatic (zhequan 遮詮) rather than a kataphatic (biaoquan 表詮) mode of explanation. ${ }^{274}$

This view of the relationship between suchness/Reality and consciousness/Function is likely to have been an incorporation of the Madhyamaka

\footnotetext{
273 Xiong, Weishixue gailun (1923), p. 49.

274 The "kataphatic mode of explanation" is the kind of statement that, when explaining something, shows directly what that thing is like. The "apophatic mode of explanation", in contrast, is an indirect way of revealing the truth by showing what that thing is not like. See Guo Qiyong, "Lun Xiong Shili de 'jinglun' yu 'lianglun”” 論熊十力的 “境論” 與 “量論” (A discussion of Xiong Shili's ontology and epistemology), in Xiong Shili quanji, supplementary volume B, pp. 1147-1148.
} 
perspective on the relationship between ultimate and conventional truths. Peter N. Gregory, drawing on the scholarship of Nagao Gadjin 長尾雅人 (1907-2005), points out that the two main traditions of Indian Mahāyāna take different stands on this issue. The Madhyamaka tradition, particularly the Prāsangika tradition, ${ }^{275}$ assumes that there is an absolute disjunction between ultimate and conventional truths, that the latter conceals the former and that it is associated with the realm of falsehood and delusion. Thus, to reveal ultimate truth, conventional truth must ultimately be rejected. On the other hand, the Yogācāra tradition of Sthiramati (as well as the Svātantrika tradition within Madhyamaka) assumes that there is a necessary continuum leading from conventional truth to ultimate truth, that the former manifests the latter and that it is associated with the realm of ultimate truth. Thus, conventional truth can be used as the necessary bridge by which ultimate truth can be reached. ${ }^{276}$ Xiong's view is consistent with the Madhyamaka perspective, so his understanding of the idea of "revealing Reality through Function" indicates, again, a departure from Yogācāra.

In fact, the theory of "three natures" in Yogācāra shows the connection between suchness and consciousness/phenomena. This theory, as Wu Rujun points out, takes the second nature as its central point. This nature refers to the state that everything is generated depending on causes and conditions. If one takes things to be real and as having self-nature but cannot realise their true nature - they arise from causes and conditions and thus are empty (the second nature) - then the state produced by this mistaken realisation is the first nature. If the fact that things are dependently arisen and thus empty is understood correctly, then this state of consciousness is the third nature, the "nature of existence being perfectly accomplished", which is precisely the suchness. Accordingly, the first and the third nature are actually two ways of understanding the second nature by our

\footnotetext{
275 Prāsangika is a faction of Madhyamaka that follows the thought of Candrakīrti (Yuecheng 月稱, sixth-seventh century), an influential Madhyamaka scholar in India.

276 Gregory, Tsung-mi and the Sinification of Buddhism, pp. 103-104.
} 
consciousness. ${ }^{277}$

Thus, as John Powers illustrates, in Yogācāra philosophy suchness or ultimate truth cannot be separated ontologically from phenomena and is inherent in phenomena 278 - it is consciousness that differentiates them. ${ }^{279}$ Yet when consciousness realises the true nature of things from delusive phenomena, it is not different from suchness in this state. In Yogācāra Buddhism, this state of consciousness can be achieved through the epistemological idea of "the transformation of consciousness into wisdom (jñāna)" (zhuan shi cheng zhi 轉識 成智). ${ }^{280}$

Although Xiong stated that suchness was the true nature/Reality of consciousness and so not separate from consciousness, he did not expound this view in his 1923 work. As we have seen, he did not expound the theory of "three natures" at all. Nor did he expound on the idea of "the transformation of consciousness into wisdom", except for occasionally mentioning some related ideas. ${ }^{281}$ Since the two theories are not in Xiong's 1923 work, which means that

277 Wu Rujun, Weishi xianxiangxue, pp. 176-178; “Weishizong zhuan shi cheng zhi lilun zhi yanjiu”, pp. 118-124. According to Alan Sponberg, this understanding of the three natures, that is, to put the second nature in the axial position, is based on the primary presentation of the three natures in the Mahāyānasamgraha-śästra. Nevertheless, there appeared a different model of the interpretation of the three-nature doctrine subsequently in East Asia, which presents the three natures as three levels, each revealing a progressively deeper degree of reality. See the two basic models of the interpretation of the three-nature doctrine in Sponberg, "The Trisvabhāva Doctrine in India \& China", pp. 99-103. For other discussions on the relationship between the three natures, see, for example, Yao, "Yogācāra Critiques of the Two Truths", p. 327; Lusthaus, "Yogācāra School", p. 918; Powers, "Yogācāra: Indian Buddhist Origins", p. 52.

278 It should be noted that this still says that suchness/ultimate truth, which is concealed by phenomenal appearances, is the true nature of phenomena, rather than that it is no different from phenomena.

279 Ibid., p. 45.

280 For a discussion of "the transformation of consciousness into wisdom", see, for example, Epstein, "The Transformation of Consciousness into Wisdom in the Chinese Consciousness-only School According to the Cheng Wei-shi Lun"; Wu Rujun, "Weishizong zhuan shi cheng zhi lilun zhi yanjiu", pp. 98-208.

${ }^{281}$ For example, Xiong referred to suchness as the ālambana condition for fundamental wisdom (genben zhi 根本智) and post-enlightened wisdom (houde zhi 後得智). See Xiong, Weishixue gailun 
there is no proof that he considered suchness and consciousness to have a connection, and since he believed that suchness was revealed after consciousness has been dispatched, there seems to be a tendency to separate suchness and consciousness from each other in this early work. Moreover, the absence of the theories makes Xiong's thought appear, at this time, to be a somewhat simplistic understanding of Yogācāra - although the omission might have been deliberate for the purpose of making his own views of suchness and consciousness consistent.

Till now, we have examined Xiong's views of suchness as Reality and consciousness as Function as presented in his 1923 Weishixue gailun. As demonstrated at the beginning of this chapter, consciousness and suchness constitute only the first level of Xiong's two-level ti-yong system. Within the realm of Function/consciousness, there is another pair of Reality and Function productive power and manifest activity, which constitute the second level of his $t i$ yong system. The following section will focus on this second level and discuss how Xiong understood productive power as Reality and manifest activity as Function.

\subsection{Level 2: Productive Power as Reality and Manifest Activity as Function}

\subsubsection{Productive Power}

At the time Xiong conceived suchness as Reality, he also presented another Reality - productive power. Unlike suchness, which Xiong presented as the true nature of dharmas, he presented the concept of productive power as the cause of dharmas. According to Xiong, productive power got its name because of its ability to generate those dharmas in the phenomenal world as a great power (da shili 大勢力). It is sometimes called "seeds" (zhongzi 種子; bïja), which conveys the sense of manifestation (xian 現). ${ }^{282}$

Unlike suchness, which is unchanging, productive power possesses the

(1923), pp. 104, 152.

282 Ibid., pp. 69-70. 
characteristic of arising and ceasing:

謂此功能自體, 纔生無間即滅, 非生己可容暫住。……刹那滅者, 非滅 已即衒。由此功能自性, 前滅後生, 刹那刹那連言之者, 顯其相續, 便是長時。 相似隨轉。轉者生起義。283

That is to say, productive power itself ceases as soon as it arises without any interval, and it is not that after it has arisen, it is able to abide temporarily. ... As for the "instantaneously ceasing", it is not that after [productive power itself] has ceased it is then interrupted. This is because, as for the intrinsic nature of productive power, when the former ceases the latter arises, and instant by instant That [the "instant"] is said repeatedly is to show the continuity of [the ceasing and arising of the intrinsic nature of productive power], which, then, indicates a constant situation. a similar one arises (zhuan 轉) immediately [following the ceasing of the preceding one]. Zhuan 轉 means to arise (shengqi 生起).

Here Xiong maintains that productive power instantaneously arises and instantaneously ceases without any moment of temporary abiding. Yet, as soon as one momentary productive power ceases, another with a similar nature arises immediately. In this way, a continuous series of momentary productive powers that possess the same nature forms.

According to Xiong, this characteristic is necessary for productive power to have the ability to generate, as he explains:

由暫住時, 無轉變故, 即是常法, 不可說有能生用也。284

This is because when [productive power itself] abides temporarily, it does not undergo any transformation and so is an unchanging dharma, and cannot be said to have the function of being able to generate.

\footnotetext{
283 Ibid., p. 71.

284 Ibid.
} 
功能非斷、非常, 宛爾生滅, 前念種滅, 後念種生, 幻有遷流, 乃云宛爾。成其 勝用。體是生滅, 故有能生勝用, 若是常住法者, 即非能生。285

Productive power is neither interrupted nor permanent, but seems to arise and cease, When the seed in the preceding thought-moment ceases, the seed in the succeeding thought-moment arises, giving the illusion of shifting and flowing. Therefore, it is said that [productive power] seems [to arise and cease]. which makes its excellent function possible. The reality [of productive power] is arising and ceasing, and so it has the excellent function of generating. If it is an unchanging dharma, then it is not a generator.

Both statements show that an unchanging dharma is unable to assume the role of generator. Thus, only if productive power is always transforming - that is, arising and ceasing - can it generate dharmas. It seems that Xiong realised that suchness in Yogācāra philosophy is an unconditioned dharma unable to generate conditioned dharmas. He therefore presented productive power as a different kind of Reality for the purpose of explaining how conditioned dharmas appear.

For Xiong, productive power exists only at the level of conventional truth. He maintained that, in respect to productive power, we should differentiate the two kinds of truth:

然此功能, 約二諦分別: 唯依世俗, 可名實有; 推入勝義, 即是虛幺 假法。286

Nevertheless, as for productive power, there is customarily a differentiation between the two truths: it can be said to be real only according to conventional truth; if it enters the purview of ultimate truth, then it is indeed an illusory, provisional dharma.

Furthermore, according to Xiong, productive power is stored in the eighth or store

\footnotetext{
285 Ibid., pp. 96-97.

286 Ibid., p. 72.
} 
consciousness (ālayavijñanna) as the image part of this consciousness, and so it is not separate from consciousness. ${ }^{287}$ Both this view and the view in the above quotation reveal why, as expressed in the statement quoted at the beginning of this chapter, Xiong considered productive power to be the Reality within Function (用 [中]之體) and the ti-yong conceptual polarity constituted by productive power and manifest activity to be included within Function (用中復分體用). That is to say, since productive power can be considered real only at the level of conventional truth, it can be posited only as Reality within the realm of the phenomenal world or consciousness (Function). What is more, since productive power is a part of consciousness, it is, again, shown to be included within Function (consciousness).

Furthermore, since productive power is a part of consciousness and belongs to the phenomenal realm, then, from the perspective of ultimate truth, it is actually Function. In other words, since consciousness/the phenomenal realm is the Function of suchness, productive power, as the "Reality within Function", should also be the Function of suchness theoretically. Xiong did not discuss the relationship between suchness and productive power directly in his 1923 Weishixue gailun. Yet, there is a passage in this work that reveals his view that suchness is Reality and productive power is Function:

生義是用義, 大用流行，充塞法界，法界是體，用依於體，而遍全體，無有虧欠。 神變無方，烏容思議。288

The meaning of generation pertains to the meaning of Function. Great Function flows and moves, and it fills the dharma-realm (dharmadhātu). The dharma-realm is Reality. Function depends on Reality and permeates its entirety, and there is nothing Function does not fill. Since god-like transformation lacks spatial extension, how can it be conceptualised?

This statement is presented in the context that Xiong was emphasising the

\footnotetext{
287 Ibid., pp. 53, 70, 72.

288 Ibid., p. 89.
} 
continuous generation of seeds, or productive power. Thus, the "generation" (sheng 生) in this statement refers to that of seeds/productive power. The "dharma-realm" (fajie 法界) in this statement should refer to suchness, as Xiong in his Fojia mingxiang tongshi 佛家名相通釋 (Complete explanation of Buddhist terms) explicitly said that the unconditioned dharma, that is, suchness, the Reality of the myriad dharmas, was also called “dharma-realm" (fajie 法界). ${ }^{289}$ From Xiong's claim that the generation of seeds/productive power pertains to Function and that the dharma-realm is its Reality, we can infer that suchness and seeds/productive power constitute a pair of Reality and Function. Also, from the above quotation, we can see that Xiong believed that the continuous generation of seeds/productive power (Function), by depending on suchness (Reality), fills the realm of Reality, or suchness. This seems to be consistent with his claim that "transformer has its transformation in dependence on the unchanging", discussed earlier in this chapter. However, Xiong did not further explain his view of Reality and Function presented in the above quotation.

\subsubsection{Manifest Activity}

Although there is an indication in Xiong's 1923 Weishixue gailun that productive power is the Function of suchness, Xiong considered it also to be the Reality of manifest activity. In his 1923 work, Xiong specified that "manifest activity" was an alternative name for consciousness. ${ }^{290}$ Indeed, he sometimes used the terms “manifestly activated consciousness" (xianxing shi 現行識) and “manifest consciousness" (xian shi 現識) interchangeably, both having the same meaning as "manifest activity".291 Xiong also used the term "manifest activity" to refer to the material and mental dharmas into which consciousness transforms. In this regard, he sometimes used such terms as "manifestly activated material and mental dharmas” (xianxing se xin fa 現行色心法), “material dharmas as manifest activity”

\footnotetext{
289 Xiong, Fojia mingxiang tongshi, p. 431.

290 Xiong, Weishixue gailun (1923), p. 50.

291 See, for example, ibid., pp. 70, 98.
} 
(sefa xianxing 色法現行 or se xian 色現 for short), and “mental dharmas as manifest activity" (xinfa xianxing 心法現行 or xin xian 心現 for short) to substitute for "manifest activity" in his 1923 work. $^{292}$

As Makeham explains, manifest activity refers to the appearance of things in their manifest aspect in the seven consciousnesses as they emerge from seeds in the eighth consciousness. ${ }^{293}$ In other words, things can be divided into two aspects, the manifest and the latent. The manifest aspect refers to those dharmas into which the first seven consciousnesses transform; the latent aspect is their seeds stored in the eighth consciousness as their origins. In this regard, manifest activity is actually the manifest form of seeds, and it is named vis-à-vis seeds, the latent form. ${ }^{294}$ In what follows, we will see how Xiong interpreted the relationship between productive power/seeds as Reality and manifest activity as Function.

\subsubsection{The Relationship between Productive Power and Manifest Activity}

According to Xiong, productive power can give rise to manifest activity with the help of other conditions. ${ }^{295}$ Yet this does not mean that productive power and manifest activity are distinct things, independent of each other. Rather, from Xiong's perspective, the two are non-dual:

一切現行色心法, 俱由各自功能轉變, 宛爾幻有。若離各自功能, 無 別自相。故功能者, 推顯至隱而言之也。296

Every manifestly activated material or mental dharma illusively appears due to the transformation of its own productive power. It does not have any other intrinsic attribute (sva-lakșaṇa) without its

\footnotetext{
292 Ibid., pp. 70, 72, 98.

293 Makeham, "Xiong Shili's Critique of Yogācāra Thought in the Context of His Constructive Philosophy", p. 254, note 41.

294 For a discussion of seeds and manifest activity, see Wu Rujun, "Weishizong zhuan shi cheng zhi lilun zhi yanjiu", p. 101.

295 See, for example, Xiong, Weishixue gailun (1923), p. 97

296 Ibid., p. 70.
} 
productive power. Thus, productive power is spoken of as the latent deduced from the manifest.

According to this statement, each manifestly activated dharma is that into which its productive power transforms. The latter is the origin and the intrinsic nature of the former, and the former is the illusory appearance of the latter. The expression that "productive power is spoken of as the latent deduced from the manifest" indicates that a manifestly activated dharma is the manifest, and its productive power is the latent. Accordingly, the two refer to the same thing and are non-dual, although expressed from different aspects.

Since Xiong held that productive power and its manifest activity were two aspects of the same thing, on the issue of the generation of the manifest activity by its productive power, it is certainly not the case that the former arises after the latter has ceased but, rather, that the two arise and cease simultaneously. Although Xiong considered the two to be causally related (productive power was established as the cause for the generation of dharmas), he did not mean by this that they have a sequence. In accord with the Yogācāra principle of "the simultaneity of cause with its effect" (guo juyou 果俱有), ${ }^{297}$ one of the six characteristics of productive power in Yogācāra philosophy, ${ }^{298}$ he clearly expressed the view that productive power and its manifest activity arise and cease interdependently and simultaneously:

雖刹那滅，然非己滅乃生其果。由此功能殊勝，正轉變位，能取與果。 能為因義, 名為取果。若果起時, 因付於果, 名為與果。言正轉位者, 簡異過、未, 轉已名 過去，未轉名未來。即種因也。生現，果也。因果同時，相依俱有，不同經部

\footnotetext{
297 According to Tao Jiang, the view that the cause and the effect have to be simultaneous is unique to the Dharmapāla/Xuanzang system of Yogācāra, but it is not necessarily accepted by other Yogācārins. See Tao Jiang, Contexts and Dialogue, p. 62.

298 In Yogācāra philosophy, productive power has six characteristics: it instantly ceases (cha'na mie 刹那滅); it is simultaneous with its effect (guo juyou 果俱有); it continuously arises by following the preceding seed of the same kind (heng suizhuan 恆隨轉); it belongs to a definite moral category (xing jueding 性決定); it depends on a multitude of conditions (dai zhongyuan 待眾緣); and it produces its own effect (yin ziguo 引自果). See Xuanzang, Cheng weishi lun, vol. 2, 0008c07.
} 
前法望後法爲因。299

Although [productive power itself] ceases instantly, it is not only after it has ceased that it then generates its effect. Because this productive power dominates and is precisely at the point of transformation it is able to obtain and grant its effect. "Productive power" means cause, and so it is said to [be able to] obtain effect. When the effect arises, the cause is turned over to it, which is called "to grant effect". To say "precisely at the point of transformation" is to distinguish [productive power's position] from past and future. Having already transformed is said to be past; having yet to transform is said to be future. That is to say, as for the generation of manifest activity That is, effect. by its seed, That is, cause. the cause and the effect are simultaneous, existing interdependently. This is different from the Sautrāntika school, 300 which holds that the preceding dharma is the cause with regard to the succeeding dharma.

Although Xiong considered productive power and its manifest activity to have a causal relationship, he did not consider either to be first or second in sequence. This contradicts a conventional understanding of causality, which assumes that the cause precedes its effect. Xiong therefore had to provide a reasonable explanation for his argument. His statement that productive power is exactly at the point of transformation and, thus, can obtain and grant its effect, is an attempt to provide such an explanation. Further in the auto-commentary, he maintained that the position of productive power is neither past nor future; it is present. And yet, as an explanation this remains unclear.

Xuanzang did, however, provide a clearer explanation of this issue: if the cause precedes its effect, then when its effect comes into existence, the cause will have gone. By the same token, if the effect succeeds its cause, then when its cause

\footnotetext{
299 Xiong, Weishixue gailun (1923), p. 71.

300 The Sautrāntika school was one of the Hīnayāna schools in India.
} 
is engaged in the causal activity, the effect has not yet emerged. If this were the case, then in what sense can we claim that the cause causes the effect since the cause and the causal activity belong to the past and hence no longer exist? ${ }^{301}$ This explains why productive power must lie "precisely at the point of transformation": only in this way will it be able to "obtain and grant its effect". Given this sense of cause and effect, as Tao Jiang points out, Xuanzang actually transformed causality - as understood in the conventional sense - into grounding. That is, the simultaneity of cause and effect renders the former the ground for the latter. ${ }^{302}$

Xuanzang's case applies equally to Xiong Shili. By supporting the idea of "the simultaneity of cause with its effect", Xiong, of course, also transformed causality into grounding. This is consistent with his view that productive power is the intrinsic nature of its manifestly activated dharma into which it transforms, and, based on its transformation, the manifestly activated dharma can appear, albeit as illusion. On the relation between productive power and manifest activity, Tao Jiang cites the Japanese Buddhist scholar Seibun Fukaura's 深浦正文 (1889-1968) metaphor, which is helpful for us to understand Xiong's perspective: the generation of a dharma by its productive power is similar to the casting of a shadow by an object. Just like the causal relationship between the object and its shadow and their simultaneous existence, productive power and its manifestly activated dharma also coexist simultaneously despite the causal relationship between the two. ${ }^{303}$ Therefore, in Xiong's 1923 work, the presentation of productive power and manifest activity as cause and effect does not contradict his perspective that the two exist simultaneously, respectively as the intrinsic nature and the external manifestation.

Despite the inseparability of productive power and manifest activity, Xiong

\footnotetext{
301 See Tao Jiang, Contexts and Dialogue, p. 62.

302 Ibid., p. 63.

303 Ibid., p. 72. In fact, as Makeham suggested to me, this metaphor is not perfect: we can have an object appearing without a shadow, and so the co-existence of the two is broken.
} 
also emphasised the difference between the two:

現行是用, 功能是體。體用固不離, 而實不即。如心現行。能緣慮, 心 種不爾; 色現行。有質礙, 色謂第八識等實根塵相分。色種不爾。參考《述記》十 四第三葉。304

Manifest activity is Function, and productive power is Reality. Although Reality and Function are certainly not separate, they are in fact not identical. For example, minds Manifest activity. can be cognitively concerned about [objects], whereas the seeds of minds cannot; forms Manifest activity. offer physical resistance, For the eighth and other consciousnesses, "forms" refers to the image parts of the cognitive objects of the substantial faculties and dusts. whereas the seeds of forms do not. Refer to Cheng weishi lun shuji, volume 14, page 3.

According to Xiong's explanation, the reason that productive power and manifest activity are not identical is that the former does not have actual utility whereas the latter does. However, because manifest activity is only the manifest form of productive power and lacks other intrinsic attributes, its utility must also be possessed by productive power, if only potentially. Therefore, Xiong's statement can be understood as follows: only when productive power is actualised as manifest activity can the potential utility be realised. From this point, productive power can be considered to be the potentiality of manifest activity, and manifest activity can be considered to be the actualisation of productive power. Thus, this statement reveals Xiong's understanding of productive power and manifest activity as nondual from a different angle, in addition to being the latent and the manifest.

The relationship between productive power and manifest activity as "potential and actual", as well as "intrinsic nature and external manifestation", is also reflected in Xiong's elucidation of the consistency of their attributes. Following

304 Xiong, Weishixue gailun (1923), p. 97. 
the preceding quotation, Xiong continues:

然復當知, 體用定相隨順, 如色種不生緣慮用, 心種不生質礙用。故所生現, 望能生種, 亦 說名自類。……種望現是因緣性, 即體謂種。用謂現。決定相似。如心種定 生心法現行，不生色現；色種定生色法現行，不生心現。305

However, it should further be known that Reality and Function must be consistent with each other. For instance, a seed of form does not generate a Function of being cognitively concerned about [objects], and a seed of mind does not generate a Function of offering physical resistance. Thus, the manifest activity that is generated is said to be the same kind with regard to the seed as the generator. ... The seed is the cause as condition with regard to the manifest activity. That is, Reality Namely, the seed. and Function Namely, the manifest activity. must be alike. For example, a seed of mind must generate a mental dharma, rather than a material dharma, as its manifest activity; a seed of form must generate a material dharma, rather than a mental dharma, as its manifest activity.

It is precisely because a seed and its manifest activity are the potential and the actual, as well as the intrinsic nature and the external manifestation, that their attributes must be consistent, although the latter manifests it externally and the former does not. Xiong goes on to argue that because the attributes of a seed and its manifestly activated dharma are consistent, given that there are various and numerous manifestly activated dharmas in the phenomenal world, there cannot be only one cause (productive power/seed) that engenders all effects (manifest activity). It follows for him that there must be various types of seed as the origins and Realities of their own manifestly activated dharmas, respectively. ${ }^{306}$ This view endows Xiong's thought with a feature of pluralism.

From what I have demonstrated in this chapter, it seems that, in his 1923

\footnotetext{
305 Ibid., pp. 97-98. As for this point, also see p. 72 in the same book.

306 Ibid., pp. 72, 98.
} 
Weishixue gailun, it is based on the differentiation of the two truths that Xiong divided his ti-yong system into two levels. From the perspective of ultimate truth, suchness is the sole Reality, and consciousness, which represents the phenomenal realm, is its Function. From the perspective of conventional truth, productive power, or seeds, is Reality, and manifest activity is Function. Indeed, both productive power/seeds and manifest activity are included within the realm of consciousness and, thus, productive power is still phenomenal rather than ontological from the perspective of ultimate truth. Nevertheless, although Xiong presented his two-level ti-yong system primarily based on the differentiation of the two truths, there is actually another important factor that he probably drew upon to form his conception of this ti-yong system. This contributing factor is Ouyang Jingwu's perspective of ti-yong, which will be elaborated in the following.

\subsection{The Influence of Ouyang Jingwu's Ti-yong Perspective}

Xiong's teacher Ouyang Jingwu had similarly presented suchness and consciousness as constituting the first level of a ti-yong system, and then presented seeds and manifest activities as constituting another level of this ti-yong system, which is included within the realm of the Function of the first level.

According to the transcript of the lecture series entitled "Weishi jueze tan", given in 1922 by Ouyang at the China Institute of Inner Learning, Ouyang presented a three-layered ti-yong system:

無爲是體, 有爲是用; 此粗言之也。若加細別, 則有體中之體, 體中 之用，用中之體，用中之用。307

The unconditioned is Reality, and the conditioned is Function. This is in broad terms. If we distinguish them finely, then there is the Reality in the Reality, the Function in the Reality, the Reality in the Function, and

\footnotetext{
307 Ouyang, "Ouyang Jingwu xiansheng yanjiang", recorded by Nie Ougeng and edited by Lü Cheng, p. 3.
} 
the Function in the Function.

This actually describes three pairs of Reality-Function: Reality and Function in general, the Reality and Function within Reality, and the Reality and Function within Function.

Ouyang explained the pair of Reality and Function in general - the unconditioned as Reality and the conditioned as Function - in these terms:
無爲法不待造作，無有作用，故爲諸法之體。反之，由造作生，有作 用法, 即是有爲, 故有爲是用。308
The unconditioned dharma does not require creation, and it does not have activity. Thus, it is the Reality of [conditioned] dharmas. On the contrary, dharmas that are created and have activities are the conditioned. Therefore, the conditioned is Function.

By explaining why the unconditioned is Reality and the conditioned is Function, Ouyang maintained that with regard to this pair of Reality and Function, Reality, which for him refers to suchness, ${ }^{309}$ is neither created nor active. By contrast, Function refers to those dharmas that are created and active. Ouyang further talked about this pair of Reality and Function by highlighting their characteristics (xiang 相):

非生滅是體, 生滅是用; 常一是體, 因果轉變是用。310

"Non-arising and non-ceasing" is Reality, and "arising and ceasing" is

Function; the constant is Reality, and causality and transformation are Function.

According to Ouyang's subsequent explanation, "arising and ceasing" refers to our consciousness, which includes numerous thought-moments that are continuously

\footnotetext{
308 Ibid.

309 Ibid.

310 Ibid., p. 4.
} 
arising and ceasing without stopping transitorily. Ouyang further explained that "transformation", as he used it here, means exactly arising and ceasing and that due to causality (here "causality" refers to the generation of phenomena by seeds) and transformation (that is, the arising and ceasing of momentary thoughts), there is the appearance of illusory phenomena. According to Ouyang's one-sentence explanation, that which is opposite to causality and transformation is the "constant". 311 Ouyang's understanding of this pair of Reality and Function obviously accords with Xiong's views of suchness as Reality and consciousness as Function.

For Ouyang, the "Reality in Reality" refers to the one true dharma-realm (yi zhen fajie 一真法界), ${ }^{312}$ and the "Function in Reality" refers to the suchness revealed through eradicating the two attachments to the existence of a real self and the existence of real dharmas (erkong suoxian zhenru 二空所顯真如). ${ }^{313}$ Since this pair of Reality and Function does not appear in Xiong's 1923 work, it will not be discussed here.

The "Reality in Function" and the "Function in Function" refer to seeds and their manifest activities. Ouyang explained this pair like this:

何以謂種子爲用中之體? 以種子眠伏藏識, 一切有爲所依生故。何以 謂現行爲用中之用？以現行有強盛勢用，依種子而起故。314

Why are seeds said to be the Reality in Function? This is because seeds are dormant and concealed in the store consciousness; they are that upon which all conditioned dharmas are generated. Why are manifest activities said to be the Function in Function? This is because manifest

\footnotetext{
311 Ibid.

312 The "one true dharma-realm" is a term used by the Yogācāra and the Huayan schools to mean the ultimate truth (jizhide zhenli 極致的真理). See Wu Rujun, Fojiao sixiang dacidian 佛教思想大 辭典 (Dictionary of Buddhist thought), Taibei: Taiwan shangwu yinshuguan, 1992, p. 15.

313 Ouyang, "Ouyang Jingwu xiansheng yanjiang", recorded by Nie Ougeng and edited by Lü Cheng, pp. 3-4.

314 Ibid., p. 4.
} 
activities have powerful functions, and they arise in dependence on seeds.

To say that seeds are within Function is to say that they are stored in the eighth consciousness; to say that they are Reality is because they are that on which conditioned dharmas are generated. To say manifest activities are the Function of seeds is both because they have powerful functions and also because they depend on seeds to be generated. This is consistent with Xiong's understanding of productive power and manifest activity as Reality and Function.

Now let us recall Xiong's statement quoted at the beginning of this chapter:

不生滅是體, 生滅是用。用中復分體用: 功能是用之體, 現行是用之 用。315

That which neither arises nor ceases is Reality, and that which arises and ceases is Function. Within Function there is a further division into a Reality and a Function: productive power is the Reality within Function, and manifest activity is the Function within Function.

This resembles Ouyang's view. Ouyang did not initiate the perspective that the unconditioned/"non-arising and non-ceasing"/suchness is Reality and the conditioned/"arising and ceasing"/consciousness is Function. 316 Yet, as the contemporary Buddhist scholar Chang Zhengrong 常崢嶸 points out, Ouyang was the first to propound the view that seeds are Reality and manifest activities are Function. ${ }^{317}$ When Ouyang gave his lectures in 1922, Xiong had just finished

\footnotetext{
315 Xiong, Weishixue gailun (1923 nian), p. 129.

316 For example, this perspective already appeared in Zong jing lu 宗鏡錄 (Records of the mirror of axioms), a Buddhist text compiled by the Chan scholar Yongming Yanshou 永明延壽 (904-975). Drawing on the idea of "the two aspects of the mind of sentient beings" presented in the Dasheng q $i$ xin lun, Zong jing lu says: “Suchness is Reality, and arising and ceasing is Function” (真如是體, 生 滅是用). See Yongming Yanshou 永明延壽, Zong jing lu 宗鏡錄 (Records of the mirror of axioms), vol. 57, in the CBETA edition of the Taishō Tripitaka, T48n2016_057, 0742c13.

317 Chang Zhengrong 常崢橴, “Ouyang Jingwu de sanchong sizhong ti yong guan” 歐陽竟無的三重 四種體用觀 (Ouyang Jingwu's three-tier and four-kind ti-yong system), Zongjiaoxue yanjiu 宗教學
} 
studying Yogācāra Buddhism under his supervision, and was composing the 1923 Weishixue gailun. There is, then, the strong possibility that Xiong drew on his teacher's thought for his own understanding of ti-yong at that time.

\section{Concluding Remarks}

In the early 1920s, Xiong presented a two-level ti-yong system in his 1923 Weishixue gailun by differentiating the two truths and almost certainly by drawing on Ouyang Jingwu's understanding of ti-yong. At the level of ultimate truth, he conceived suchness as Reality and consciousness as Function. In Xiong's discussions, suchness is the true nature of consciousness/the phenomenal world; it is constant and not subject to conditions. In contrast, consciousness - representing the phenomenal world - is a continuum of momentary thoughts that arise and cease instantly and are generated by conditions. Thus, consciousness is devoid of self-nature. For Xiong, consciousness was established for the purpose of refuting the views that phenomena are real and that there is nothing but "emptiness", although, in the end, it too should be dispatched because it does not exist either. In this sense, Xiong actually presented a Reality without Function. Consistent with this understanding of Reality and Function, the idea of "revealing Reality through Function", mentioned in Xiong's 1923 work, actually means that Function is not real and, by dispatching it, Reality can be revealed.

Moreover, given that suchness is the true nature of consciousness/phenomena, Xiong considered the two to be not separate from each other. However, since suchness is an unconditioned dharma that cannot cause or be caused by conditioned dharmas, and since consciousness is merely provisionally established, suchness and consciousness exist actually independent of each other. To put it another way, the generation of consciousness has nothing to do with suchness. Also, without consciousness, suchness still exists. Indeed, suchness and

研究, issue 4, 2012, p. 135. 
consciousness are two ways of revealing ultimate truth: the former shows what ultimate truth is (the apophatic mode of explanation), and the latter shows what ultimate truth is not (the kataphatic mode of explanation). Although Xiong said that consciousness has its transformation in dependence on suchness, he did not further explain this view in his 1923 work.

Xiong's perspective, then, outlined above - either it is "a Reality without Function" or "Reality and Function are independent of each other" - runs counter to the primary implication of the ti-yong paradigm in Chinese philosophy. As demonstrated in the previous chapter, in Chinese philosophy, ti and yong as a conceptual polarity stand in relation to each other: $t i$ is the $t i$ of $y o n g$, and yong is the yong of $t i$. The two are usually considered to be a polar whole, inseparable, and therefore non-dualistic. As a result, as Mou Zongsan demonstrated, the ti-yong paradigm in the Chinese philosophical context is unsuitable for Indian Buddhism. ${ }^{318}$ By applying the ti-yong conceptual polarity in Chinese philosophy, Xiong's analysis of Yogācāra theories inevitably led to his doubting the rationality of Yogācāra theories.

At the level of conventional truth, Xiong conceived productive power as Reality and manifest activity as Function. Manifest activity refers to consciousness or the dharmas in which consciousness is manifested. Productive power was established as the cause for manifest activity, possessing the characteristic of arising and ceasing, which is why it can generate manifest activity. Although productive power is the cause and manifest activity the effect, for Xiong they are not separate or distinct. Rather, in Xiong's view, they are two aspects of the same thing: productive power is the intrinsic nature, the latent, and the potential; and manifest activity is the external appearance, the manifest, and the actual. In this sense, the two are non-dual. Because productive power, according to Xiong, can be

\footnotetext{
318 See Mou Zongsan 牟宗三, “Fojia ti yong yi zhi hengding” 佛家體用義之衡定 (A judgment of the meaning of ti-yong in Buddhism), Xinti yu xingti 心體與性體 (Reality of the mind and of human nature), Taibei: Zhengzhong shuju, 1968-1969, vol. 1, pp. 571-577.
} 
considered real only at the level of conventional truth, and because it is actually a part of consciousness, it is still phenomenal rather than ontological from the perspective of ultimate truth. This is why the conceptual polarity of Reality and Function constituted by productive power and manifest activity can be said to exist only from the perspective of conventional truth.

Although suchness and productive power are both presented as the Reality of consciousness/phenomena in Xiong's 1923 work, it seems that they play different roles in his thought. Suchness is the true nature of consciousness/phenomena. This, however, cannot reflect how consciousness/phenomena appears. Thus, productive power was used to explain the generation of consciousness/phenomena. Relative to the "independence" of suchness from consciousness/phenomena, productive power obviously has a close relation with the latter.

Xiong's understanding of ti-yong in his 1923 work is revealed through his interpretations of Yogācāra theories. Yet his views of Reality and Function were expressed not only through his faithful interpretation of Yogācāra learning but also through his deviation from it. Indeed, his differentiation of the two truths (existence versus nonexistence) or the disconnection of them is precisely a perspective to which certain Yogācārins objected. As Zhihua Yao points out, by presenting the theory of "three natures", which expresses a holistic and yet non-dualistic worldview, such Yogācārins as Asañga and Vasubandhu rejected the Madhyamaka paradigm of the two truths that suggests a two-tiered structure into truth and a dualistic tendency towards positing existence versus nonexistence. ${ }^{319}$ However, as shown earlier, Xiong neglected the theory of the three natures, the important Yogācāra theory which he had been fond of earlier. Instead, he adopted the twotruth theory. It needs to be said that this, to some extent, deviated from the Dharmapāla-Xuanzang tradition of Yogācāra.

Further, as Yao shows, the key disagreement between Yogācāra (centring on

319 See Yao, "Yogācāra Critiques of the Two Truths", pp. 327, 332-333. 
the thought of such early Yogācāra masters as Asanga and Vasubandhu) and Madhyamaka is manifested precisely in the conflict between the theory of the three natures and the theory of the two truths. From the Madhyamaka perspective, things are real at the level of conventional truth, yet, at the level of ultimate truth, nothing exists, and all is devoid of intrinsic nature. The Yogācāra school, in contrast, bases itself on the three natures to maintain that the imagined nature of things does not exist while the dependent nature does exist. ${ }^{320}$ Although Xiong developed his twolevel ti-yong system probably by drawing chiefly on Ouyang Jingwu's understanding of Reality and Function, his adoption of the differentiation of the two truths to further illuminate the two levels of ti-yong tended towards Madhyamaka. Most of all, Xiong's deviation from the Dharmapāla-Xuanzang tradition of Yogācāra and absorption of Madhyamaka philosophy indicates his tendency to divide the ontological and the phenomenal into two realms.

Although Xiong had not established his mature philosophical system by the early 1920s, his 1923 Weishixue gailun can be considered as a foundation from which his ti-yong thought was repeatedly modified in later writings. Therefore, only by clarifying Xiong's understanding of Reality and Function at this stage are we in a position to comprehend how he subsequently developed his ti-yong philosophy and what were the changes he made in his later thought. Also, only after identifying the sources of Xiong's understanding of Reality and Function in this early phase can we see later in the thesis how his attitude towards these sources changed, what new sources he drew upon for his later writings, and, most of all, what the change and the new sources mean for his understanding of Reality and Function. Building on this chapter's clarification of Xiong's understanding of Reality and Function in the

320 Ibid., pp. 314, 317-327. It should be noted that, according to the examples provided in the "Yogācāra Critiques of the Two Truths", what Yao says to be the "Yogācāra school" refers actually to the Dharmapāla-Xuanzang tradition of Yogācāra. Indeed, as Alan Sponberg presents, there is another view in Yogācāra Buddhism, which believes that only the "nature of existence being perfectly accomplished" (the third of the three natures) truly exists, and which also presents a demarcation between existence and nonexistence. See Sponberg, "The Trisvabhāva Doctrine in India \& China”, pp. 101-103. 
early 1920s, Chapter Three will elaborate on how Xiong, mainly through two later writings in the 1920s, modified his views of the two levels of his ti-yong system, and how he finally combined the two levels into one. 


\section{Chapter Three}

\section{The Modification of Xiong's Conception of Reality and Function between 1923 and 1927}

After his presentation of a two-level ti-yong system in the early 1920s, Xiong began revising his views of Reality and Function in two subsequent works: Weishixue gailun, published in 1926; and Weishi lun, composed between the spring of 1926 and early 1927.321 Focusing primarily on these two works, this chapter examines the modification and development of Xiong's conception of Reality and Function in the mid-1920s. In what follows, I will, first, briefly introduce these two works, and then, on that basis, outline the structure and main arguments of this chapter.

\section{The 1926 Weishixue Gailun}

Xiong's 1926 Weishixue gailun is a revised version of his 1923 Weishixue gailun. According to Xiong, he began writing the 1926 work five years after beginning to study Dharmapāla's teachings when he entered the China Institute of Inner Learning in the second half of $1920 .^{322}$ It can be inferred from this that Xiong did not begin to work on the revised Weishixue gailun until the middle of 1925 at the earliest. Elsewhere, however, Xiong stated that in 1923 he suddenly started to doubt the "old learning" (jiuxue 舊學) - a reference to the Yogācāra learning represented by Xuanzang's Cheng weishi lun - and became extremely dissatisfied

\footnotetext{
321 In the Xiong Shili quanji 熊十力全集 (The complete writings of Xiong Shili), published by Hubei Education Press (Hubei jiaoyu chubanshe 湖北教育出版社) in 2001, the publication of Weishi lun is dated to 1930. However, this date is disputable. From my observation, this work should have been composed between spring 1926 and early 1927, and it is unlikely to have been published in 1930 . Since determining when Weishi lun was composed is essential to exploring how Xiong's understanding of Reality and Function changed and developed over time, this issue is clarified in the "Appendix" to this chapter.

322 Xiong, Weishixue gailun (1926) 唯識學概論 (一九二六年) (A general account of Yogācāra learning, published in 1926), in Xiong Shili quanji, vol. 1, p. 419.
} 
with the lineage of Dharmapāla that he had been following. Completely destroying his draft of the 1923 Weishixue gailun, he started to draft the 1932 Xin weishi lun. ${ }^{323}$ Since Xiong's 1926 Weishixue gailun is one of several drafts in the process of his writing the 1932 Xin weishi lun, this 1926 work is a "draft of the 1932 Xin weishi Iun". 324 This indicates that Xiong began drafting the 1926 work in 1923. Presumably, Xiong had prepared some manuscripts from 1923, but he formally started to compose his 1926 Weishixue gailun only after mid-1925. The "Introduction" (Xuyan 緒言) to Xiong's 1926 work is dated the second lunar month of 1926 (that is, between 14 March and 11 April, 1926 according to the solar calendar), ${ }^{325}$ which means that the 1926 work had been completed at that time.

Although the title was retained, Xiong's thinking in the 1926 Weishixue gailun differs significantly from that in the 1923 version. In particular, in the 1926 version, Xiong changed his view that Xuanzang's Cheng weishi lun and Kuiji's Cheng weishi lun shuji are the most authoritative Yogācāra texts. In the "Introduction" to the 1926 work, he clearly states that it was composed specifically to criticise and correct Dharmapāla's teachings as presented in the Cheng weishi lun. ${ }^{326}$ As shown in the previous chapter, Xiong's account of Reality and Function in the early 1920s was expressed principally through his explanations of certain Yogācāra theories of the Dharmapāla-Xuanzang lineage. Correspondingly, his modified understanding of Reality and Function in the mid-1920s is reflected in his critique and reconstruction of those theories.

According to Xiong, his dissatisfaction with Dharmapāla in the 1926 work primarily concerned Dharmapāla's discussions of Function. ${ }^{327}$ As we have seen, in his 1923 work Xiong presented a two-level ti-yong system. At the first level (the level of ultimate truth), suchness is Reality, and consciousness, which represents

\footnotetext{
323 Xiong, Xin weishi lun (wenyanwen ben, 1932), p. 9.

324 See Juzan, “Ping Xiong Shili suozhu shu”, p. 343.

325 Xiong, Weishixue gailun (1926), p. 419.

326 Ibid., pp. 418-419.

327 Ibid.
} 
the phenomenal world, is Function. At the second level (the level of conventional truth) of the ti-yong system, consciousness as Function is in turn sub-divided into Reality and Function: productive power is Reality, and manifest activity is Function. Indeed, as evident in his 1926 work, Xiong did not change his two-level ti-yong system, and his critique of Dharmapāla focused on the latter's theories concerning the concept of consciousness, productive power, and the relationship between productive power and manifest activity. By following Xiong's critique and reconstruction of these theories in the 1926 work, we can trace the changes in and the development of his understanding of Reality and Function in the mid-1920s.

\section{$\underline{\text { Weishi Lun }}$}

Nevertheless, as will be argued in this chapter, it seems that Xiong's views of suchness - as the level-one Reality or ontological Reality - and its relationship with Function did not change until he wrote Weishi lun, a work that further develops the thought presented in the 1926 Weishixue gailun.

As Xiong stated in his "Preface" (Daoyan 導言) to Weishi lun, the first and the second drafts of this work were the 1923 and the 1926 versions of Weishixue gailun, respectively. In terms of his propositions, the Weishi lun had changed completely compared to the first draft, and by as much as thirty or forty percent compared to the second. 328

Although the Weishi lun, on the whole, seems like a slightly modified version of the 1926 Weishixue gailun, there is an inconspicuous but significant change in Xiong's understanding of ontological Reality and its relation with Function, and perhaps this change was an important reason for Xiong to revise his 1926 work so soon after its completion.

328 Xiong, Weishi lun 唯識論 (Treatise on Yogācāra), in Xiong Shili quanji, vol. 1, p. 503. 


\section{The Structure and Main Arguments of this Chapter}

Because Xiong's 1926 Weishixue gailun and the slightly later Weishi lun represent two stages in the revision of his earlier views of Reality and Function dating from the early 1920s, this chapter, divided into two principal sections, discusses his thought in each work.

The first section (3.1) deals with three aspects of Xiong's ideas about Reality and Function in the 1926 Weishixue gailun: Xiong's critique of Yogācāra theories about consciousness and productive power; his reconstruction of the Yogācāra concept of transformation; and his account of suchness and its relationship with the phenomenal. By examining these three aspects of Xiong's thought, this section will show that Xiong still advocated a two-level ti-yong system in his 1926 work. First, he described Reality as a entire process of ceaseless transformation, and Function - namely, manifest dharmas - as that which is nominally discussed based on its two impetuses, compression ( $q u$ 屈) and extension (shen 申). In this way, he presented Reality and Function as non-dual. Second, he also noted that the "entire process of ceaseless transformation" belongs actually to the realm of Function, that is, the phenomenal realm, and suchness is its Reality. He maintained that Function is provisionally established only as an expedient means to reveal Reality. Since, apart from this relation, Xiong did not further establish a connection between suchness, as Reality, and the phenomenal realm, as Function, it seems that he presented them as two distinct things, just as he had in the 1923 work. The twolevel ti-yong system in Xiong's 1926 work can be demonstrated as:

Reality

level 1 suchness

level 2

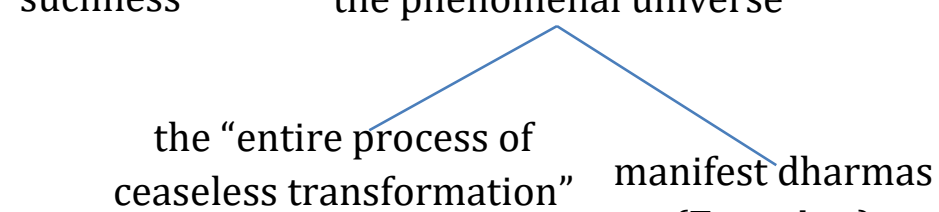

(Reality)

\section{Function}

(Function) 
The second section (3.2) examines the change in Xiong's understanding of ontological Reality and its relationship with Function as evidenced in Weishi lun. By examining certain statements in this work, I will argue that Xiong changed his view that the Yogācāra concept of suchness refers to ontological Reality, and instead came to regard the "entire process of ceaseless transformation" - the provisionally established, level-two Reality in the 1926 Weishixue gailun - directly as ontological Reality. This change can be shown as:

the 1926 Weishixue gailun

Weishi lun

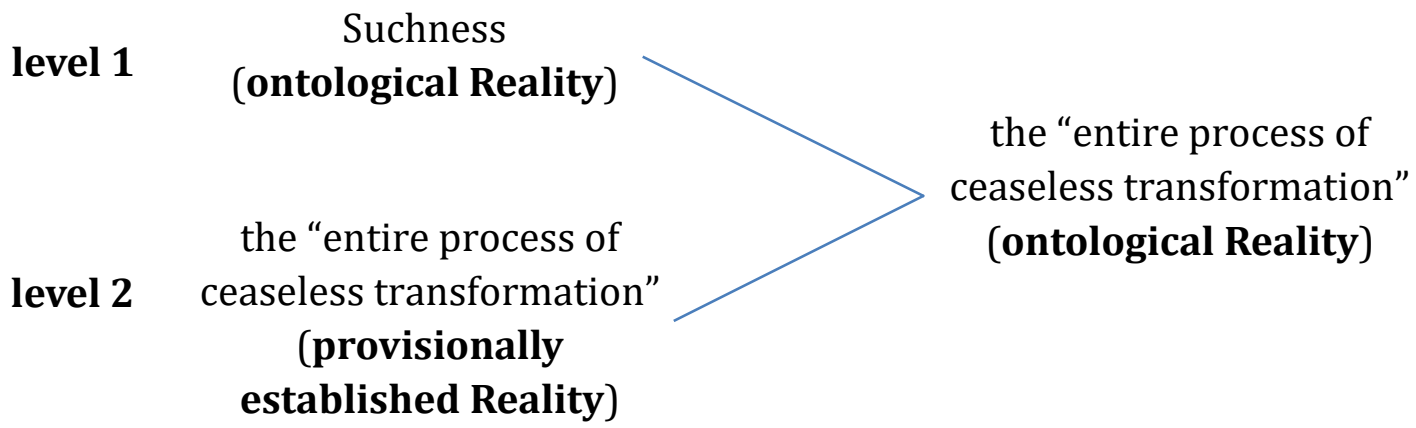

As such, Xiong abandoned a two-level ti-yong system, upholding only a single pair of Reality and Function: the "entire process of ceaseless transformation" as Reality (that is, ontological Reality), and manifest phenomena as Function. Further, by analysing Xiong's reinterpretation of the idea of "revealing Reality through Function" (ji yong xian ti 即用顯體), I will show that, corresponding to the change in his understanding of ontological Reality, when explaining this idea in his Weishi lun, Xiong changed his earlier view of Reality and Function as two distinct things. Instead, he maintained that Function is nominally posited on the basis of Reality and, since it does not have self-nature, it is no different from Reality. Therefore, in his Weishi lun, Xiong finally realised the non-duality of the ontological and the phenomenal. 


\subsection{Xiong's Understanding of Ti-yong in the 1926 Weishixue Gailun}

\subsubsection{Xiong's Critique of the Yogācāra Theories on Consciousness and Productive} Power

In his 1926 work, Xiong did not change his view that productive power and consciousness, or manifest activity, constitute a pair of Reality and Function, 329 but his understanding of the concepts of consciousness and productive power did change. To a large degree, this change is reflected in the transformation (from supportive to critical) of his attitude towards certain Yogācāra theories on these two concepts. Therefore, what follows examines Xiong's critique of those Yogācāra theories in the 1926 work, revealing his revised understanding of productive power, as Reality, and consciousness, as Function.

Xiong's critique of the Yogācāra concept of consciousness in his 1926 work focuses chiefly on two theories: the theory that consciousness comprises eight consciousnesses and fifty-one mental associates, with each consciousness and mental associate consisting of three parts (an image part, a perceiving part and a self-verifying part);330 and the theory of dependent arising. Through this critique, Xiong expressed his view that consciousness is not a real entity and thus does not have components. Since, for Xiong, consciousness subsumes all dharmas in the phenomenal world, then the entire phenomenal world is an indivisible whole in his thought.

As shown in Chapter Two, in his 1923 work, Xiong expressed his view that

\footnotetext{
329 Consistent with his view in the 1923 Weishixue gailun, in his 1926 work Xiong still identified the concept of manifest activity with the concept of consciousness (as representing all minds and mental associates). He sometimes called them "manifest consciousness" or "manifest dharmas" (xianfa 現 法). See, for example, Xiong, Weishixue gailun (1926), pp. 434, 458, 461.

330 According to Xiong, although Dharmapāla established four parts of consciousness (the image part, the perceiving part, the self-verifying part, and the re-witnessing part) in terms of the cognition of consciousness, he inherited Dignāga's idea of the three parts of consciousness (the image part, the perceiving part, and the self-verifying part) when talking about the transformation of consciousness. Ibid., p. 458.
} 
the phenomenal world is not outside the realm of consciousness by elucidating the Yogācāra theory of the "four parts" of cognition. In his 1926 work, he still believed that there was no cognitive object separate from or external to consciousness. However, he "proved" the point here only by refuting the ideas of those who believe in the existence of cognitive objects outside the realm of consciousness. He did not resort to the theory of the four parts of cognition at all. ${ }^{331}$ This is probably because, as the following passage shows, Xiong now rejected the idea that consciousness can be divided into constituent parts:

嘗謂護公持論條理繁密, 人鬚魚網猶不足方物。審其分析排比, 分析者, 如八識也、五十一心所也、三分也, 皆析為各各獨立之體。此一例也。餘義亦皆析如牛毛。 排比者, 如三分說本為量論上之問題, 而護法則以主張一切心、心所各各獨立之故, 勢不得 不排比整齊, 於是謂八識、五十一心所, 各各為相、見、自證三分。此一例也。自餘法數, 亦務為穿鏨排列。鈎心鬥角, 可謂極思議之能事。治其說者, 非茫無頭緒, 即玩弄於紛繁之名相而莫會玄旨; 縱别有會心, 亦終不能破陣而游。 332

[I] have previously said that the arguments proposed by Dharmapāla are well-structured, numerous, and intricately constructed - even fine human hairs and [tightly knit] fishing net are inadequate similes. Examining his breaking-down and parallelism, As for his "breaking-down", this is like the eight consciousnesses, the fifty-one mental associates, and the three parts, each of which he broke down into separate discrete constitutive entities. This is one example. He similarly broke down other doctrines in exhaustive detail. As for "parallelism", for instance, originally the doctrine of the three parts was an epistemological matter. However, because Dharmapāla asserted that each and every mind and mental associate was independent, he was compelled to make [all minds and mental associates] uniformly parallel. Accordingly, he stated that each and every

331 For Xiong's argument that there is no cognitive object separate from or external to consciousness in his 1926 work, see ibid., pp. 420-433.

332 Ibid., p. 459. 
one of the eight consciousnesses and fifty-one mental associates consisted of an image part, a perceiving part, and a self-verifying part. This is one example. As for other numerically based categories of Buddhist concepts, he similarly applied his efforts to making forced parallels. they are [full of] plotting and machinations, and can be said to be conceptualisation taken to the extreme. Those who study his doctrines are either confused and make no sense of them at all, or play around with the numerous complicated terms and definitions, failing to grasp the profound implications. Even if they have an extraordinary understanding of things, in the end they are still unable to break ranks and wander independently. 333

As this passage reveals, Xiong considered Dharmapāla's idea that consciousness can be differentiated into eight kinds of consciousness and fifty-one mental associates, and that each consciousness and mental associate can be further divided into three parts, as merely an example of his application of the methods of “breaking-down" (fenxi 分析) and “parallelism" (paibi 排比). For Xiong, Dharmapāla's “breaking-down” and “parallelism” are conceptualisations (siyi 思議) taken to the extreme, an impediment to the comprehension of the implications of his doctrines. Thus, from Xiong's perspective, Dharmapāla's division of consciousness into constituent parts is inappropriate: it is a conceptual method incapable of illuminating the real nature of consciousness. Xiong's objection to Dharmapāla's division of consciousness illustrates that, in his opinion, consciousness should not be broken down into components, just as he expressed elsewhere in the 1926 work that Function is a single whole that cannot be broken down into small components. ${ }^{334}$

Xiong's view of consciousness is evident in his critique of Dharmapāla's

333 Based on John Makeham's translation of the equivalent passage in Xiong's 1932 Xin weishi lun. See Xiong, Xin weishi lun (wenyanwen ben, 1932), p. 53; also, Makeham's translation of the passage in his New Treatise on the Uniqueness of Consciousness, pp. 122-123.

334 Xiong, Weishixue gailun (1926), p. 419. 
understanding of "dependent arising". As related in the previous chapter, in his 1923 work, Xiong believed that consciousness was generated through the aggregation of conditions, and by explicating this idea he showed that consciousness is devoid of self-nature. In the 1926 work, he still maintained that consciousness was not real by presenting it as dependently arisen. ${ }^{335}$ Yet he further emphasised that the theory of dependent arising was merely nominally established in order to refute the view that consciousness is real, and criticised Dharmapāla and Kuiji for understanding consciousness to be constituted by conditions:

夫緣生者, 本唯遮遣之詞, 不表構成之義。……護法、窺基之說緣生也, 直以現識從眾緣和合故生。眾缘者, 以緣有四, 名之為眾。蓋易遮遣之詞, 而 作進一層之說明。所謂進一層說明者, 破執爲第二義, 顯識構成爲第 一義。即以眾緣和合, 顯識所由構成, 次乃以緣合破執爲實也。遮遣 翻此, 但假說四緣, 徑破實物之執而止, 絕不欲顯識從眾緣構成。336

Originally, "dependent arising" was an expression only for refuting [those who are attached to the view that consciousness is a real entity]; it did not mean that [consciousness] is constituted by [conditions]. ... In talking about "dependent arising", Dharmapāla and Kuiji literally took manifest consciousness to be generated because of the coalescence of various conditions. As for [the expression of] "various conditions", because conditions include four kinds, they are said to be "various". They changed ["dependent arising" as] an expression for refutation, and then further elucidated [it]. In regard to this "further elucidation", refuting attachment [to the view that consciousness is a real entity] is a secondary aim; the primary aim is to show the constitution of consciousness. In other words, they used [the idea that consciousness is generated due to] the coalescence of various conditions to show what

\footnotetext{
335 See ibid., pp. 433-443.

336 Ibid., p. 444.
} 
constitutes consciousness. Only then did they use this idea to refute the attachment to [the view that consciousness] is real. ["Dependent arising" as an expression for] refutation is the opposite of this. We only nominally talk about the four kinds of condition, but directly refute attachment to [the view that consciousness is] a real entity, and then stop. We in no way mean to show that consciousness is constituted by various conditions.

According to Xiong's logic, it is not that consciousness is truly generated through the coalescence of conditions and thus cannot be a real entity (shiwu 實物), but rather that it is not a real entity in the first place and, to prove this point, it is provisionally analysed into various conditions. Xiong regarded the view that consciousness is constituted by conditions to be a distorted kind of attachment (bianxing zhi zhi 變形之執). According to him, if we were to acknowledge that conditions combine to constitute consciousness, then this can be likened to the convergence of the parts of a machine. How can consciousness be generated like this? $?^{337}$

By criticising Dharmapāla and Kuiji for misinterpreting the theory of dependent arising, Xiong argues that since consciousness does not truly exist, it surely cannot have components, and thus, we should not consider how it is constituted. As he points out:

當知現識是不思議變力, 宛爾幻現, 不應於彼作如何構成想。若作是 想，便已計有實物；既非實物，寧可作如何構成想耶？338

It should be understood that manifest consciousness is a transforming power, which is beyond conceptualisation and which manifests illusorily [as various phenomenal appearances]. We should not think about it in terms of how it is constituted. If one thinks this way, then one

\footnotetext{
337 Ibid.

338 Ibid., p. 445.
} 
has already reckoned that there exists a real entity. Since [consciousness] is not a real entity, how could we think about how it is constituted?

This further explains why Xiong objected to Dharmapāla's division of consciousness into eight consciousnesses and fifty-one mental associates, and further division of each consciousness and mental associate into three parts. Since consciousness is not a real existent and thus not to be considered in terms of its constitution, Xiong rejected Dharmapāla's division of consciousness into constituent parts. Xiong maintained that consciousness was not real and was beyond conceptualisation. Accordingly, in his 1926 work, he could apply only the apophatic mode of explanation to argue that there are no cognitive objects beyond consciousness or that consciousness is not a real entity. He attempted to demonstrate the former view by negating claims that cognitive objects exist outside the realm of consciousness. For the latter view, he appealed to the theory that consciousness is dependent arising, which he believed to be merely nominally posited for the purpose of refuting the idea that consciousness is a real entity.

Corresponding to his revised account of consciousness, Xiong also modified his account of the concept of productive power in his 1926 work by criticising certain Yogācāra ideas. That is, corresponding to his view that consciousness is not real and that the four kinds of condition are therefore merely nominally established, Xiong criticised the Yogācāra idea that productive power is the causal condition (yin yuan 因緣; hetu-pratyaya) for its manifest dharma. In line with his view that consciousness is indivisible, Xiong presented productive power as a complete whole, criticising the Yogācāra idea that there are numerous and various productive powers, or seeds. ${ }^{339}$ These two critiques of the Yogācāra concept of productive power are discussed in detail below.

\footnotetext{
339 As Xiong demonstrated, this Yogācāra idea was established on the basis of the division of consciousness into constituent parts. See ibid., pp. 462-463.
} 
As shown in Chapter Two, in his 1923 work, Xiong conceived of productive power as both the cause and the Reality of its manifest dharma. In 1926, however, he stated that productive power was only Reality rather than the cause of manifest dharmas, ${ }^{340}$ and criticised Dharmapāla for positing productive power as the causal condition for manifest dharmas. ${ }^{341}$

Xiong's critique of Dharmapāla's view is based on two points. First, according to Xiong, since manifest dharmas are not real entities, it is unreasonable to seek their cause. For example, everything we need in our daily life, such as food and drink, which ordinary people mistake as real, are produced by workers. The idea that there exists a "true ruler" (zhenzai 真宰) or “demiurge" (shengong 神工) as the cause of the generation of the universe and human life was deduced precisely from this understanding. For Xiong, although Dharmapāla objected to the idea that a lord of the universe and of human life exists, he had effectively taken manifest dharmas to be real entities and then inquired into their cause. ${ }^{342}$

Second, according to Xiong, to say that there is a cause of manifest dharmas is to refute the view that the emergence of manifest dharmas is "accidental" (ouer 偶爾). Despite this, Dharmapāla held that numerous seeds, as causes, generate their manifest dharmas only when all necessary conditions gather. This leads to the problem of explaining why the seeds meeting other conditions must be attributed to an "accident". Thus, Dharmapāla's perspective contradicts the original intention of the doctrine of dependent arising by establishing a cause for manifest dharmas. ${ }^{343}$ For Xiong, in order to refute the view that manifest dharmas are without cause, productive power is only nominally posited as the cause of manifest dharmas. Therefore, we should not consider it truly to be the cause of the

\footnotetext{
340 Ibid., p. 461.

341 It should be noted that what Xiong criticised is the view that productive power is truly the cause of manifest dharmas. In fact, he did not object to the idea that productive power can be nominally said to be the cause of manifest dharmas, which we will discuss shortly.

342 Ibid.

343 Ibid., pp. 461-462.
} 
generation of manifest dharmas and, thus, should not elaborate on the idea of it being a causal condition. ${ }^{344}$

Xiong insisted that productive power could not really be the cause of manifest dharmas because manifest consciousness (as representing all manifest dharmas) was not real but merely the manifestation of productive power. For him, the two cannot be considered to be two distinct entities, generator and that which is generated. Elsewhere in his 1926 work, Xiong clarified this point by criticising the Yogācāra doctrine of "the simultaneity of cause with its effect":

所謂識者, 非可偶爾突起, 從無肇有。故說功能, 爲其因緣, 以遮無 因邊見。在理論方面，祇合說到如此而止。若謂因功能。果現識。爲條然 各別，同時並有之二物，則剖析雖嚴，未免以法爾道理，作死物觀。 ……實則現識祇是功能之現起，如眼見色，此之一見，即是功能之現起耳。不可 別爲能所二物。說因為能生, 說果為所生, 此緣言說方便施設。在事實上, 豈可判以能 所二物。舊說果俱有義, 護法等說功能亦名種子, 此是能生因, 現識乃為所生果, 其果 與因, 同時並有, 故名果俱有。彼以因果看作二物, 故言俱有耳。所以成爲戲論。345

So-called "consciousness" is not something that can suddenly appear by accident or originate from nothingness. Thus, productive power is said to be its causal condition so as to refute the extreme view (antagrāhadrșți) that causes do not exist. ${ }^{346}$ In regard to this theory, that is all that needs to be said. If one claims that the cause productive power and the effect manifest consciousness are each distinct things yet coexist simultaneously, then, although this analysis is rigorous, one will inevitably treat them as static entities in the light of natural reason. ... Actually, manifest consciousness is only the manifestation of productive

\footnotetext{
344 On this point, see, also, ibid., p. 434.

345 Ibid., pp. 434-435.

346 “Extreme view" (bianjian 邊見; antagrāhadrșți) is the kind of view which goes to extremes and which is incorrect. Especially, it refers to the two extreme views that are attached to eternalism and nihilism, respectively. See Wu Rujun, Fojiao sixiang dacidian, p. 553.
} 
power, For example, as for the eyes seeing forms, this sight is indeed the manifestation of productive power. and they cannot be bifurcated as "subject" and "object". To say that the cause is the generator and the effect is that which is generated is postulated as a verbal expedient. But how can they be bifurcated as subject and object in actual fact? For this reason, the old interpretation of the doctrine of "the simultaneity of cause with its effect" Dharmapāla and others stated that productive power was also named seeds. It is the cause as generator, and manifest consciousness is the effect that is generated. The effect and the cause coexist simultaneously. This is therefore called "the simultaneity of cause with its effect". They viewed the cause and the effect as two [distinct] things, and so said that [the two] exist simultaneously. amounts to a conceptual elaboration (prapañca).

For Xiong, to say that productive power and manifest consciousness exist simultaneously is to say that they are two different things. From this perspective, the Yogācāra doctrine of "the simultaneity of cause with its effect" contradicts his view that productive power and manifest consciousness are non-dual. Moreover, because Xiong maintained that the relationship between productive power and manifest consciousness as cause/generator and effect/that which is generated was only nominally designated and thus should not be further analysed, he deemed the additional analysis of productive power and manifest consciousness into simultaneously existent entities in the Yogācāra doctrine of "the simultaneity of cause with its effect" as both false and unnecessary.

Nevertheless, Xiong's reason for claiming that the Yogācāra doctrine of "the simultaneity of cause with its effect" presents productive power and manifest consciousness as two distinct things is ill-founded. As discussed in Chapter Two, by advocating the simultaneity of cause and effect, Xuanzang rendered the former as the ground for the latter. For this reason, Xiong's support in his 1923 work for the idea of "the simultaneity of cause with its effect" does not contradict his view of productive power and manifest activity as non-dual. This shows that the thesis that 
productive power and manifest consciousness exist simultaneously does not entail that the two are ontologically distinct. Thus, Xiong's understanding in his 1926 work of the Yogācāra doctrine of "the simultaneity of cause with its effect" as indicating the duality of productive power and manifest consciousness appears to be superficial. His critique of this doctrine is perhaps a simple modus operandi to reinforce his own perspective that productive power and manifest consciousness as Reality and its illusory manifestation, respectively - are non-dual.

Another of Xiong's criticisms of the Yogācāra concept of productive power is that by developing the doctrines of Asanga and Vasubandhu, Dharmapāla dissected productive power into individual entities - that is, into numerous varied seeds that generate their own manifest dharmas - and then established the store consciousness (ālayavijñāna) as their repository. From Xiong's perspective, both the designation of productive power as "seeds" and the idea that each seed can produce its manifest dharma only of the same kind indicates that productive power is treated as analogous to objects ( $w u$ 物) (such as the seeds of rice) in the phenomenal world. Further, according to Xiong, ālaya (laiye 賴耶) means “locus” (chu 處), the "repository" (cangku 倉庫) where seeds are stored. This, again, draws an analogy with objects in the phenomenal world. Xiong dismissed the accounts of productive power by the Yogācāra masters such as Asanga, Vasubandhu and Dharmapāla as nothing but the "conceptualisation by the mental state of worldlings” (fanqing jidu 凡情計度). He insisted that productive power cannot be treated as an object and, since it is not an object, it cannot be dissected into individual parts and it does not need a place to be stored. In addition, he reasoned that if there are multitudinous seeds, which generate their manifest dharmas depending on other conditions, then the universe would be an accidental aggregation of extremely tiny particles or atoms (jiwei 極微; paramāṇu), and human life would be a combination of two types of seed, ${ }^{347}$ which is clearly a

\footnotetext{
347 According to Xiong, Dharmapāla divided seeds into two kinds: the seed of the image part of consciousness and the seed of both the perceiving part and the self-verifying part of consciousness.
} 
frivolous conceptual elaboration (xilun 戲論; prapañca). ${ }^{348}$ Above all, by criticising the division of productive power into individual seeds and the related ideas of the above-named Yogācāra masters, in particular Dharmapāla, Xiong presented productive power as a complete whole (quanti 全體) and incapable of division.

In his 1926 Weishixue gailun, Xiong had clearly changed his former attitude towards the Dharmapāla-Xuanzang lineage of the Yogācāra school, and criticised its account of productive power and consciousness, which reflects his revised understanding of these two concepts, respectively as Reality and Function. By criticising Dharmapāla for dividing consciousness into eight distinct consciousnesses and fifty-one mental associates, with each consciousness and mental associate having three parts, as well as criticising him for taking consciousness to be constituted by conditions, Xiong was giving expression to his view that consciousness is not a real entity and thus does not have components. For Xiong, consciousness subsumes all dharmas in the phenomenal world, and so the entire phenomenal world is an indivisible whole. Corresponding to his revised understanding of consciousness, Xiong also modified his account of productive power by criticising the idea that productive power is the cause of manifest dharmas, emphasising that productive power and manifest dharmas possess only a Reality-manifestation relationship rather than that of generator and that which is generated, and that the two are non-dual. He also criticised the idea that there are multitudinous productive powers or seeds, arguing that productive power is a complete whole that cannot be dissected. For Xiong, since manifest dharmas are not real, only productive power exists in the universe.

\subsubsection{Xiong's Reconstruction of the Yogācāra Concept of Transformation}

In his creative theory of “transformation” (zhuanbian 轉變), Xiong provides a more

Xiong, Weishixue gailun (1926), p. 463.

348 Ibid., pp. 462-464. 
detailed explanation of what manifest dharmas (or consciousness) truly are, what productive power is like as a complete whole, and how productive power is manifested as various dharmas. A chapter of the same title in his 1926 work, in which he introduced this theory, provides a detailed account of Xiong's understanding of the phenomenal world and its Reality. Xiong describes this chapter as the central part of his 1926 Weishixue gailun and where the fundamental difference between his and Dharmapāla's viewpoints is fully revealed. ${ }^{349}$ In what follows, I will examine Xiong's theory of transformation in that chapter because of what it reveals about his new understanding of ti-yong.

Xiong's theory of transformation is a reconstruction of the Yogācāra concept of transformation (zhuanbian 轉 變; parināma). The transformation of consciousness is a key concept in Yogācāra philosophy of mind and cognitive epistemology. For example, Xuanzang's Cheng weishi lun presents all experience as contained within the transformations of consciousness. That is, consciousness transforms into a perceiving part and an image part, which characterises a range of cognitive activities, including those of each of the eight consciousnesses. Seeds, emerging from the eighth or store consciousness (ālayavijñāna), give rise to, or transform into, the manifest activities of the first seven consciousnesses. Both seeds and these manifest activities cause or "perfume" future seeds. 350 As we have seen in Chapter Two, in the early 1920s, Xiong used the Yogācāra theories of these two kinds of transformation to explain the appearance of the phenomenal world. In his 1923 work, his account of the theories reveals his understanding of Reality and Function.

In his 1926 work, however, Xiong was critical of the theories of the two kinds of transformation explained above. According to Xiong, Dharmapāla divided "transformation" into two kinds: seeds functioning as causes that bring about transformation (yin nengbian 因能變); and manifest consciousness itself (xian ti

\footnotetext{
349 Ibid., p. 458.

350 See Makeham (trans. and annot.), New Treatise on the Uniqueness of Consciousness, p. xxxviii.
} 
現體) - that is, the self-verifying part of each mind and mental associate functioning as effects that bring about transformation (guo nengbian 果能變). ${ }^{351}$ The former refers to the generation of manifest activity by seeds; and the latter to the transformation of manifest consciousness itself, or the self-verifying part, into a perceiving part and an image part. 352 In Xiong's opinion, this is to take transformation apart, introducing a mistaken understanding of transformation:

迹護公立因果變, 若剖析靜物, 別無發揮。彼於因變中則以種為能變, 現為所 變; 於果變中則以自證為能變, 相、見二分為所變。乃將能所看作二物, 即若取已成之物或 靜物, 從而析為斷片者然, 是何足以明變耶? ……彼唯用分析之術, 乃不能不陷於 有所謂已成之斷片相狀，而無以明無方之變。353

[If we] trace Dharmapāla's establishment of the transformation of causes and the transformation of effects, [we will find that] it is like breaking down a static object and does not expound anything else. In regard to the transformation of causes, he took seeds to be the transformer and manifest activities to be that into which it is transformed; in regard to the transformation of effects, he took the self-verifying part to be the transformer, and the image part and the perceiving part to be that into which it is transformed. This is to regard transformer and transformed as two [distinct] things. In other words, this is like taking something that is already whole or a static object and then breaking it into fragments. How could this possibly illuminate transformation? ... Since he employed the method of breaking down, he could not avoid succumbing to so-called preconceived, piecemeal characterisations, and was then bereft of any means by which to illuminate

\footnotetext{
351 For the terms, yin nengbian 因能變 and guo nengbian 果能變, see Makeham's translation in his "Xiong Shili's Critique of Yogācāra Thought in the Context of His Constructive Philosophy", p. 255; New Treatise on the Uniqueness of Consciousness, p. 121.

352 According to Xiong's explanation, because manifest consciousness is the effect generated by seeds, all self-verifying parts are collectively called "effects that bring about transformation". See Xiong, Weishixue gailun (1926), pp. 458-459.

353 Ibid., p. 459.
} 
transformation, which lacks spatial extension. ${ }^{354}$

This critique of Dharmapāla's division of transformation into two parts, that which transforms (nengbian 能變) and that into which it is transformed (suobian 所變), clearly shows Xiong's view that since transformation lacks spatial extension (wufang 無方) - or to put it another way, it is not a real entity355 - it cannot be broken into parts like a static object.

According to Xiong, "transformation" is a concept that can be used as an expedient means to refer to the various material and mental dharmas in the phenomenal world, which, for him, are not real existents but rather illusory images. ${ }^{356}$ Xiong talked about transformation, beginning with two questions: who is the transformer and what is transformation? As for the first question, he answered:

爱有大用, 其名恆轉。恆言非斷, 轉表非常。非斷非常, 即刹那刹那捨其故而創新不 已。此所謂生力也, 經喻之如大瀑流。淵兮無待, 無有因故。湛兮無先, 非本無而後 有, 故云無先。有先則是本無。處卑而不宰, 卑者, 言其深細不可知也, 非如常途所云 高卑之卑。無實作用故, 不可說為神我或梵天等故, 故云不宰。守靜而弗衰。靜者, 言 其未嘗有作意以造作事業也, 非如常途所云不動之謂。弗衰者, 言其生生不息, 而幻現眾象 也。此則爲能變耳矣！357

Then there is a great Function, and it is called "constant transformation". "Constant" means "not interrupted"; "transformation" expresses the sense of "not eternal". Not interrupted and not eternal means instant by instant abandoning the past and endlessly creating the new. This is the so-called "power of generation", which

\footnotetext{
354 See Makeham's translation of the passage in Xiong's 1932 Xin weishi lun that corresponds to this one: Xiong, Xin weishi lun (wenyanwen ben, 1932), p. 53; Makeham (trans. and annot.), New Treatise on the Uniqueness of Consciousness, p. 122.

355 As for what Xiong meant by "transformation lacks spatial extension", see Xiong, Weishixue gailun (1926), pp. 452, 457.

356 Ibid., p. 447.

357 Ibid., p. 448.
} 
the sutra compares to a great torrent. ${ }^{358}$ It is profound, relying on nothing; This is because it has no cause. clear, having no beginning. It is not the case that originally it did not exist, and only later appeared. For this reason, it is said to have no beginning. To have a beginning is not to have existed originally. It resides in the obscure (bei 卑) and does not rule; "Obscure" describes its being profound, subtle and unknowable; here bei 卑 is not in the sense of "lowly", to which this character commonly refers. Because it does not have a real function, and because it cannot be spoken of as "soul" (purușa) or "the god Brahmā",359 it is said not to rule. preserves stillness (jing 靜) yet does not weaken. "Stillness" describes its having never had an intention to create affairs; here jing 靜 does not mean "motionless", to which this character commonly refers. "Not to weaken" describes its ceaselessly generating to manifest illusorily as various [phenomenal] appearances. This indeed is the transformer! ${ }^{360}$

In Xiong's opinion, the transformer - which he named "constant transformation" (hengzhuan 恆轉) - is an entire process of constantly abandoning the past and creating the new; a continuum of momentary transformations, or ceasing and arising. It is spontaneous and timeless, manifesting itself illusorily as various phenomenal appearances in the process of its ceaseless transformations. Since the

358 The "sutra" should refer to Trimśíkā, which says: "[Ālayavijñanna] constantly transforms like a torrent” (恆轉如瀑流). See Vasubandhu, Trimsśikā (Weishi sanshi lun song 唯識三十論頌; Thirty verses), trans. Xuanzang, in the CBETA edition of the Taishō Tripițaka, T31n1586_001, 0060b01. Xuanzang in his Cheng weishi lun interpreted this sentence as: “'Constant' is said in order to refute [the view] that [älayavijñana] is interrupted; 'transform' is to show that it is not eternal. [Ālayavijñāna] is just like a torrent” (恆言遮斷, 轉表非常, 猶如瀑流). Xuanzang, Cheng weishi lun, vol. 3, in the CBETA edition of the Taishō Tripițaka, T31n1585_003, 0012b25. This will be discussed below.

359 "Soul" (shenwo 神我; purușa) refers to the "eternally abiding self" attached by non-Buddhists. See Wu Rujun, Fojiao sixiang dacidian, p. 377. “The god Brahmā” (fantian 梵天) was originally a Vedic god, in early Indian religion seen as the basis of all things. In later Buddhist texts, the term fantian 梵天 gradually became a reference for the first of the four meditation heavens in the realm of form. See the Digital Dictionary of Buddhism, ed. A. Charles Muller, under the entry “梵天”.

360 See Makeham's translation of the passage in Xiong's 1932 Xin weishi lun that corresponds to this one: Xiong, Xin weishi lun (wenyanwen ben, 1932), p. 41; Makeham (trans. and annot.), New Treatise on the Uniqueness of Consciousness, pp. 95-96. 
phenomenal world is the illusory manifestation of constant transformation, constant transformation is the Reality of the phenomenal world. Indeed, Xiong identified constant transformation with productive power, the Reality of manifest dharmas, considering them to refer to the same thing, albeit with different names. ${ }^{361}$ Accordingly, Xiong's concept of constant transformation is his reconstruction of the Yogācāra concept of productive power.

Furthermore, Xiong's notion of "constant transformation" is obviously derived from Xuanzang's idea of ālayavijñāna, the store consciousness. In Xuanzang's translation of the fourth stanza in Vasubandhu's Trimśikā, it says: “[Ālayavijñāna] constantly transforms like a torrent” (恆轉如瀑流). ${ }^{362}$ In his Cheng weishi lun, Xuanzang interpreted this sentence as follows:

阿賴耶識爲衒爲常? 非斷非常, 以恆轉故。恆謂此識無始時來一類相 續, 常無間斷, 是界、趣、生施設本故, 性堅, 持種, 令不失故。轉 謂此識無始時來念念生滅, 前後變異, 因滅果生, 非常一故, 可爲轉 識熏成種故。恆言遮斷, 轉表非常, 猶如瀑流, 因果法爾。363

Is ālayavijñāna interrupted or eternal? It is neither interrupted nor eternal, because it constantly transforms. "Constant" means that since beginningless time this consciousness has continuously evolved as a homogeneous series without interruption, because it is the basis on which the realms of existence (dhātu), the destinies of reincarnation (gati), and the forms of birth (yoni) are established, ${ }^{364}$ and because its

\footnotetext{
361 Xiong, Weishixue gailun (1926), p. 460.

362 Vasubandhu, Trimśikā, trans. Xuanzang, 0060b01. Drawing on the scholarship of Shunkyō Katsumata 勝又俊教 (1909-1994), Tao Jiang notes that it was Xuanzang who, by following Dharmapāla, inserted the word "constant" (heng 恆) into Vasubandhu's Trimsśikā. In fact, in the original Sanskrit version of Trimssikā, the only word that implies such a meaning is srotasā, which means "as a stream or torrent". See Tao Jiang, Contexts and Dialogue, p. 67.

363 Xuanzang, Cheng weishi lun, vol. 3, $0012 \mathrm{~b} 25$.

364 According to Wu Rujun, here the "realms of existence" (jie 界; dhātu) refer to the desire realm (yujie 欲界; kāma-dhātu), the form realm (sejie 色界; rūpa-dhātu) and the formless realm (wuse jie 無色界; ārūpya-dhātu); the "destinies of reincarnation" (qu 趣; gati) refer to god (tian 天;
} 
nature is firm, it holds seeds and does not lose them. "Transform" means that since beginningless time this consciousness has been arising and ceasing in every thought-moment, changing from one thought-moment to the next, as cause ceases and effect arises. This is because it is not an enduring, single entity, and because it can be perfumed by the other seven consciousnesses to produce seeds. "Constant" is said in order to refute [the view] that it is interrupted; "transform" is to show that it is not eternal. It is just like a torrent - [the ceasing of] cause and [the arising of] effect is spontaneous. ${ }^{365}$

As for Xiong's explanation of the term "constant transformation" as "not interrupted and not eternal", he clearly drew on Xuanzang's description. Indeed, elsewhere in his 1926 work, Xiong notes that "constant transformation" and "productive power" are alternative designations for ālayavijñāna. ${ }^{366}$ This shows that he had noticed the close relation between these concepts in Yogācāra Buddhism, ${ }^{367}$ and highlights a connection between his reconstructed concept of productive power/constant transformation and Xuanzang's account of ālayavijñāna.

Nevertheless, Xiong's concept of constant transformation is by no means a simple appropriation of Xuanzang's idea of ālayavijñāna. As evidenced by Xiong's statement on constant transformation quoted above, he further developed the

deva-gati), human (ren 人; manusya-gati), hell (diyu 地獄; naraka-gati), hungry ghost (egui 餓鬼; preta-gati), and animal (chusheng 畜牲; tiryagyoni-gati); the "forms of birth" (sheng 生; yoni) refer to viviparous (taisheng 胎生; jarāyujā-yoni), oviparous (luansheng 卵生; andaja-yoni), born from moisture (shisheng 濕生; samsvedajā-yoni), and born spontaneously (huasheng 化生; upapâdukayoni). Together, the realms of existence, destinies of reincarnation and forms of birth refer to all things in the domain where sentient beings exist. Wu Rujun, Weishi xianxiangxue, p. 56.

365 I consulted Tao Jiang's translation of part of this passage in his Contexts and Dialogue, p. 66.

366 Xiong, Weishixue gailun (1926), p. 435.

367 As Wing-tsit Chan pointed out, in the Yogācāra school, constant transformation is identified with ālayavijñanna, and the energy to transform comes from "seeds" (another name for productive power), which "perfume" or influence previous seeds to produce transformation. Chan, A Source Book in Chinese Philosophy, p. 766. 
meaning of "neither interrupted nor eternal" - which, for Xuanzang, only means the perpetual arising and ceasing of ālayavijñāna every moment - so that it came to convey the sense of "instant by instant abandoning the past and endlessly creating the new” (刹那刹那捨其故而創新不已). Also, Xiong referred to constant transformation as the "power of generation" (shengli 生力), and presented one of its characteristics as "ceaselessly generating to manifest illusorily as various [phenomenal] appearances” (生生不息, 而幻現眾象). These descriptions of constant transformation as ceaselessly creating (chuang 創) or generating (sheng 生) is reminiscent of Zhouyi. As Zhang Dainian pointed out, Zhouyi dazhuan 周易大 傳 (A great commentary on the Book of Change) presents “generation” (sheng 生) as an important concept and considers the world to be a process of change, or ceaseless generation. 368 For example, in “Xici" 繫辭 (Appended statements), it says: “Ceaseless generation is what is called 'change”' (生生之謂易). 369 Kong Yingda 孔穎達 (574-648) in his Zhouyi zhengyi 周易正義 (The correct meaning of the Book of Change) interpreted this sentence as: ${ }^{370}$

生生, 不絕之辭。陰陽變轉, 後生次於前生, 是萬物恆生, 謂之易也。 371

"The generation of life" is a phrase that expresses the ceaselessness [of life]. Yin and yang transform and replace another, and what is produced subsequently follows what was produced before it. The myriad things are constantly generated, which is called "change".

Xiong's description of constant transformation as ceaseless generation seems to

\footnotetext{
368 Zhang Dainian, Zhongguo gudian zhexue gainian fanchou yaolun, pp. 114-115. Zhouyi dazhuan (or Yi dazhuan 易大傳) is another name for “Xici" 繫辭 (Appended statements), a work attached to Zhouyi as a general commentary on the gist of Zhouyi rather than an explanation of the text sentence by sentence.

369 See "Xici, shang", p. 149.

370 Kong Yingda was a scholar of Confucian classics in the Tang dynasty. Zhouyi zhengyi is a commentary by him and some other commentators on Wang Bi's and the Eastern Jin thinker Han Kangbo's 韓康伯 (332-380) annotations on Zhouyi.

371 Ibid.
} 
have a connection with these views.

Xiong's use of ideas drawn from Zhouyi is even more obvious in his answer to the second question about transformation, what is transformation? Through answering this question, he explained what manifest dharmas truly are and how constant transformation is manifested as various phenomenal appearances:

恆轉有屈申二行, 此言行者, 動勢義。屈申祇是兩種動勢, 而非兩種實體, 所以異乎二 元之論也。同時相感, 是名爲變。變不孤起, 孤即無待, 無待則非變。復無實 物, 若有實物, 亦無所謂變。故一屈一申方是變也。屈申皆動勢, 即無實物。一 屈一申, 即非孤起動。無勢不一, 乃以反而相濟, 故謂之變。申者, 闢而健往, 闢者, 開發義。健者, 精剛自勝, 即自在或自由義。往者, 施也, 謂其有似主宰用 而為能施也。然無實主宰者, 故言似耳。依此假說心法。屈者, 翕而順來, 翕者, 斂縮義, 斂縮故幻似形礙, 實則本無形礙也。順者, 頽墜義, 不自在義。來 者, 受也, 以其絕無主宰用, 但對彼一分能施而為受動故。依此假說色法。以故, 色無實事, 此言事者體義。言色法無實自體, 即無實物之謂, 下準知。心無實事, 祇 有此變。372

Constant transformation contains two activities, compression and extension. Here, "activity" means "impetus". Compression and extension are merely two kinds of impetus rather than two kinds of real entity. Hence, this is different from dualism. The simultaneous interaction between them is called "transformation". Transformation does not arise alone. "Alone" means "relying on nothing". If it relies on nothing, then it is not transformation. Moreover, it is devoid of any real thing. If it were to include a real thing, then it would not warrant being called transformation. Therefore, only one compression and one extension is transformation. Compression and extension are both impetuses; that is, [transformation] does not include any real thing. [Transformation consists of] one compression and one extension, which means that it is not something that arises alone. Neither of the two impetuses is not singular. It is precisely because

372 Xiong, Weishixue gailun (1926), p. 448. 
they are contrary yet complementary that this is called "transformation". Extension is expansive, ${ }^{373}$ and proceeds with vigour. "Expansive" means spreading out. "Vigorous" means extremely strong and self-controlling, that is, unconstrained or free. To "proceed" is to "bestow", which is to say, it has a function similar to that of a ruler and acts as bestower. Yet there is no real ruler, so it is said to be "similar". It is on this basis that mental dharmas are nominally posited. Compression is contractive and obediently passive. ${ }^{374}$ "Contract" means to converge. Because it converges, it illusorily seems to be physical resistance. In fact, there never was any physical resistance. "Obedient" means fallen, constrained. To "be passive" is to "receive". Because it absolutely lacks any function of a ruler it can only act as the receiver vis-à-vis that which is able to bestow. It is on this basis that material dharmas are nominally posited. Accordingly, material [dharmas] lack real entity, Here, "entity" means "nature". To say that material dharmas lack real self-nature is to say they lack [entity as] real things. This should be understood in the same way below. and mental [dharmas] lack real entity - there is only transformation.

As this passage shows, Xiong considered material and mental dharmas as nominal things established on the basis of the two impetuses - compression and extension - of constant transformation. Elsewhere in his 1926 work, Xiong states that socalled manifest dharmas are merely nominal conventions constructed on the basis of false discriminations (sui qing 隨情). ${ }^{375}$ This means that what we conceive as phenomena are not real entities but rather the two kinds of impetus of constant transformation: it is due to our false discriminations that we mistakenly take the kinds of impetus to be various dharmas. This further explains why constant

\footnotetext{
373 Later in the 1932 Xin weishi lun, Xiong directly used the term "expansion" (pi 闢) to replace “extension” (shen 申).

374 In the 1932 Xin weishi lun, Xiong directly used the term "contraction" ( $x i$ 翕) to replace "compression" ( $q u$ 屈).

375 Ibid., p. 462. Also, Xiong states that it is due to the mental associates of conceptualisation (xiang 想; samjjñā) and intelligence (hui 慧; prajñā) that we mistakenly take transformation to be material and mental phenomena. Ibid., p. 466.
} 
transformation is said to manifest as various illusory phenomenal appearances, and in what form Reality (constant transformation or productive power) and Function (the phenomenal world) are presented as non-dual.

From the above passage, we can also see that Xiong presented compression and extension as a pair of concepts which have contrary characteristics but which complement each other (fan er xiangji 反而相濟), and he believed that the interaction between them was precisely transformation. As such, the polarity of compression and extension in Xiong's philosophy falls into what Jana S. Rošker calls “binary categories” (duili fanchou 對力範疇). According to Rošker, binary categories are one of the fundamental characteristics of traditional Chinese philosophy. They are a kind of duality that seeks to attain the most real (possible) state of actuality through relativity, expressed in terms of the relation between two oppositional but interdependent notions. A distictive feature of binary categories is the principle of complementarity, which forms a basic method for their functioning. ${ }^{376}$ Thus, Xiong's concepts of compression and extension reflect his inheritance and development of traditional Chinese philosophy in terms of this fundamental characteristic of it.

In this respect, Xiong's explication of transformation as the interaction between compression and extension seems to have a strong connection with Zhouyi. In Zhouyi, there are two fundamental elements that constitute any trigram: the broken line of yin (yin yao 陰爻) and the unbroken line of yang (yang yao 陽爻). The difference between the trigrams lies in the different permutations or configurations of these two kinds of line. Since these two kinds of line are antithetical, and since the sixty-four hexagrams (each of which is made up of two trigrams) are taken to explain the changes of the myriad things in the universe, the

\footnotetext{
376 See Jana S. Rošker, "The Philosophical Sinification of Modernity and the Modern Confucian Paradigm of Immanent Transcendence (內在超越性)”, Asian Studies, vol. 2, no. 1, 2014, pp. 75-77; Traditional Chinese Philosophy and the Paradigm of Structure ( $\mathrm{Li}$ 理), Newcastle upon Tyne: Cambridge Scholars Publishing, 2012, pp. 11-16.
} 
Zhouyi actually presents those changes as being manifested in the interaction of two opposite elements. The two kinds of line in Zhouyi were later designated by some pairs of opposite concepts, in particular yin 陰 and yang 陽. 377 As Robin R. Wang observes, “contradiction and opposition" (maodun 矛盾) and “complementary or mutual support" (hubu 互補) are two features of the relation between yin and yang. 378 As for Xiong's account that the interaction between compression and extension is transformation, he seems to have been inspired by similar thinking in Zhouyi.

Moreover, the qian 乾 hexagram in Zhouyi consists of only yang lines, and the kun 坤 hexagram of only yin lines. Thus, it can also be said that all changes are the changes or movements of qian and kun. ${ }^{379}$ The Zhouyi presents the characteristics of qian and kun as vigorous (jian 健) and obedient (shun 順), respectively, ${ }^{380}$ which is consistent with Xiong's description of extension and compression.

Indeed, “compression” (qu 屈) and “extension” (shen 伸, or shen 申) are a pair of concepts that appear in the "Xici":

往者, 屈也; 來者, 信也。屈信相感, 而利生焉。381

That which goes is compression; that which comes is extension. Compression and extension mutually resonate, and benefits are generated therein.

As some scholars note, the character xin 信 in this statement is a variation of the

\footnotetext{
377 See Zhu Bokun 朱伯芘, Yixue zhexueshi 易學哲學史 (The philosophical history of the learning of the Book of Change), Beijing: Huaxia chubanshe, 1995, pp. 12-16.

378 See Robin R. Wang, "Yinyang Narrative of Reality: Chinese Metaphysical Thinking", in Chinese Metaphysics and Its Problems, eds. Chenyang Li and Franklin Perkins, pp. 22-23, 24-25.

379 See ibid., pp. 19-20.

380 See, for example, "Xici, xia" 繫辭下 (Appended statements, B), in Zhouyi zhengyi, Shisan jing zhushu, compiled by Ruan Yuan, vol. 1, p. 176; “Shuogua” 說卦 (Explanations of hexagrams), ibid., p. 184.

381 "Xici, xia”, p. 169.
} 
character shen 伸 (or shen 申). ${ }^{382}$ Furthermore, the connection between the interaction of compression and extension and the concept of "generation" (sheng 生 ) in this passage is also consistent with Xiong's account. Thus, as the contemporary scholar Lin Shirong 林世榮 points out, this statement is the likely inspiration for Xiong's use of compression and extension to describe transformation. ${ }^{383}$

Xiong also used the terms "contraction" ( $x i$ 翕) and "expansion" ( $p i$ 闢) to characterise compression and extension. As Makeham points out, contraction and expansion are two terms derived from Zhouyi, associated with the process of continuous change that features in that book. ${ }^{384}$ The "Xici" states:

382 See, for example, Lin Shirong 林世榮, Xiong Shili yu “ti yong bu'er” lun 熊十力與 “體用不二” 論 (Xiong Shili and the theory of "the non-duality of Reality and Function"), Taibei: Wanjuanlou, 2008, p. 251. Lin draws on Jingdian shi wen 經典釋文 (Phonetic and semantic explanation of the written words in the classics), composed by Lu Deming 陸德明 (ca. 550-630), a classical scholar of the Tang dynasty; and also Hanshu yin yi 漢書音義 (The pronunciation and meaning of the characters in History of the Former Han Dynasty), composed by Wei Zhao 韋昭 (204-273), a historian in the Eastern Han dynasty (25-220) and the Three Kingdom period (220-280). See also Song Xuehai 宋學海 and Wang Hui 王輝, Yijing 易經 (The Book of Change), Kunming: Yunnan renmin chubanshe, 2011, p. 434; Liu Junzu 劉君祖, Xiangjie Yijing Xici zhuan 詳解易經繫辭傳 (A detailed explanation of the "Appended Statements" in the Book of Change), Beijing: Xinxing chubanshe, 2011, pp. 153-154.

383 Lin Shirong, Xiong Shili yu “ti yong bu'er" lun, p. 251.

384 Makeham, "Xiong Shili on Why Reality Cannot be Sought Independent of Phenomena", p. 8. As Makeham notes elsewhere, closer to Xiong's own time, in the preface to his 1898 translation of T. H. Huxley's (1825-1895) Evolution and Ethics (1893), Yan Fu 嚴復 (1853-1921), an influential figure in translating many key Western writings, had also resorted to the concepts of contraction and expansion of the Zhouyi. See Yan Fu's original words in his Tian yan lun 天演論 (The theory of evolution), Beijing: Shangwu yinshuguan, 1981, p. ix. Similarly, as Makeham continues, in his “Zhelixue shi xu” 哲理學史序 (Prolegomena to a history of philosophy), Liu Shipei 劉師培 (18841919) identified the Aristotelian concepts of actuality (xiaoshi 效實) and potentiality (chuneng 儲 能) with "contraction" and "expansion" of the Zhouyi, and wei fa 未發 (not yet emerged into concrete manifestation) and zhong jie 中節 (emerged to be in a state of due modulation) of the Zhongyong, and Liu concluded that Chinese philosophy had relied exclusively on these texts (Zhouyi and Zhongyong) for its survival. Liu Shipei 劉師培, “Zhelixue shi xu” 哲理學史序 (Prolegomena to a history of philosophy), Guocui xиebao 國粹學報, 3 (1905): 4a-4b. See Makeham (trans. and annot.), New Treatise on the Uniqueness of Consciousness, p. xxxix, note 76. Xiong had already read Yan Fu's works by 1926, as he once commented on Yan and his works in 1920. See Xiong, "Tongxin (Xiong 
夫坤, 其靜也翕, 其動也䦣, 是以廣生焉。385

As for kun, when it is still, it is contractive; when it moves, it is expansive.

For this reason, it widely generates.

The "Xici" also uses the character he 闔, which has a meaning similar to $x i$ 翕, to form a conceptual polarity with "expansion":386

是故闔戶謂之坤，闢戶謂之乾，一闔一闢謂之變。387

Therefore, to close a door is called kun, and to open a door is called qian.

One closing and one opening is called "change".

Since the two pairs of concepts, "compression and extension" and "contraction and expansion", appear in "Xici" and are associated with "generation" or "transformation", Xiong's use of compression and extension to explain transformation, as well as his use of contraction and expansion to characterise compression and extension, supports the possibility that he turned to Zhouyi for expressing his own views of Reality and Function.

In drawing on Zhouyi for the idea that the interaction between yin and yang forms transformation, Xiong probably consulted Zhang Zai's interpretation of this idea. According to Zhu Bokun 朱伯芘 (1923-2007), an expert on Chinese philosophical history, Zhang Zai considered the source of all phenomena to be vital stuff, and interpreted the concept of “change” (yi 易) in Zhouyi as the process of the ceaseless transformations of two kinds of vital stuff, yin and yang. ${ }^{388}$ Since yin and yang, according to Zhang Zai, are both vital stuff, albeit with different

Zizhen yu Luo Zhixi)” 通信 (熊子真與羅志希) (Correspondence between Xiong Shili and Luo Zhixi), in Xiong Shili quanji, vol. 8, pp. 24, 25. Therefore, Yan's reference to the concepts of contraction and expansion of the Zhouyi may have inspired Xiong to use these concepts.

385 "Xici, shang", p. 150.

386 As Jing Haifeng explains, the two pairs of conceptual polarity in the "Xici", $x i$ and pi, and he and pi, have the same meaning. Jing, Xiong Shili zhexue yanjiu, p. 175.

387 "Xici, shang", p. 156.

388 Zhu Bokun, Yixue zhexueshi, p. 287. 
characteristics, they are not distinct things in nature. Indeed, Zhang Zai emphasised many times that these two kinds of vital stuff, or the entire world, are one. ${ }^{389}$ This perspective is consistent with Xiong's emphasis that his idea that constant transformation includes compression and extension as its two impetuses differs from dualism. Moreover, Zhang Zai described yang as that which “bestows” (shi 施) and yin as that which "receives" (shou 受), 390 which clearly resembles Xiong's depiction of extension as a bestower (nengshi 能施) and compression as its receiver (shoudong 受動).

On the other hand, even though there is only vital stuff, in Zhang Zai's view, this vital stuff intrinsically incorporates the two opposite modes of yin and yang. It is precisely because opposition exists that movement and change are possible. Opposites in Zhang Zai's conception usually refer to two opposite aspects of the movement and state of vital stuff,391 and "compression" (qu 屈) and "extension" (shen 伸) are important terms that he employed to describe a pair of contrary movements of vital stuff. For example, Zhang Zai stated that as for the vital stuff of yin and the vital stuff of yang, their "interaction through compression and extension is endless" (屈伸相感無窮). ${ }^{392}$ He also said that these two kinds of vital stuff “compress and extend infinitely, and move ceaselessly” (屈伸無方, 運行不息). 393 Furthermore, as Zhu Bokun demonstrated, Zhang Zai even believed that the transformation of things was fundamentally compression and extension. ${ }^{394}$ Given Zhang Zai's emphasis on compression and extension as a pair of contrary

\footnotetext{
389 See, for example, Zhang Zai, Zheng meng, pp. 63, 66; Hengqu Yi shuo 橫渠易說 (Hengqu's explanation of the Book of Change), in Zhang Zai ji, p. 231. See, also, Zhu Bokun's discussion of Zhang Zai's idea of "one thing with two states" (yiwu liangti 一物兩體) in Zhu, Yixue zhexueshi, pp. 298314.

390 Zhang Zai, Zheng meng, p. 12.

391 See the argument put by Jeeloo Liu in her "In Defense of Chinese Qi-naturalism", in Chinese Metaphysics and Its Problems, eds. Chenyang Li and Franklin Perkins, pp. 46, 47-48. See, also, Zhu Bokun, Yixue zhexueshi, pp. 292-301.

392 Zhang Zai, Zheng meng, p. 66.

393 Ibid., p. 12.

394 See Zhu Bokun, Yixue zhexueshi, pp. 295-296.
} 
movements of vital stuff that leads to its transformation, there is a strong possibility that Xiong drew on Zhang's thought for his own presentation of compression and extension as two kinds of movement or impetus of constant transformation.

When Xiong explained who the transformer is, he maintained that "emptiness" or "nothingness" (kongwu 空無) could not be the transformer, claiming that any view that takes "nothingness" to be able to generate "that which has characteristics" (you 有) is distorted. ${ }^{395}$ The objection to the idea that nothingness can generate that which has characteristics is a principle to which Zhang Zai adhered throughout the development of his philosophy of vital stuff. 396 In his Weishi lun - another work from the mid-1920s - Xiong praised Zhang Zai for stating that Zhouyi "does not talk in terms of having and not-having" (不言有無). ${ }^{397}$ This reinforces the possibility that Xiong drew upon Zhang Zai's thought for his own theory of transformation.

Xiong's interest in Zhouyi and preference for Zhang Zai's interpretation of it were rooted in his early period before 1920 . As we have seen in the Introduction of this thesis, in the first decade of the twentieth century, Xiong studied many secondary works on Zhouyi, and discussed such concepts as yin and yang, qian and kun, movement and quiescence with his friend He Zixin. ${ }^{398}$ Among these works on Zhouyi, Xiong was particularly fond of those on Zhang Zai's thought. 399 Therefore, it is not surprising that Xiong resorted to Zhouyi and to Zhang Zai's thought to

\footnotetext{
395 Xiong, Weishixue gailun (1926), p. 447.

396 On Zhang Zai's objection to the view that nothingness can generate that which has characteristics, see, for example, Robin R. Wang and Ding Weixiang, "Zhang Zai's Theory of Vital Energy", pp. 46-47; Qian Mu 錢穆, Song Ming lixue gaishu 宋明理學概述 (An overview of SongMing Neo-Confucianism), Beijing: Jiuzhou chubanshe, 2011, p. 53; Zhu Bokun, Yixue zhexueshi, pp. 255, 284-285. For a detailed introduction to Zhang Zai's view that there was never a state of nothing, see Jeeloo Liu, “In Defense of Chinese Qi-naturalism”, p. 46.

397 Xiong, Weishi lun, p. 558.

398 Also, in his essays published in 1913 in the magazine Yongyan, Xiong referred to Zhouyi and the secondary works on Zhouyi frequently. See Xiong, “Zheng ren xuehui qi” 證人學會啓 (A letter to the Academy for Demonstrating Humanity), in Xiong Shili quanji, vol. 8, pp. 1-5; "Da He Zixin shu”, p. 8; “Jian'an suibi”, pp. 9-11; “Jian'an suibi (xu)” 健庵隨筆 (續) (An essay in Jian'an [continuation]), ibid., pp. 14-16; “Yi jing lu xuyan”, p. 23.

399 See ibid.
} 
reconstruct Yogācāra theories.

Of course, Xiong's preference for Zhang Zai does not mean that he accepted Zhang's philosophy entirely. About the appearance of the phenomenal world, as demonstrated in Chapter One, Zhang Zai believed that everything in the phenomenal universe was constituted by vital stuff and generated through its movements. As Jeeloo Liu puts it, vital stuff is the formative as well as the constitutive cause of the world for Zhang Zai; that is, it is the stuff that causes and makes up the world's existence. Since, as Liu shows, Zhang considered vital stuff to be a real existent - it is the substance of all existents, and is indestructible and will never be annihilated, 400 this means that the phenomenal world in Zhang's philosophy exists and is not illusory. Indeed, as Robin. R Wang and Ding Weixiang illustrate, Zhang Zai specifically rejected the Buddhist view that the myriad things are only illusions. ${ }^{401}$ By contrast, Xiong believed that the phenomenal world was not real but merely nominally posited, and it is due to our false discriminations that it appears to be real. Thus, Xiong adopted only certain aspects of Zhang Zai's philosophy.

By drawing on Zhouyi, especially Zhang Zai's interpretation of it, Xiong reconstructed the Yogācāra concept of transformation. In his own theory of transformation, both mental and material dharmas are devoid of self-nature - there are only transformations existing in the universe, and transformer refers to the entire process of ceaseless instantaneous transformations, namely, constant transformation. Given that constant transformation is the only thing in the phenomenal universe, there is actually nothing to which it stands in contrast as the transformed. ${ }^{402}$ It was on this basis that Xiong rejected "the division of transformation into a subject and an object" in Yogācāra philosophy - that is, Dharmapāla's division of transformation into two parts, that which transforms and

\footnotetext{
400 See Jeeloo Liu, “In Defense of Chinese Qi-naturalism”, pp. 47-49.

401 Robin R. Wang and Ding Weixiang, "Zhang Zai's Theory of Vital Energy", p. 48.

402 As for this point, see Xiong, Weishixue gailun (1926), p. 459.
} 
that into which is transformed.

Through his own theory of transformation, Xiong further elaborated on those points he presented when he criticised the Yogācāra theories of consciousness and productive power. That is to say, since productive power refers to the entirety of ceaseless, instantaneous transformations, it is a complete whole and cannot be dissected into individual components. Since manifest dharmas are only the illusory appearance of constant transformation, then, naturally, consciousness (as representing all dharmas in the phenomenal world) is a single whole rather than something that can be broken down into components. Furthermore, since it is the two impetuses of constant transformation that are erroneously taken to be manifest dharmas due to our false discriminations, and since it is precisely the interaction between these two impetuses that is transformation, productive power or constant transformation is clearly Reality rather than the cause of manifest dharmas, and the two are non-dual as Reality and its illusory manifestation (Function), respectively.

\subsubsection{Ontological Reality, Its Function, and Their Relationship}

Despite Xiong's account of productive power/constant transformation as Reality and consciousness/manifest dharmas as Function, in the 1926 work he also expresses that vis-à-vis suchness productive power is Function. In the context of explaining who the transformer is, he states:

變不從恆常起, 恆常非是能變故。真實者, 真如異名, 此謂能變之實體, 而非即 能變, 以能變是用故。403

Transformation does not originate from constancy, for the reason that constancy is not the transformer. "Truth" is an alternative name for suchness. It refers to the Reality of the transformer but not to the transformer itself, because the transformer is Function.

403 Ibid., p. 447. 
It seems that the term "truth" (zhenshi 真實) in the auto-commentary can refer only to "constancy" (hengchang 恆常). This statement, especially the autocommentary to it, clearly shows that the transformer, that is, constant transformation, belongs to the realm of Function, and suchness, which is constant, is its Reality. ${ }^{404}$ Thus, suchness and constant transformation, or the whole phenomenal realm, constitute another pair of ti-yong.

Accordingly, in the 1926 work Xiong still presented a two-level ti-yong system: at the first level, suchness, which is constant, neither arising nor ceasing, is Reality; and constant transformation/productive power (as representing the whole phenomenal realm), which arises and ceases, ${ }^{405}$ is Function. At the second level, constant transformation/productive power is Reality; and consciousness/manifest dharmas, which arise and cease, 406 are Function. This apparently accords with Xiong's proposition of a two-level ti-yong system in his 1923 work, which, as quoted in the previous chapter, says: "That which neither arises nor ceases [that is, suchness] is Reality, and that which arises and ceases [that is, consciousness, as representing the whole phenomenal world] is Function. Within Function there is a further division into a Reality and a Function: productive power is the Reality within Function, and manifest activity is the Function within Function."407

In his 1926 work, Xiong describes suchness as Reality as follows:

世尊一大發明, 本爲宇宙究竟理。宇宙者, 本心境諸法之總名, 但吾宗不許有心 外之境, 本來無內外故。究竟理者, 即謂真如, 此是宇宙實體, 然非超脫現前宇宙而為其原

\footnotetext{
404 Thus, Guo Qiyong's 郭齊勇 claim that Xiong's 1926 Weishixue gailun directly takes productive power to be Reality (what Guo means by "Reality" is ontological Reality) is inaccurate. See Guo, Xiong Shili zhexue yanjiu, pp. 7, 33.

405 Xiong specifically noted that constant transformation itself was instantaneous arising and ceasing and thus could not be regarded as a real entity. Xiong, Weishixue gailun (1926), p. 465. For Xiong's detailed discussion of the arising and ceasing of constant transformation/productive power in his 1926 work, see ibid., pp. 464-465.

406 See Xiong's discussion of the arising and ceasing of manifest dharmas, or conditioned phenomena, in ibid., pp. 448-457.

407 Xiong, Weishixue gailun (1923), p. 129.
} 
因之謂。408

The Buddha's single greatest insight has always been that of the ultimate principle of the universe. The "universe" has always been a general name for the various dharmas of the mind's cognitive objects. However, our school [the Yogācāra school] does not assent to the existence of cognitive objects external to the mind, because there has never been a [demarcation between] the "internal" and the "external". The "ultimate principle" refers to suchness. It is the Reality of the universe. Yet this does not mean that it transcends the universe manifest before us and is its cause.

This expresses Xiong's perspective that suchness is the ontological Reality of the phenomenal universe. On this understanding, suchness is revealed through the phenomenal universe, its Function. This is a view that Xiong already held in his 1923 work. In what follows, I will discuss Xiong's interpretation of the idea of "revealing Reality through Function" in his 1926 work in detail, since his interpretation reveals not only his understanding of the relationship between ontological Reality and its Function, but also his understanding of constant transformation from the perspective of its being the Function at the first level of his ti-yong system (rather than being the Reality at the second level).

According to Xiong, the task of philosophy is to guide people to enter into (quru 趣入) the ultimate principle (jiujing li 究竟理), namely, suchness. As the ultimate principle, however, suchness cannot be expressed in words, and so various apophatic modes of explanation were established to refute the mistaken attachments of sentient beings and awaken them to that ultimate principle. ${ }^{409}$ For Xiong, the approach of revealing Reality through Function is precisely an application of the apophatic mode of explanation. To clarify this point, he first pointed out that the proposition "to reveal Reality through Function" is easily

\footnotetext{
408 Xiong, Weishixue gailun (1926), p. 445.

409 Ibid.
} 
misunderstood:

但云即用以顯, 則且計用上果可建立矣。不知體上固無可建立, 用上 又何容建立？設計用上可建立者, 則一談用時, 開口便死, 何足顯體? 如言唯識者, 以為實可建立唯識實有。則已執死此識, 更何從了其如如之實體耶? 410

As soon as it is stated, "to reveal through Function", then this is to reckon that [things] really can be established in Function. It is not understood that since there is certainly nothing in Reality that can be established, then how can [something] be allowed to be established in Function? If we presume that [something] can be established in Function, then no sooner is Function mentioned than it becomes a dead thing. How is it able to reveal Reality? For example, those who talk about "nothing but consciousness" believe that "nothing but consciousness" can truly be established as a real existent. In doing so they are stubbornly attached to this consciousness. How can they further apprehend its Reality as it really is?

Through the rhetorical questions presented in this passage, Xiong expressed his view that Function is not real and, thus, we cannot establish anything as a real existent in the realm of Function. If Function is a real entity, then it is impossible to find an additional Reality for it. For him, we can only provisionally establish things in Function, and it is precisely because discussions of Function by the Yogācāra school are only skilful means that its idea of "revealing Reality through Function" is reasonable:

故有宗談用, 所有施設, 原爲遮執, 故出權宜。如言唯識, 所以遮外境也。 而非建立唯識實有, 故又說緣生, 以遮執為實者。誰云有宗談用, 直表非遮? 吾 前言, 施設用義, 方便遮執。見卷首緒言。必於即用顯體之下益以此語, 而後無病。 以用義施設, 為遮執之方便, 故可即用而顯體也。411

Therefore, with respect to the Existence school's discussions of

\footnotetext{
410 Ibid., p. 446.

411 Ibid. For Xiong's view in this passage, see, also, ibid., p. 418.
} 
Function, ${ }^{412}$ all of its postulations originally proceed from expedience, with the purpose of refuting [mistaken] attachments. For example, it talks about "nothing but consciousness" so as to negate external objects; it does not establish "nothing but consciousness" as really existent. Thus, it further talks about "dependent arising" so as to refute those who are attached to [the view that consciousness] is real. Who says that the Existence school's discussions of Function are only kataphatic and not apophatic? As I stated previously, the referent of Function is postulated for the convenience of refuting [mistaken] attachments. See the "Introduction" at the beginning of this volume. We must add this sentence [as a supplementary explanation] to the phrase "revealing Reality through Function", after which [this phrase] will be without mistakes. Because the referent of Function is postulated [merely] for the convenience of refuting [mistaken] attachments, we can reveal Reality through Function.

This is an explicit statement of Xiong's view that Function, rather than being a real existent, is only provisionally established as a skilful means, in order to refute mistaken attachments. Xiong believed that only in this way could Reality be revealed through Function. As such, and consistent with his view in the 1923 work, Xiong still considered the idea of "revealing Reality through Function" to be an apophatic rather than a kataphatic mode of explanation.

We can deduce from this that Xiong's theory of transformation is provisionally established merely as a skilful means to refute the view that dharmas in the phenomenal world truly exist; it does not mean that there really exists something named "constant transformation" as the Reality of the phenomenal world. In Xiong's own words, this is similar to the theory of "nothing but consciousness", which is provisionally established to refute the view that external objects exist, but which does not mean that consciousness truly exists. Since the phenomenal world is nothing but constant transformation, and constant

412 The Existence school (you zong 有宗) refers to the Yogācāra school. 
transformation is merely a skilful means by which to reveal ontological Reality, then suchness, as ontological Reality, is all that truly exists. In the 1926 work, although Xiong considered suchness and constant transformation, or the phenomenal universe, to constitute the first level of his ti-yong system, he did not establish any connection between them. Therefore, it seems that he continued to present Reality without Function at this level, just as in his 1923 work. $^{413}$

Xiong's claim that the Yogācāra idea of "revealing Reality through Function" is an apophatic mode of explanation is probably a response to Ouyang Jingwu's view of this idea. In the transcript of his 1923 series of lectures, titled "Weishi jueze tan", Ouyang stated:

性相二宗俱談空義, 但性宗之談係以遮爲表, 相宗之談係即用顯體。 ……相宗談空所謂即用顯體者, 此蓋於能安立言詮之處 (即相) 直以表 爲表也; 故曰無能取所取而有二取之無。（此即顯空以無性爲性。）414 Both the Nature school and the Characteristics school discuss the meaning of "emptiness". 415 Nevertheless, the Nature school's

413 On this point, it should be noted that Xiong did not consciously indicate that there can be a Reality without Function, since, in traditional Chinese philosophy, ti and yong are a pair of concepts that stand in relation to each other. However, the influence of Yogācāra philosophy caused the contradiction between his use of this conceptual polarity and its original implication.

414 Ouyang, "Weishi jueze tan”, pp. 306-307.

415 The “Nature school” (xing zong 性宗), or “Dharma-nature school” (faxing zong 法性宗), is another name for the Emptiness school (kong zong 空宗), that is, the Madhyamaka school. The “Characteristics school” (xiang zong 相宗), or “Dharma-characteristic school” (faxiang zong 法相 宗), is another name for the Existence school, that is, the Yogācāra school. See Xiong, Fojia mingxiang tongshi, p. 358. According to Makeham, historically, both weishi 唯識 (nothing but consciousness; vijñaptimatra) and faxiang 法相 (dharma characteristics; dharma-lakșaṇa) were used to refer to the Yogācāra school in China. After the Tang dynasty, faxiang was used to denote Xuanzang's Yogācāra school but soon became a mildly derogatory expression used by its opponents to mock the Yogācārins for pursuing the "characteristics of dharmas" rather than the "real nature of dharmas" (faxing 法性; dharmatā). Despite this, Yogācārins later adopted the term. Makeham (trans. and annot.), New Treatise on the Uniqueness of Consciousness, p. xii. Yet, Ouyang Jingwu differentiated between the Characteristics school and the Weishi school. According to him, the Characteristics school refers to those whose teachings are based on the theories of "three natures" and "five dharmas" (wu fa 五法, that is, phenomenal appearances, names, discrimination, true insight, and 
discussion takes the apophatic as kataphatic, while the Characteristics school's discussion reveals Reality through Function. ... As for the Characteristics school's discussion of emptiness - that is, the so-called "revelation of Reality through Function" - this is because, in the locus where linguistic explanations can be established (that is, characteristics), they only take the kataphatic as kataphatic. Thus, they say that there is no grasper (grāhaka) or that which is grasped (grāhya) - there is the "absence" of both. (This shows precisely that emptiness takes the "non-nature" [of the two kinds of grasping] as its nature.)

Here, "emptiness" (kong 空) is equivalent to the "suchness" in Yogācāra Buddhism - both concepts refer to ontological Reality. With his explanation of the Yogācāra thesis of "revealing Reality through Function", Ouyang sought to express the view that because "grasper" (nengqu 能取; grāhaka) and "that which is grasped" (suoqu 所取; grāhya) - that is, the mind as perceiver and the objects that are perceived are both devoid of self-nature, this directly manifests Reality. In other words, the absence of the self-nature of the two kinds of grasping is Reality. This affirmation of the existence of Reality, as well as the description of it as the "absence", is precisely an example showing what he meant by "taking the kataphatic as kataphatic" (yi biao wei biao 以表爲表). Accordingly, Ouyang's account suggests that, although Realty is not identical with phenomenal appearances, it is also not different from them ( $f e i$ yi fei yi 非一非異). For this reason, Reality can be revealed through Function.

In fact, at the beginning of his discussion of "revealing Reality through Function", Xiong echoes the first sentence of Ouyang's statement:

suchness), while the Weishi school refers to those who focus on the characteristic of the dependent arising of dharmas. See Cheng Gongrang 程恭讓, Jueze yu zhen wei zhijian: Ouyang Jingwu foxue sixiang tanwei 抉擇於真偽之間——歐陽竟無佛學思想探微 (Choosing between the true and the false: an exploration of Ouyang Jingwu's Buddhist thought), Shanghai: Huadong shifan daxue chubanshe, 2000, p. 11. For an elaboration on Ouyang's distinction between the Characteristics school and the Weishi school, see Aviv, "Ouyang Jingwu: From Yogācāra Scholasticism to Soteriology", pp. 297-303. 
舊說空宗以遮爲表, 有宗即用顯體。其談有宗似猶未盡。416

It was said formerly that the Emptiness school takes the apophatic as kataphatic, while the Existence school reveals Reality through Function.

This [former] discussion of the Existence school seems incomplete.

Xiong's claim that "this [former] discussion of the Existence school seems incomplete" is a polite way of expressing his disagreement with that "discussion", and his own discussion of the idea of "revealing Reality through Function" is actually an objection to it. Indeed, as we have seen, Xiong believed that all discussions of Function by the Yogācāra school were only skilful means by which to refute mistaken views; under no circumstances could they directly manifest what ontological Reality is. This is obviously different from Ouyang's view. Also, Xiong's rhetorical question quoted earlier in this section, "who says that the Existence school's discussions of Function are only kataphatic and not apophatic?" (誰云有宗 談用, 直表非遮? ), appears to have been directed at Ouyang's assertion that the Characteristics school “only takes the kataphatic as kataphatic” (直以表爲表).

In addition, with the purpose of showing the necessity of manifesting Reality, Ouyang criticised Bhāviveka for "being only apophatic without kataphatic" (dan zhe wu biao 但遮無表) and so evidencing a "pernicious attachment" (e qu 惡取) to emptiness. In Ouyang's view, the Characteristics school "was not excessive" (wei wei guo 未爲過) in its criticisms of Bhāviveka's view. ${ }^{417}$ Correspondingly, Xiong also mentioned the Yogācāra school's refutation of Bhāviveka's view of emptiness when discussing the idea of "revealing Reality through Function". For Xiong, however, Bhāviveka's idea of emptiness was aimed only at refuting mistaken attachments to the existence of dharmas. Yet Dharmapāla failed to recognise Bhāviveka's intention, and so in seeking to correct Bhāviveka's idea of emptiness, he "was excessive" (tai guo 太過). As a result, Dharmapāla gave Function a substantive content and so ran

\footnotetext{
416 Xiong, Weishixue gailun (1926), p. 446.

417 Ouyang, "Weishi jueze tan”, p. 307.
} 
counter to the principle that Function is provisionally established merely to refute mistaken attachments. ${ }^{418}$ Xiong's critique of Dharmapāla clearly was in response to Ouyang's claim that the Characteristics school "was not excessive" in its criticisms of Bhāviveka. Further, in his 1923 work, Xiong did not object to the view that Bhāviveka had "a pernicious attachment to 'emptiness'”.419 Thus, his change of attitude towards Bhāviveka in the 1926 work is possibly because he wanted to use Bhāviveka's case as an example to illustrate the point that Function can only be nominally discussed as an expedient means by which to negate mistaken attachment, and to refute Ouyang's account of "revealing Reality through Function" at the same time.

In sum, although in the 1926 Weishixue gailun Xiong revised his previous understanding of the relationship between the level-two Reality, or conventional Reality, and its Function, he still presented a two-level ti-yong system and retained his views of the level-one Reality, or ontological Reality, and its relationship with Function. That is to say, previously in his 1923 work, Xiong considered productive power (the level-two Reality or conventional Reality) and manifest activity (the Function of productive power) to have a relationship of cause and effect, latent and manifest, and potential and actual. Later in his 1926 work, however, he reconstructed productive power into his own concept of constant transformation. He also considered manifest dharmas to be things which are nominally posited on the basis of its two impetuses, compression and extension, and which are illusory images generated by our false discriminations. In both the 1923 and the 1926 versions of his Weishixue gailun, Xiong presented productive power and manifest dharmas as constituting only the second level of his ti-yong system; he considered suchness to be Reality at the first level, or ontological Reality. Moreover, in both these works, by interpreting the idea of "revealing Reality through Function", he maintained that Function is not real and is only provisionally established in order

\footnotetext{
418 Xiong, Weishixue gailun (1926), p. 446.

419 See Xiong, Weishixue gailun (1923), p. 50.
} 
to negate mistaken attachment, and thereby enable suchness, as ontological Reality, to be revealed. In addition to this understanding, he did not establish any connection between ontological Reality and Function, and so he presented a Reality without Function at the first level of his ti-yong system in both works.

\subsection{Xiong's Understanding of Ti-yong in His Weishi Lun}

As will be shown in the "Appendix" to this chapter, Xiong composed his Weishi lun soon after he completed the 1926 Weishixue gailun. Therefore, he lacked sufficient time to write a new text, and added only some modifications to the 1926 work. ${ }^{420}$ Yet, a close examination of those modifications reveals that Xiong changed his views of ontological Reality and its relationship with Function, and that he abandoned the framework of a two-level ti-yong system. In this regard, Xiong's thought in the Weishi lun differs significantly from his previous work. This section will examine some of Xiong's modified statements in the Weishi lun, and compare them with the corresponding parts in the 1926 Weishixue gailun. It seeks to clarify Xiong's new understanding of ontological Reality and its relationship with Function in the Weishi lun.

\subsubsection{Ontological Reality}

In fact, nowhere in Weishi lun does Xiong indicate that he considered suchness to be the Reality of constant transformation and that he still presented a two-level $t i$ yong system. Indeed, he changed both statements made in his 1926 work which I quoted at the beginning of the section 3.1.3 in this chapter as evidence for proving that he used the concept of suchness to refer to ontological Reality. First, as we have

\footnotetext{
420 This is probably why Li Qingliang 李清良 and Guo Shengnan 郭勝男 believe that Xiong's thought in the Weishi lun did not substantially change compared with that in the 1926 Weishixue gailun. See Li Qingliang 李清良 and Guo Shengnan 郭勝男, “Xiong Shili Weishi lun zhuanzuo shijian kaobian” 熊十力《唯識論》撰作時間考辨 (An investigation into and clarification of the period of composition of Xiong Shili's Treatise on Yogācāra), Zhongguo wenhua yanjiu 中國文化研究, summer volume, 2009, pp. 40, 41-42.
} 
seen, when explaining why constancy is not the transformer, Xiong explicitly expressed his view that constant suchness is the Reality of the transformer, and the transformer is Function:

變不從恆常起, 恆常非是能變故。真實者, 真如異名, 此謂能變之實體, 而非即 能變，以能變是用故。421

Transformation does not originate from constancy, for the reason that constancy is not the transformer. "Truth" is an alternative name for suchness. It refers to the Reality of the transformer but not to the transformer itself, because the transformer is Function.

In his Weishi lun, however, when explaining why constancy is not the transformer, Xiong omitted the reference to suchness, and changed the explanation:

變不從恆常起, 恆常非是能變。觀夫萬變不窮, 知非離此而别有恆常之體。4 22

Transformation does not originate from constancy, and constancy is not the transformer. By observing the myriad, endless transformations, we [should] know that there is not an additional constant Reality apart from this.

As we can see, this modified statement no longer indicates that the transformer is Function, and that there is something else that is its Reality. Rather, since Xiong maintained that there is not an additional Reality apart from transformations, he actually negated his previous view that suchness, as the ontological Reality of the phenomenal universe, has no connection with transforming phenomenal appearances.

In the Weishi lun, Xiong also changed the other statement in his 1926 work that expresses the view that suchness is ontological Reality, and he omitted the reference to suchness. In his 1926 work, he stated:

世尊一大發明, 本爲宇宙究竟理。宇宙者, 本心境諸法之總名, 但吾宗不許有心

\footnotetext{
421 Xiong, Weishixue gailun (1926), p. 447.

422 Xiong, Weishi lun, p. 529.
} 
外之境, 本來無內外故。究竟理者, 即謂真如, 此是宇宙實體, 然非超脫現前宇宙而為其原 因之謂。423

The Buddha's single greatest insight has always been that of the ultimate principle of the universe. The "universe" has always been a general name for the various dharmas of the mind's cognitive objects. However, our school [the Yogācāra school] does not assent to the existence of cognitive objects external to the mind, because there has never been a [demarcation between] the "internal" and the "external". The "ultimate principle" refers to suchness. It is the Reality of the universe. Yet this does not mean that it transcends the universe manifest before us and is its cause.

Here, Xiong explicitly maintains that suchness is the ontological Reality of the phenomenal universe. In the Weishi lun, however, he changed the passage as follows:

世尊一大發明, 本爲宇宙究竟理。此言宇宙者, 乃心境諸法之總名。究竟理者, 即謂宇宙實體或人生實性。424

The Buddha's single greatest insight has always been that of the ultimate principle of the universe. Here the "universe" is a general name for the various dharmas of the mind's cognitive objects. The "ultimate principle" refers to the Reality of the universe or the true nature of human life.

Xiong might have omitted the reference to suchness to make his statement concise, but there remains the possibility that he did it because he did not want readers to misunderstand his view of ontological Reality. Xiong's understanding of ontological Reality and its relationship with Function in both the 1923 and the 1926 versions of Weishixue gailun seems to be consistent with the Yogācāra idea that suchness, albeit as ontological Reality, does not have any relation with the arising and ceasing of phenomena. Since Xiong had already abandoned this understanding of ontological Reality in his Weishi lun, he might have tried to avoid using the term

\footnotetext{
423 Xiong, Weishixue gailun (1926), p. 445.

424 Xiong, Weishi lun, p. 527.
} 
"suchness", in case it would cause confusion about his own view of ontological Reality. At the very least, since Xiong modified those two statements, and since he did not indicate that there is something else as the Reality of constant transformation elsewhere in the Weishi lun, the only thing that he presented in his Weishi lun as the Reality of the phenomenal world is constant transformation, or productive power. ${ }^{425}$ As a result, there is no evidence in that work to prove that he continued to present a two-level ti-yong system.

Indeed, in the Weishi lun Xiong changed his former view that constant transformation/productive power, as the Reality of the phenomenal world, is merely a provisional establishment, taking it instead to be ontological Reality directly. When Xiong argued that productive power is not the cause but the Reality of the phenomenal world, he described this Reality as:

余以爲現界自性本空, 自性猶言自體。唯依妄情執取故有。現界者, 乃意想之 所安立耳。以俗語表之, 即觀念或概念之妄結耳。若了現界實無, 則知因緣亦莫從 建立, 唯由妄情所執現界空故, 而本有不空實性, 方乃以如理作意得 深悟入。本有者, 法爾本然, 不由意想安立故。實性者, 本體之異名。作意者, 觀照義。 正智觀照, 契應正理, 遠離顛倒戲論, 故曰如理作意。元來只此實性, 別無現界與 之爲對, 不取色相, 不取心相, 乃至亦不取非色非心之相, 遠離一切意想境界, 冥然所遇 即真矣, 寂然本體呈露矣。寧復有所對可說為現界哉? 是故我說功能, 但依實性立 稱，不以因緣相釋。426

I maintain that the self-nature of the phenomenal world is inherently empty, "Self-nature" is like saying "self-entity". and it exists only because of the attachments of false discrimination. The phenomenal world is posited by the conceptions constructed by mental perceptions. To put it colloquially, it is a false formation by ideas or concepts. If one discerns that the phenomenal world in fact does not exist, then one would know that there is also no means

\footnotetext{
425 In his Weishi lun, Xiong did not change his theory of transformation, and he still identified the concept of constant transformation with his reconstructed concept of productive power.

426 Ibid., p. 543.
} 
for [its] cause as condition to be established. It is only because the phenomenal world to which false discriminations are attached is empty that true nature, which inherently exists and is not empty, can be profoundly realised and entered by means of proper attentiveness. "Inherently exist" means "naturally and inherently as such" because it is not posited by mental perceptions. "True nature" is an alternative name for Reality. "Attentiveness" means "reflection through accurate cognition". Reflection through accurate cognition by true insight accords with the truth and is far removed from delusive and mistaken conceptual elaborations. Therefore, it is said to be "proper attentiveness". There has only even been this true nature. Apart from it, there is no phenomenal world that stands in contrast to it. [If one] does not grasp the appearances of forms and minds, and also does not grasp the appearance of neither form nor mind, being far removed from all conceptual realms constructed by mental perceptions, then in profound mystery what one encounters will be precisely the truth, and in profound stillness Reality will reveal itself. How could there additionally be something that stands in contrast to this, which can be talked of as the phenomenal world? Therefore, in talking about productive power, I define it only on the basis of true nature, but do not explain it in terms of cause as condition. ${ }^{427}$

This passage appears only in Xiong's Weishi lun, not in his 1926 Weishixue gailun. In order to explain his account of the phenomenal world and productive power, Xiong drew on the Yogācāra theory of "three natures". For him, the phenomenal world is the product of the conceptualisation of things by the sixth consciousness. Those natures that are conventionally attributed to the objects in it are therefore only the "nature of existence produced from attachment to imaginatively constructed discrimination", the first of the three natures. As for productive power,

\footnotetext{
427 Based on Makeham's translation of the corresponding passage in Xiong's 1932 Xin weishi lun. See that passage in Xiong, Xin weishi lun (wenyanwen ben, 1932), p. 54; Makeham (trans. and annot.), New Treatise on the Uniqueness of Consciousness, p. 126.
} 
Xiong believed that it was the true nature of the phenomenal world and could be revealed only when imaginative constructions - that is, phenomenal appearances have been removed. This indicates that he considered productive power to be the "nature of existence being perfectly accomplished", the third of the three natures, namely, the ultimate truth. From Xiong's descriptions of productive power in this statement as "inherently existent", "not empty", "not posited by mental perceptions", and "be profoundly realised and entered by means of proper attentiveness", we can see that he actually regarded productive power as ontological Reality, rather than as something that is provisionally established simply to refute mistaken attachments. As such, in Weishi lun Xiong replaced the Yogācāra concept of suchness, as the "nature of existence being perfectly accomplished" or the ultimate truth, with his reconstructed concept of productive power. To put it another way, for Xiong, productive power is suchness, or ontological Reality. Just as different Buddhist schools have different understandings of what suchness is, Xiong understood it as productive power, or constant transformation. As a result, by this stage there were no longer two Realities (suchness as ontological Reality and productive power/constant transformation as a provisionally established Reality) in Xiong's philosophy but only productive power, or constant transformation, as ontological Reality.

Consistent with his abandoning the idea of the coexistence of two Realities, Xiong criticised Dharmapāla's dualistic notion of two Realities in his supplementary note following the above quotation. According to Xiong, Dharmapāla assented, on the one hand, to the existence of a Reality qua suchness (ruru zhi benti 如如之本體), while, on the other, to productive power as the cause as condition - that is, as the Reality - of the phenomenal world. Xiong then presented a rhetorical question: what is the relationship between "Reality qua suchness" and the "Reality of the phenomenal world"? This indicates that Xiong probably abandoned the idea of the coexistence of two Realities because he believed that it would result in a lack of connection between ontological Reality and 
the phenomenal realm, a point further discussed in the following section.

\subsubsection{The Relationship between Ontological Reality and Function}

In Weishi lun, since Xiong considered productive power or constant transformation to be ontological Reality, his understanding of the relationship between ontological Reality and Function here mirrors his understanding of the relationship between productive power/constant transformation and manifest dharmas. Xiong did not change his theory of transformation in Weishi lun. This means that in this work, he considered Function (manifest dharmas) to be the illusory manifestation of ontological Reality (productive power, or constant transformation), generated by our false discriminations and nominally posited on the basis of ontological Reality. As such, he presented ontological Reality and Function as non-dual.

In Weishi lun, Xiong further clarified his thesis that Function is the illusory manifestation of ontological Reality and so not different from ontological Reality by reinterpreting the idea of "revealing Reality through Function":

夫言即用顯體者, 固云體用自别, 但用不離體, 乃即用而顯體。不知 體上固無可建立，又安有别用可建立乎？設計有别用可建立者，則用 已與體對, 談用何足顯體? ……寀商以爲有宗顯體, 不妨於無可建立而假 有施設，即依體上故說爲用，而無别於體之用。428

As for those who talk about revealing Reality through Function, certainly they would say that although Reality and Function are different, Function is not separate from Reality. Thus, Reality is revealed through Function. They fail to understand that since there is surely nothing in Reality that can be established, how can there be an additional Function that can be established? If we assume that there is an additional Function that can be established, then Function would have already been in contrast to Reality. How can Reality be revealed

428 Xiong, Weishi lun, pp. 527-528. 
through discussing Function? ... I maintain that, in order to reveal Reality, the Existence school might as well provisionally postulate [a locus where] nothing can be established; that is, talk about Functioning on the basis of Reality, so that there is no Function that is different from Reality.

Xiong still believed that the thesis of "revealing Reality through Function" was problematic. Unlike in the 1926 Weishixue gailun, where Xiong proposes that this thesis is easily misunderstood to mean that Function is real, in the Weishi lun he additionally criticises it for presenting Function as different from Reality. For Xiong, if there truly exists a Function that is different from Reality, then this Function must have its own ontological basis that is distinct from Reality and therefore stands in contrast to Reality. ${ }^{429}$ In this way, it is impossible to reveal Reality through Function. Accordingly, Xiong's reinterpretation of the idea of "revealing Reality through Function" necessarily involves two aspects: Function is not real; and it is not different from Reality. The last sentence in the above passage elucidates these two aspects. We also note that Xiong further explained the "provisional postulation of Function" - an idea already highlighted in the 1926 work - for the purpose of presenting Function as no different from Reality.

In the supplementary note appended to his discussion of "revealing Reality through Function", Xiong also explains what he meant by "Function is nominally posited on the basis of Reality" and why Reality can be revealed through Function in a particular, restricted sense:

\section{吾用字係體之形容詞，乃即於體而假說爲用，形容其非頑空，即以表 示轉變。而對彼執有實色實心者, 正爲遮遣, 亦隱令彼悟非頑空。夫 悟非頑空, 則仍不妨隨俗假詮心色。而遮執實心實色, 則諸行之相既}

\footnotetext{
429 On this point, see also Xiong's supplementary note to his discussion of "revealing Reality through Function". Ibid., p. 528.
} 
空, 將其於體也, 自不難喻。430

I use the word "Function" as a descriptive term for Reality; that is, with respect to Reality I nominally posit it as Function to describe how it [Reality] is not complete emptiness. That is, I use [Function] to signify transformation. For those attached to [the view that] there exist real material and real mental [dharmas], this serves precisely to refute [their attachment], and also covertly to make them realise that [Reality] is not complete emptiness. Having realised that [Reality] is not complete emptiness, then we might as well follow convention and provisionally explain mental and material [dharmas]. Having refuted the attachment to [the view that there exist] real mental and material [dharmas], then since the characteristics of conditioned phenomena are empty, in leading them towards Reality naturally it is not difficult to make [those attached to the view that there exist real material and real mental dharmas] understand this.

This passage shows that for Xiong, Function does not refer to a real existent, but is nominally established to assume two roles: first, to demonstrate that Reality is not “complete emptiness" (wankong 頑空); and, second, to refute the attachment to the view that real dharmas exist, and thereby reveal Reality. Due to a lack of further elaboration in both this passage and its context, however, Xiong's explanation of how Function is able to fulfil these roles is unclear.

Xiong's overall understanding of Reality and Function in Weishi lun suggests one possible interpretation. As already discussed, in Weishi lun Xiong presents constant transformation/productive power as the sole Reality of the phenomenal world. As such, the above passage might be interpreted to mean that although the phenomenal world is not real, we can still nominally talk about it as Function because Reality and Function are non-dual. Since Reality has Function - albeit one

430 Ibid., p. 529. 
that lacks inherent nature and is in fact nothing but instantaneous transformation - it definitely cannot be said to be "complete emptiness".431 On the other hand, since the Reality of the phenomenal world is constant transformation, which means that the various dharmas cease as soon as they arise, then there has never been any existent dharma. After one has realised that the phenomenal world is empty and has stopped grasping phenomenal appearances, then, in Xiong's words, "in profound mystery what one encounters is precisely the truth, and in profound stillness Reality will reveal itself” (冥然所遇即真矣，寂然本體呈露矣). ${ }^{432}$

In the 1926 Weishixue gailun, by interpreting the idea of "revealing Reality through Function", Xiong explained that the provisional establishment of Function is nothing more than a skilful means to negate false attachments. In this, he made no connection between Function and the level-one Reality, or ontological Reality. When reinterpreting the idea of "revealing Reality through Function" in the Weishi lun, by contrast, he took pains to connect the provisionally established Function with ontological Reality. ${ }^{43}$ Indeed, his explanation of Function in the above passage was aimed precisely at Dharmapāla. According to Xiong, Dharmapāla took both Reality and Function to be real and made Function stand in contrast to Reality. As a result, in Dharmapāla's analysis, the two appear to have no obvious relation with each other. 434

Particularly noteworthy is Xiong's belief that Ouyang Jingwu's three-layered ti-yong system presented in the "Weishi jueze tan" was developed on the basis of Dharmapāla's "view", noted above, and was therefore unreasonable. As introduced

\footnotetext{
431 In a later writing, Xiong said: "That the meaning of Reality is established is because it has Function. If it does not have Function, then it is complete emptiness. How can it be named 'Reality'?" (體之爲義, 以有用故, 若無作用, 即是頑空, 如何名體? ) Xiong, “Jiangci” 講詞 (Speech), in Shili lunxue yu jilüe 十力論學語輯略 (Edited collection of Shili's discussions of learning), Xiong Shili quanji, vol. 2, p. 254.

432 Xiong, Weishi lun, p. 543.

433 It should be emphasised that there is only ontological Reality but no provisional Reality in the Weishi lun, and so the Reality discussed by Xiong in this work refers only to ontological Reality. 434 Ibid., p. 528.
} 
in Chapter Two, according to the transcript of the lecture series entitled "Weishi jueze tan", given in 1922, Ouyang presented a three-layered ti-yong system. The three layers are: Reality and Function in general, which refer to suchness and conditioned dharmas; the Reality and Function within Reality, which refer to the one true dharma-realm and the suchness revealed through eradicating the two attachments to the existence of a real self and the existence of real dharmas; and the Reality and Function within Function, which refer to seeds and manifest activities. Following his critique that Dharmapāla regarded both Reality and Function as real and so unconnected, Xiong states in his auto-commentary:

宜黃歐陽先生《唯識抉擇談》, 以體用各分二重。體上二重者：日體之 體, 謂一真法界; 曰體之用, 謂二空所顯是也。用上二重者: 曰用之 體, 謂種子; 曰用之用, 謂現行是也。詳此言體之體與用之體, 明將 體用看作兩種實有。蓋乃根據護法義以立言, 非憑臆造。435

In his "Weishi jueze tan", Mr. Ouyang of Yihuang takes both Reality and Function to be divided into two layers. The two layers of Reality are: the Reality of Reality, which refers to the one true dharma-realm; and the Function of Reality, which refers to [suchness] revealed through eradicating the two attachments to the existence of a real self and the existence of real dharmas. The two layers of Function are: the Reality of Function, which refers to seeds; and the Function of Function, which refers to manifest activities. Examining what is said here as "the Reality of Reality" and "the Reality of Function", this obviously regards Reality and Function as two kinds of real existent. [Mr. Ouyang] presented his idea based on Dharmapāla's doctrine rather than by fabricating it.

As noted earlier in Chapter Two, Ouyang's three-layered ti-yong system is a source for Xiong's own two-level ti-yong system, which was presented and developed in his 1923 and 1926 Weishixue gailun, respectively. Yet in Weishi lun, Xiong believed

435 Ibid., pp. 528-529. 
that Ouyang presented both Reality and Function as real. For Xiong, this means that it would be difficult to explain the relationship between Reality and Function. It would also contradict both Xiong's view that Function is illusory and also his intention to establish a connection between ontological Reality and Function. Consequently, Xiong's two-level ti-yong system, which he presented based on Ouyang's idea, was unsuitable to be presented in Weishi lun. He therefore abandoned it and instead presented only one pair of ti-yong - productive power/constant transformation as Reality (that is, ontological Reality) and the phenomenal world as Function. This also further explains why he objected to Dharmapāla's dualistic notion of two Realities.

\section{Concluding Remarks}

In the mid-1920s, Xiong revised his views of Reality and Function through two works, the 1926 Weishixue gailun and Weishi lun. In the 1926 Weishixue gailun, Xiong still presented a two-level ti-yong system. Just as in his 1923 work, he considered the concepts of productive power and manifest activity to constitute the second level of his ti-yong system. Nevertheless, he criticised certain Yogācāra theories on productive power and consciousness (as representing all manifest dharmas), and drew on the concept of "ceaseless generation" and the idea that the interaction between two opposite elements results in change (in particular Zhang Zai's interpretation of this idea), as found in Zhouyi. On these bases, he reconstructed the Yogācāra concept of productive power into an entire process of ceaseless transformation, and treated manifest dharmas as that which is provisionally posited on the basis of its two impetuses, compression and extension. Since, one compression and one extension constitute transformation, Xiong presented Reality and Function as non-dual at this level of his ti-yong system.

Yet, consistent with his views in the 1923 Weishixue gailun, Xiong believed that productive power was only nominally posited as Reality. In indeed, he still considered the Yogācāra concept of suchness to be ontological Reality, and 
maintained that productive power belonged to the realm of Function, that is, to the phenomenal realm. As such, suchness and productive power, or the phenomenal universe, constitute the first level of his ti-yong system. Xiong showed his view of ti-yong at this level by interpreting the Yogācāra idea of "revealing Reality through Function". By adopting the Madhyamakan approach of the apophatic mode of explanation, Xiong understood this Yogācāra idea to be apophatic rather than being kataphatic. He insisted that Function was not real but only provisionally posited in order to refute the view that manifest dharmas really exist. He believed that only in this way could suchness, as ontological Reality, be revealed. Xiong did not establish any connection between ontological Reality and Function in his 1926 work. Consequently, it seems that he still presented Reality without Function in the first level of his ti-yong system, just as he had in the 1923 work.

On his two-level ti-yong system presented in the 1923 work, Xiong only revised his views in the 1926 Weishixue gailun with respect to Reality and Function at the second level of his ti-yong system, or the level of conventional truth. He appears not to have changed his understanding of Reality and its relationship with Function at the first level of his ti-yong system, that is, the level of ultimate truth. To put it another way, what Xiong changed in the 1926 work is merely his explanation of the phenomenal world (in his 1923 work, both productive power and manifest activity belong to the phenomenal realm from the perspective of ultimate truth), whereas his perspective of the ontological and its relationship with the phenomenal was retained. That is to say, in the 1923 work, Xiong maintained that dharmas in the phenomenal world are generated by productive power, or numerous seeds, and the two have a relationship of cause and effect, latent and manifest, and potential and actual. Yet in the 1926 work, he reconstructed productive power into his own concept of constant transformation, and considered all material and mental dharmas to be things which are nominally posited on the basis of its two impetuses, compression and extension, and which are illusory images generated by our false discriminations. Despite the change in his understanding of the phenomenal world, 
in both the 1923 and the 1926 versions of Weishixue gailun Xiong believed that the Yogācāra concept of suchness is ontological Reality, and that it does not have any connection with the phenomenal realm, which is not real but only provisionally established.

It is in Weishi lun - a work composed soon after his 1926 Weishixue gailun that Xiong revised his understanding of ontological Reality and its relationship with Function. In it, he negated his previous view that ontological Reality does not have any connection with transforming phenomenal appearances. Rather, he presented it as inseparable from the myriad, endless transformations. In doing so, his understanding of ontological Reality finally ran counter to that in Yogācāra philosophy. Xiong also changed his view of productive power, or constant transformation, as being merely provisionally posited, instead maintaining that it was in fact ontological Reality. This means that in Weishi lun, Xiong abandoned his two-level ti-yong system, and presented only one pair of Reality and Function: productive power/constant transformation as Reality, and manifest phenomena as Function.

Correspondingly, Xiong modified his interpretation of the idea of "revealing Reality through Function". In both the 1923 and the 1926 versions of Weishixue gailun, he used it to express his view that Function is nominally posited for the purpose of refuting mistaken attachments, but seems not to have established any connection between Function and ontological Reality. In Weishi lun, however, Xiong maintained that Function was nominally established on the basis of ontological Reality and so was no different from ontological Reality. Hence, in Weishi lun, by presenting productive power/constant transformation as ontological Reality, and by modifying his interpretation of the idea of "revealing Reality through Function", Xiong finally realised the non-duality of the ontological and the phenomenal.

Although Weishi lun was composed in a hurry and Xiong's new ideas were neither fully elaborated nor clarified, this work should not be dismissed as a slightly modified version of the 1926 Weishixue gailun. Rather, it should be recognised as a 
crucial step in the development of Xiong's ti-yong philosophy.436

Xiong's selective adoption and sublation of Yogācāra learning, as well as his assimilation of ideas from other philosophical schools, in both the 1926 Weishixue gailun and the Weishi lun shows that he could avail himself of other ideas to elucidate his own understanding of Reality and Function at this stage. Most of all, by taking this approach, he successfully revised his views of Reality and Function, originally presented in the early 1920s, and integrated the two levels of his ti-yong system into one. The following chapter will explain how Xiong further developed this single-level ti-yong system in the decade after he finished writing the Weishi lun.

\section{Appendix: A Clarification of the Period Xiong Composed the Weishi Lun}

Although some scholars maintain that Xiong's Weishi lun was published in 1930, they have not indicated when it was composed. 437 In any case, this publication date is disputable. Determining when Weishi lun was composed is essential to exploring how Xiong's understanding of Reality and Function changed and developed over time. Contemporary scholars Li Qingliang 李清良 and Guo Shengnan 郭勝男 have already provided a detailed and generally convincing account identifying the period in which Xiong composed his Weishi lun. ${ }^{438}$ In what follows, I will clarify this issue by presenting only that evidence which I find to be compelling.

The Zun wen lu 尊聞錄 (Record of what has been respectfully heard) is a

\footnotetext{
436 As noted in the "Appendix" to this chapter, Li Qingliang and Guo Shengnan maintain that there is no substantial change between the 1926 Weishixue gailun and the Weishi lun, and that the only reason for Xiong to have composed another version of his account of Yogācāra learning soon after the completion of the 1926 version is that he wanted to provide a smoother, more accurate and more lucid set of teaching materials for the next school year. This assessment is unconvincing. See Li Qingliang and Guo Shengnan, “Xiong Shili Weishi lun zhuanzuo shijian kaobian”, pp. 40, 41-42.

437 See, for example: Cai, Xiong Shili xiansheng xuexing nianbiao, p. 24; Ding, Xiong Shili xueshu sixiang pingzhuan, pp. 27, 342; Guo Qiyong, Tian di jian yige dushuren, pp. 45, 240; Jing, Xiong Shili zhexue yanjiu, pp. 75, 272; Song Zhiming, Xiong Shili pingzhuan, p. 20.

438 See Li Qingliang and Guo Shengnan, “Xiong Shili Weishi lun zhuanzuo shijian kaobian”, pp. 38-44.
} 
collection of Xiong's sayings and letters between 1924 and 1928, recorded by Xiong's student Gao Zanfei 高贊非 (1906-1969), edited by another student Zhang Liming 張立民 (1900-1977), and self-published by Xiong in 1930.439 The work cites one particular passage of Xiong's writing that evidences his support for the Buddhist idea of transmigration (lunhui 輪迴; sampsāra).440 We can deduce that the passage was taken from the Weishi lun, because Gao Zanfei identifies its source as “the third draft of Xiong's book on Yogācāra” (唯識書第三稿). As already noted, Xiong regarded the 1923 and the 1926 versions of Weishixue gailun as the first and second drafts of Weishi lun, so the latter is naturally the third draft of his "book on Yogācāra". Furthermore, the only one of Xiong's works on Yogācāra that includes this passage is Weishi lun.441 Gao Zanfei further relates that when Xiong lived at Dayouzhuang 大有莊, Wanshoushan 萬壽山, Beijing, Xiong suddenly abandoned the idea of transmigration and destroyed the draft, admitting in frustration that his book had to be rewritten. ${ }^{442}$ According to the context of this account, the book that Xiong decided to rewrite refers undoubtedly to "the third draft of his book on Yogācāra", namely, the Weishi lun. According to some accounts, Xiong lived at Dayouzhuang in 1926. He moved from there to Nanjing in early 1927 to recuperate from illness, and then moved to Hangzhou later that year, returning to Beijing only in 1932.443 Therefore, Xiong must have decided to stop composing the Weishi lun no later than early 1927. Indeed, the last chapter, “Sefa” 色法 (Material dharmas), of Weishi lun has only two sentences, after which the book abruptly stops, which is consistent with Xiong's sudden decision not to continue writing this work.

Moreover, as I explain below, it seems that Xiong began to rewrite his Weishi

\footnotetext{
439 The last letter in this collection was written by Xiong in 1930 and added just before the collection's publication. See Gao Zanfei's note attached to this letter, in Xiong, Zun wen lu, p. 666.

440 See ibid., pp. 566-567.

441 See Xiong, Weishi lun, pp. 541-542.

442 Xiong, Zun wen lu, p. 567.

443 See, for example: Cai, Xiong Shili xiansheng xuexing nianbiao, pp. 22-28; Guo Qiyong, Tian di jian yige dushuren, pp. 43-59, 240-241; Ye, Xiong Shili zhuan, pp. 98, 219-221; Ding, Xiong Shili xueshu sixiang pingzhuan, p. 342; Jing, Xiong Shili zhexue yanjiu, p. 272.
} 
Iun not long after he abandoned the Buddhist idea of transmigration, and that this newly-composed book is the 1932 Xin weishi lun. According to Xiong, he had completed the first half of the 1932 Xin weishi lun when he was still in Beijing, before leaving early in 1927, and then composed the second half while recuperating in Hangzhou, that is, between 1927 and 1932.444 This indicates that from the time Xiong stopped writing his Weishi lun (even before he left Beijing in early 1927), he had focused on his new book, the 1932 Xin weishi lun, and there was no need for him to continue writing the Weishi lun. Thus, it is likely that Xiong never resumed writing his Weishi lun after he stopped composing it no later than early in 1927.

I have found no direct evidence to confirm the publication date of Weishi lun. Nevertheless, it is reasonable to speculate that in 1930, there was no reason for Xiong suddenly to publish a book he had already become dissatisfied with three years earlier.

Why, then, do some scholars believe that Xiong's Weishi lun was published in 1930? In 1930, Tang Yongtong noted: “With respect to the Xin weishi lun 新唯識論 (New treatise on the uniqueness of consciousness) that Mr. Xiong Shili formerly composed, its first draft proposed that sentient beings have many sources. The recent, fourth draft has changed to [the view] that sentient beings share the same origin” (熊十力先生昔著新唯識論, 初稿主眾生多元, 至最近四稿, 易爲眾生同 源).445 According to Li Qingliang and Guo Shengnan, some contemporary scholars such as Jing Haifeng and Guo Qiyong 郭齊勇 believe that the "fourth draft of Xiong's Xin weishi lun" in Tang's statement refers to Weishi lun, and it is probably for this reason that they consider it to have been published in 1930, based on the year Tang made the statement. 446 In Weishi lun, however, Xiong explicitly objected

\footnotetext{
444 Xiong, Xin weishi lun (wenyanwen ben, 1932), p. 9.

445 See Cai, Xiong Shili xiansheng xuexing nianbiao, p. 24.

446 Li Qingliang and Guo Shengnan, “Xiong Shili Weishi lun zhuanzuo shijian kaobian”, pp. 43-44. Li's and Guo's speculation is reasonable, since, as Jing Haifeng himself notes, his belief that Xiong's Weishi lun was published around 1930 is based on Tang's statement above. Jing, Xiong Shili zhexue yanjiu, p. 75 , note 2 .
} 
to the idea that sentient beings share the same origin. ${ }^{447}$ Thus, as Li Qingliang and Guo Shengnan propose, the "fourth draft of Xiong's Xin weishi lun" refers not to Weishi lun, but probably to the unfinished draft of the 1932 Xin weishi lun. ${ }^{448}$ As such, the claim that Xiong's Weishi lun was published in or around 1930 is unconvincing.

Xiong's Weishi lun must have been composed between spring 1926 (when he completed the 1926 version of Weishixue gailun) and early 1927. Although the publication date cannot be precisely determined, it unquestionably reflects Xiong's thought in the mid-1920s rather than his thought around 1930.

We might ask then: why did Xiong compose a new version of his treatise on Yogācāra learning shortly after he completed the 1926 version? According to Li Qingliang and Guo Shengnan, Xiong's thought in Weishi lun did not substantially change from his thought in the 1926 Weishixue gailun, and his statement in his "Preface" to Weishi lun that the former had changed by as much as thirty or forty percent compared to the latter is reflected only in its verbal form and not in its basic content. Thus, Li and Guo believe that the only reason for Xiong to have composed the Weishi lun soon after completing the 1926 Weishixue gailun is that he wanted to provide a smoother, more accurate and more lucid set of teaching materials for the next school year. ${ }^{49}$ Nevertheless, from what I have demonstrated in this chapter, we can see that Xiong's understanding of ontological Reality and its relation with Function differs significantly between Weishi lun and the 1926 Weishixue gailun. This change suggests a strong reason for Xiong to compose a new version of his account of Yogācāra learning in Weishi lun, even so soon after his completion of the 1926 version.

\footnotetext{
447 See Xiong, Weishi lun, pp. 541-542.

448 Li Qingliang and Guo Shengnan, “Xiong Shili Weishi lun zhuanzuo shijian kaobian”, p. 43.

449 Ibid., pp. 40, 41-42.
} 


\section{Chapter Four}

\section{The Development of Xiong's Conception of Reality and Function between 1927 and 1937}

Based on his thoughts in Weishi lun, Xiong continued to develop his conception of Reality and Function between the late 1920s and mid-1930s. ${ }^{450}$ His new ideas about Reality and Function are reflected in his many sayings and writings in this period, with the most important undoubtedly being the 1932 Xin weishi lun. This 1932 work thoroughly expounds Xiong's understanding of Reality and Function at this stage, and it is widely considered to represent the establishment of his mature ti-yong philosophical system. In addition to this work, Xiong also expressed his views of Reality and Function in other writings, mainly in some of the passages in Zun wen lu that record his sayings in 1927 and 1928;451 his 1933 writing, "Po 'Po

450 Although Xiong's views, such as his epistemological perspective, may have changed from the late 1920s to the mid-1930s, his understanding of ti-yong - that is, what Reality is, what Function is, and what their relationship is - is generally consistent during this period. Relevant to this, it should be noted that Li Qingliang's and Xu Yangnan's 許揚男 claim that Xiong moved from maintaining an “incomplete Reality” (fei xianchengxing benti 非現成性本體) in the Zun wen lun to maintaining a “complete Reality" (xianchengxing benti 現成性本體) in the 1932 Xin weishi lun is unfounded. According to Li and $\mathrm{Xu}$, in Zun wen lun, Xiong held that Reality is not originally complete and that it needs to be "created" (chuang 創) and "expanded" (kuochong 擴充) by us; but in his 1932 work, Xiong changed this view and presented Reality as originally complete. See Li Qingliang and Xu Yangnan 許揚男, “Ma Yifu dui Xiong Shili Zun wen lu zhi yiyi ji qi yingxiang”馬一浮對熊十力《尊 聞錄》之異議及其影響 (Ma Yifu's objection to and its influence on Xiong Shili's Record of What Has been Respectfully Heard), Beijing daxue xuebao (zhexue shehui kexue ban) 北京大學學報 (哲學社會 科學版), vol. 46, no. 2, 2009, pp. 93-98. However, what Xiong really meant in the Zun wen lu is not that Reality is incomplete, but rather that because we are confined by our human body it is difficult for us to fully manifest our Reality, and so we have to reveal Reality gradually by making efforts to maintain and cultivate (cunyang 存養) our inherent mind (benxin 本心), or Reality. See Xiong, Zun wen lu, pp. 605-611. This actually is a matter of epistemology rather than ontology.

451 Although the Zun wen lun is mainly a record of the changes in Xiong's thought from 1924 to 1928 (see Guo Qiyong, “Bianzhe houji” 編者後記 [Postscript from the editors], in Xiong Shili quanji, vol. 1, p. 672), as Li Qingliang and Guo Shengnan point out, most of Xiong's ideas in this work were formed in 1927 and 1928 because those ideas could only have been based on the premise of Xiong's 
Xin weishi lun'” 破《破新唯識論》 (Refutation of the “Refutation of the New Treatise on the Uniqueness of Consciousness");452 and certain articles in Shili lunxue yu jilüe 十力論學語輯略 (Edited collection of Shili's discussions of learning), a collection of his notes and letters between 1932 and 1935. All of these writings shed light on Xiong's ideas in his 1932 work and can help us better comprehend his understanding of Reality and Function at this stage. ${ }^{453}$

This chapter deals mainly with the 1932 Xin weishi lun, as well as with the other writings mentioned above, in order to show how Xiong, after writing his Weishi lun, further developed his conception of Reality and Function between 1927 and 1937. This chapter is divided into three main sections. As a background, the first section (4.1) points out that Xiong experienced a change from considering each sentient being as having its own Reality to believing in a single Reality shared by all sentient beings and that his views of Reality and Function between 1927 and 1937 are premised on the latter. The second section (4.2) discusses Xiong's two new ideas about Reality in this period: his identification of Reality with our mind; and his characterisation of it as both transforming and constant. The third section (4.3) examines the development of Xiong's understanding of the relationship between Reality and Function, with a focus on his two most conspicuous ideas. First, it is precisely Function that is Reality (ji yong ji ti 即用即體). Crucially, this does not mean that Function is identical to Reality; it means that Function is devoid of selfnature and thus ontologically is not different from Reality. This provides Xiong with a basis on which to present his explanation of the idea of "revealing Reality through

\footnotetext{
objection to the Buddhist idea of transmigration and his support for the view that sentient beings share the same origin, which occurred after he stopped writing the Weishi lun by early 1927. Li Qingliang and Guo Shengnan, "Xiong Shili Weishi lun zhuanzuo shijian kaobian”, p. 44.

452 This writing is Xiong's response to the criticism of his 1932 Xin weishi lun by Liu Dingquan 劉 定權 (1900-1987), a student from the China Institute of Inner Learning.

453 Although Xiong's Fojia mingxiang tongshi was published in 1937, he started to compose it in the early 1920s, and so it retains some content that reflects Xiong's ideas before the late 1920s. Therefore, I did not include this work as representative of Xiong's thought between the late 1920s and mid-1930s, but I referred to it where relevant to the broader context of this thesis.
} 
Function” (ji yong xian ti 即用顯體). Second, a single Reality permeates everything in the phenomenal world, and each individual thing is therefore a manifestation of the entire Reality. As a result, for Xiong, all things in the phenomenal world are mutually inclusive without obstruction.

This chapter concludes that, by drawing primarily on the idea of "the two aspects of the one mind" (yixin ermen 一心二門) presented in the Dasheng qi xin lun, the concept of "the inherent mind" (benxin 本心) in the Neo-Confucian School of Mind, in particular Wang Yangming's development of it, and the Huayan doctrines of "the unobstructed interpenetration of the absolute and the phenomenal" (li shi wu'ai 理事無礙) and "the unobstructed interpenetration of each and every phenomenon" (shi shi wu'ai 事事無礙), along with Ma Yifu's influence, Xiong further developed his conception of Reality and Function and interpreted the idea of "the non-duality of Reality and Function" in a new way between the late 1920s and mid-1930s. He identified Reality with our mind, and presented it as having two aspects: transformation (bianyi 變易) and constancy (buyi 不易), or movement (dong 動) and quiescence (jing 靜). Transformation/movement is described in terms of its illusory manifestation, that is, Function. Constancy/quiescence is described in terms of its inherently unchanging nature, that is, Reality itself, or the inherent mind (benxin 本心). Because Function is devoid of self-nature, it does not differ from Reality. In this sense, the two are non-dual. This new understanding of Reality and Function can be demonstrated as follows:

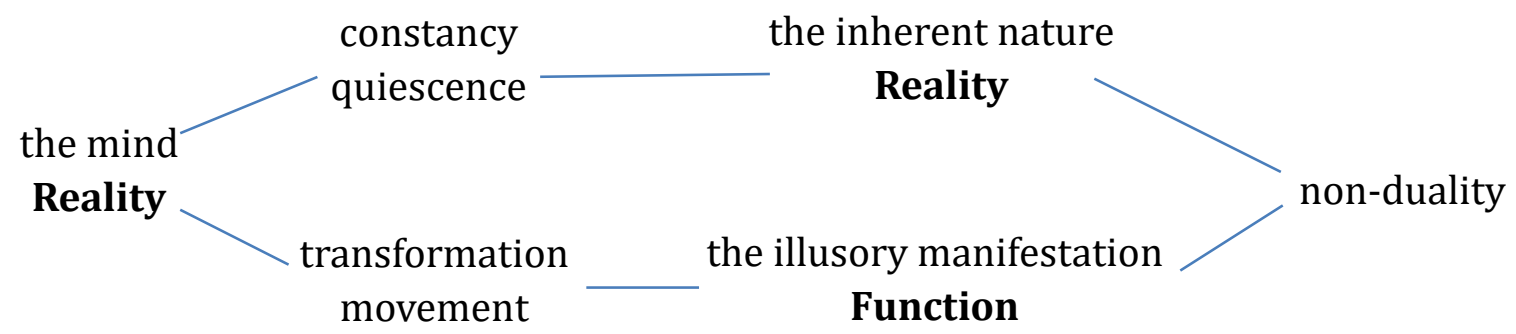


Moreover, this chapter also concludes that this new understanding of Reality and Function is consistent with the Dasheng qi xin lun and indicates Xiong's further deviation from the Yogācāra school. By presenting this new understanding, Xiong responded to the "genuine Buddhism" movement and its related debates, which, as introduced in Chapter One, reflects an antagonism between the DharmapālaXuanzang tradition of Yogācāra and the Dasheng qi xin lun.

\subsection{Whether or Not Sentient Beings Share the Same Reality}

Before talking about how Xiong, based on his thinking in Weishi lun, developed his conception of Reality and Function between the late 1920s and mid-1930s, it should first be noted that there was a change in his understanding of Reality between the Weishi lun and the writings in this period. In Weishi lun, Xiong believed that each sentient being has its own Reality. Yet in the period between the late 1920s and the mid-1930s, Xiong changed this perspective, maintaining instead that there is only one Reality shared by all sentient beings. As will be shown later in this chapter, this change was a prerequisite for Xiong's presentation of his new ideas of Reality and Function. Thus, in what follows I will discuss this change in detail.

In Weishi lun, although Xiong presented productive power, or constant transformation, as Reality, he did not mean that it is the common Reality shared by all sentient beings. According to him, each sentient being has its own true nature (shixing 實性), namely, Reality. Because the true natures of all sentient beings are similar and indistinguishable (tongfen 同分; sabhāgatā), they can be discussed generally as productive power/constant transformation. ${ }^{454}$ This idea in Weishi lun is a continuation of Xiong's clarification of the concept of productive power/constant transformation in his 1926 Weishixue gailun, where he made it clear that each sentient being has its own productive power/constant transformation rather than sharing the same origin (tong yuan 同源) with others

454 Xiong, Weishi lun, p. 542. 
(at the time, he considered productive power/constant transformation to be merely conventional Reality rather than ontological Reality). ${ }^{455}$ Also, this idea is rooted in Xiong's belief, as shown in his 1923 Weishixue gailun, that each sentient being possesses its own eight kinds of consciousness and thus has its own "universe" (as the manifestation of its consciousness). According to this 1923 work, the consciousnesses of sentient beings do not enter one another; yet each extends over the whole experiential realm (fajie 法界; dharma-dhātu). This is likened to the way that each beam of light from many lamps extends fully over the same locus but they do not obstruct one another. Xiong called this feature of consciousness "being intermeshed everywhere" (jiaobian 交遍) and used it as a point by which to disprove the view that sentient beings share a common origin or universe. ${ }^{456}$ Therefore, when Xiong talked about Reality and Function in the Weishi lun, he actually meant the Reality and the "phenomenal universe" of each sentient being rather than a common Reality and a common universe shared by all sentient beings.

According to Gao Zanfei in Zun wen lu, in the summer of 1927,457 Xiong clearly expressed that he no longer opposed the view that sentient beings have the same origin, insisting that there is only one Reality shared by all sentient beings:

\section{吾舊宗護法唯識, 則以實體爲交遍，而非是一體。由今思之，此不應 理。只是一體，哪得多元？吾今者仍持同源說也。458}

Previously, I followed Dharmapāla's doctrine of "nothing but

\footnotetext{
455 Xiong, Weishixue gailun (1926), p. 460. It seems that here Xiong identified the concept of "origin" (yuan 源) with the concept of Reality. Also, in a later writing he agreed that in Chinese philosophy, the terms bengen 本根 and benyuan 本原, both meaning "origin", are used to denote Reality. See Xiong, "Yu Zhangjun” 與張君 (To Mister Zhang), in Shili lunxue yu jilüe, p. 228.

456 Xiong, Weishixue gailun (1923), pp. 49-50. I adopted Makeham's translation of the term jiaobian 交遍. See his New Treatise on the Uniqueness of Consciousness, p. 116.

457 In fact, Gao did not directly say "1927" but stated that: "[I] followed my teacher [Xiong] south in the summer vacation, and lived at Faxiang Temple, West Lake, Hangzhou” (暑假隨師南下, 寓杭州 西湖法相寺). Also, according to Gao, Xiong was sick at that time. See Xiong, Zun wen lu, p. 569. However, as related in the "Appendix" attached to Chapter Three, it was in 1927 that Xiong went to Hangzhou from Nanjing to continue his recuperation.

458 Ibid.
} 
consciousness", and so I believed that the Realities [of sentient beings] are intermeshed everywhere rather than being the same one. From my present perspective, this does not accord with reason. [They] are simply the same Reality. How can there be multiple origins? Thus, now I hold the view that [sentient beings] share the same origin.

To corroborate his view that all sentient beings share a common origin or Reality, Xiong resorted to the passage at the beginning of Wang Yangming's "Daxue wen" 《大學》問 (Questions about the Great Learning). ${ }^{459}$ In that passage, Wang claimed that the "benevolence" (ren 仁) inherent in one's mind forms one body (yiti 一體) with the myriad things in the world. ${ }^{460}$ In fact, as Chen Lai explains, here "benevolence's forming one body with the myriad things" is expressed mainly from the subjective rather than the objective aspect. That is to say, it is an ideal state of our mind that we aim to achieve, but it does not suggest that benevolence is the ontological Reality of the myriad things. Indeed, benevolence in that passage was presented simply as the intrinsic reality of the human mind. ${ }^{461}$ Xiong, however, understood Wang to mean that benevolence is the shared origin of the myriad things, ignoring the difference between his own and Wang's accounts. ${ }^{462}$ Above all, by quoting and interpreting Wang's passage, Xiong reinforced his view that all things in the phenomenal world, including sentient beings, share the same origin or Reality.

In his 1932 Xin weishi lun, Xiong clearly maintained that there is only one productive power, as the common Reality of the myriad things in the phenomenal universe:

\footnotetext{
459 See ibid.

460 Wang Yangming 王陽明, “Daxue wen”《大學》問 (Questions about the Great Learning), in Wang Yangming quanji 王陽明全集 (Complete works of Wang Yangming), Shanghai: Shanghai guji chubanshe, 1992, vol. B, p. 968.

461 See Chen Lai, Renxue bentilun 仁學本體論 (Benevolence-based ontology), Beijing: Sanlian shudian, 2014, pp. 288-291.

${ }^{462}$ See Xiong, Zun wen lu, p. 569.
} 
蓋以爲功能者, 即宇宙生生不容已之大流。言大流者, 顯非個別物故。…… 得之以成天, 地得之以成地, 人得之以成人, 物得之以成物。……故知 功能無差別, 方乃遍萬有而統爲其體, 非是各別多能, 別與一一物各 自爲體。

I maintain that productive power is the great flow of the universe's ceaseless generation. To say [productive power is] a "great flow" is to highlight that [it] is not an individual thing. ... Heaven attains it and then becomes heaven; earth attains it and then becomes earth; humans attain it and then become humans; and things attain it and then become things. ... Hence, it is understood that it is only by virtue of having no differentiations that productive power is able to permeate the myriad existents and be the Reality of each and every one of them. It is not the case that [there are] many individual productive powers separately as the Reality of each individual thing. 463

Obviously, the "universe" in this statement is a term that refers to the totality of all sentient and insentient beings rather than a general name for the multitudinous "universes" generated by the consciousnesses of multitudinous sentient beings. For Xiong, the universe ceaselessly generates, and productive power refers to the whole process of this ceaseless generation, or the entirety of the universe. He believed that all things in this universe, including humans (as a group of sentient beings), become what they are by means of productive power, which indicates that productive power is the common origin, or Reality, of those things. What Xiong meant here is that each individual thing possesses the entire productive power, rather than that all things together as a composite take productive power as their Reality.

Why, then, did Xiong change his view about whether or not sentient beings share the same Reality/origin? One reason is that he changed his understanding of

\footnotetext{
463 Xiong, Xin weishi lun (wenyanwen ben, 1932), p. 58; Makeham (trans. and annot.), New Treatise on the Uniqueness of Consciousness, pp. 133-134, mod.
} 
the proposition that "sentient beings share the same origin". According to Xiong's statement recorded in Zun wen $l u$, he previously understood this proposition to mean that, outside the myriad things, there is additionally a common origin that is the Reality of the universe from which everything is derived. For Xiong, this is like numerous floating bubbles ( $f$ 'ou $^{\prime}$ 浮漚) arising from the sea: derived from the seawater, these bubbles are not real entities but temporarily and illusorily appear by relying externally on the seawater. As such, Xiong reasoned, one's life would not be replete in itself and sufficient in itself ( $z i j u z i z u$ 自具自足), and so he initially rejected the idea that sentient beings share the same origin. ${ }^{464}$

According to Xiong, he later changed this understanding of the proposition that "sentient beings share the same origin". Instead, he took this proposition to mean that, although there is a common origin shared by the myriad things, it is not something external to, or independent of, the myriad things; it permeates the myriad things as their Reality, and everything becomes itself by depending on this Reality. In order to make his meaning comprehensible, Xiong still compared the common origin and the myriad things to the sea and its bubbles, only he reinterpreted the relationship between the sea and its bubbles as: if we are not attached to the image of the bubbles, then we will see clearly that the innumerable bubbles in their entirety are indeed the seawater. As such, one is actually selforiginated (zi ben zi gen 自本自根) for there is nothing "external" to rely on. ${ }^{465}$ This is why Xiong no longer opposed the view that sentient beings have the same origin. Accordingly, whether the proposition that "sentient beings share the same origin" implies that the common origin is external to or independent of the myriad things was a crucial factor in Xiong's decision to decide of whether or not to support it.

Another reason for Xiong's change of view about whether sentient beings share the same Reality is that he changed his attitude towards the Buddhist idea of

\footnotetext{
464 Xiong, Zun wen lu, p. 570.

465 Ibid., pp. 570-571.
} 
transmigration. As the contemporary scholar Guo Meihua 郭美華 notes, Xiong's insistence that each sentient being has its own productive power, that is, origin, or Reality, was based on Xiong's belief in the Buddhist idea of transmigration, which expresses that each sentient being has its own spirit (linghun 靈魂, or shenshi 神 識) that is reincarnated and dies without end. ${ }^{466}$ Yet, as recorded in Zun wen lu, because the idea of transmigration contradicts the biological phenomenon of "regeneration" (fusheng 復生) - that is, as for some living beings, if they are cut into several sections, then each of those sections will become an independent living being - by 1926 or early 1927 Xiong no longer believed in this idea. As a result, he abandoned his view that each sentient being has its own Reality or origin. ${ }^{467}$

In addition to the above two reasons, there is also a factor that perhaps contributed to the change in Xiong's thought concerning whether or not sentient beings share the same Reality. That is, Xiong deviated from the Yogācāra concept of “nothing but consciousness" (weishi 唯識; vijñaptimatra) to develop a new understanding of the term weishi.

As introduced in Chapter Two, the concept of "nothing but consciousness" in Yogācāra philosophy means that what appears to us is constructed, projected, and interpreted by our consciousness, and thus nothing in the phenomenal world is beyond the realm of the activities of consciousness. Since each sentient being has its own consciousness, it naturally has its own "phenomenal world", which is constructed, projected, and interpreted by its own consciousness. As mentioned above, it is because he followed this idea in his 1923 Weishixue gailun that Xiong insisted that sentient beings do not share the same origin or universe.

Xiong appears not to have deviated from the Yogācāra idea of "nothing but consciousness" in either the 1923 and the 1926 versions of Weishixue gailun or the Weishi lun. In the 1932 Xin weishi lun, however, he changed his understanding of the

466 See Guo Meihua 郭美華, Xiong Shili bentilun zhexue yanjiu 熊十力本體論哲學研究 (A study on Xiong Shili's ontological philosophy), Chengdu: Ba Shu shushe, 2004, pp. 51-52.

467 Xiong, Zun wen lu, pp. 566-568. 
term weishi:

唯識爲言, 但遮外境, 不謂境無, 以境與識同體不離, 故言唯識。唯 者特殊義，非唯獨義。識能了境，力用殊特，說識名唯，義亦攝境。 豈言唯識, 便謂境無?

The term weishi is said to refute only [the presumption that] external objects [exist independently of consciousness] and does not mean that cognitive objects do not exist. Because cognitive objects and consciousness are the same body and are not separate, it is said to be "weishi". The character wei 唯 means "unique" rather than "only/solely". Consciousness is able to discern cognitive objects; its ability and function are unique. In referring to consciousness and terming it "unique", the referent also includes cognitive objects. How could one talk of weishi and then say that cognitive objects do not exist? ${ }^{468}$

According to Makeham, the term wei 唯 (mātra) in such Sanskrit terms as vijñaptimātra (weishi 唯識; consciousness only, or nothing but consciousness) or cittamātra (weixin 唯心; mind only, or nothing but mind) means "only", "nothing but", and not "unique".469 Through his own interpretation of the term wei as "unique", Xiong rejected the meaning of weishi (vijñapti-mātra) as presented in Yogācāra philosophy, that is, "nothing but consciousness", or "consciousness only", and reappropriated it to mean "the uniqueness of consciousness". In his view, the term weishi only suggests that cognitive objects are the same body with and not separate from consciousness; it does not indicate that cognitive objects do not exist but are merely those into which consciousness transforms. ${ }^{470}$

\footnotetext{
468 Xiong, Xin weishi lun (wenyanwen ben, 1932), p. 23; Makeham (trans. and annot.), New Treatise on the Uniqueness of Consciousness, p. 53, mod.

469 Makeham (trans. and annot.), New Treatise on the Uniqueness of Consciousness, p. xxxi.

470 It should be noted that for Xiong, cognitive objects and consciousness exist only from the perspective of conventional truth. See, for example, Xiong, Xin weishi lun (wenyanwen ben, 1932), p.
} 
As for why cognitive objects and consciousness are the same body and are not separate, according to Xiong in his 1932 work, the fundamental cause is that they possess the same Reality, rather than that the former is produced by the latter. As he explained, cognitive objects and consciousness are both the flowing movement (liuxing 流行) of Reality, 471 which cannot be separated into two segments. However, because Reality is not unchanging (wanran 頑然), it is illusorily manifested as the aspects of subject (neng 能) - namely, consciousness, that which knows (nengzhi 能知) - and object (suo 所), namely, cognitive objects, that which is known (suozhi 所知). Based on this understanding, Xiong maintained that cognitive objects and consciousness were divided only in terms of their different functions or roles, yet, in fact, there was no demarcation between them. ${ }^{472}$

Since the Yogācāra idea of "nothing but consciousness" is indispensable for Xiong's earlier view that each sentient being has its own "universe" and origin, and since Xiong ceased to hold this thesis and subsequently reconstructed it, his previous objection to the view that sentient beings share the same origin and universe was rendered groundless. ${ }^{473}$ Xiong's reinterpretation of weishi is

33. From the perspective of ultimate truth, neither consciousness nor cognitive objects exist, and there is only ceaseless transformation.

471 In Xiong's philosophy, "flowing movement" (liuxing 流行) refers to the transformation of phenomena, that is, the Function of Reality.

472 Ibid., pp. 22-23.

473 In his 1932 work, Xiong still stated that one's "universe" does not obstruct or enter others' "universes" but extends over the same place over which others' "universes" extend. Ibid., p. 50. This could easily be mistaken as indicating that he still held the view that sentient beings do not share a common universe or origin. However, this is not the case. As he explained in Zun wen lu, for instance, each person's defiled consciousness (ranshi 染識) - that is, the seventh or self-centred consciousness (manas) - is not connected with others'. In this sense, it is said that everyone has his or her own "universe". Yet, all have the same pure inherent mind (qingjing benxin 清淨本心). From this perspective, there is only one universe. Xiong, Zun wen lu, p. 594. Similarly, according to Xiong in his 1933 “Po 'Po Xin weishi lun'”, sentient beings, in reality, share the same universe. Because their activities (ye 業; karma) and habituated tendencies (xiqi 習氣; vāsanā) are different, however, the shared universe appears different to them. That is to say, what is called one's own "universe" is formed due to one's own activities and habituated tendencies. In fact, all sentient beings have the same inherent nature (benxing 本性), and so they actually share a common universe. Xiong, "Po 'Po Xin weishi lun"” 破《破新唯識論》 (Refutation of the “Refutation of the New Treatise on the 
presented in the first half of his 1932 Xin weishi lun. As introduced previously, according to Xiong, he had completed this part of what was to become the 1932 publication already by early 1927, around the time that he stopped writing the Weishi lun. This means it is possible that Xiong had already started to doubt the Yogācāra concept of "nothing but consciousness" and had developed his new understanding of weishi even before he abandoned the view that sentient beings each have their own origins and "universes". If this were the case, then this doubt and new understanding are likely to have contributed to the change in his view of whether sentient beings have the same origin/Reality.

Xiong's change from considering each sentient being as having its own Reality to believing that all sentient beings share the same Reality is an essential premise on which he developed his philosophy of Reality and Function between the late 1920s and mid-1930s. His new ideas in this period, such as his claim that one person's mind is the mind of any other person and his proposition that all things (including both sentient beings and insentient beings) in the phenomenal world are one body and mutually inclusive, which will be elaborated later in this chapter, are consistent with the view that all sentient beings (and insentient beings) share the same Reality but contradict the view that each sentient being has its own Reality. Thus, the clarification of this change helps us to comprehend more clearly how Xiong understood Reality and Function in the period between the late 1920s and the mid-1930s and what he had developed at this stage. Keeping this background in mind, in what follows, we will examine Xiong's new ideas of Reality and Function in detail.

Uniqueness of Consciousness"), in Xiong Shili quanji, vol. 2, pp. 163-164. Also, as Xiong further explained, to say that there is only one universe is to talk in terms of ultimate truth; to say that everyone has his or her own "universe" is to talk in terms of conventional truth. Ibid., p. 165. 


\subsection{The Development of Xiong's Understanding of Reality}

\subsubsection{Xiong's Identification of the Mind with Reality}

From the late 1920s to the mid-1930s, Xiong still used the concept of productive power, or constant transformation, to refer to Reality. Nevertheless, a significant development in his understanding of Reality is that he identified it with our mind (xin 心). In the opening chapter of his 1932 Xin weishi lun, “Ming zong” 明宗 (Explanation of the thesis), Xiong presented the aim of composing this work as:

\section{今造此論, 爲欲悟諸究玄學者, 令知實體非是離自心外在境界, 及非 知識所行境界, 唯是反求實證相應故。實證即是自己認識自己, 絕無一毫蒙蔽。}

In composing this treatise now, my aim is to awaken those who study the learning that is concerned with profound truth to understand that Reality is not an external perceptual realm detached from one's own mind, nor is it a perceptual realm where knowledge is exerted. This is because it is only by seeking within and truly realising that there is correspondence [with Reality]. "Truly realising" means that one's self recognises one's self, with absolutely nothing concealed. ${ }^{474}$

This statement demonstrates that Xiong's new idea that Reality is not detached from our mind is the main thesis of his 1932 Xin weishi lun. This idea is seemingly consistent with Xiong's previous view that "suchness is not separate from consciousness", which he presented in his 1923 Weishixue gailun as one of the three meanings of the Yogācāra concept of "nothing but consciousness".475 However, as explained in Chapter Two, when Xiong said that suchness, as Reality, was not separate from consciousness, what he meant is that consciousness does not really exist, and suchness, as the only thing that exists, is the true nature of consciousness. Whereas, as the following quotation shows, what Xiong meant in the above-quoted

\footnotetext{
474 Xiong, Xin weishi lun (wenyanwen ben, 1932), p. 10; Makeham (trans. and annot.), New Treatise on the Uniqueness of Consciousness, p. 21, mod.

475 See Xiong, Weishixue gailun (1923), p. 49.
} 
statement is actually that one's own mind is exactly Reality. In addition, since Xiong no longer held the view that each sentient being has its own "universe" and origin and, instead, maintained that all sentient beings share the same Reality, his idea that Reality is not detached from an individual's mind actually indicates that all individuals' minds are the same mind. Indeed, he clearly stated:

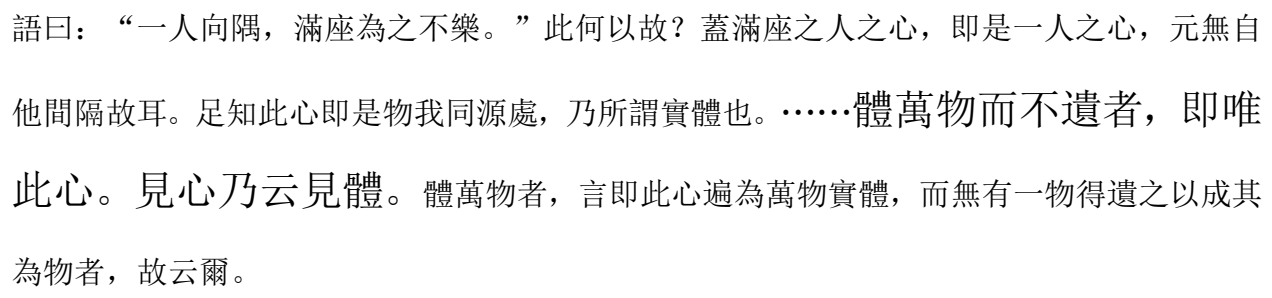

There is a saying: "[If] one person faces a corner, then all the other people present will be unhappy because of this." What is the reason for this? It is because the minds of all the people present are precisely the mind of that one person. This is simply because there has never been a separation of self and other. This suffices for us to understand that this mind is exactly the common source of things and self, that is, what is said to be Reality. ... It is this mind alone that embodies the myriad things, omitting nothing. "Seeing the mind" amounts to saying "seeing Reality". "To embody the myriad things" is saying that everywhere this mind is the Reality of everything and that there is not a single thing that can be what it is without it; hence it is said. ${ }^{476}$

This explicitly shows Xiong's view that one person's mind is actually the mind of any other person - in other words, all humans share the same mind - and that this shared mind is the common Reality of the myriad things, including all sentient and insentient beings in the phenomenal universe. Thus, by returning to one's own mind, one is able to discern the common Reality of all things.

How, then, did Xiong understand the mind as Reality? When he said that the mind is Reality, this mind does not refer to the consciousness that grasps cognitive

\footnotetext{
476 Xiong, Xin weishi lun (wenyanwen ben, 1932), pp. 10-11; Makeham (trans. and annot.), New
} Treatise on the Uniqueness of Consciousness, pp. 22-23, mod. 
objects (qu jing zhi shi 取境之識). Indeed, he differentiated the mind as Reality and the consciousness that grasps cognitive objects, and he called the former "the real mind" (zhenxin 真心) and the latter “false consciousness” (wangshi 妄識):

妄識亦依真心故有, 而實乘真, 識者, 依作用得名。以作用幻現而無自體故, 又雜 習染故, 所以說之為妄。夫用依體起, 故說妄識依真心故有。然用之起也, 既不能無習染之 雜, 故至乘其真, 而有妄執外境之处。證真則了諳幻, 故應說諳是空。真心依本體 得名。見體, 則可了知用之刹那幻現, 本無實法可得; 至習染無根, 元為虛註。然不見體者, 則直以作用之與習染夾雜流行者認為實在, 此過之大也。

Similarly, false consciousness exists by virtue of relying on the real mind, yet it is actually at odds with what is real. Consciousness gets its name from its function. Because its function illusorily appears and does not have self-nature, and also because it is intermixed with habitual defilements, it is said to be false. Function arises by relying on its reality. Thus, it is said that false consciousness exists by virtue of relying on the real mind. However, when the function [of consciousness] arises, since it must be intermixed with habitual defilements, it is utterly at odds with what is real, and so there is the error of false attachment to external objects. Having realised the real [mind], one will know that consciousness is illusory. Hence, it should be said that consciousness is empty. The real mind gets its name on the basis of Reality. Having seen Reality, one can then know that the function [of consciousness] illusorily appears momentarily, and it is fundamentally devoid of real dharmas. As for habitual defilements' having no root, they have always been a matter of deception. However, those who do not see Reality simply take the flowing movement of the function's admixture with habitual defilements to be real. This is a great mistake. ${ }^{477}$

In Xiong's view, the consciousness that grasps cognitive objects, which is what he called "false consciousness", is devoid of self-nature and is thus empty. That which

477 Xiong, Xin weishi lun (wenyanwen ben, 1932), pp. 13-14; Makeham (trans. and annot.), New Treatise on the Uniqueness of Consciousness, p. 29, mod. 
underlies its illusory appearance is its reality, or what Xiong called "the real mind". Unlike false consciousness, the real mind is neither intermixed with habitual defilements (xiran 習染) nor attached to external objects. Only this real mind is the Reality of the universe, and the false consciousness is merely its Function.

Xiong's differentiation between the real mind and the false consciousness is clearly isomorphic with the "two aspects of the one mind" presented in the Dasheng qi xin lun. As introduced in Chapters One and Two, the Dasheng qi xin lun presents the mind of sentient beings as having two aspects. The first is the aspect as suchness, which refers to the inherent nature of the mind. The second is the aspect as arising and ceasing, which exists depending on the suchness aspect. ${ }^{478}$ As for these two aspects, according to the Dasheng qi xin lun, suchness, which can be referred to as the real mind (zhenxin 真心), is not concomitant with defiled dharmas (ranfa 染 法); it is free from the various forms of conditioned dharmas since it is detached from the false mind/conceiving (xuwang xinnian 虛妄心念, wangxin 妄心, or wangnian 妄念). In contrast, the false mind, or the mind that arises and ceases, continuously discriminates (fenbie 分別) in successive thought-moments, and it is not concomitant with suchness. ${ }^{479}$ Apparently, the concepts of the "real mind" and the "false consciousness" in Xiong's statement correspond to the "real mind" and the "false mind/conceiving" in the Dasheng qi xin lun, respectively. In fact, elsewhere in his 1932 work, Xiong noted that "false consciousness" is an alternative name for “false mind" (wangxin 妄心). ${ }^{480}$ According to the above, Xiong is very likely to have drawn on the Dasheng qi xin lun for his own differentiation of the mind as Reality and the consciousness that grasps cognitive objects.

Xiong also called the mind as Reality "the inherent mind" (benxin 本心), and

\footnotetext{
478 For an explanation of the "two aspects of the one mind" in the Dasheng qi xin lun, see Makeham, "Xiong Shili's Understanding of the Relationship between the Ontological and the Phenomenal", pp. 213-214, note 13.

479 See Gao, Dasheng qi xin lun jiaoshi, pp. 17, 21-22.

480 Xiong, Xin weishi lun (wenyanwen ben, 1932), p. 104.
} 
believed that everyone inherently possesses it but may not be aware of it:

本心者, 生生不息的實體也, 是人之所以生之理也, 是人之一身之主 也。人人固有之，而不能自發見之。 481

The inherent mind is the Reality that ceaselessly generates, the principle by virtue of which humans live, and the ruler of the human body. Everyone inherently possesses it yet cannot discern it spontaneously.

Even though one might fail to realise it spontaneously, the inherent mind is one's self-reflection, and under no circumstances could it "be transformed into material form" (wuzhi hua 物質化):

人人隱微間有個自鑒之明, 不可欺瞞者, 即本心也。只此是人生所固 有的神明而不曾物質化的, 故說為本體。

When people are in hidden places, they have the clarity of selfreflection that cannot be deceived. 482 This is the inherent mind. This alone is the numinous clarity that humans possess innately and which has never been transformed into material form. Hence, it is said to be Reality. 483

Elsewhere in his 1932 work, Xiong stated that the reason the mind can be said to be Reality was precisely because it cannot be transformed into material form. However, he also said that if one is mired in material desire and cannot extricate oneself from it, meaning that one is completely transformed by things, then it seems as if one has never possessed the mind and already lost one's intrinsic Reality (guyoude benti 固有的本體). ${ }^{484}$ Accordingly, Xiong's statement that "the inherent

\footnotetext{
481 Xiong, Zun wen lu, p. 609.

482 As Makeham points out, this is the notion of vigilance in solitude (shendu 慎獨). Makeham (trans. and annot.), New Treatise on the Uniqueness of Consciousness, p. 57, note 77.

483 Xiong, Xin weishi lun (wenyanwen ben, 1932), p. 25; Makeham (trans. and annot.), New Treatise on the Uniqueness of Consciousness, p. 57, mod.

484 Xiong, Xin weishi lun (wenyanwen ben, 1932), p. 11.
} 
mind has never been transformed into material form" in the above quotation might be taken to mean that the inherent mind transcends the selfish desire for things, although it can be obscured by selfish desires. As for Xiong's depiction of the inherent mind as "the clarity of self-reflection (zijian zhi ming 自鑒之明) that cannot be deceived", there is a passage in his later writing that explains it:

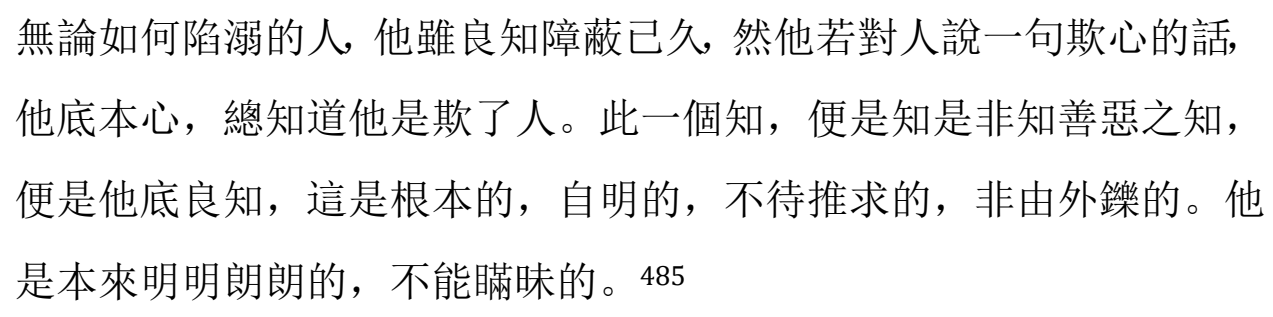

No matter how much one is mired in [the selfish desire for things], although one's innate moral knowledge has been blocked for a long time, if one utters a falsehood to another person, then one's inherent mind will ultimately know that one has deceived that other person. This "knowledge" is precisely the knowledge of right and wrong, and of good and evil; it is exactly one's innate moral knowledge. It is fundamental, self-evident, does not need to be inquired into, and is not permeated from outside. It is inherently luminous and cannot be hoodwinked.

By referring to Wang Yangming's concept of "innate moral knowledge",486 Xiong presented the inherent mind as something that intrinsically possesses the knowledge of right and wrong and of good and evil. It is precisely because of this knowledge that one's inherent mind takes on the role of self-reflection. This passage shows why Xiong referred to the inherent mind as "the clarity of selfreflection that cannot be deceived".

In fact, both "the inherent mind" and "innate moral knowledge" are key concepts in the Neo-Confucian School of Mind and can be traced back to Mengzi 孟

\footnotetext{
485 Xiong, "Yu youren" 與友人 (To a friend), in Shili lunxue yu jilüe, p. 319.

486 According to the context of the quoted passage, the concept of "innate moral knowledge" (liangzhi 良知) in that passage was borrowed from Wang Yangming's philosophy. See ibid.
} 
子 (The book of Mencius), a record of Mencius' (Mengzi 孟子, 372-289 BC?) sayings and dialogues that, according to Wing-tsit Chan, was in all probability compiled by Mencius' pupils after his death. ${ }^{487}$ In Mengzi, Mencius used the term benxin 本心 to refer to one's innate conscience or moral nature, ${ }^{488}$ and presented liangzhi 良知 as something that is inherently possessed by humans and which “knows [what is morally right] without thinking” (bu lü er zhi 不慮而知).489 By inheriting Mencius' thought, Lu Jiuyuan presented "the inherent mind" as a moral principle or instinct that is intrinsic to everyone's mind, and he identified it with Mencius' notion of liangzhi. By appropriating Mencius' term liangzhi, and based on Lu Jiuyuan's idea of the inherent mind, Wang Yangming further presented his own concept of "innate moral knowledge". For Wang, "innate moral knowledge" is not only the inherent moral nature and moral knowledge that everyone possesses but is also the Reality of the universe. ${ }^{490}$ Xiong's understanding of the inherent mind and innate moral knowledge obviously has a connection with this line of thought.

Moreover, like Wang Yangming, Xiong took innate moral knowledge directly to be Reality. According to Zhang Limin in the Zun wen lu, by interpreting Wang

487 Chan, A Source Book in Chinese Philosophy, p. 51, note 15.

488 See Mengzi 孟子, “Gaozi zhangju, shang” 告子章句上 (The chapter of “Gaozi”, A), in Jiao Xun, Mengzi zhengyi, vol. 23, pp. 6-7. Referring to Zhu Xi's interpretation, Wing-tsit Chan noted that the "benxin" in "Gaozi zhangju, shang" refers to the original mind of shame and dislike. Chan, A Source Book in Chinese Philosophy, p. 58, note 41. For a further discussion of Mencius' usage of the term benxin, see Huang Lianzhong 黃連忠, “Huineng yu Wang Yangming benxin sixiang de shijian jinlu yu quanshi fangfa zhi lunxi” 惠能與王陽明本心思想的實踐進路與詮釋方法之論析 (A discussion and analysis of the practical approach to and the interpretative method for Huineng's and Wang Yangming's philosophy of "inherent mind"), Disanjie Zhongguo wenzhe zhi dangdai quanshi xueshu yantaohui huiqian lunwenji 第三屆中國文哲之當代詮釋學術研討會會前論文集 (The proceedings published before the third Academic Conference on Contemporary Interpretation of Chinese Literature and Philosophy), Guoli Taibei daxue, 2007, p. 289.

489 See Mengzi, “Jin xin zhangju, shang”, p. 13.

490 See Huang Lianzhong, "Huineng yu Wang Yangming benxin sixiang de shijian jinlu yu quanshi fangfa zhi lunxi”, pp. 294-296; Lai Yonghai 賴永海, “Foxing, benxin, liangzhi: Lu Wang xinxue yu foxue” 佛性 本心 良知——陸王心學與佛學 (Buddha nature, inherent mind, and innate moral knowledge: Lu Jiuyuan and Wang Yangming's philosophy of mind and Buddhist learning), available at: http://www.gming.org/fjrw/jsrw/laiyonghai/40784.html, accessed August 5, 2018. 
Yangming's concept of "innate moral knowledge", Xiong maintained that that by which we can realise Reality is our innate moral knowledge, which is precisely Reality:

證會者, 蓋吾之良知, 即是實體。良知畑然自知, 便云證會。此知無 分別相，不於實體作外想故，所知能知是一事而不可分故，故陽明指 良知爲實體, 此體是自明的故。491

That which realises [Reality] is our innate moral knowledge, which is precisely Reality. Innate moral knowledge clearly cognises itself, and this is said to be "realisation". This cognition does not have the characteristic of constructed distinctions, because it does not regard Reality as something external, and because that which is cognised and that which cognises are one and the same thing so that they cannot be divided. Therefore, Wang Yangming regarded innate moral knowledge as Reality, because this Reality is self-evident.

As we can see, Xiong believed that our innate moral knowledge is that by which we can realise Reality. For him, since Reality is self-evident - that is to say, what realises Reality is Reality itself - innate moral knowledge is precisely Reality. Based on this understanding, Xiong described the realisation of Reality by innate moral knowledge as an immediate realisation without the constructed distinction of subject and object.

Xiong also expressed his above view of Reality - that which realises Reality is precisely Reality itself - by means of the concept of “wisdom" ( $z h i$ 智) or "luminous wisdom” (mingzhi 明智):492

須知本體不能看作外面的物事, 只可在你本心之明處撲着他。本心之明, 即謂明智。又復當知, 本心即明, 而言本心之明者, 因說話要用個主詞故。……知本體的

\footnotetext{
491 Xiong, Zun wen lu, p. 596.

492 According to Xiong, “wisdom" (zhi 智) is an abbreviation for “luminous wisdom" (mingzhi 明 智). Ibid., p. 597.
} 
是智, 而智還即是本體。 493

It should be understood that Reality cannot be regarded as an external thing; it can be obtained only at the luminous place in your inherent mind. The "inherent mind's luminosity" refers to "luminous wisdom". It should also be understood that the inherent mind is luminous. As for why I speak of the "inherent mind's luminosity", this is because a subject term is needed in an utterance. ... That which cognises Reality is wisdom, and wisdom, in turn, is precisely Reality.

智義云者, 自性覺故, 本無倚故。吾人反觀, 畑然一念明覺, 正是自性呈露, 故 曰自性覺。實則覺即自性, 特累而成詞耳。又自性一詞, 乃實體之異語。賅宇宙萬有而言其 本原, 曰實體。攰就吾人當躬而言其本原, 曰自性。從言雖異, 所目非二故。無倚者, 此覺 不倚感官經驗, 亦復不倚推論故。

This is because the meaning of "wisdom" is "the awareness of selfnature", and because it inherently relies on nothing. ${ }^{494}$ When we reflect within, brilliantly, in a thought-moment, there is clear awareness. This precisely is the manifestation of self-nature. Hence, it is said, "the awareness of self-nature". In fact, awareness is self-nature. It is simply that by joining together [the two words, "awareness" and "self-nature"], the phrase ["awareness of self-nature"] is formed. Moreover, the word "self-nature" is a different term for Reality. If we include the myriad existences in the universe and refer to their origin, then it is called Reality. If we refer strictly to the origin of ourselves, then it is called "self-nature". This is because although verbally they are different, what they refer to are the same. As for "relying on nothing", this is because this awareness does not rely on sensory experience, nor does it rely on logical inference. ${ }^{495}$

493 Ibid., p. 598.

494 This passage is part of the answer to the question of "how are wisdom (zhi 智; jñanna) and discernment (hui 慧; prajña) distinguished?", and so it begins with “this is because ...”. See Xiong, Xin weishi lun (wenyanwen ben, 1932), p. 10.

495 Ibid.; Makeham (trans. and annot.), New Treatise on the Uniqueness of Consciousness, pp. 21-22, 
According to Xiong's two statements above, so-called wisdom is that which realises Reality. It refers to the "luminosity" (ming 明) of our inherent mind (Reality) or the “awareness” (jue 覺) of our self-nature (Reality). Since this "awareness" is indeed our self-nature - in other words, what our self-nature is aware of is precisely itself - this wisdom is exactly Reality. As for the realisation of Reality by wisdom, according to Xiong, since this realisation is devoid of such constructed distinctions as subject (neng 能) and object (suo 所), internal and external, and sameness and difference, it is nominally posited as “one’s self recognising one's self” (自己認識自 己).496

This view that our innate moral knowledge, or wisdom, 497 is that which realises Reality and, at the same time, is itself Reality, is strongly reminiscent of the concept of "wisdom" (zhi 智; jñāna) as presented in Yogācāra philosophy. As Makeham explains, in Yogācāra soteriology, it is by transforming the consciousnesses into "direct cognitions" that the eight consciousnesses cease and one attains non-conceptual wisdom. When all the seeds in the eighth consciousness are transformed into pure, undefiled seeds, one attains "perfect mirror wisdom" (大 圓鏡智; mahādarśa-jñāna) enabling direct, unmediated cognition of things just as they are. Xiong similarly described wisdom as direct, unmediated cognition of one's inherent nature that is at the same time Reality. ${ }^{498}$ Indeed, in his 1933 writing, Xiong stated that what he termed "one's self recognising one's self" was based exactly on the Yogācāra idea of the perception of suchness by true insight (zhengzhi yuan ru 正智緣如) and was an explanation of the latter. From his perspective, true insight - the realisation of suchness when there is no attachment to self or attachment to phenomena - and suchness are nominally designated as the perceiver and that which is perceived. Yet, in fact, there is no differentiation of

mod.

496 Xiong, Xin weishi lun (wenyanwen ben, 1932), p. 11.

497 Indeed, Xiong identified the concept of innate moral knowledge with the concept of wisdom. See Xiong, Zun wen lu, p. 598.

498 Makeham (trans. and annot.), New Treatise on the Uniqueness of Consciousness, p. xxv. 
subject and object: true insight is precisely suchness and what it perceives is nothing but itself. ${ }^{499}$ This evidences that Xiong's understanding of "wisdom" and "innate moral knowledge" has its roots in Yogācāra Buddhism, although his view that the "wisdom"/ "innate moral knowledge" is inherent in our mind is inconsistent with Yogācāra philosophy, as I explain below.

As we have seen, in the period between the late 1920s and the mid-1930s, through elaborating on such concepts as the inherent mind, innate moral knowledge, and wisdom, Xiong presented Reality as something that is intrinsic to our mind. As such, for realising Reality, what we need to do is only seeking within, returning to our own mind. Also, since Reality is self-realised, which means that what is able to realise Reality is precisely Reality itself, a key approach to realising it for us is maintaining our inherent mind/innate moral knowledge/wisdom.

Xiong's identification of Reality with our inherent mind/innate moral knowledge/wisdom appears to have been a response to the disputes on whether the mind of sentient beings is inherently enlightened. As introduced in Chapter One, whether the buddha-nature is acquired or is an inherent nature possessed by all sentient beings - that is, whether the mind of sentient beings is inherently enlightened - is an old issue in Chinese Buddhist history. This issue can be related to the movement to recover "genuine" Buddhism, which occurred in the early decades of the twentieth century and which underscores an antagonism between the Dharmapāla-Xuanzang tradition of Yogācāra and the Dasheng qi xin lun. In Yogācāra Buddhism, the mind of sentient beings belongs to the phenomenal realm, while suchness has nothing to do with phenomenal arising and ceasing. This means that the mind is not inherently enlightened. By contrast, the Dasheng qi xin lun, by presenting suchness as the inherent nature of the mind of sentient beings, insists that the mind of sentient beings is inherently awakened. Xiong's presentation of Reality as something intrinsic to our mind means that he considered our mind to

499 Xiong, “Po 'Po Xin weishi lun'”, p. 174. 
be inherently awakened. This shows his support for the Dasheng qi xin lun, as well as his further deviation from Yogācāra philosophy, in the period between the late 1920s and the mid-1930s.

\subsubsection{Simultaneous Transformation and Constancy as a Characteristic of Reality}

As related in Chapter One, the issue of whether the mind of sentient beings is inherently enlightened is related to the issue of whether Reality is quiescent or active - an important issue in the movement to recover "genuine" Buddhism and its related debates. To claim that Reality is quiescent is to claim that it is unconditioned, inactive, and has nothing to do with phenomenal activities; to say it is active is to say that it is the ontological ground for the phenomenal world and is associated with the generation of phenomena. As discussed earlier in this thesis, in Yogācāra philosophy, it is because suchness is quiescent such that it has nothing to do with phenomenal activities, yet our mind belongs to the phenomenal realm but is not immediately connected to suchness (we have to do certain practices in order to recognise suchness), that our mind is not considered to be inherently enlightened. Whereas, by presenting suchness as the ground on which the phenomenal world is generated, and presenting it and phenomenal activities as two kinds of manifestation of sentient beings' mind, the Dasheng qi xin lun shows that the mind of sentient beings is inherently awakened.

At the same time that Xiong responded to the question of whether the mind of sentient beings is inherently awakened, he also responded to the debates on whether Reality is quiescent or active. Xiong's thought on this issue changed twice between the early 1920s and mid-1930s. As Chapters Two and Three have shown, in both the 1923 and the 1926 versions of his Weishixue gailun, Xiong followed Yogācāra philosophy to consider suchness, i.e., Reality (or to be precise, ontological Reality), as an unconditioned dharma that is constant, not subject to arising, changing, or ceasing, and that bears no relation to phenomenal activities. Yet in the Weishi lun, he replaced the Yogācāra concept of suchness with his reconstructed 
concept of productive power, or constant transformation, and considered the phenomenal world as the illusory manifestation of productive power/constant transformation. Although he presented productive power as arising and ceasing, or transforming, 500 he did not indicate at that time whether it also has the characteristic of constancy or quiescence. As this section will demonstrate, between the late 1920s and mid-1930s, consistent with his view that Reality is inherent in our mind, Xiong also presented Reality as having an aspect of dynamism. Indeed, in his own words, Reality is both “transforming” (bianyi 變易) and “constant” (buyi 不易). This will be elaborated in what follows.

By resorting to the concepts of “transformation” (bianyi 變易) and “constancy” (buyi 不易) presented in “Yi qian zao du” 易乾鳌度 (Chiselling open the regularity of qian of the apocrypha of Change),501 a text written in the Western Han dynasty (202 BC-8) that explains and develops Zhouyi, ${ }^{502}$ Xiong explicitly expressed his view that Reality is both transforming and constant in his 1932 Xin weishi lun:

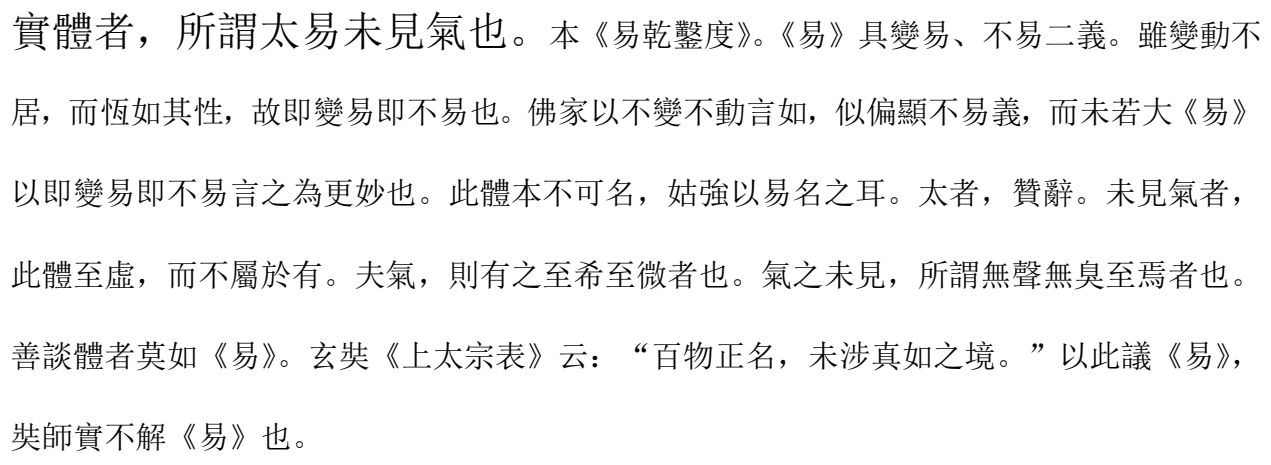

Reality refers to what is called "supreme change before it is manifest as vital stuff". This is based on "Yi qian zao du". Zhouyi includes two meanings: transformation and constancy. Although [change] changes and does not stay, it is

\footnotetext{
500 As for Xiong's view that productive power is arising and ceasing in his Weishi lun, see Xiong, Weishi lun, pp. 545-546.

501 I follow John Makeham's English translation of the title of this text. See his New Treatise on the Uniqueness of Consciousness, p. 50.

502 For an introduction to this text, see Zhu Bokun, Yixue zhexueshi, pp. 159-189.
} 
always like its nature, so transformation is precisely constancy. The Buddhists talk about suchness in terms of "not transforming" and "not moving", which seems to put particular emphasis on showing the sense of "constancy". This is not as sublime as the great Zhouyi, which talks about [Reality] with the sense that "transformation" is precisely "constancy". This Reality is inherently unnameable; tentatively and contrivedly it is named "change". "Supreme" is a laudatory term. "Before it is manifest as vital stuff" means that this Reality is absolutely void and does not belong to the realm of having [defining characteristics], whereas vital stuff is the most silent, the most subtle type of having [defining characteristics]. Before vital stuff has been made manifest, it is said to be absolutely devoid of any sound and odour. As for those who are good at talking about Reality, nothing is comparable to Zhouyi. Xuanzang's "Shang Taizong biao” 上太宗表 (Memorial to the Emperor Taizong 太宗 [r. 626-649]) states: "[Even though] the one hundred things have correct names, this has no bearing on the realm of suchness."503 Discussing Zhouyi in these terms, Master Xuanzang really did not understand it. ${ }^{504}$

The expression, “supreme change before it is manifest as vital stuff” (太易未見氣), and the concepts of "transformation" and "constancy" all originated in the "Yi qian zao du". According to Zhu Bokun, here the "supreme change before it is manifest as vital stuff" refers to the state before vital stuff has come into being. This is a state of "looking without seeing, listening without hearing, and seeking without obtaining" (視之不見, 聽之不聞, 循之不得), or a state in which heaven, earth, and the myriad things have yet to appear. ${ }^{505}$ Xiong's explanations of "before it is manifest as vital stuff” (未見氣) and “before vital stuff has been made manifest” (氣之未見) in the

503 Xuanzang, “Xie Taizong Wen Huangdi zhi Sanzang shengjiao xubiao” 謝太宗文皇帝製三藏聖教 序表 (Memorial to thank Emperor Taizong, whose posthumous title is wen, for writing a preface to the holy teaching of Tripițaka), in Si Shamen Xuanzang shangbiao ji 寺沙門玄奘上表記 (Record of memorials presented by Monk Xuanzang), in the CBETA edition of the Taishō Tripitaka, T52n2119, $0819 \mathrm{~b} 06$.

504 Xiong, Xin weishi lun (wenyanwen ben, 1932), p. 22; Makeham (trans. and annot.), New Treatise on the Uniqueness of Consciousness, pp. 50-51, mod.

505 Zhu Bokun, Yixue zhexueshi, pp. 166-167. 
auto-commentary seem to be consistent with this meaning. As Zhu relates, however, according to the "Yi qian zao du", there is actually a developmental process from the state of supreme change before it is manifest as vital stuff through to the formation of the phenomenal universe.506 In contrast, Xiong's understanding of Reality and Function during the period between the late 1920s and the mid-1930s denies that the phenomenal world and its Reality are two different realms that appear in a chronological sequence. Thus, although Xiong referred to Reality as the "supreme change before it is manifest as vital stuff", he was not really concerned with what this expression indicates in the "Yi qian zao du". According to Xiong's overall understanding of Reality and Function in the 1932 Xin weishi lun (that is, in reality, phenomena are not real but appear due to our false discriminations, and the only thing that truly exists is Reality), what he sought to express by employing this expression is probably the view that Reality is seen when we are free from attachment to the phenomenal world as real. This view will be discussed in detail later in this chapter.

With respect to the concepts of "transformation" and "constancy" in the "Yi qian zao du", according to Zhu, the former refers to vital stuff, and means that everything is in transformation; the latter refers to the order of heaven and earth, as well as to the social status of individuals, and was employed to demonstrate that the hierarchical order in feudal society is immutable. ${ }^{507}$ By drawing on the sense found in the "Yi Qian zao du", that in constant transformation there is an unchanging order, Xiong expressed his view that although Reality always transforms (as will be shown in section 4.3.1, the transformation of Reality is stated in terms of its illusory manifestation, namely, Function), its inherent nature is constant. In this sense, transformation is indeed constancy.

Since Xiong identified our mind with Reality, his belief that Reality is both transforming and constant is reflected largely in his description of the mind as both

\footnotetext{
506 Ibid., pp. 166-168.

507 Ibid., pp. 164-165.
} 
moving (dong 動) and quiescent (jing 靜). This view of the mind was expressed already in Zun wen lu. For example, Xiong used the term "god-like" (shen 神) - a term he appropriated from Zhou Dunyi's 周敦頣 (1017-1073) writing508 - to describe the simultaneous movement and quiescence of the mind:

至若以神言動靜, ……這動字靜字, 都不含有時空的意義, 更沒有旁底 力使他動靜，他就是自己如此而即動即靜，即靜即動的，所以謂之神。 動以言其非固定的物事, 直是變化不窮。靜以言其極變化不窮, 而又 有則而不可亂也。順自然之則, 而不亂故靜。只此謂之神。這神不是宗教上 底神，蓋即形容吾心之妙而已。509

As for using "god-like" to talk about "movement" and "quiescence", ... neither of the words, "movement" and "quiescence", contains the sense of space-time, nor is there an additional power that makes them move or remain quiescent. It is just the way it is: movement is quiescence, and quiescence is movement. Hence, it is referred to as "god-like". "Movement" is used to explain that it is not a fixed thing, but simply endless change; "quiescence" is used to explain that, although its exhaustive change does not come to an end, it has a rule and so cannot be disturbed. Following a natural rule, it is undisturbed and so it is quiescent. Only this is called "god-like". This is not the god in religion; indeed, it describes the wonderfulness of our mind, and that is all.

For Xiong, our mind is both moving and quiescent: movement is quiescence, and quiescence is movement. To say it moves is not to say that it moves from one place to another after some time, but is to say that it changes ceaselessly; and to say it is quiescent is not to say that it remains still in one place, but is to say that in the

\footnotetext{
508 Zhou Dunyi was a Neo-Confucian in the Northern Song dynasty. His original words are: "Moving without being still and being still without moving characterise things; moving yet not moving, and being still yet being not still, characterise the god-like" (動而無靜, 靜而無動, 物也; 動而無動, 靜 而無靜, 神也). Zhou Dunyi 周敦頣, Zhouzi tong shu 周子通書 (Zhou Dunyi's book on penetrating the Book of Change), Shanghai: Zhonghua shuju, 1927-1936, p. 4. Quoted in Xiong, Zun wen lu, p. 612. 509 Ibid., pp. 612-613.
} 
process of its ceaseless change, there is something constant, that is, a rule by which its change cannot be disturbed. Nevertheless, although Xiong here expresses the view that the mind is both moving and quiescent, it seems from the Zun wen lu that he did not attach much importance to, or further expound on, this idea at that time.

It was not until the 1932 Xin weishi lun that Xiong endorsed this idea and developed it greatly. For example, in the opening chapter in his 1932 work, "Ming zong", Xiong further clarified his view that the mind is simultaneously moving and quiescent: 510

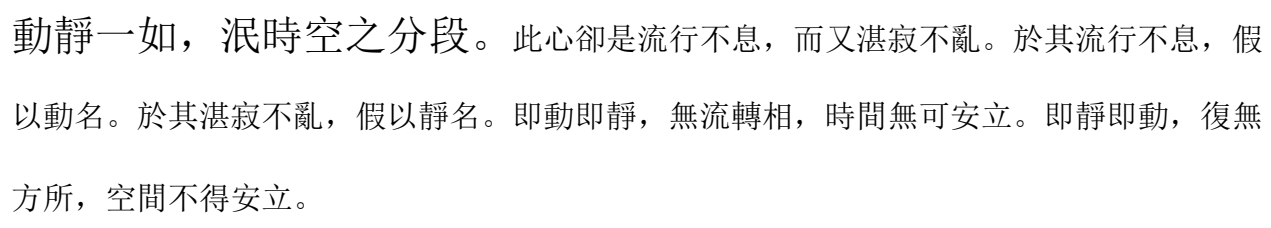

Whether moving or quiescent, [the mind] is as one, eliminating the divisions of time and space. This mind does indeed flow and move ceaselessly, yet it is also profoundly tranquil and undisturbed. In regard to its ceaseless flow and movement, it is nominally termed "moving". In regard to its profound tranquillity and state of being undisturbed, it is nominally termed "quiescent". Movement is precisely quiescence, and there is no characteristic of continuous arising. [As such,] time cannot be established. Quiescence is precisely movement, and there is no place [where the mind stays], either. [As such,] space cannot be established. ${ }^{511}$

Here, the terms "movement" and "quiescence" are used provisionally to describe the two facets of the mind. The former refers to the mind's ceaseless flow and

\footnotetext{
510 Although Xiong himself said that the first half of his 1932 Xin weishi lun had been completed by early 1927, just as Li Qingliang points out, after Xiong became acquainted with Ma Yifu in 1929, he went back to this part of writing and modified it based on Ma's idea of "seeing constancy in transformation" (bian zhong jian chang 變中見常). See Li Qingliang, “Ma Yifu dui Xiong Shili Xin weishi lun qianbanbu zhi yingxiang” 馬一浮對熊十力《新唯識論》前半部之影響 (Ma Yifu's influence on the first half of Xiong Shili's New Treatise on the Uniqueness of Consciousness), Hunan shifan daxue shehui kexue xиebao 湖南師範大學社會科學學報, issue 6, 2009, pp. 10-14.

511 Xiong, Xin weishi lun (wenyanwen ben, 1932), p. 11; Makeham (trans. and annot.), New Treatise on the Uniqueness of Consciousness, p. 23, mod.
} 
movement, whereas the latter refers to the mind's profound tranquillity and its state of being undisturbed. Although the mind has two facets, these facets refer to the same mind and are mutually entailing. Again, this division of the mind into two facets resembles the idea of "the two aspects of the one mind" in the Dasheng qi xin lun.

As Li Qingliang points out, Xiong's change from emphasising the transformation of Reality in the Weishi lun to advocating its simultaneous transformation and constancy in the 1932 Xin weishi lun was in all probability influenced by Ma Yifu's perspective. ${ }^{512}$ As recorded in the Yulu leibian 語錄類編 (Classified compilation of the recorded sayings), a collection of Ma Yifu's various sayings compiled by Ma's students, when Ma visited Xiong for the first time in 1929, they talked a great deal about the notions of "constancy" (chang 常) and "transformation” (bian 變). At that time, Xiong still advocated transformation, whereas Ma asserted that we should see constancy in transformation (bian zhong jian chang 變中見常).513 Further, as Li Qingliang demonstrates, in 1930, Ma and Xiong again discussed the issue of whether Reality is transforming or constant through an exchange of letters. In his replies to Xiong's letters, Ma insisted that transformation is not Reality; rather, it is only the attribute (de 德) of Reality. In Ma's view, Reality is constant and tranquil, and should be seen amid transformation. For him, flowing movement (liuxing 流行) is non-shifting (buqian 不遷), and transformation (bianyi 變易) is constancy (buyi 不易). 514 The above shows that during the process of composing his 1932 Xin weishi lun, whether Reality is

\footnotetext{
512 See Li Qingliang, “Lun Ma Yifu dui Xiong Shili Xin weishi lun zhi yingxiang” 論馬一浮對熊十力 《新唯識論》之影響 (A discussion of Ma Yifu's influence on Xiong Shili's New Treatise on the Uniqueness of Consciousness), Taiwan Dongya wenming yanjiu xuekan 臺灣東亞文明研究學刊, vol. 7, issue. 1, June 2010, pp. 201-232. Nevertheless, from Li's perspective, Xiong's view in the Zun wen $l u$ that we can reveal Reality gradually by maintaining and cultivating our inherent mind indicates that Reality itself is ceaselessly transforming. Li's perspective seems to be inappropriate, since "Reality is transforming" and "Reality can be gradually revealed" are indeed two different issues. 513 Ma Yifu 馬一浮, Yulu leibian 語錄類編 (Classified compilation of the recorded sayings), in Ma Yifu ji 馬一浮集 (Collections of Ma Yifu), Hangzhou: Zhejiang guji chubanshe, 1996, vol. 3, p. 1096. 514 See Li Qingliang, “Lun Ma Yifu dui Xiong Shili Xin weishi lun zhi yingxiang”, pp. 209-210.
} 
transforming or constant was an important issue that Xiong discussed with Ma. As for their respective opinions on this issue at that time, Xiong had once believed that Reality is transforming, while Ma held that Reality is constant.

In addition to his discussions with Xiong, Ma also expressed his view on whether Reality is transforming or constant on other occasions. Ma's student Wu Yifeng 烏以風 (1901-1989) recorded in his “Wen xue siji” 問學私記 (Private record of consulting about learning) that Ma had once said that if one regarded transformation as Reality, then one held a distorted view and committed a grave error. To explain this perspective, Ma reiterated that "transformation"/"shift and flow” (qianliu 遷流)/“arising and ceasing” (sheng mie 生滅) is indeed “constancy"/"non-shifting and non-flowing”(bu qianliu 不遷流)/“non-arising and non-ceasing" (bu shengmie 不生滅), and that we should see the latter in the former. According to $\mathrm{Wu}$ Yifeng, Ma's statement was directed to the phenomenon that "among writers of books recently, there are those who take transformation to be Reality” (近人著書有以變易爲本體者). 515 According to Li Qingliang, Ma's statement was made between 1929 and 1933.516 Thus, it was probably to have been aimed at Xiong's thought in the Weishi lun.

In his 1932 Xin weishi lun, Xiong posed a hypothetical criticism of himself for taking "arising and ceasing” (sheng mie 生滅) and "change and movement" (biandong 變動), rather than something that does not arise, cease, change, or move, to be Reality. ${ }^{517}$ As a reply to this assumed criticism, Xiong stated:

汝意將於生滅法外別求不生不滅法，於變動法外別求不變不動法乎?

若爾, 是生滅變動法便離異不生滅不變動法而有自性, 何須安立不生 滅不變動法爲彼實性? 不容有二體性。又實性若唯是頑然不生滅不變動者, 即是空洞無物, 將誰得名諸法實性? ……應知我說生滅即是不生不滅

\footnotetext{
515 Wu Yifeng 烏以風, “Wen xue siji” 問學私記 (Private record of consulting about learning), in $M a$ Yifu ji, vol. 3, p. 1145.

516 Li Qingliang, “Lun Ma Yifu dui Xiong Shili Xin weishi lun zhi yingxiang”, p. 209.

517 See Xiong, Xin weishi lun (wenyanwen ben, 1932), p. 68.
} 


\section{我說變動即是不變不動。}

You mean additionally to seek a dharma that does not arise and does not cease beyond the dharmas of arising and ceasing, additionally to seek a dharma that does not change and does not move beyond the dharmas of change and movement? If this is so, then those dharmas of arising and ceasing, change and movement, would be separate and different from the dharma that does not arise or cease and does not change or move, and they would have self-nature - [so] what need is there to establish a dharma that does not arise or cease and does not change or move as their true nature? There cannot be two Realities. Further, if true nature is nothing but that which intractably neither arises nor ceases, neither changes nor moves, then it is an empty nothing. [As such,] how could it be termed the true nature of the various dharmas? ... It should be understood that I say "arising and ceasing" is precisely "not arising and not ceasing", and that I say "change and movement" is precisely "unchanging and unmoving".518

The dharmas of arising and ceasing, change and movement, refer to conditioned phenomena; the dharma that does not arise, cease, change, or move refers to Reality, suchness, or the true nature of the various phenomena. In Xiong's view, Reality is not something external to the phenomenal realm, but is the true nature of all phenomena, and conditioned phenomena do not have self-nature and are merely that as which Reality illusorily appears to us due to our false discriminations. As such, the phenomenal realm is not different from Reality ontologically, only we need to see constancy in transformation. 519 This also is why Xiong considered Reality to be both transforming and constant: although it appears to be transforming

\footnotetext{
518 Ibid., p. 69; Makeham (trans. and annot.), New Treatise on the Uniqueness of Consciousness, p. 156, mod.

519 On Xiong's understanding of "transformation" and "constancy", see also Makeham, "Xiong Shili's Understanding of the Relationship between the Ontological and the Phenomenal", pp. 214-217; "Xiong Shili on Why Reality Cannot be Sought Independent of Phenomena", pp. 511-513.
} 
incessantly, it is inherently constant. Through presenting that "transformation is precisely constancy" in this statement, Xiong refuted the above-mentioned hypothetical criticism posed by himself, which differentiates transformation and constancy by asserting that he took the former, rather than the latter, to be Reality.

As related above, in the process of composing his 1932 Xin weishi lun, Xiong used to maintain the view that Reality is transforming, but he did not emphasise that it is inherently constant. He discussed his views with Ma, who held that Reality is constant and that we should see constancy in transformation. Yet, it is obvious that in the 1932 work, Xiong had already changed his view and turned to consider Reality as both transforming and constant, or, to be precise, transformation is constancy, and thus demonstrated his view that Reality is inherently constant transformation is only its external manifestation. This change is probably a result of his compromise with Ma and a reflection of his adoption of Ma's perspective.

In sum, in the period between the late 1920s and the mid-1930s, Xiong's perspective on whether Reality is transforming/active or constant/quiescent changed again, and his change from presenting Reality as transforming in the Weishi lun to maintaining that transformation is constancy in the 1932 work largely is a result of Ma Yifu's influence as well as of Xiong's absorption of certain ideas from the "Yi qian zao du" and the Dasheng qi xin lun. By presenting Reality as both transforming and constant, Xiong now endowed Reality with an aspect of dynamism while also highlighting its inherent nature as constant. It is precisely because Reality embraces an aspect of transformation that it is manifested illusorily as the phenomenal world, and it is precisely because Reality is also constant that, although the various dharmas in the phenomenal world arise, cease, change and move, they are always like their unchanging true nature. Thus, Xiong's view of Reality as both transformation and constancy is closely related to his view of Reality (the true nature of phenomena) and Function (the phenomenal world) as non-dual, which will be elaborated in the following section. 


\subsection{The Relationship between Reality and Function}

\subsubsection{It is Precisely Function That is Reality}

Indeed, the transformation of Reality was stated by Xiong with respect to its illusory manifestation, namely, Function; its constancy is stated by him according to its unchanging nature, or Reality itself. Based on his view that Function has no selfnature, and consistent with his assertion that "transformation is precisely constancy", Xiong presented the relationship between Reality and Function as "it is precisely Function that is Reality" - a conspicuous notion in his writings between the late 1920s and mid-1930s. Nevertheless, this notion does not signify that Function is identical to Reality, as it literally means. Rather, as shown in the following, it indicates that because Function is devoid of self-nature, it does not differ from Reality ontologically.

A passage in the 1932 Xin weishi lun reveals clearly what Xiong meant by "it is precisely Function that is Reality", or "transformation is precisely constancy":

應知我說生滅即是不生不滅, 我說變動即是不變不動。何以故？所謂 生滅者, 刹那刹那幻現其相, 都無暫住故。實無有生滅法可得, 便是 不曾生滅。所謂變動者, 刹那刹那幻現其相, 都無暫住故。實無有變 動法可得, 便是不曾變動。然則生即無生, 以生而不有故; 滅即非滅, 以滅而不息故; 變即不變, 以變而恆貞故; 動即不動, 以動而不遷故。 會得時, 於萬象皆見爲真如, 於流行便識得主宰, 於發用自不失靜止。

It should be understood that I say "arising and ceasing" is precisely "not arising and not ceasing", and that I say "change and movement" is precisely "not changing and not moving". For what reason? This is because, instant by instant, so-called "arising and ceasing" illusorily manifests its characteristic, never abiding for a moment. In reality, there does not exist any dharma of arising and ceasing, and so it has never arisen nor ceased. This is because instant by instant, so-called "change and movement" illusorily manifests its characteristic, never abiding for 
a moment. In reality, there does not exist any dharma of change and movement, and so it has never changed or moved. As such, arising is non-arising because arising does not exist; ceasing is non-ceasing because ceasing does not rest; 520 change is unchanging because change is always constant; 521 movement is non-moving because movement does not shift. When this is comprehended, each of the myriad images will be seen to be suchness, the ruler will be discerned among the flowing movement [of phenomena], and, naturally, stillness will not be ignored in activity. ${ }^{522}$

Both "arising and ceasing" and "change and movement" here refer to phenomenal activities, or Function, the illusory manifestation of Reality. Both "neither arising nor ceasing" (busheng bumie 不生不滅) and “neither changing nor moving" (bubian budong 不變不動) refer to the true nature of phenomena, that is, Reality, or suchness. For Xiong, conditioned dharmas cease as soon as they arise, without abiding even temporarily, and so they have never really existed. What we observe to be the arising, ceasing, change, and movement of phenomena are only illusions. In reality, the so-called phenomenal activities are always like their true nature, which does not arise, cease, change, or move. In this sense, transformation is constancy, and Function is Reality. Thus, it is precisely because phenomena do not have self-nature that they do not differ from their Reality.

In his "Po 'Po Xin weishi lun', Xiong further elaborated his above view that Function is not real, but merely the illusory manifestation of Reality, and thus, it

\footnotetext{
520 Just as Makeham notes, ceasing does not rest because there is nothing to rest since nothing arose in the first place. See his New Treatise on the Uniqueness of Consciousness, p. xlvi, note 86.

521 This refers to Xiong's view that although Reality appears always to be transforming, its inherent nature is constant.

522 Xiong, Xin weishi lun (wenyanwen ben, 1932), pp. 69-70; Makeham (trans. and annot.), New Treatise on the Uniqueness of Consciousness, pp. 156-158, mod. In fact, Xiong's interlinear autocommentaries are inserted between these sentences. To make this quotation less lengthy, I included only the sentences in the main text for this passage.
} 
does not differ from Reality:

體不可直揭, 而從其流行強爲擬似。擬似猶言形容。頑空不可謂體, 故必 有用, 假說流行。流行即是用之代詞。流行即體, 元非異體有別實物。流行 者即是本體之流行, 故不可說其異於體而別有實物, 若認流行為有實物者, 便與體對待而成 二片矣, 此不應理。流者不流之流, 萬有波騰而常寂; 行者不行之行, 眾相 森羅而皆空。故乃即用即體, 即轉變即不變, 以此假說功能爲本體。 523

Reality cannot be directly disclosed, and so I contrivedly proposed [something] similar to it in terms of its flowing movement. "Propose [something] similar" is like saying "describe". Complete emptiness cannot be said to be Reality, so [Reality] must have its Function, which is nominally said to be "flowing movement". "Flowing movement" is an alternative term for "Function". Flowing movement is precisely Reality; it has never been the case that different from Reality this is some separate real thing. Flowing movement is the flowing movement of Reality, and so we cannot say that different from Reality there separately is some real thing. If one considers flowing movement to have some real thing [that flows and moves], then [flowing movement] would be opposite to Reality such that the two would become two parts. This does not accord with reason. The flow is the flow of not flowing although the myriad existents [are active like] leaping waves, they are always tranquil; the movement is the movement of not moving although the various [phenomenal] images are arranged together, they are all empty. Hence, it is precisely Function that is Reality, and it is precisely transformation that is constancy. For this reason, I nominally say that productive power is Reality.

According to Xiong, Reality is beyond conceptualisation and thus cannot be revealed directly through linguistic expression. However, given that it must be

523 Xiong, “Po 'Po Xin weishi lun'”, p. 172. 
expressed as Function or flowing movement - otherwise it would be empty - we may as well try to describe it in terms of the latter. This is why Xiong referred to Reality as "productive power" or "constant transformation", a concept he presented from the perspective that dharmas in the phenomenal world arise and cease uninterruptedly. The fundamental reason for Xiong to describe Reality with respect to Function was his belief that the latter discloses the former; although the various phenomena seem to flow and move, they actually are unreal, devoid of self-nature. The real thing behind the illusory phenomenal appearances is the constant, quiescent Reality, which neither flows nor moves. In Makeham's words, "that which ontologically underpins the non-existent phenomenal arising, ceasing, change and movement is the non-individuated inherent nature that itself is non-arising, nonceasing, unchanging and non-moving".524 It is in this sense that Xiong said that it is precisely Function that is Reality, and it is precisely transformation that is constancy.

Xiong also reinforced his view that Function is precisely Reality by analogy with the relation between water and its waves. He compared Reality to water (or the unchanging nature of water) and Function to waves. For Xiong, water manifests itself illusorily as the waves, yet the nature of water, namely, water itself, is always constant. Although the waves appear to arise and cease, they are nothing but water. Thus, by their dependence on water, the waves arise illusorily; it is not that they have a separate self-nature and so differ from water. Through this metaphor, Xiong conveyed the view that Function arises depending on Reality, and because it is devoid of self-nature, it is not different from Reality. As he clearly stated, it was exactly with this understanding that he said that "it is precisely Function that is Reality".525

The metaphor of water and its waves has been widely used to explain the relation between Reality and phenomena in Sinitic Buddhist texts. Among them, the

\footnotetext{
524 Makeham, "Xiong Shili's Critique of Yogācāra Thought in the Context of His Constructive Philosophy", p. 268.

525 Xiong, “Da moujun” 答某君 (Reply to someone), in Shili lunxue yu jilüe, p. 260.
} 
Dasheng qi xin lun is particularly influential. By referring to the case that the waves are generated because of wind blowing, and the inherent nature of seawater wetness (shixing 濕性) - never changes, the Dasheng qi xin lun conveys the idea that, although the luminous intrinsic nature of the mind of sentient beings (suchness, Reality) can be disturbed by ignorance, which leads to the generation of the mind that arises and ceases (phenomenal activities), its inherent nature is unchanging. ${ }^{526}$ Further, as Ng Yu-kwan notes, the metaphor of a massive ocean and its waves was often used to explain the coherent relation between principle (li 理) and events (shi 事) or between ontological substance and phenomena in the works of various Huayan masters, such as Dushun's 杜順 (557-640)527 Huayan wujiao zhiguan 華嚴五教止觀 (Calming and contemplation in the five teachings of Huayan), Fazang's Huayanjing yihai baimen 華嚴經義海百門 (One hundred categories of the many meanings in the Huayan Sutra), and Chengguan's 澄觀 (738-839) ${ }^{528}$ Huayan fajie xuanjing 華嚴法界玄鏡 (The mysterious mirror of the Huayan dharmadhātu). ${ }^{529}$ Xiong's use of the metaphor of water and its waves to illuminate his understanding of the non-dual relation between Reality and phenomenal activities seems to have a connection with such Sinitic Buddhist texts as the Dasheng qi xin lun and certain Huayan texts.

Moreover, Xiong related his idea that Function is precisely Reality to the theory of the two truths. According to him, the things in the phenomenal world are nominally posited to exist according to conventional truth. According to ultimate truth, however, the various phenomena are empty of intrinsic nature and

\footnotetext{
526 Gao, Dasheng qi xin lun jiaoshi, p. 36.

527 Dushun is considered to be the first patriarch of the Huayan school.

528 Chengguan is considered to be the fourth patriarch of the Huayan school.

529 Ng, "Xiong Shili's Metaphysical Theory about the Non-separability of Substance and Function", p. 245 , note 13 . For a detailed introduction to the use of the metaphor of water and its waves by the Huayan school, see Brook Ziporyn, Beyond Oneness and Difference: Li 理 and Coherence in Chinese Buddhist Thought and Its Antecedents, Albany: State University of New York Press, 2013, pp. 235241.
} 
everything manifest before us is nothing but the presentation of Reality. ${ }^{530}$ As Makeham indicates, Xiong might seem to affirm here the Madhyamakan thesis that ultimate and conventional truths essentially are identical. However, Xiong effectively posited Reality as an underlying "locus" on which phenomenal/conventional reality is ontologically grounded. By contrast, a thoroughgoing Madhyamakan perspective would never insist that emptiness underlies the phenomenal because it holds that emptiness is not a real entity but only means that everything in the phenomenal world depends on a network of conditions and is therefore devoid of self-nature. ${ }^{531}$ Indeed, Xiong's understanding of the two truths above seems to be closer to Fazang's use of them in illuminating the doctrine of the conditioned origination from the tathāgatagarbha as presented in the Dasheng qi xin lun. According to Peter N. Gregory, Fazang identified the two aspects of the tathāgatagarbha - its response to conditions (sui yuan 隨緣), which gives rise to all phenomena, and its immutability (bubian 不變), which refers to the fact that it is identical with the dharmakāya (Reality) and therefore remains forever untainted - with the one mind as seen from the point of view of conventional and ultimate truth. ${ }^{532}$ That is to say, from the perspective of conventional truth, tathāgatagarbha responds to conditions to generate phenomena; from the perspective of ultimate truth, it is intrinsically pure and identical with Reality. By referring to the two truths, Fazang expressed the view that the phenomenal and the ontological are the same thing, but seen from different perspectives, with the latter being the unchanging nature of the former. Obviously, this resembles Xiong's reference to the two truths to elucidate his view that Function is precisely Reality. Again, this similarity between Fazang and Xiong indicates that Xiong's view that Function is precisely Reality is associated with Huayan philosophy, for which the Dasheng qi xin lun is an important source.

\footnotetext{
530 Xiong, Xin weishi lun (wenyanwen ben, 1932), pp. 55, 70-71.

531 Makeham, "Xiong Shili's Critique of Yogācāra Thought in the Context of His Constructive Philosophy", p. 269.

532 Gregory, Tsung-mi and the Sinification of Buddhism, p. 158.
} 
Although Xiong proposed that "it is precisely Function that is Reality", he did not mean that Function is identical to Reality. Just as he said: "We should not take the flowing movement [Function] for Reality. Only discerning the ruler amongst the flowing movement is to discern Reality" (不可認取流行以爲體, 唯於流行中識主 宰, 方是識體). 533 That is to say, flowing movement, or Function, cannot be identified with Reality, because the former is illusory and the latter is real. ${ }^{534}$ From what has been demonstrated in this section, we can see that what Xiong meant by "it is precisely Function that is Reality" is actually that phenomenal activities (Function) are devoid of self-nature and thus ontologically are no different from Reality. This can be understood by appropriating the metaphor of the rope and snake, a popular Yogācāra metaphor used to describe the relationship between the three natures of existence and which was also used by Xiong to elucidate the relationship between Reality and Function in his later writings. ${ }^{535}$ In Yogācāra philosophy, rope is compared to the dependent nature of existence, the snake that the rope is mistaken to be is compared to the imaginary nature of existence, and the constituents that make up the rope is compared to the nature of existence being perfectly accomplished, or suchness. ${ }^{536}$ To understand Xiong's thought, here we can simply compare Reality to a rope and Function to the snake that the rope is mistaken to be. Because the snake is not real but only an imaginative construction, it is actually the rope in nature. Similarly, for Xiong, Function is not real but only that as which Reality illusorily appears to us due to our false attachment, so it is not different from Reality at the level of ultimate truth. This is what he meant by "it is precisely Function that is Reality".

\footnotetext{
533 Xiong, “Po 'Po Xin weishi lun'”, p. 184.

534 On this point, also see Xiong, "Da moujun”, pp. 255-256.

535 See, for example, Xiong, Xin weishi lun (yutiwen ben, 1944), p. 80.

536 For an introduction to this Yogācāra metaphor, see Sponberg, "The Trisvabhāva Doctrine in India \& China", pp. 106-108.
} 


\subsubsection{Revealing Reality through Function}

Xiong's proposition that Function is precisely Reality provides him with a basis on which to elucidate his view of revealing Reality through Function. Between the late 1920s and mid-1930s, Xiong emphasised several times that his main goal was to reveal Reality. ${ }^{537}$ For him, since Reality is not something that can be pondered or linguistically expressed, we can only nominally explain it in terms of its flowing movement and reveal it through its Function. 538 It is necessary and possible to reveal Reality through Function precisely because Function does not differ from, yet is also not identical with, Reality:

\section{蓋流行非即是體，而體要非超越流行幺相之外而別爲獨存之死體。…... \\ 體必有用, 亦定不離用。定不離用者, 即定不離流行故。定不離流行, 故乃於流行中識體，是謂 “即用顯體”。539}

Flowing movement is not exactly Reality, yet crucially it is not the case that Reality transcends the illusory appearances of the flowing movement and separately exists as a lifeless Reality. ... Reality must have Function, and it is certainly not apart from Function. The reason why it is certainly not apart from Function is because it is certainly not apart from the flowing movement. Because it is certainly not apart from the flowing movement, Reality is to be discerned amongst the flowing movement. This is called "revealing Reality through Function".

Thus, phenomenal activities - or Function, the flowing movement of Reality should not be identified with Reality, given that they are illusory and thus empty, while Reality is real and cannot be empty. However, as Reality manifests itself as illusory phenomena, and thus is not separate from the latter, it is able to be recognised from the latter. This is what Xiong understood as "revealing Reality

\footnotetext{
537 See, for example, Xiong, Zun wen lu, p. 568; Xin weishi lun (wenyanwen ben, 1932), p. 55; "Da moujun", p. 256.

538 See ibid., pp. 255-256.

539 Ibid., p. 256.
} 
through Function".

How, then, can Reality be revealed through Function? Consistent with his previous understanding, between the late 1920s and mid-1930s Xiong still believed that the phenomenal world was generated because of our deluded attachment and constructed by our conceptualisation. That is, phenomena are mistakenly conceived as real, yet they are in fact only imaginative constructions and so empty of intrinsic nature. Based on this understanding, Xiong believed that we could see the truth (zhenshi 真實) - suchness or Reality - from the aspect of the myriad phenomena only when we are rid of the deluded attachment and emptied of all to which we are attached. ${ }^{540}$ This is like the case that when we realise that we mistake the rope for a snake, we will no longer see the snake as a snake but see it as the rope. In his 1933 writing, Xiong clearly stated:

所謂現象界者, 元依大用流行而施設如是假名。易言之, 萬有現象即 依流行中的虛僞相貌而假名之耳，元非有如世俗所執宇宙或實物事可 名爲現象界。“元非”一氣貫下讀之。蓋乃蕩除一切所執, 現象界即妄計所執。 而觀於流行，乃即用以識體，亦不於流行之外䍃體。541

The so-called phenomenal world has always been a nominal designation posited on the basis of great Function/flowing movement. In other words, the myriad phenomena are nominally designated on the basis of the illusory appearances [generated] in the process of the flowing movement; there has never been the "universe" or "real entities", to which the worldly [people] are attached, that can be named "the phenomenal world". We should read from "there has never" till the end of the sentence without a break. Therefore, [we should] eliminate all that we are attached to, The phenomenal world is precisely that to which mistaken discrimination is attached. and then observe [Reality] from the flowing

\footnotetext{
540 See, for example, Xiong, “Yu Zhang Jitong” 與張季同 (To Zhang Jitong), in Shili lunxue yu jilüe, pp. 231-232; “Jiangci”, pp. 252-253.

541 Xiong, “Po 'Po Xin weishi lun'”, p. 185.
} 
movement. This is to discern Reality through Function, which is also to say that Reality is not to be sought outside the flowing movement.

From Xiong's perspective, we are prevented from recognising Reality by the things in the phenomenal world. These things are not real, but are nominally posited based on our illusion of the flowing movement of Reality, that is, Function. Only when we eliminate our attachment to those things can we realise that there is nothing but ceaseless transformation, and that transformation is indeed constancy. This is what Xiong indicated as "revealing Reality through Function".

Recognising Reality through Function, in turn, enables us to realise that the so-called phenomenal world is devoid of self-nature. This is like the case that when we see the rope as a rope, we will realise that the snake is not real. By then, we will see that each of the myriad phenomena is indeed Reality:

吾宗千言萬語, 不外方便顯體。顯者, 顯明之也。本體難設言詮, 故須方便。見 到體時便無現界。即如凡情執有山河大地等相, 智者了知此等相都無 自性, 即是皆空。如實義者, 森羅萬象, 無非清淨本然, 即於萬象之上而 一一皆見其是清淨本然, 卻非謂萬象渾然成一合相, 始名清淨本然。此處切勿誤會。清淨本 然者, 本體之代語。實未曾有如世間情見所執山河大地等相可得故。

All the words and phrases of my thesis are nothing more than expedient means used to reveal Reality. To "reveal" is to "make evident". Reality is difficult to be explained in words, and so it is necessary to adopt expedient means. When one sees Reality, then [one will understand that] the phenomenal world does not exist. That is to say, the mental state of worldlings is attached to the existence of the characteristics of mountains, rivers, the earth, and so forth; the wise understand that none of these characteristics has self-nature, that is, all are empty. From the perspective of reality, the majestic, myriad phenomena are nothing other than the condition of intrinsic purity. That is to say, each and every one of the myriad phenomena is seen to be the condition of intrinsic purity. This is not, however, to say that it is when the 
myriad phenomena, in some undifferentiated fashion, form a composite that they start to be called "the condition of intrinsic purity". Be sure not to misunderstand this point. "The condition of intrinsic purity" is an alternative term for Reality. This is because in reality there have never existed the characteristics of mountains, rivers, the earth, etc., to which conventional false discriminations are attached. 542

When we have eliminated false attachment to those things in the phenomenal world as real existents, we will recognise Reality among them and then understand that the whole phenomenal realm is nothing but Reality. Elsewhere Xiong expressed this as follows: "When this is comprehended, each of the myriad images will be seen to be suchness, the ruler will be discerned among the flowing movement [of phenomena], and, naturally, stillness will not be ignored in activity" (會得時，於萬象皆見爲真如，於流行便識得主宰，於發用自不失靜止). ${ }^{543}$

Xiong's changing interpretation of the thesis of "revealing Reality through Function" during the period from the early 1920s to the mid-1930s plays an important role in our ability to comprehend his changing understanding of Reality and Function. In both the 1923 and the 1926 versions of Weishixue gailun, Xiong believed that Function was only provisionally established to negate mistaken attachments, thereby enabling Reality to be revealed. He did not, however, establish any connection between the phenomenal and the ontological in either of these works. In Weishi lun, he maintained that Function is nominally posited on the basis of Reality to negate the existence of real dharmas, and so it is not different from Reality. He further stated that Reality will be revealed naturally after the characteristics of conditioned phenomena have been emptied. Yet he did not elaborate on this view. Between the late 1920s and mid-1930s, he largely continued to develop this view. Through his explanation of "revealing Reality through

\footnotetext{
542 Xiong, Xin weishi lun (wenyanwen ben, 1932), p. 55; Makeham (trans. and annot.), New Treatise on the Uniqueness of Consciousness, p. 127, mod.

543 Xiong, Xin weishi lun (wenyanwen ben, 1932), p. 70.
} 
Function", as well as his proposition that "it is precisely Function that is Reality", he explicitly expressed the view that because Function is devoid of self-nature, it does not differ ontologically from Reality - for in order to differ it would have to have a self-nature, it would have to be real. Thus, when we have eliminated our attachment to the phenomenal world, we will be able to discern Reality amid ceaseless transformation.

\subsubsection{Undifferentiated Reality Permeates the Entire Phenomenal World}

As related already in the section 4.1 of this chapter, between the late 1920s and mid-1930s, Xiong held that Reality, which is non-individuated, permeates the phenomenal world, and the myriad things, respectively, become what they are dependent on it. In fact, this is another conspicuous point with respect to the relationship between Reality and Function that Xiong emphasised in his writings of this period. For example, he stated:

他是遍爲萬物實體, 無有一物得遺之以成其爲物者, 萬物皆以他而成
其爲萬物, 我固萬物之一, 即亦以他而成其爲我。所以, 我與一切人
和物, 雖若殊形, 而語及實性, 則是渾然一體。性者體之異名。544
Everywhere it [the shared origin of the myriad things in the universe]
is the Reality of everything. There is not a single thing that becomes
itself without it. All the myriad things become the myriad things
because of it. I am surely one of the myriad things, which means that I
become myself also because of it. Therefore, although all humans,
things, and I, seem to have different forms, we are one undifferentiated
body as far as our true nature is concerned. “Nature” is another name for
Reality.

This statement makes two points. First, the shared origin of the myriad things is the Reality of every individual thing. In other words, Reality simultaneously manifests

544 Xiong, Zun wen lu, pp. 570-571. 
as various things, and each individual thing, albeit with a form different from that of others, manifests the entire Reality. Second, although the myriad things have various forms, because none differs ontologically from the shared Reality, they actually are one body and thus harmonise with one another. The first point is the premise of the second, and the second is a corollary of the first.

Elsewhere Xiong highlighted and elaborated these two points in his writings between the late 1920s and mid-1930s. With respect to the first point, he stated:

大哉功能, 遍爲萬物實體! 極言其燦著, 一華一法界, 一葉一如來。 法界, 實體之異名。如來, 本佛號之一, 此則以目實體。……秋毫待之成體, 以莫不 各足。無有一物得遺功能以成體者, 雖秋毫且然, 况其他乎? 秋毫舉體即功能, 則秋毫非 不足, 他物可知已。蓋泯一切物相而攰指其體, 則同即一大功能而無不足也。

How great is productive power! Everywhere it is the Reality of everything! To speak in superlative terms of how glorious it is, it is "in a single flower there is the whole dharma-realm (dharmadhātu)";545 "in a single leaf there is the whole thus-come (tathāgata)". "Dharma-realm" is another name for Reality. Originally, "thus-come" is one of the [ten] epithets of the Buddha. Yet here it is used to refer to Reality. ... The newly-grown down depends on it [productive power] to become itself, and so there is not one thing that is not sufficient itself. As for the fact that there is not a single thing able to become itself without productive power, even the newly-grown down is like that, then how much more so in the case of everything else? Since the newlygrown down in its entirety is productive power, then the newly-grown down is not deficient. The case of other things can thus be understood. If the characteristics of all things are eliminated so that we can point [directly] at their Reality, then what they

\footnotetext{
545 As Makeham explains, here the "dharma-realm" (fajie 法界; dharmadhātu) refers to the universe as seen correctly rather than the conventional universe seen by worldly people. In seeing the universe this way, one's mind can penetrate all things. In this universe, all things interpenetrate; everything is present in everything else. Makeham (trans. and annot.), New Treatise on the Uniqueness of Consciousness, p. 114, note 51.
} 
share in common is a single great productive power, with none being deficient. ${ }^{546}$

This clearly shows Xiong's view that Reality permeates the entire phenomenal world. For Xiong, everything in the phenomenal world - no matter how tiny it is, even it is like the newly-grown down - represents the entire Reality. It is not the case that Reality is dissected into numerous constituent parts, with each part being the Reality of each individual thing, and that only the myriad things together, as a composite, are the manifestation of all of Reality. Xiong presented this view - that Reality permeates the entire phenomenal world - as one of the several meanings of “transformation" (bian 變) and referred to it as the meaning of "perfect" (yuanman 圓滿). 547

As for the second point mentioned above - that although the myriad things have various forms, because each of them is ontologically equivalent to the shared Reality, they actually are one body and thus harmonise with one another - Xiong further explained it as:

神變莫測，物萬不齊。不齊而齊，以各如其所如。因說萬法皆如，彼 此俱得, 封畛奚施? ……極物之繁, 同處各遍, 非如多馬, 一處不容, 乃若眾燈, 交光相網。

God-like transformation is unfathomable, [and so] the myriad things are unequal. Being unequal, yet they are also equal. This is because each is as it is. ${ }^{548}$ Hence it is said that the myriad dharmas are all suchness,

546 Xiong, Xin weishi lun (wenyanwen ben, 1932), pp. 49-50; Makeham (trans. and annot.), New Treatise on the Uniqueness of Consciousness, pp. 114-115, mod.

547 See Xiong, Xin weishi lun (wenyanwen ben, 1932), p. 49. I adopted Makeham's translation of the term yuanman 圓滿. See his New Treatise on the Uniqueness of Consciousness, p. 115.

548 This obviously is an allusion to Zhuangzi's 莊子 (ca. 369-286 BC) perspective in his "Qi wu lun" 齊物論 (Discourse on making all things equal). However, as Makeham points out, Xiong's reading of this essay might have been influenced more directly by Zhang Taiyan's Yogācāran reading of it in his Qi wu lun shi dingben 齊物論釋定本 (Definitive edition of explanation of “Discourse on Making All Things Equal"). Makeham (trans. and annot.), New Treatise on the Uniqueness of Consciousness, p. 116, note 58. See Zhang Taiyan's relevant words in his Qi wu lun shi dingben 齊物論釋定本 (Definitive edition of explanation of "Discourse on Making All Things Equal"), in Zhang Taiyan quanji 
and fully possess one another. How can boundaries be applied? ... [Although] things are extremely numerous, each completely occupies the same place. This is not like the case that many horses cannot be contained within the same place. Rather, it is like that the crisscrossing beams of light from many lamps envelop one another. ${ }^{549}$

To say things are unequal is to say they have different forms and characteristics. To say they are equal is to say none is, ontologically, different from suchness, namely, their common Reality. It is precisely because the myriad things are each the manifestation of the entire Reality that, although they appear different, they are the same ontologically, completely inclusive of one another. In this sense, the myriad things actually are one body, not separated by physical form. This is another meaning of "transformation", which Xiong referred to as "intermeshed everywhere" (jiaobian 交遍).

As we can see, Xiong's above two points are closely related to each other, just as he highlighted himself:

又 “交遍義” 不許併入 “圓滿義” 者, 一顯全體起用, 用成萬殊, 而 各稱體, 一一具足。一顯用成萬殊, 而重重無礙, 故一真法界, 非一 合相。二義相關, 不堪省略。如數一二, 言一已有二, 卻不可說只須 數一，不當及二。又不可說寧堪數二，不必及一。550

Further, as to why the meaning of "intermeshed everywhere" is not allowed to be incorporated into the meaning of "perfect", this is because [the latter] shows that Reality in its entirety is manifested as Function, that Function becomes the myriad different [things], and that each [of the myriad different things] tallies with Reality, with each being replete.

章太炎全集 (Complete works of Zhang Taiyan), Shanghai: Shanghai renmin chubanshe, 1986, vol. 6, p. 61.

549 Xiong, Xin weishi lun (wenyanwen ben, 1932), p. 50; Makeham (trans. and annot.), New Treatise on the Uniqueness of Consciousness, pp. 116-117, mod.

550 Xiong, “Da moujun”, pp. 271-272. 
[The former] shows that Function becomes the myriad different [things], yet the manifold [things interpenetrate] without obstruction, and, thus, the one true dharma-realm is not a composite. The two meanings are interrelated, and [the meaning of "intermeshed everywhere"] cannot be omitted. This is like counting the numbers one and two: when we say "one", it already contains the meaning of "two", yet it cannot be said that we need only to count "one" and should not touch upon "two". It can also not be said that we could rather count "two", yet there is no need to touch upon "one".

Moreover, as already mentioned, Xiong's point that each and every one of the myriad things manifests the entire Reality is a premise, based on which his point that all things are harmonised as one body, mutually inclusive without obstruction, is made tenable. With respect to this logic, Xiong also stated:

一人一物之心即是天地萬物之心，非形質所能隔別，故恆互相貫通。 ……華嚴 “一多相即，重重無盡”，理趣深玄。

The mind of a single person or a single thing is precisely the mind of heaven, earth, and the myriad things. This is not something that physical substance can separate. Thus, [all things] are permanently interconnected. ... The Huayan doctrines of "the mutual identity of one and many" and "all [things] are endlessly [interdependent]" carry a profound purport. 551

Here the "mind" refers to Reality. As this statement shows, by resorting to Huayan philosophy, Xiong expressed the view that because everything fully possesses the

\footnotetext{
551 Xiong, Xin weishi lun (wenyanwen ben), p. 81; Makeham (trans. and annot.), New Treatise on the Uniqueness of Consciousness, p. 180, mod. For an explanation of the Huayan doctrines of "the mutual identity of one and many" (yi duo xiangji 一多相即) and “all things are endlessly interdependent" (chongchong wujin 重重無盡), see Vincent Shen, “Being and Events: Huayan Buddhism's Concept of Event and Whitehead's Ontological Principle", in Chinese Metaphysics and Its Problems, eds. Chenyang Li and Franklin Perkins, p. 158.
} 
common Reality of the entire phenomenal universe, an individual thing and the many other things are mutually identical, and all things in the phenomenal universe are intersubsumed.

As for the two points - Reality in its entirety is manifested as each individual thing, and all things are intersubsumed - Xiong obviously drew on the Huayan doctrines of "the unobstructed interpenetration of the absolute and the phenomenal" and "the unobstructed interpenetration of each and every phenomenon", respectively. According to Peter N. Gregory, these two Huayan doctrines originated in Dushun's Fajie guanmen 法界觀門 (Discernments of the dharmadhātu). ${ }^{552}$ This text includes three main sections, with two of them being relevant here. One is the discernment of "the unobstructed interpenetration of the absolute and the phenomenal". This elucidates various ways in which phenomena and the absolute (Reality) interrelate. The other is the discernment of total pervasion and inclusion (zhoubian hanrong guan 周遍含容觀), that is, what was later called "the unobstructed interpenetration of each and every phenomenon". With this discernment, the absolute itself is ultimately transcended, and one enters the world of total interpenetration, in which each and every phenomenon is not only seen to contain each and every other phenomenon, but all phenomena are also seen to contain the totality of the unobstructed interpenetration of all phenomena. 553

Dushun's ideas were developed by later Huayan patriarchs, with Chengguan's interpretation of them being particularly similar to Xiong's perspective. According to Gregory, Chengguan not only developed Dushun's two discernments in his theory of the fourfold dharmadhātu (si fajie 四法界),554 but also further illuminated the

\footnotetext{
552 According to Gregory, Dushun is only a putative author of Fajie guanmen, and his authorship of this text has been much disputed. See Gregory, Tsung-mi and the Sinification of Buddhism, p. 5, note 3.

553 Ibid., pp. 6, 7.

554 In his theory of the fourfold dharmadhātu, Chengguan presented four different perspectives with which the dharmadhātu can be understood: the realm of individual phenomena (shi fajie 事法界),
} 
relation between the doctrines of "the unobstructed interpenetration of the absolute and the phenomenal" and "the unobstructed interpenetration of each and every phenomenon":

所以事事不同而得無礙者, 以理融事故。……明依理成事, 故一與多互 爲緣起。……事理無礙, 方得事事無礙。若事不即理, 事非理成, 則 互相礙。今由即理, 故得無礙。……事得理融, 則千差涉入而無礙。555 The reason that each phenomenon is different from every other phenomenon and yet is unobstructed by all other phenomena is that the absolute permeates phenomena. ... Because phenomena are formed on the basis of the absolute, the one and the many arise in dependence upon one another. ... It is only as a result of the non-obstruction of the phenomenal and the absolute that the non-obstruction of phenomena and phenomena is made possible. Were phenomena not identical with the absolute, they would not be formed from the absolute, and phenomena would then obstruct one another. However, because they are identical with the absolute, they are unobstructed. ... Since phenomena are formed from the absolute, they are included in one another without obstruction. ${ }^{556}$

Xiong's view that non-individuated Reality permeates the myriad things in the phenomenal world, that the myriad things become what they are dependent on it, and that each individual thing is the manifestation of the entire Reality, resembles

in which dharmadhātu is viewed in terms of differentiated phenomena (shi 事); the realm of the absolute (li fajie 理法界), in which dharmadhātu is viewed in terms of the true nature (xing 性) that is common to all dharmas; the unobstructed interpenetration of the absolute and the phenomenal, and; the unobstructed interpenetration of each and every phenomenon. See ibid., pp. 67-68.

555 Chengguan 澄觀, Dafangguang fo Huayan jing suishu yanyi chao 大方廣佛華嚴經隨疏演義鈔 (Sub-commentary and explanation of the meaning of the Huayan Sutra), vol. 1, in the CBETA edition of the Taishō Tripițaka, T36n1736_001,0009a27.

556 Quoted and translated by Peter N. Gregory in his Tsung-mi and the Sinification of Buddhism, p. 163. 
the doctrine of the unobstructed interpenetration of the absolute and the phenomenal. His view that, although the myriad things have different forms and characteristics, they actually are one body and are mutually inclusive without obstruction, resembles the doctrine of the unobstructed interpenetration of each and every phenomenon. Specifically, Xiong's logic that every thing's possession of the entire Reality entails that all things are interconnected and mutually inclusive without obstruction seems to be consistent with Chengguan's emphasis that the unobstructed interpenetration of the absolute and the phenomenal is the cause for the unobstructed interpenetration of each and every phenomenon.

\section{Concluding Remarks}

During the period between 1927 and 1937, Xiong further developed his philosophy of Reality and Function by drawing largely on the Dasheng qi xin lun, the NeoConfucian School of Mind, Huayan philosophy, and Ma Yifu's thought. First, he identified Reality with our mind. He presented this mind as something that we possess inherently, and referred to it as "the inherent mind" - a term he appropriated from the School of Mind - or "the real mind". He differentiated it from the "false consciousness" that grasps cognitive objects and that illusorily arises depending on it. In differentiating between the real mind and the false consciousness, he was probably inspired by the idea of "the two aspects of the one mind" presented in the Dasheng qi xin lun. Moreover, Xiong further described the inherent mind/real mind as something that is able to realise itself by appropriating the concept of "innate moral knowledge" as propounded by Wang Yangming, and by drawing on the Yogācāra idea of "wisdom". With respect to Reality's realisation of itself, since that which realises and that which is realised are the same thing, there is actually no demarcation between the subject and the object.

In addition to identifying Reality with our mind, Xiong also developed his understanding of Reality with respect to whether it is constant/quiescent or transforming/moving. In both the 1923 and the 1926 versions of Weishixue gailun, 
Xiong followed Yogācāra philosophy to consider suchness, or Reality (to be more exact, the ontological Reality in those two works), to be an unconditioned dharma, which is constant and not subject to arising, changing, and ceasing. In Weishi lun, he replaced the Yogācāra concept of suchness with his reconstructed concept of productive power, or constant transformation, and presented Reality as something that arises and ceases, or transforms. Between the late 1920s and mid-1930s, Xiong's perspective changed again. He endowed Reality with a characteristic of both transformation and constancy by resorting to the concepts of "transformation" and "constancy" presented in the "Yi qian zao du", and also under the influence of Ma Yifu. For Xiong, although Reality always transforms, there is an unchanging nature inherent in its transformation. In this sense, transformation is indeed constancy.

In fact, Xiong stated the transformation of Reality in terms of its illusory manifestation, or Function. He stated the constancy of Reality in terms of its intrinsic nature, that is, Reality itself. Consistent with his view that transformation is indeed constancy, Xiong presented the relationship between Reality and Function as "it is precisely Function that is Reality". In his view, Function, or the phenomenal activities of arising, ceasing, changing, and moving, is devoid of self-nature, and what underpins these illusory appearances is the constant Reality. In this sense, Reality and Function do not differ ontologically. Xiong's proposition that "it is precisely Function that is Reality" provided him with a basis on which he was able to make his view of "revealing Reality through Function" tenable. It is precisely because Function is the illusory manifestation of Reality, and Reality cannot exist independent of Function, that we are able to recognise Reality through Function after we have removed our deluded attachment to phenomenal appearances.

For Xiong, Reality cannot be conceived or linguistically expressed, and, thus, just as Makeham notes, such concepts as productive power and constant transformation, like all verbal characterisations of Reality, are all employed 
nominally, as a skilful/expedient means. 557 That is to say, based on his view that Function does not differ from Reality and his goal to reveal Reality through Function, Xiong nominally described Reality in terms of its Function. He therefore used such concepts as "productive power" and "constant transformation" concepts he presented with reference to the uninterrupted arising and ceasing of phenomena, i.e., the flowing movement, or Function, of Reality - to refer to Reality.

In addition to his proposition that "it is precisely Function that is Reality", Xiong also developed another prominent idea in his writings between the late 1920s and mid-1930s with regard to the relationship between Reality and Function. That is, non-individuated Reality manifests itself simultaneously as the various things in the phenomenal world, and each individual thing represents the entire Reality. As a result, all things in the phenomenal world are mutually inclusive without obstruction. The first half of this idea, that regarding the relation between Reality and the things in the phenomenal world, clearly resembles the Huayan doctrine of "the unobstructed interpenetration of the absolute and the phenomenal", while in the latter half concerning the relation between the things in the phenomenal world, Xiong drew obviously on the Huayan doctrine of "the unobstructed interpenetration of each and every phenomenon". Particularly, his logic that non-individuated Reality permeates the various things in the phenomenal world equally leads to the conclusion that all things in the phenomenal world are mutually inclusive without obstruction seems to be consistent with the fourth Huayan patriarch Chengguan's emphasis on the unobstructed interpenetration of the absolute and the phenomenal as the cause for the unobstructed interpenetration of each and every phenomenon.

Above all, in the period between 1927 and 1937, Xiong interpreted his view that Reality and Function are non-dual in a new way. That is to say, in his Weishi lun, by presenting Function (the phenomenal world) as the two impetuses

\footnotetext{
557 See Makeham, "Xiong Shili's Understanding of the Relationship between the Ontological and the
} Phenomenal", p. 218. 
(compression and extension) of Reality (constant transformation, or productive power), Xiong demonstrated the non-duality of Reality and Function. Between 1927 and 1937, he demonstrated this view further by presenting Reality and Function as the two aspects - the inherent nature and the illusory manifestation of our mind, which apparently accords with the idea of "the two aspects of the one mind" in the Dasheng qi xin lun.

Moreover, by presenting his understanding of Reality and Function during this period, Xiong responded to the movement of the retrieval of "genuine" Buddhism and its related debates, which, as introduced in Chapter One, occurred in the early decades of the twentieth century and indicate an antagonism between the Dharmapāla-Xuanzang tradition of Yogācāra and the Dasheng qi xin lun. His presentation of Reality as both transforming and constant shows his perspective that Reality is active, which can be considered a response to the issue of whether Reality is quiescent or active - an important issue in the "genuine Buddhism" movement and the debates. Furthermore, his identification of Reality with our inherent mind/innate moral knowledge/wisdom shows his perspective that our mind is inherently awakened and, thus, can be considered a response to the question of whether the mind of sentient beings is inherently enlightened, an issue also associated with the movement and the debates. Most of all, as shown in this chapter, both of Xiong's perspectives above are consistent with the Dasheng qi xin lun but contradict views in the Dharmapāla-Xuanzang tradition of Yogācāra. This, as well as Xiong's obvious adoption of the ideas in the Dasheng qi xin lun and Huayan philosophy during the period between 1927 and 1937, shows his support for the Dasheng qi xin lun and its related Sinitic Buddhist ideas, as well as his further deviation from Yogācāra philosophy. 


\section{Conclusion}

This thesis has closely examined Xiong Shili's understanding of Reality and Function between 1920 and 1937. In this Conclusion, I will first review how Xiong initially presented his conception of Reality and Function and then revised and developed it. Next, based on my study, I will briefly discuss two main questions, and expand each into several issues. The first is: why is Xiong's philosophy of Reality and Function unique? To answer this question, I will describe the originality of Xiong's interpretation of, and approach to, the concepts of Reality and Function, and clarify the extent to which he developed ideas that were well formed already, as well as the extent to which he proposed a radical departure from earlier thinkers. I will discuss specifically the extent to which Xiong was consciously and deliberately syncretic in developing his metaphysics, as this approach was very important for elucidating his views of Reality and Function. The reason Xiong's philosophy of Reality and Function is unique will also illustrate the contribution he made to the development of the ti-yong conceptual polarity in the broader context of the history of Chinese philosophy. The second question is: why did Xiong continue to modify and develop his conception of Reality and Function during the period between 1920 and 1937? To answer this question, I will highlight the changes and development in Xiong's thought and discuss the meaning of, and reasons for, them. The answer to this question also requires a discussion of Xiong's changing attitude towards human life, as well as the reason for it.

\section{A Review of Xiong's Changing Understanding of Reality and Function between}

\section{0 and 1937}

In this thesis, I have divided Xiong's understanding of Reality and Function between 1920 and 1937 into three chronological stages: 1920 to 1923,1923 to 1927 , and 1927 to 1937, during which Xiong gradually established his mature ti-yong 
philosophy.

From 1920 to 1923, Xiong did not elaborate his views of Reality and Function systematically, but he did reflect more on these concepts in his 1923 Weishixue gailun. This work concentrates on explicating Yogācāra philosophy, and Xiong's opinions of Reality and Function in it are reflected in his accounts of Yogācāra theories of consciousness, suchness, productive power, and manifest activity. Xiong also drew heavily on the Madhyamaka differentiation of ultimate and conventional truths, as well as on Ouyang Jingwu's understanding of Reality and Function, to present a two-level ti-yong system in the 1923 work. On the level of ultimate truth, suchness is Reality, and consciousness, which represents the entire phenomenal world, is Function. Suchness is the only thing that truly exists. It is constant and not subject to conditions. In contrast, consciousness does not truly exist: it is only nominally posited so as to refute the view that phenomena are real and thereby enable Reality to be revealed or disclosed. In addition to this understanding, Xiong did not establish any connection between Reality and Function. As such, he actually presented a Reality without Function at this level. At the level of conventional truth, productive power is Reality, and manifest activity is Function. Manifest activity refers to consciousness or the dharmas in which consciousness is manifested. Productive power was established as the cause of manifest activity. Both productive power and manifest activity are conditioned dharmas that arise and cease and are included within the realm of consciousness. Although they stand in a relation of cause and effect, the two are not separate or distinct. Instead, for Xiong, they are two aspects of the same thing: productive power is the intrinsic nature, the latent, and the potential; manifest activity is the external appearance, the manifest, and the actual. At this level, then, Reality and Function are non-dual.

In the stage from 1923 to 1927, Xiong revised his views of Reality and Function. This revision can be divided into two steps, reflected in his 1926 Weishixue gailun and Weishi lun, respectively. The 1926 Weishixue gailun is a revised version of Xiong's account of Yogācāra learning. In it, Xiong criticised and 
reconstructed the Yogācāra concepts of productive power and consciousness, or manifest activity, as well as its theory of transformation. He also drew on the concept of "ceaseless generation" and the idea that the interaction between two opposing elements results in change (in particular Zhang Zai's interpretation of it) as found in Zhouyi. Through these approaches, Xiong revised his understanding of conventional Reality and its Function as presented in the 1923 work. For Xiong, this Reality - which he referred to as "constant transformation", and which is his reconstructed concept of productive power - is an entire process of constantly abandoning the past and creating the new, or a continuum of momentary transformations (ceasing and arising), and manifest dharmas are those nominally posited on the basis of its two impetuses, compression and extension. In this way, he presented conventional Reality and Function as non-dual.

In the 1926 work, however, Xiong did not revise the level of ultimate truth in his two-level ti-yong system. It was in Weishi lun that he changed his understanding of ontological Reality and its relation with Function, and abandoned the framework of a two-level ti-yong system. Xiong now changed his former view that constant transformation, or productive power, as the Reality of the phenomenal world, is merely a provisional establishment. Instead, he took it to be ontological Reality directly. As such, he upheld only a single pair of Reality and Function, and finally realised the non-duality of the ontological and the phenomenal.

Between 1927 and 1937, Xiong further developed his conception of Reality and Function. This development is reflected in his many sayings and writings of this period, but most importantly in the 1932 Xin weishi lun. During this period, Xiong drew on a range of sources: the idea of "the two aspects of the one mind" presented in the Dasheng qi xin lun; the concept of "the inherent mind" in the Neo-Confucian School of Mind, and in particular Wang Yangming's development of it; the doctrines of "the unobstructed interpenetration of the absolute and the phenomenal" and "the unobstructed interpenetration of each and every phenomenon" in Huayan philosophy; and Ma Yifu's thought. By integrating these into his own philosophy, 
Xiong re-interpreted his earlier view that Reality and Function are non-dual. He now identified Reality with our mind and characterised it as both transforming and constant: transformation is described in terms of its illusory manifestation, that is, Function or the phenomenal world; constancy is described in terms of its inherently unchanging nature, that is, Reality itself. Based on this understanding, Xiong held that Reality and Function do not differ ontologically and that the former permeates the latter.

\section{Why is Xiong's Philosophy of Reality and Function Unique?}

Although many Chinese thinkers before Xiong had already explored the concepts of Reality and Function, Xiong's interpretation of, and approach to, this polarity are uniquely and creatively syncretic. As we have seen, during the period between 1920 and 1937, in addition to Yogācāra philosophy, which serves as the ground on which he established his ti-yong philosophy, Xiong also drew on a wide range of other sources, including other traditions of Buddhism (Madhyamaka, the Dasheng qi xin Iun, Huayan, etc.) and Confucianism (Zhouyi, the Neo-Confucian School of Mind, etc.), and even from his contemporaries (Ouyang Jingwu, Ma Yifu). He availed himself not only of other thinkers' ideas, but also used their approaches to those ideas, such as the Buddhist metaphor of the sea and its waves. As for these sources, Xiong adopted a method of "using the six classics to explain my thought" (liujing zhu wo 六經注我). That is to say, he accumulated knowledge from these sources and then reinvented them in light of his own understanding to form his own philosophy. He did not necessarily follow the conventional understanding of these sources, but he adapted and creatively re-interpreted them to explain and prove his own views. ${ }^{558}$ In what follows, I will summarise the way Xiong used different

\footnotetext{
558 On this point, Jiyuan Yu also states: "Xiong's philosophical goal was not 'to comment on the six classics', but for "the six classics to comment for me"; that is to say, he did not aim to be a faithful commentator, but saw himself as an original thinker who based his work on the ancient classics." Jiyuan Yu, "Xiong Shili's Metaphysics of Virtue", in Contemporary Chinese Philosophy, eds. Chung-ying Cheng and Nicholas Bunnin, Malden, Mass.: Blackwell Publishers, 2002, p. 128.
} 
sources to illuminate his own views of Reality and Function, and, at the same time, clarify the extent to which he was developing, or departing from, former ideas.

First, Xiong's understanding of Reality and Function has its roots in Yogācāra Buddhism. Xiong's dissatisfaction with Yogācāra was an important factor that led him to establish his own ti-yong philosophy; as such, his account of Reality and Function was based to a large extent on his critique and reconstruction of certain Yogācāra theories. Originally, in the early 1920s, he followed the Yogācāra understanding of the concepts of suchness and consciousness to develop his understanding of ontological Reality and Function. However, the relationship between suchness and consciousness in Yogācāra contradicts the conventional understanding of ti-yong in traditional Chinese philosophy. In traditional Chinese philosophy, ti and yong as a conceptual polarity are inter-related: $t i$ is the $t i$ of $y o n g$, and yong is the yong of $t i$. The two are two aspects of the same thing. In contrast, in Yogācāra philosophy, although suchness is the true nature of consciousness or phenomena, consciousness/the phenomenal world is neither the manifestation of, nor is it generated by, suchness. As an unconditioned dharma, suchness has nothing to do with phenomenal activities.

The incompatibility of the suchness-consciousness relationship in Yogācāra philosophy with the ti-yong relationship in traditional Chinese philosophy probably led Xiong to become critical of the Yogācāra view that suchness is Reality and consciousness is Function. According to Xiong, in Yogācāra philosophy, the distinction between unconditioned suchness as Reality and conditioned consciousness as Function promotes a division of Reality and Function into two parts. For him, this is like saying that behind the universe that changes, moves, arises, and ceases, there is a separate Reality, which does not change, move, arise, or cease. ${ }^{559}$ In the mid-1920s, Xiong turned to the other understanding of ti-yong he had proposed in the early 1920s - productive power as conventional Reality and

559 Xiong, “Jiangci” 講詞 (Speech), in Shili lunxue yu jilüe, p. 274. 
manifest activity/consciousness/phenomena as its Function. He reconstructed this pair of Reality and Function and came to regard it as existing at the level of ultimate truth. In this way, he used his reconstructed concept of productive power to replace suchness as ontological Reality and presented ontological Reality and its Function as non-dual. As such, he actually deviated from the Yogācāra understanding of the relationship between the ontological and the phenomenal.

Second, while criticising and reconstructing Yogācāra philosophy, Xiong also drew extensively upon accounts of Reality and Function in traditional Chinese philosophy to develop his view that Reality and Function are non-dual. In the 1926 Weishixue gailun, Xiong developed his views of productive power as Reality and manifest activity as Function by integrating with them certain ideas derived from Zhouyi. Through this development, when Xiong used his reconstructed concept of productive power to replace the Yogācāra concept of suchness as ontological Reality in his Weishi lun, ontological Reality and its Function then became a process of ceaseless transformation and its impetuses. This interpretation of "the non-duality of Reality and Function", with its syncretisation of Yogācāra and Zhouyi, was unprecedented. It laid the foundations for the subsequent development of Xiong's thought.

Although Xiong drew on various sources between 1920 and 1937, he did not accept their ideas entirely, but appropriated and sublated them selectively. For example, he adopted Sengzhao's differentiation of the two truths to elucidate his own view that things are actually tranquil although they seem to be moving, but he did not adopt Sengzhao's emphasis on the ultimate extinction of things. Rather, he emphasised the continuous arising of dharmas. Moreover, Xiong adopted Madhyamaka Buddhism's apophatic method so as to demonstrate his view that phenomena are devoid of self-nature. Yet he departed from Madhyamaka to claim that Reality is the ontological ground on which the phenomenal world illusorily appears. Further, although Zhang Zai's philosophy is an important source of Xiong's metaphysics, Xiong did not accept Zhang's thought entirely. He consulted only 
Zhang's interpretation of the idea that the interaction between yin and yang forms transformation as presented in Zhouyi, but he did not adopt Zhang's view that Reality and Function are only two forms of the state of vital stuff, which is the source of all phenomena. Rather, he followed Buddhist philosophy and maintained that all phenomena are illusory, 560 which is a radical departure from Zhang's thought.

This syncretism of different schools of thought in order to establish an original ti-yong based metaphysics is a hallmark of Xiong's creativity. This syncretism was conscious and deliberate and is in evidence as early as in the Weishi Iun. In the "Preface" to that work, Xiong relates that initially he admired the breadth and precision of Dharmapāla's learning, but later found it faulty and inaccurate, and searched for the truth (zhenji 真際; bhütakoți) elsewhere. Unable to achieve that goal through book learning, he eventually abandoned all books, observed things without grasping their appearances, and then comprehended the profound meaning of wisdom (bore 般若; prajñā) outside words. He believed that what he had apprehended was indeed consistent with the thought of the early masters, such as Śākyamuni (Shijia 釋迦, probably 6th-5th or 5th-4th century BC) and Nāgārjuna (Longshu 龍樹, ca. 150-250).561 Thus, the sources he drew upon in Weishi lun are restricted to those he found to be consistent with his own thought. This is the initial indication that Xiong was conscious of his approach of syncretism.

In Zun wen lu, Xiong further noted that he had absorbed various sources for the draft of his 1932 Xin weishi lun:

弟之《新唯識論》, 雖從印土嬗變出來, 而思想根柢, 實乃源於《大 易》，旁及柱下漆園，下迄宋明鉅子，亦皆有所容攝。562

Although my Xin weishi lun is derived from India [Indian philosophy], the root of its thinking indeed originates in Dayi 大易 (Great change)

\footnotetext{
560 For a discussion of this point, see also Chan, A Source Book in Chinese Philosophy, p. 764.

561 Xiong, Weishi lun, pp. 501-502.

562 Xiong, “Da youren” 答友人 (Reply to a friend), in Zun wen lu, p. 665.
} 
[Zhouyi]. From Zhuxia 柱下 [i.e. Laozi] and Qiyuan 漆園 [i.e. Zhuangzi] through to the influential philosophers in the Song and Ming dynasties, all are incorporated within it to some extent.

Similarly, Xiong once said in the mid-1930s that to understand his philosophy fully, one must research both the Madhyamaka and Yogācāra schools, as well as traditional Chinese philosophy from the Confucian and Daoist schools of the Zhou period (1046-256 BC) through to the various philosophers of the Wei, Jin, Song, and Ming dynasties, after which one would know that his understanding of truth (zhenli 真理) is consistent with that of those previous philosophers, even if the paths they followed differ. ${ }^{563}$ The above shows that by the early 1930s Xiong had already been very explicit about his syncretic approach.

Why, then, did Xiong choose to use this approach when he developed his metaphysics? First, this is related to his motivation to pursue learning. When Xiong looked back on the 1920s and 1930s in a later period, he stated that his motivation to pursue learning was not to broaden his scholarship but rather to seek truth (zhenli 真理) and secure a meaningful life (anxin liming 安心立命).564 Because of this motivation, he never rigidly adhered to a particular school of thought but employed ideas from different philosophical schools to elucidate his own views. Second, just as mentioned above, Xiong believed that those sources he drew on actually share the same understanding of truth with him. ${ }^{565}$ He therefore integrated them with his own metaphysics. Third, Xiong was trained in traditional Chinese philosophy before 1920. As Chen-kuo Lin points out, Xiong's mode of thinking and world-view was embedded in the kind of language and discourse most familiar and available to him. Although these language and discourse were suppressed when Xiong turned to Yogācāra Buddhism, they could not be

\footnotetext{
563 Xiong, “Yu Laisheng” 與賴生 (To Mr. Lai), in Shili lunxue yu jilüe, p. 249.

564 Xiong, Xin weishi lun (yutiwen ben, 1944), pp. 135-136.

565 On this point, see also Xiong, “Jiangci”, p. 254.
} 
completely erased.566 Thus, when Xiong was reconstructing Yogācāra philosophy and developing his own metaphysics, it was natural for him to resort to those sources in traditional Chinese philosophy, with which he had already been very familiar.

As Makeham relates, "over the past three decades, there has been a widespread tendency to portray Xiong narrowly as a Confucian philosopher who also happened to criticise Buddhist philosophy".567 Nevertheless, from the above, we can see that because Xiong syncretised different schools of thought and then built his own metaphysical system, he retained an individual identity in his thinking and cannot be classified under a single "school" of thought, at least before 1937. In the period between 1920 and 1937, Buddhism and Confucianism served only as foundations on which he established his own constructive philosophy. Just as Xiong emphasised that his 1932 Xin weishi lun synthesised Buddhism and Confucianism and became an independent system, and it was the crystallisation (jiejing 結晶) of Oriental philosophical thought (dongfang zhexue sixiang 東方哲學思想).568

\section{Why did Xiong Continue to Modify and Develop His Conception of Reality and Function?}

Generally speaking, the changes in, and development of, Xiong's understanding of Reality (that is, ontological Reality, rather than the conventional Reality he presented in his 1923 and 1926 works) and Function during the period between 1920 and 1937 can be summarised as follows. First, Xiong moved from considering Reality and Function as two distinct realms to presenting them as non-dual, with

\footnotetext{
566 Chen-kuo Lin, "Hsiung Shih-li's Hermeneutics of Self: Making a Confucian Identity in Buddhist Words", NCCU Philosophical Journal, vol. 8, June 2002, p. 86.

567 Makeham (trans. and annot.), New Treatise on the Uniqueness of Consciousness, p. xv. See also his discussions of this issue on pp. xv-xxii.

568 Xiong, “Zhi Lü Cheng bing fu yu Liang Shuming lun Yihuang dashi” 致呂澂並附與梁漱溟論宜黃 大師 (To Lü Cheng, enclosed with my “Discussion with Liang Shuming about the Venerable Master from Yihuang"), in Xiong Shili quanji, vol. 8, p. 422-423.
} 
the latter being the illusory manifestation of the former. Second, he developed his understanding of the characteristic of Reality from being constant/quiescent to being transforming/active, and then to being simultaneously constant/quiescent and transforming/active. As discussed already, this reflects a move from believing that Reality has nothing to do with phenomenal activities to considering phenomenal activities as the illusory manifestation of Reality. Third, Xiong shifted from believing that consciousness is provisionally established for the sake of revealing suchness to identifying our mind with Reality. As shown in this thesis, these changes and developments also reflect Xiong's gradual departure from Yogācāra philosophy and approval of such Sinitic Buddhist traditions as the Dasheng qi xin lun and Huayan, as well as his increasing adoption of ideas from Confucian traditions, such as the Neo-Confucian School of Mind.

The above, then, raises the questions: Why did Xiong change from taking Reality and the phenomenal world to be distinct realms, to considering the latter as the illusory manifestation of the former? Why did he identify Reality with our mind? And why did he depart from Yogācāra philosophy and draw closer to such Sinitic Buddhist traditions as Huayan?

As discussed in the Introduction of this thesis, Xiong was quite passionate about social and political affairs in his early period before 1920, and the initial reason for his transition from revolution to scholarship and learning is his intention to take a new approach to save the nation and people. Xiong's view that the phenomenal world discloses Reality, as well as his identification of our mind with Reality, can be said to be a reflection of this intention to some extent. Just as Peter N. Gregory points out:

If Buddhism taught that the defiled phenomenal world was ultimately nothing but a manifestation of an intrinsically pure ground, then it would be possible for Chinese Buddhists to fashion an ontology that would affirm the phenomenal word of human endeavour that had been the primary focus of the this-worldly and humanistic concerns of 
traditional Chinese thought. Such was the tack taken by Huayan. On the other hand, the Faxiang tradition of Yogācāra, introduced to China by Xuanzang, held that there was an unbridgeable gap between the defiled world of delusion and the pure mind of enlightenment. ... It was primarily around this issue that Huayan rejected Faxiang as representing only a quasi-Mahāyāna teaching. 569

This is what Gregory describes as the "accommodation of Buddhism with Chinese values".570 This also goes some way to answering the questions above. Further, to find Reality by returning to the mind bestows power on humans because it shows that they are able to save themselves through their own efforts, and accordingly, there always is hope for human society. Also, as Douglas L. Berger states, if we possess a kind of consciousness, which can also be called the "luminosity of mind", that thoroughly, limitlessly, and faultlessly manifests the world, then we can fully actualise that same awareness in knowing and acting, and it would be possible for persons to become perfect. This, according to Berger, is an "incorrigible optimism about human beings", which is a legacy of classical Asian thought, including the thought of such Chinese schools as Huayan and Confucianism. ${ }^{571}$

Moreover, the changes and developments in Xiong's understanding of Reality and Function between 1920 and 1937 are also consistent with his changing attitude towards human life in this period. Xiong once stated in the mid-1930s that his attitude to human life in the 1932 Xin weishi lun changed from Buddhism to Confucianism. According to him, Buddhists insist on an escapist view of transcending life and death with the goal of extinction (jimie 寂滅), whereas Confucians advocate vigour (gangjian 剛健) and creativity (chuangxin 創新) without fearing mortality (sisheng 死生) and delighting in extinction. Xiong

\footnotetext{
569 Gregory, Tsung-mi and the Sinification of Buddhism, p. 110.

570 Ibid.

571 Douglas L. Berger, Encounters of Mind: Luminosity and Personhood in Indian and Chinese Thought, Albany: State University of New York Press, 2015, p. 10.
} 
claimed that because of what Confucianism advocates, it belongs to Chinese thought. 572 Elsewhere in his writings of the mid-1930s, Xiong also emphasised that Buddhist thought transcends the mundane world (chu shi 出世) and strives for extinction ( $q u$ ji 趣寂), whereas his 1932 Xin weishi lun focuses on human life without discussing the religious view of transcendence. 573 Obviously, the changes and developments in Xiong's understanding of Reality and Function discussed above, which indicate his increasing concern about the society and human affairs, are in line with this change of his attitude to human life.

From the above, we can also see that although Xiong was a syncretist, because the Confucian attitude towards human life and its salvation of the world conformed to his own thought he started to draw close to Confucianism in the period between 1920 and 1937. Further, as Sor-hoon Tan relates, New Confucianism arose from the intellectual crisis around the May Fourth period in China. Confronting the challenge of Western modernity and the attacks on traditional Chinese culture, New Confucians were committed to promoting Chinese culture with Confucianism as its core, and they believed in its perennial relevance and value. Xiong was among this group. ${ }^{574}$ On this point, Jiyuan Yu further relates that since the May Fourth Movement in 1919, Confucianism had been blamed for China's weakness and decline in the face of Western aggression. Others, however, argued that the underlying problem was the loss of the authentic Confucian dao 道 (the way). Accordingly, the way forward was not to abandon Confucianism, but to rediscover and revive its real spirit. The main representative of this voice in contemporary Chinese philosophy was Xiong Shili. ${ }^{575}$ Indeed, Xiong once stated explicitly that the reason he wrote the 1932 Xin weishi lun was because he wanted to develop Chinese

\footnotetext{
572 Xiong, “Jiangci”, p. 254.

573 Xiong, “Jiangci”, pp. 273-274.

574 Tan, “Contemporary Neo-Confucian Philosophy”, pp. 539-540.

575 Jiyuan Yu, “Xiong Shili's Metaphysics of Virtue”, p. 127. Jana S. Rošker also points out that Xiong belonged to the relatively small number of philosophers who opposed the anti-Confucian tendencies that prevailed during the first decades of the twentieth century. Rošker, "Modern Confucian Synthesis of Qualitative and Quantitative Knowledge”, p. 376.
} 
philosophy. 576 Therefore, it is possible that Xiong intended to develop Chinese culture by supporting Confucianism, which was widely believed to be an important part of traditional Chinese culture.

Above all, Xiong did not publically align himself with Confucianism in the period between 1920 and 1937. However, his support for the Confucian attitude to human life laid a foundation for his later turn to Confucianism. After the outbreak of the Anti-Japanese War in 1937, because of the intense national crisis brought on by the war, Xiong's emphasis changed from reconstructing Indian Yogācāra philosophy to identifying the value of traditional Chinese philosophy, and in particular Confucianism. As a result, his ti-yong philosophy continued to develop in complexity beyond the period between 1920 and 1937, as he responded to new intellectual influences and the demands of a changing intellectual and political environment. This study of Xiong's metaphysics between 1920 and 1937 has laid the foundations for tracing the later periods of his philosophical thought.

576 Xiong, “Da Zhang Dongsun” 答張東蓀 (Reply to Zhang Dongsun), in Shili lunxue yu jilüe, p. 310. 


\section{Works Cited}

Ames, Roger T. "Putting the Te back into Taoism". In Nature in Asian Traditions of Thought: Essays in Environmental Philosophy, eds. J. Baird Callicott and Roger T. Ames. Albany: State University of New York Press, 1989.

Aviv, Eyal. "Ouyang Jingwu: From Yogācāra Scholasticism to Soteriology". In Transforming Consciousness: Yogācāra Thought in Modern China (q.v.), ed. John Makeham.

Berger, Douglas L. Encounters of Mind: Luminosity and Personhood in Indian and Chinese Thought. Albany: State University of New York Press, 2015.

Berthrong, John. “Zhu Xi's Cosmology”. In Dao Companion to Neo-Confucian Philosophy (q.v.), ed. John Makeham.

Blumenthal, James. “Two Topics Concerning Consciousness in Śāntarakşita's YogācāraMadhyamaka Syncretism". In Madhyamaka and Yogācāra: Allies or Rivals? (q.v.), eds. Jay L. Garfield and Jan Westerhoff.

Bol, Peter K. Neo-Confucianism in History. Cambridge: Harvard University Press, 2008.

Cai Renhou 蔡仁厚. Xiong Shili xiansheng xuexing nianbiao 熊十力先生學行年表 (A chronology of Mr. Xiong Shili's learning and deeds). Taibei: Mingwen shuju, 1991.

Cao Zhicheng 曹志成. “Hufa Xuanzang yixi yu Anhui yixi dui shi zhuanbian zhi jieshi de bijiao yanjiu” 護法-玄牀一系與安慧一系對識轉變之解釋的比較研究 (A comparative study between the Dharmapāla-Xuanzang tradition and the Sthiramati tradition on their explanations of "the transformation of consciousness"). Yuanguang foxue xuebao 圓光佛學學報, issue 2, October 1997, pp. 81-90.

Chan, Wing-tsit. A Source Book in Chinese Philosophy. Princeton, NJ: Princeton University Press, 1963.

——. Religious Trends in Modern China. New York: Columbia University Press, 1953.

Chang Zhengrong 常崢峥. “Ouyang Jingwu de sanchong sizhong ti yong guan” 歐陽竟無 的三重四種體用觀 (Ouyang Jingwu's three-tier and four-kind ti-yong system). Zongjiaoxue yanjiu 宗教學研究, no. 4, 2012, pp. 134-138.

Chen Lai 陳來. Renxue bentilun 仁學本體論 (Benevolence-based ontology). Beijing: Shenghuo, dushu, xinzhi sanlian shudian, 2014.

- - .XXiong Shili yu xiandai xin rujia de 'zhexue' guannian” 熊十力與現代新儒家的 “哲 學” 觀念 (Xiong Shili and the concept of “philosophy” in modern New Confucianism). In idem, Xiandai Zhongguo zhexue de zhuixun: xin lixue yu xin xinxue 現代中國哲學的 追尋: 新理學與新心學 (The pursuit of modern Chinese philosophy: New Principlecentred Learning and New Mind-centred Learning). Beijing: Shenghuo, dushu, xinzhi sanlian shudian, 2010. 
- - Z Zhu Xi zhexue yanjiu 朱喜哲學研究 (A study on Zhu Xi's philosophy). Beijing: Zhongguo shehui kexue chubanshe, 1988.

Cheng Gongrang 程恭讓. Jueze yu zhen wei zhijian: Ouyang Jingwu foxue sixiang tanwei 抉 擇於真偽之間——歐陽竟無佛學思想探微 (Choosing between the true and the false: an exploration of Ouyang Jingwu's Buddhist thought). Shanghai: Huadong shifan daxue chubanshe, 2000.

Cheng Hao 程影. “Shi ren pian” 諳仁篇 (On understanding “benevolence”). In “Mingdao xue'an” 明道學案 (The record of Mingdao), Zengbu Song Yuan xue'an 增補宋元學案 (The supplementary record of Song and Yuan scholars), eds. Huang Zongxi 黃宗羲 and others, vol. 13. Shanghai: Zhonghua shuju, 1927-1936.

Cheng Hao 程影 and Cheng Yi 程頣. Henan Chengshi yishu 河南程氏遺書 (Posthumous writings of Henan's Cheng Hao and Cheng Yi). In idem, ErCheng quanshu 二程全書 (The complete works of Cheng Hao and Cheng Yi). Shanghai: Zhonghua shuju, 19271936.

Cheng Yi 程頣. “Yi zhuan xu” 易傳序 (Preface to Cheng Yi's Annotation of the Book of Change). In idem, Zhouyi Chengshi zhuan 周易程氏傳 (Cheng Yi's annotation of the Book of Change). Beijing: Zhonghua shuju, 2011.

Chengguan 澄觀. Dafangguang fo Huayan jing suishu yanyi chao 大方廣佛華嚴經隨疏演 義鈔 (Sub-commentary and explanation of the meaning of the Huayan Sutra). In Taishō Tripițaka (q.v.), T36n1736.

Chuanshan quanshu 船山全書 (The complete works of Chuanshan), 16 vols. Changsha: Yuelu shushe, 1988-1996.

Ding Weixiang 丁爲祥. Xiong Shili xueshu sixiang pingzhuan 熊十力学术思想評傳 (A critical biography of Xiong Shili's academic thought). Beijing: Beijing tushuguan chubanshe, 1999.

Emperor Wu of Liang. “Li shenming cheng fo yi ji” 立神明成佛義記 (Record of the meaning of concsiousness' attaining Buddhahood). In Hongming ji 弘明集 (Collection on the propagation and elucidation [of Buddhism]), compiled by Sengyou 僧祐, Taishō Tripitaka (q.v.), T52n2102.

Epstein, Ronald. "The Transformation of Consciousness into Wisdom in the Chinese Consciousness-only School According to the Cheng Wei-shi Lun". Available at: http://online.sfsu.edu/rone/Buddhism/Yogacara/TRANSFORMATION\%200F\%20C ONSCIOUSNESS.htm, accessed August 5, 2018.

Fazang 法藏. Huayanjing yihai baimen 華嚴經義海百門 (One hundred categories of the many meanings in the Huayan Sutra). In Taishō Tripițaka (q.v.), T45n1875.

Feng Youlan 馮友蘭. Zhongguo zhexue jianshi 中國哲學簡史 (A brief history of Chinese philosophy). Beijing: Beijing daxue chubanshe, 1996.

Gao Zhennong 高振農. Dasheng qi xin lun jiaoshi 大乘起信論校釋 (Collation and 
annotation of the Treatise on Giving Rise to Faith in the Great Vehicle). Beijing: Zhonghua shuju, 1992.

Garfield, Jay. Engaging Buddhism: Why It Matters to Philosophy. New York: Oxford University Press, 2015.

Garfield, Jay L. and Jan Westerhoff. "Introduction: Madhyamaka and Yogācāra: Allies or Rivals?”. In Madhyamaka and Yogācāra: Allies or Rivals? (q.v.), eds. idem.

- - (eds.) Madhyamaka and Yogācāra: Allies or Rivals?. New York: Oxford University Press, 2015.

Gregory, Peter N. "The Vitality of Buddhism in the Sung". In Buddhism in the Sung, eds. idem and Daniel A. Getz, Jr. Honolulu: University of Hawai'I Press, 1999.

- - Tsung-mi and the Sinification of Buddhism. Princeton: Princeton University Press, 1991.

Guo Meihua 郭美華. Xiong Shili bentilun zhexue yanjiu 熊十力本體論哲學研究 (A study on Xiong Shili's ontological philosophy). Chengdu: Ba Shu shushe, 2004.

Guo Qiyong 郭齊勇. “Bianzhe houji” 編者後記 (Postscript from the editors). In Xiong Shili quanji (q.v.), vol. 1.

——. “Lun Xiong Shili de 'jinglun’ yu 'lianglun””論熊十力的“境論”與“量論” (A discussion of Xiong Shili's ontology and epistemology). In Xiong Shili quanji (q.v.), supplementary volume B.

一一. Tian di jian yige dushuren: Xiong Shili zhuan 天地間一個讀書人: 熊十力傳 (A scholar poised between heaven and earth: a biography of Xiong Shili). Shanghai: Shanghai wenyi chubanshe, 1994.

- - Xiong Shili zhexue yanjiu 熊十力哲學研究 (A study on Xiong Shili's philosophy). Beijing: Renmin chubanshe, 2011.

Halperin, Mark. Out of the Cloister: Literati Perspectives on Buddhism in Sung China, 9601279. Cambridge, Mass.: Harvard University Asia Centre, 2006.

Huang Lianzhong 黃連忠. “Huineng yu Wang Yangming benxin sixiang de shijian jinlu yu quanshi fangfa zhi lunxi” 惠能與王陽明本心思想的實踐進路與詮釋方法之論析 (A discussion and analysis of the practical approach to and the interpretative method for Huineng's and Wang Yangming's philosophy of "inherent mind"). Disanjie Zhongguo wenzhe zhi dangdai quanshi xueshu yantaohui huiqian lunwenji 第三屆中國文哲之當 代詮釋學術研討會會前論文集 (The proceedings published before the third Academic Conference on Contemporary Interpretation of Chinese Literature and Philosophy), Guoli Taibei daxue, 2007, pp. 287-305.

Huang Zongxi 黃宗羲. “Baisha xue’an, shang” 白沙學案上 (The record of Baisha, A). In idem, Ming ru xue'an 明儒學案 (The record of Ming scholars), vol.1. Beijing: Zhonghua shuju, 1985. 
Jiang Canteng 江燦騰. “Lü Cheng yu Xiong Shili lunxue hangao pingyi” 呂溦與熊十力論學 函稿評議 (A discussion on the scholarly correspondence between Lü Cheng and Xiong Shili). In Xiong Shili quanji (q.v.), supplementary volume A.

Jiang, Tao. Contexts and Dialogue: Yogācāra Buddhism and Modern Psychology on the Subliminal Mind. Honolulu: University of Hawaii Press, 2006.

Jiang Weiqiao 蔣維喬. Zhongguo fojiaoshi 中國佛教史 (Chinese Buddhist history). Changsha: Yuelu shushe, 2010.

Jiao Xun 焦循, Mengzi zhengyi 孟子正義 (The correct meaning of the Book of Mencius). Shanghai: Zhonghua shuju, 1927-1936.

Jing Haifeng 景海峰. Xiong Shili zhexue yanjiu 熊十力哲學研究 (A study on Xiong Shili's philosophy). Beijing: Beijing daxue chubanshe, 2010.

Jizang 吉藏. Dasheng xuan lun 大乘玄論 (On the profound meanings of Mahāyāna). In Taishō Tripițaka (q.v.), T45n1853.

Jorgensen, John. “Indra's Network: Zhang Taiyan's Sino-Japanese Personal Networks and the Rise of Yogācāra". In Transforming Consciousness: Yogācāra Thought in Modern China (q.v.), ed. John Makeham.

Juzan 巨贊. “Ping Xiong Shili suozhu shu” 評熊十力所著書 (Comments on Xiong Shili's books). In Xiong Shili quanji (q.v.), supplementary volume A.

Kantor, Hans-Rudolf. "Concepts of Reality in Chinese Mahāyāna Buddhism". In Chinese Metaphysics and Its Problems (q.v.), eds. Chenyang Li and Franklin Perkins.

Knoblock, John. Xunzi: A Translation and Study of the Complete Works. Stanford, Calif.: Stanford University Press, 1988-1994.

Lai, Whalen. "Emperor Wu of Liang on the Immortal Soul, Shen Pu Mieh". Journal of the American Oriental Society, vol. 101, no. 2, 1981, pp. 167-175.

Lai Yonghai 賴永海. “Foxing, benxin, liangzhi: Lu Wang xinxue yu foxue” 佛性 本心 良知 ——陸王心學與佛學 (Buddha nature, inherent mind, and innate moral knowledge: Lu Jiuyuan and Wang Yangming's philosophy of mind and Buddhist learning). Available at: http://www.gming.org/fjrw/jsrw/laiyonghai/40784.html, accessed August 5, 2018.

Li, Chenyang and Franklin Perkins (eds.) Chinese Metaphysics and Its Problems. Cambridge: Cambridge University Press, 2015.

Li Hua 李華. “Diao gu zhanchang wen” 吊古戰場文 (Lament at an ancient battle field). In Guwen guanzhi 古文觀止 (The finest of ancient prose), eds. Wu Chucai 吳楚材 and Wu Diaohou 吳調侯. Beijing: Zhongguo wenshi chubanshe, 2003.

Li Qingliang 李清良. “Lun Ma Yifu dui Xiong Shili Xin weishi lun zhi yingxiang” 論馬一浮 對熊十力《新唯識論》之影響 (A discussion of Ma Yifu's influence on Xiong Shili's New Treatise on the Uniqueness of Consciousness). Taiwan Dongya wenming yanjiu xuekan 
臺灣東亞文明研究學刊, vol. 7, issue. 1, June 2010, pp. 201-232.

——. “Ma Yifu dui Xiong Shili Xin weishi lun qianbanbu zhi yingxiang”馬一浮對熊十力《新 唯識論》前半部之影響 (Ma Yifu's influence on the first half of Xiong Shili's New Treatise on the Uniqueness of Consciousness). Hunan shifan daxue shehui kexue xuebao 湖南師範大學社會科學學報, issue 6, 2009, pp. 10-14.

Li Qingliang 李清良 and Guo Shengnan 郭勝男. “Xiong Shili Weishi lun zhuanzuo shijian kaobian” 熊十力《唯識論》撰作時間考辨 (An investigation into and clarification of the period of composition of Xiong Shili's Treatise on Yogācāra). Zhongguo wenhua yanjiu 中國文化研究, summer volume, 2009, pp. 38-44.

Li Qingliang 李清良 and Xu Yangnan 許揚男. “Ma Yifu dui Xiong Shili Zun wen lu zhi yiyi ji qi yingxiang”馬一浮對熊十力《尊聞錄》之異議及其影響 (Ma Yifu's objection to and its influence on Xiong Shili's Record of What Has been Respectfully Heard). Beijing daxue xиebao (zhexue shehui kexue ban) 北京大學學報 (哲學社會科學版), vol. 46, no. 2, March 2009, pp. 93-98.

Li Xiaochun 李曉春. “Wang Bi ‘ti yong lun’ shuzhen” 王顼 “體用論” 述真 (A discussion on Wang Bi's theory of ti-yong). Lanzhou daxue xuebao (shehui kexue ban) 蘭州大學 學報 (社會科學版), vol. 38, issue 4, July 2010, pp. 12-17.

Li Zehou 李澤厚. “Lüe lun Xiong Shili: lüe lun xiandai xinrujia zhiyi” 略論熊十力一一略論 現代新儒家之一 (A brief discussion of Xiong Shili: a brief discussion of the one of modern New Confucians). In Xiong Shili quanji (q.v.), supplementary volume B.

Liang Shuming 梁漱溟. “Jiu yuan jue yi lun” 究元決疑論 (A study on exploring the origin and resolving doubts). Dongfang zazhi 東方雜誌 (Eastern miscellany), vol. 13, issue 7, 1916, pp. 8-12.

——. Yi Xiong Shili xiansheng 憶熊十力先生 (Recollection of Mr. Xiong Shili). Taibei: Mingwen shuju, 1989.

Liao Minghuo 廖明活. Zhongguo foxing sixiang de xingcheng he kaizhan 中國佛性思想的 形成和開展 (The formation and development of thought on buddha-nature in China). Taibei: Wenjin chubanshe, 2008.

Lin, Chen-kuo (Lin Zhenguo 林鎮國). "Hsiung Shih-li's Hermeneutics of Self: Making a Confucian Identity in Buddhist Words”. NCCU Philosophical Journal, vol. 8, June 2002, pp. 69-90.

-—. "The Uncompromising Quest for Genuine Buddhism: Lü Cheng's Critique of Original Enlightenment". In Transforming Consciousness: Yogācāra Thought in Modern China (q.v.), ed. John Makeham.

Lin, Paul J. A Translation of Lao Tzu's Tao Te Ching and Wang Pi's Commentary. Ann Arbor: Center for Chinese Studies, The University of Michigan, 1977.

Lin Shirong 林世榮.Xiong Shiliyu “tiyong bu'er”lun 熊十力與 “體用不二” 論 (Xiong Shili and the theory of "the non-duality of Reality and Function"). Taibei: Wanjuanlou, 2008. 
Lin Zhenguo 林鎮國 (Lin, Chen-kuo). "Qi xin lun yu xiandai Dongya zhutixing zhexue: yi Neixueyuan yu xin rujia de zhenglun wei zhongxin de kaocha” 《起信論》與現代東亞 主體性哲學——以內學院與新儒家的爭論為中心的考察 (The Treatise on Giving Rise to Faith and the philosophy of subjectivity in modern East Asia: an investigation centred on the debates between the Institute of Inner Learning and new Confucians). Available at: https://www.academia.edu/34117398/_起信論_與現代東亞主體性哲學 _20170803.pdf, accessed August 5, 2018.

Liu, Jeeloo. "In Defense of Chinese Qi-naturalism". In Chinese Metaphysics and Its Problems (q.v.), eds. Chenyang Li and Franklin Perkins.

- - "Wang Fuzhi's Philosophy of Principle ( $\mathrm{Li}$ ) Inherent in Qi". In Dao Companion to NeoConfucian Philosophy (q.v.), ed. John Makeham.

Liu Junzu 劉君祖. Xiangjie Yijing Xici zhuan 詳解易經繫辭傳 (A detailed explanation of the "Appended Statements" in the Book of Change). Beijing: Xinxing chubanshe, 2011.

Liu Liangjian 劉梁劍. “Wang Bi lun ti yong guanxi” 王㢶論體用關係 (Wang Bi's discussions on the relationship between ti and yong). Bohai daxue xиebao (zhexue shehui kexue ban) 渤海大學學報 (哲學社會科學版), issue 2, 2004, pp. 4-7.

Liu Shipei 劉師培. “Zhelixue shi xu” 哲理學史序 (Prolegomena to a history of philosophy). Guocui xuebao 國粹學報, 3 (1905): 4a-4b.

Lou Yulie 樓宇烈. Wang Bi ji jiaoshi 王顼集校釋 (Collation and annotation of the collected writings of Wang Bi). Beijing: Zhonghua shuju, 1980.

Lu Jiuyuan～陸九波. “Yu Li Zai” 與李宰 (To Li Zai). In Xiangshan quanji (q.v.), vol. 11.

——. "Yulu” 語錄 (Sayings). In Xiangshan quanji (q.v.), vol. 34.

——. “Zashuo” 雜說 (Various discussions). In Xiangshan quanji (q.v.), vol. 22.

Lusthaus, Dan. Buddhist Phenomenology: A Philosophical Investigation of Yogācāra Buddhism and the Ch'eng Wei-shih lun. London: RoutledgeCurzon, 2002.

-—. "Lü Cheng, Epistemology, and Genuine Buddhism". In Transforming Consciousness: Yogācāra Thought in Modern China (q.v.), ed. John Makeham.

- - "The Two Truths (Sampvrti-satya and Paramārtha-satya) in Early Yogācāra". Journal of Buddhist Studies, vol. VII, 2010, pp. 101-152.

- - "Yogācāra School". In Encyclopedia of Buddhism, ed. Robert E. Buswell, Jr. New York: Thomson Gale, 2004, vol. 2, pp. 914-921.

Lynn, Richard John. The Classic of the Way and Virtue: A New Translation of the Tao-te ching of Laozi as Interpreted by Wang Bi. New York: Columbia University Press, 1999.

Ma Tianxiang 麻天祥. “Zhezhong kong you yu Yi de benxin bentilun” 折衷空、有於《易》 的本心本體論 (An ontology of the inherent mind that integrates the Emptiness and the Existence schools into the Book of Change). In Xuanpu lunxue xuji: Xiong Shili yu Zhongguo chuantong wenhua guoji xueshu yantaohui lunwenji (q.v.) 
Ma Yifu 馬一浮. Yulu leibian 語錄類編 (Classified compilation of the recorded sayings). In Ma Yifu ji (q.v.), vol. 3.

Ma Yifu ji 馬一浮集 (Collections of Ma Yifu), 3 vols. Hangzhou: Zhejiang guji chubanshe, 1996.

Makeham, John. "Chinese Philosophy's Hybrid Identity". In Why Traditional Chinese Philosophy Still Matters: The Relevance of Ancient Wisdom for the Global Age, ed. Ming Dong Gu. London: Routledge, 2018.

_- (ed.) Dao Companion to Neo-Confucian Philosophy. New York: Springer, 2010.

- - "Interpretations of Ālambana-parìkșā in the Early Days of the Peking University Philosophy Department". Forthcoming.

-—. "Introduction". In The Buddhist Roots of Zhu Xi's Philosophical Thought (q.v.), ed. idem.

-—. "Introduction". In Transforming Consciousness: Yogācāra Thought in Modern China (q.v.), ed. idem.

-—. Lost Soul: "Confucianism" in Contemporary Chinese Academic Discourse. Cambridge, Mass.: Harvard University Asia Centre, 2008.

- - " Monism and the Problem of the Ignorance and Badness in Chinese Buddhism and Zhu Xi's Neo-Confucianism". In The Buddhist Roots of Zhu Xi's Philosophical Thought (q.v.), ed. idem.

- - (trans. and annot.) New Treatise on the Uniqueness of Consciousness. New Haven \& London: Yale University Press, 2015.

- - (ed.) The Buddhist Roots of Zhu Xi's Philosophical Thought. New York: Oxford University Press, 2018.

- - "The Significance of Xiong Shili's Interpretation of Dignāga's Ālambana-parīkșā (Investigation of the Object)". Journal of Chinese Philosophy, vol. 40, no. supplement S1, December 2013, pp. 205-225.

- - (ed.) Transforming Consciousness: Yogācāra Thought in Modern China. New York: Oxford University Press, 2014.

- - Transmitters and Creators: Chinese Commentators and Commentaries on the Analects. Cambridge, Mass.: Harvard University Asia Centre, 2003.

- - . "Xiong Shili on Why Reality Cannot be Sought Independent of Phenomena". Sophia, vol. 56, issue 3, September 2017, pp. 501-517.

- - "Xiong Shili's Critique of Yogācāra Thought in the Context of His Constructive Philosophy". In Transforming Consciousness: Yogācāra Thought in Modern China (q.v.), ed. idem.

- - . "Xiong Shili's Understanding of the Relationship between the Ontological and the Phenomenal". In Chinese Metaphysics and Its Problems (q.v.), eds. Chenyang Li and 
Franklin Perkins.

- - "Zhang Taiyan, Yogācāra Buddhism, and Chinese Philosophy". In Learning to Emulate the Wise: The Genesis of Chinese Philosophy as an Academic Discipline in TwentiethCentury China, ed. idem. Hong Kong: Chinese University Press, 2012.

Mao Yufan 茅宇凡. “Weishixue zizheng lilun zhi yanjiu: yi Cheng weishi lun wei zhongxin” 唯識學 “自證” (svasamvitti) 理論之研究——以《成唯識論》爲中心 (A study on the Yogācāra theory of self-verification [svasamvitti]: with a focus on the Treatise Demonstrating Nothing but Consciousness). Zhonghua foxue yanjiu 中華佛學研究, no. 11, 2010, pp. 141-169.

Mengzi 孟子. “Gaozi zhangju, shang” 告子章句上 (The chapter of “Gaozi”, A). In Jiao Xun, Mengzi zhengyi (q.v.), vol. 23.

-—. “Jin xin zhangju, shang” 盡心章句上 (The chapter of “Exhausting the Mind", A). In Jiao Xun, Mengzi zhengyi (q.v.), vol. 26.

Mou Zongsan 牟宗三. “Fojia ti yong yi zhi hengding” 佛家體用義之衡定 (A judgment of the meaning of ti-yong in Buddhism). In idem, Xinti yu xingti 心體與性體 (Reality of the mind and of human nature). Taibei: Zhengzhong shuju, 1968-1969, vol. 1.

Muller, A. Charles (ed.) Digital Dictionary of Buddhism. Available at: http://www.buddhismdict.net/ddb/

- - "The Emergence of Essence-Function (ti-yong) 體用 Hermeneutics in the Sinification of Indic Buddhism: An Overview". Critical Review of Buddhist Studies, no. 19, June 2016, pp. 111-152.

Murthy, Viren. The Political Philosophy of Zhang Taiyan: The Resistance of Consciousness. Leiden: Brill, 2011.

Ng Yu-kwan (Wu Rujun 吳汝鈞). “Xiong Shili's Metaphysical Theory about the Nonseparability of Substance and Function". In New Confucianism: A Critical Examination, ed. John Makeham. New York: Palgrave Macmillan, 2003.

Ouyang Jingwu 歐陽竟無. “Ouyang Jingwu xiansheng yanjiang” 歐陽竟無先生演講 (Mr. Ouyang Jingwu's speeches), recorded by Nie Ougeng 聶耦耕 and edited by Lü Cheng 呂澂. In Weishi jueze tan 唯識抉擇談 (Decisive talks on Yogācāra). Nanjing: Zhina neixue yuan, 1922.

——. “Weishi jueze tan” 唯識抉擇談 (Decisive talks on Yogācāra). In Ouyang Jian xuanji 歐陽漸選集 (Selected works of Ouyang Jingwu), Xiandai foxue daxi (q.v.), vol. 51.

Peng Yaoguang 彭耀光. “Cong 'ti yong yiyuan, xian wei wujian' kan Cheng Yi lixue de jingshen” 從 “體用一源, 顯微無間” 看程頣理學的精神 (To see the spirit of Cheng Yi's learning of principle from his "Reality and Function are a single source; there is no gap between the apparent and the subtle”). Dongyue luncong 東岳論叢, vol. 32, no. 8, August 2011, pp. 45-49.

Platt, Stephen R. Provincial Patriots: The Hunanese and Modern China. Cambridge, Mass.: 
Harvard University Press, 2007.

Powers, John. "Yogācāra: Indian Buddhist Origins". In Transforming Consciousness: Yogācāra Thought in Modern China (q.v.), ed. John Makeham.

Qian Mu 錢穆. Song Ming lixue gaishu 宋明理學概述 (An overview of Song-Ming NeoConfucianism). Beijing: Jiuzhou chubanshe, 2011.

——. “Yi Shili, Xiyu zhuyou” 憶十力、錫予諸友 (Recollection of various friends like Shili and Xiyu). In Xuanpu lunxue ji: Xiong Shili shengping yu xueshu 玄戋論學集: 熊十力 生平與學術 (Collected works of academic discussions in the "treasured garden": Xiong Shili's life and learning). Beijing: Shenghuo, dushu, xinzhi sanlian shudian, 1990.

Rošker, Jana S. "Modern Confucian Synthesis of Qualitative and Quantitative Knowledge: Xiong Shili 熊十力”. Journal of Chinese Philosophy, vol. 36, no. 3, 2009, pp. 376-390.

- - " "The Philosophical Sinification of Modernity and the Modern Confucian Paradigm of Immanent Transcendence (內在超越性)”. Asian Studies, vol. 2, no. 1, 2014, pp. 67-81.

- - Traditional Chinese Philosophy and the Paradigm of Structure ( $\mathrm{Li}$ 理). Newcastle upon Tyne: Cambridge Scholars Publishing, 2012.

Rudolf, Wagner G. A Chinese Reading of the Daodejing: Wang Bi's Commentary on the Laozi with Critical Text and Translation. Albany: State University of New York Press, 2003.

Rump, Ariane (in collaboration with Wing-tsit Chan). Commentary on the Lao Tzu by Wang Pi. Honolulu: The University Press of Hawaii, 1979.

Sengzhao 僧肇. “Bore wuzhi lun” 般若無知論 (Wisdom knows nothing). In Zhao lun (q.v.)

-—. "Wu bu qian lun” 物不遷論 (Things do not shift). In Zhao lun (q.v.)

——.Zhao lun 肇論 (Essays by Sengzhao). In Taishō Tripițaka (q.v.), T45n1858.

Shen, Vincent. “Being and Events: Huayan Buddhism's Concept of Event and Whitehead's Ontological Principle". In Chinese Metaphysics and Its Problems (q.v.), eds. Chenyang Li and Franklin Perkins.

Shi Cun 石村. Yinming shu yao 因明述要 (Summary of Buddhist logic). Beijing: Zhonghua shuju, 1981.

Shi Zhonglian 施忠連. “Chuantong de zhexue huayu; zui xin de zhexue guannian: lun Xiong Shili de chuangzao zhexue” 傳統的哲學話語 最新的哲學觀念一一論熊十力的創造 哲學 (Traditional philosophical utterance; the newest philosophical ideas: a discussion of Xiong Shili's creative philosophy). In Xuanpu lunxue xuji: Xiong Shili yu Zhongguo chuantong wenhua guoji xueshu yantaohui lunwenji (q.v.)

Shimada, Kenji 島田虔次. Xiong Shili yu xin rujia zhexue 熊十力與新儒家哲學 (Xiong Shili and new Confucian philosophy), trans. Xu Shuisheng 徐水生. Taibei: Mingwen shuju, 1992.

- - Zhongguo sixiangshi yanjiu 中國思想史研究 (A study on Chinese intellectual 
history), trans. Deng Hong 鄧紅. Shanghai: Shanghai guji chubanshe, 2009.

Shisan jing zhushu 十三經注疏 (The thirteen classics with annotations and subcommentaries), compiled by Ruan Yuan 阮元. Taibei: Yiwen yinshuguan, 1981.

“Shuogua” 說卦 (Explanations of hexagrams). In Zhouyi zhengyi (q.v.)

Song Xuehai 宋學海 and Wang Hui 王輝. Yijing 易經 (The Book of Change). Kunming: Yunnan renmin chubanshe, 2011.

Song Zhiming 宋志明. Xiong Shili pingzhuan 熊十力評傳 (A critical biography of Xiong Shili). Nanchang: Baihuazhou wenyi chubanshe, 2010.

Sponberg, Alan. "The Trisvabhāva Doctrine in India \& China: A Study of Three Exegetical Models". Bulletin of Institute of Buddhist Cultural Studies, Ryukoku University, Kyoto, no. 21, 1982, pp. 97-119.

Tagawa, Shun'ei. Living Yogācāra: An Introduction to Consciousness-only Buddhism, translated with an introduction by Charles Muller. Boston: Wisdom Publications, 2009.

Taishō Tripițaka (Taishō revised Tripițaka), Taishō shinshū dai zōkyō 大正新脩大藏經 (Taishō revised Tripițaka), Tokyo: Taishō Issaikyō Kankōkai, 1924-1935 as found in the CBETA corpus of Buddhist texts, Chinese Buddhist Electronic Text Association (CBETA). Available at: http://www.cbeta.org/

Taixu 太虛. “Fofa zong jueze tan” 佛法總抉擇談 (A discussion on the overall choices of the Buddha's teachings). In Taixu dashi quanshu 太虛大師全書 (The complete works of Master Taixu). Taibei: Taixu dashi quanshu yingyin weiyuanhui, 1998, vol. 9.

- - "Lüe ping Xin weishi lun" 略評新唯識論 (A brief review of New Treatise on the Uniqueness of Consciousness). In Xiong Shili quanji (q.v.), supplementary volume A.

Tan, Sor-hoon. “Contemporary Neo-Confucian Philosophy”. In History of Chinese Philosophy, ed. Bo Mou. London: Routledge, 2009.

Tang Yongtong 湯用粀. Han Wei LiangJin NanBeichao fojiao shi 漢魏兩晉南北朝佛教史 (Buddhist history during the Han, Wei, the two Jins, and the Southern and Northern dynasties). Banqiao shi: Luotuo chubanshe, 1987.

- - Sui Tang fojiaoshi gao 隋唐佛教史稿 (A manuscript on the Buddhist history of the Sui-Tang period). Beijing: Zhonghua shuju, 1982.

Tien, David W. "Metaphysics and the Basis of Morality in the Philosophy of Wang Yangming". In Dao Companion to Neo-Confucian Philosophy (q.v.), ed. John Makeham.

Vasubandhu. Triṃśikā (Weishi sanshi lun song 唯識三十論頌; Thirty verses), trans. Xuanzang 玄牀. In Taishō Tripițaka (q.v.), T31n1586.

Wang Enyang 王恩洋. “Dasheng qi xin lun liaojian” 大乘起信論料簡 (An explanation of the Treatise on Giving Rise to Faith in the Great Vehicle). In Wang Enyang xuanji 王恩 洋選集 (Selected writings of Wang Enyang), Xiandai foxue daxi (q.v.), vol. 51. 
Wang Fuzhi 王夫之. Zhangzi Zheng meng zhu 張子正蒙注 (An annotation of Zhang Zai's Correction of Youthful Ignorance). In Chuanshan quanshu (q.v.), vol. 12.

- - Zhouyi waizhuan 周易外傳 (An extended interpretation of the Book of Change). In Chuanshan quanshu (q.v.), vol. 1.

Wang, Robin R. "Yinyang Narrative of Reality: Chinese Metaphysical Thinking". In Chinese Metaphysics and Its Problems (q.v.), eds. Chenyang Li and Franklin Perkins.

Wang, Robin R. and Ding Weixiang 丁爲祥. “Zhang Zai's Theory of Vital Energy”. In Dao Companion to Neo-Confucian Philosophy (q.v.), ed. John Makeham.

Wang Ruhua 王汝華. Xiandai rujia sansheng: Liang Shuming, Xiong Shili, Ma Yifu de jiaoyi jishi 現代儒家三聖：梁漱溟、熊十力、馬一浮的交誼紀實 (The three modern Confucian sages: a record of the associations between Liang Shuming, Xiong Shili, and Ma Yifu). Taibei: Xiuwei zixun keji gufen youxian gongsi, 2012.

Wang Shouchang 王守常. “Ershi shiji ru fo zhi zheng: Xiong Shili yu Liu Dingquan de zhenglun” 二十世紀儒佛之爭一一熊十力與劉定權的爭論 (The battles between Confucianism and Buddhism in the twentieth century: the debate between Xiong Shili and Liu Dingquan). In Xiong Shili quanji (q.v.), supplementary volume A.

Wang Yangming 王陽明. Chuan xi lu 傳習錄 (Record on teaching and learning). Taibei: Zhengzhong shuju, 1954.

-—. “Daxue wen” 《大學》問 (Questions about the Great Learning). In Wang Yangming quanji 王陽明全集 (Complete works of Wang Yangming). Shanghai: Shanghai guji chubanshe, 1992, vol. B.

Wei Zhengtong 韋政通. Zhongguo zhexue cidian daquan 中國哲學辭典大全 (A complete dictionary of Chinese philosophy). Beijing: Shijie tushu chuban gongsi, 1989.

Wu Rujun 吳汝鈞 (Ng Yu-kwan). Fojiao sixiang dacidian 佛教思想大辭典 (Dictionary of Buddhist thought). Taibei: Taiwan shangwu yinshuguan, 1992.

——. Weishi xianxiangxue: Shiqin yu Hufa 唯識現象學: 世親與護法 (Yogācāra phenomenology: Vasubandhu and Dharmapāla). Taibei: Taiwan xuesheng shuju, 2002.

- - . "Weishizong zhuan shi cheng zhi lilun zhi yanjiu” 唯識宗轉識成智理論之研究 (A study on the Yogācāra theory of "the transformation of consciousness into wisdom"). In idem, Fojiao de gainian yu fangfa 佛教的概念與方法 (On Buddhist concepts and methods). Taibei: Taiwan shangwu yinshuguan, 1988.

Wu Yifeng 烏以風. “Wen xue siji” 問學私記 (Private record of consulting about learning). In Ma Yifu ji (q.v.), vol. 3.

Xiandai foxue daxi 現代佛學大系 (Modern Buddhist studies series), 60 vols. Xindian: Mile chubanshe, 1984.

Xiang Shiling 向世陵. Li qi xing xin zhijian: Song Ming lixue de fenxi yu sixi 理氣性心之間 - 一宋明理學的分系與四系 (Between principle, vital stuff, human nature, and the 
mind: the division and the four systems of Song-Ming Neo-Confucianism). Beijing: Renmin chubanshe, 2008.

Xiangshan quanji 象山全集 (The complete works of Xiangshan), 36 vols. Shanghai: Zhonghua shuju, 1927-1936.

“Xici" 繫辭 (Appended statements). In Zhouyi zhengyi (q.v.)

Xiong Shili 熊十力. “Chen Baisha xiansheng jinian” 陳白沙先生紀念 (In commemoration of Mr. Chen Baisha). In Shili yuyao chuxu (q.v.)

——. “Chuanshanxue ziji” 船山學自記 (Personal note on Wang Chuanshan's learning). In Xin $\operatorname{shu}$ (q.v.)

- - “Da He Zixin shu” 答何自新書 (A letter of reply to He Zixin). In Xiong Shili quanji (q.v.), vol. 8.

-—. “Da moujun” 答某君 (Reply to someone). In Shili lunxue yu jilüe (q.v.)

-—. “Da youren” 答友人 (Reply to a friend). In Zun wen lu (q.v.)

——. “Da Zhang Dongsun” 答張東蓀 (Reply to Zhang Dongsun). In Shili lunxue yu jilüe (q.v.)

- - Fojia mingxiang tongshi 佛家名相通釋 (Complete explanation of Buddhist terms). In Xiong Shili quanji (q.v.), vol. 2.

——. “Fu Wu Guanyin (kuichou)” 復吳貫因（癸丑） (Reply to Wu Guanyin [1913]). In Xin shu (q.v.)

——. “Fu Zhangjun” 復張君 (Reply to Mr. Zhang). In Xin shu (q.v.)

——. “He Zixin zhuan” 何自新傳 (A biography of He Zixin). In Shili yuyao (q.v.)

- - “Ji Liangjun shuo Lupang boshi zhi xueshuo” 記梁君說魯滂博士之學說 (Record of Mr. Liang's discussions on Doctor Le Bon's doctrines). In Xin shu (q.v.)

——. “Jian'an suibi” 健庵隨筆 (An essay in Jian'an). In Xiong Shili quanji (q.v.), vol. 8.

- - “Jian'an suibi (xu)” 健庵隨筆 (續) (An essay in Jian'an [continuation]). In Xiong Shili quanji (q.v.), vol. 8.

——. “Jiangci” 講詞 (Speech). In Shili lunxue yu jilüe (q.v.)

——. “Jinian Beijing daxue wushinian bing wei Lin Zaiping zhugu” 紀念北京大學五十年並 爲林宰平祝嘏 (In commemoration of the fifty years of Peking University and also in celebration of Lin Zaiping's birthday). In Shili yuyao chuxu (q.v.)

——. “Li Dixuan jiyu” 黎滌玄記語（Record by Li Dixuan). In Shili yuyao (q.v.)

- - . "Po 'Po Xin weishi lun'” 破《破新唯識論》 (Refutation of the “Refutation of the New Treatise on the Uniqueness of Consciousness"). In Xiong Shili quanji (q.v.), vol. 2.

- - Shili lunxue yu jilüe 十力論學語輯略 (Edited collection of Shili's discussions of learning). In Xiong Shili quanji (q.v.), vol. 2. 
——. Shili yuyao 十力語要 (Selected letters and talks of Xiong Shili). In Xiong Shili quanji (q.v.), vol. 4.

- - Shili yиyaо chuхи 十力語要初續 (The first sequel to Selected Letters and Talks of Xiong Shili). In Xiong Shili quanji (q.v.), vol. 5.

- - “Tongxin (Xiong Zizhen yu Luo Zhixi)” 通信 (熊子真與羅志希) (Correspondence between Xiong Shili and Luo Zhixi). In Xiong Shili quanji (q.v.), vol. 8.

——. “Wang Han zhuan” 王漢傳 (A biography of Wang Han). In Shili yuyao (q.v.)

——. Weishi lun 唯識論 (Treatise on Yogācāra). In Xiong Shili quanji (q.v.), vol. 1.

- - Weishixue gailun (1926) 唯識學概論 (一九二六年) (A general account of Yogācāra learning [published in 1926]). In Xiong Shili quanji (q.v.), vol. 1.

- - Weishixue gailun (1923) 唯識學概論 (一九二三年) (A general account of Yogācāra learning [published in 1923]). In Xiong Shili quanji (q.v.), vol. 1.

——. “Wenjin xuehui qi” 問津學會啓 (A letter to the Society for Making Inquiries). In Xin shu (q.v.)

——.Xin shu 心書 (Book of mind). In Xiong Shili quanji (q.v.), vol. 1.

- - Xin weishi lun (shanding ben, 1953) 新唯識論 (刪定本, 一九五三年) (New treatise on the uniqueness of consciousness [expurgated and finalised version, published in 1953]). In Xiong Shili quanji (q.v.), vol. 6.

- - Xin weishi lun (wenyanwen ben, 1932) 新唯識論 (文言文本, 一九三二年) (New treatise on the uniqueness of consciousness [literary version, published in 1932]). In Xiong Shili quanji (q.v.), vol. 2.

- - Xin weishi lun (yutiwen ben, 1944) 新唯識論 (語體文本, 一九四四年) (New treatise on the uniqueness of consciousness [vernacular version, published in 1944]). In Xiong Shili quanji (q.v.), vol. 3.

-—. "Yi jing lu xuyan” 翊經錄緒言 (An introduction to The Record of Assisting the Classics). In Xiong Shili quanji (q.v.), vol. 8.

——. “Yu Laisheng” 與賴生 (To Mr. Lai). In Shili lunxue yu jilüe (q.v.)

——. "Yu youren" 與友人 (To a friend). In Shili lunxue yu jilüe (q.v.)

——. “Yu Zhang Jitong” 與張季同 (To Zhang Jitong). In Shili lunxue yu jilüe (q.v.)

——. "Yu Zhang Suwu" 與張素武 (To Zhang Suwu). In Xin shu (q.v.)

——. "Yu zhi Feiwu” 與侄非武 (To my nephew Feiwu). In Zun wen lu (q.v.)

-—. “Zhang Chunyi cungao xu” 張純一存葈序 (Preface to Zhang Chunyi's Manuscripts). In Xin shu (q.v.)

-—. “Zhang Yichen Li Zhuan yishi” 張翊辰李專遺事 (The story of Zhang Yichen and Li Zhuan). In Xin shu (q.v.) 
-—. "Zheng ren xuehui qi” 證人學會啓 (A letter to the Academy for Demonstrating Humanity). In Xiong Shili quanji (q.v.), vol. 8.

- - . “Zhi Lü Cheng bing fu yu Liang Shuming lun Yihuang dashi” 致呂澂並附與梁漱溟論 宜黃大師 (To Lü Cheng, enclosed with my “Discussion with Liang Shuming about the Venerable Master from Yihuang"). In Xiong Shili quanji (q.v.), vol. 8.

_- Zun wen lu 尊聞錄 (Record of what has been respectfully heard). In Xiong Shili quanji (q.v.), vol. 1.

Xiong Shili quanji 熊十力全集 (The complete writings of Xiong Shili), 10 vols. Wuhan: Hubei jiaoyu chubanshe, 2001.

Хиапри lunxue xuji: Xiong Shili yu Zhongguo chuantong wenhua guoji хиеshu yantaohui lunwenji 玄戋論學續集：熊十力與中國傳統文化國際學術研討會論文集 (A sequel to Collected Works of Academic Discussions in the "Treasured Garden": the proceedings of the International Symposium on Xiong Shili and Traditional Chinese Culture), ed. Wuhan daxue Zhongguo chuantong wenhua yanjiu zhongxin 武漢大學中國傳統文化 研究中心. Wuhan: Hubei jiaoyu chubanshe, 2003.

Xuanzang 玄牀. Cheng weishi lun 成唯識論 (Treatise demonstrating nothing but consciousness). In Taishō Tripitaka (q.v.), T31n1585.

——. “Xie Taizong Wen Huangdi zhi Sanzang shengjiao xubiao” 謝太宗文皇帝製三藏聖教 序表 (Memorial to thank Emperor Taizong, whose posthumous title is wen, for writing a preface to the holy teaching of Tripițaka). In Si Shamen Xuanzang shangbiao ji 寺沙 門玄牀上表記 (Record of memorials presented by Monk Xuanzang), Taishō Tripitaka (q.v.), T52n2119.

Xunzi 荀子. “Fu guo pian” 富國篇 (On enriching the country). In Wang Xianqian 王先謙, Xunzi jijie 荀子集解 (The variorum commentary on Xunzi). Beijing: Zhonghua shuju, 1988.

Yan Fu 嚴復. Tian yan lun 天演論 (The theory of evolution). Beijing: Shangwu yinshuguan, 1981.

Yao, Zhihua. "Yogācāra Critiques of the Two Truths". In A Distant Mirror: Articulating Indic Ideas in Sixth and Seventh Century Chinese Buddhism, eds. Chen-kuo Lin and Michael Radich. Hamburg: Hamburg University Press, 2014.

Ye Xian'en 葉賢恩. Xiong Shili zhuan 熊十力傳 (A biography of Xiong Shili). Wuhan: Hubei renmin chubanshe, 2010.

Yongming Yanshou 永明延壽. Zong jing $l u$ 宗鏡錄 (Records of the mirror of axioms). In Taishō Tripițaka (q.v.), T48n2016.

Yu, Jiyuan. "Xiong Shili's Metaphysics of Virtue". In Contemporary Chinese Philosophy, eds. Chung-ying Cheng and Nicholas Bunnin. Malden, Mass.: Blackwell Publishers, 2002.

Yu Lingbo 于凌波.Jianming Cheng weishi lun baihua jiangji 簡明成唯諳論白話講記 (A concise and vernacular explanation of the Treatise Demonstrating Nothing but 
Consciousness). Available at:

http://www.book853.com/wap.aspx?nid=1551\&p=1\&cp=5\&cid=91, accessed August 5, 2018.

- - Weishi sanlun jin quan 唯識三論今詮 (A contemporary interpretation of the three Yogācāra treatises). Taibei: Dongda tushu gongsi, 2008.

Yuan Weijie 袁偉傑. “Ti yong guannian laiyuan zhi zhengyi kao” 體用觀念來源之爭議考 (An inquiry into the dispute on the source of the ti-yong idea). Shiyi 史繹, issue 36, 2011, pp. 1-29.

Zhang Dainian 張岱年. Key Concepts in Chinese Philosophy, trans. and ed. Edmund Ryden. Beijing: Foreign Languages Press, 2002.

- - Zhongguo gudian zhexue gainian fanchou yaolun 中國古典哲學概念範疇要論 (On the key concepts and categories in classical Chinese philosophy). Beijing: Zhongguo shehui kexue chubanshe, 1989.

- - Zhongguo zhexue dagang 中國哲學大綱 (An outline of Chinese philosophy). Nanjing: Jiangsu jiaoyu chubanshe, 2005.

Zhang Liwen 張立文. Zhongguo zhexue fanchou fazhanshi (tiandao pian) 中國哲學範疇發 展史（天道篇） (The developmental history of Chinese philosophical categories [on the way of heaven]). Beijing: Zhongguo renmin daxue chubanshe, 1988.

Zhang Taiyan 章太炎. “Jianli zongiiao lun” 建立宗教論 (On founding a religion). In Zhang Taiyan quanji (q.v.), vol. 4.

- - Qi wu lun shi dingben 齊物論釋定本 (Definitive edition of explanation of "Discourse on Making All Things Equal"). In Zhang Taiyan quanji (q.v.), vol. 6.

Zhang Taiyan quanji 章太炎全集 (The complete works of Zhang Taiyan), 6 vols. Shanghai: Shanghai renmin chubanshe, 1985.

Zhang Xiaojian 張曉劍. “Huayan zong ti yong lun ji qi dui lixue ti yong lun de kaiqi” 華嚴 宗體用論及其對理學體用論的開啓 (The thought of Reality and Function of the Huayan school and its inspiration on that of the School of Principle). Xueshu yuekan 學 術月刊, vol. 40, no. 10, October 2008, pp. 56-63.

Zhang Zai 張載. Hengqu Yi shuo 橫渠易說 (Hengqu's explanation of the Book of Change). In Zhang Zai ji (q.v.)

- - Zheng meng 正蒙 (Correction of youthful ignorance). In Zhang Zai ji (q.v.)

Zhang Zai ji 張載集（Collected works of Zhang Zai). Beijing: Zhonghua shuju, 1978.

Zhou Dunyi 周敦頣. Zhouzi tong shu 周子通書 (Zhou Dunyi's book on penetrating the Book of Change). Shanghai: Zhonghua shuju, 1927-1936.

Zhouyi zhengyi 周易正義 (The correct meaning of the Book of Change), eds. Kong Yingda 孔穎達 and others. In Shisan jing zhushu (q.v.), vol. 1. 
Zhu Bokun 朱伯㞺. Yixue zhexueshi 易學哲學史 (The philosophical history of the learning of the Book of Change). Beijing: Huaxia chubanshe, 1995.

Zhu Xi 朱喜. “Da He Shujing” 答何叔京 (Reply to He Shujing). In Zhuzi daquan (q.v.), vol. 40.

- - "Da Wang Shangshu” 答汪尚書 (Reply to Minister Wang). In Zhuzi daquan (q.v.), vol. 30.

Zhuzi daquan 朱子大全 (The complete works of Zhu Xi). Shanghai: Zhonghua shuju, 19271936.

Ziporyn, Brook A. Beyond Oneness and Difference: Li 理 and Coherence in Chinese Buddhist Thought and Its Antecedents. Albany: State University of New York Press, 2013.

——. "The Ti-Yong 體用 Model and Its Discontents: Models of Ambiguous Priority in Chinese Buddhism and Zhu Xi's Neo-Confucianism". In The Buddhist Roots of Zhu Xi's Philosophical Thought (q.v.), ed. John Makeham. 